

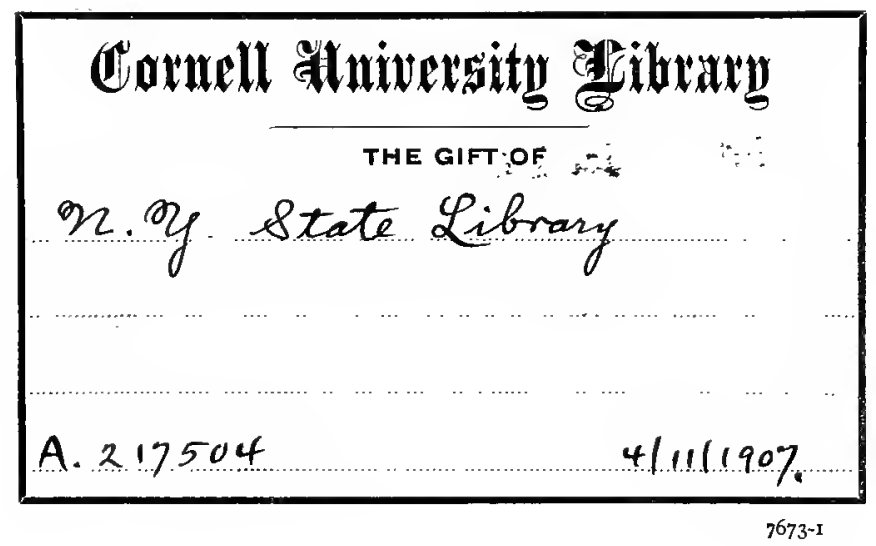




\section{QE 851.E13}

Devonic fishes of the New York formation

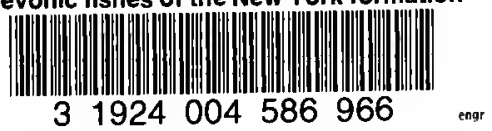

3 1924004586966 


\section{Cornell University Library}

The original of this book is in the Cornell University Library.

There are no known copyright restrictions in the United States on the use of the text.

http://www.archive.org/details/cu31924004586966 




\section{New York State Museum}

John M. Clarke, Director

\section{Memoir Io}

\section{DEVONIC FISHES OF THE NEW YORK FORMATIONS}

BY

CHARLES R. EASTMAN

\begin{tabular}{|c|c|c|c|c|}
\hline & PAGB & & & PAGB \\
\hline Introduction & 7 & Summary and conclusions & - & I 73 \\
\hline $\begin{array}{l}\text { Conspectus of species, arranged ac- } \\
\text { cording to their geological occur- } \\
\text { rence - }- \text { - }_{-}-\mathrm{C}_{-}\end{array}$ & I 2 & $\begin{array}{l}\text { Zoological conclusions } \\
\text { Geological conclusions with } \\
\text { on the distribution of }\end{array}$ & remarks & 178 \\
\hline Tabular key to systematic descriptions & 23 & fishes - & & 183 \\
\hline Systematic account of Devonic fishes, & & Explanation of plates & - & I95 \\
\hline principally from New York and & & Index - & - & 225 \\
\hline Pennsylvania - & 24 & & & \\
\hline
\end{tabular}

\section{ALBANY}

NEW YORK STATE EDUCATION DEPARTMENT

1907

T 


\section{STATE OF NEW YORK \\ EDUCATION DEPARTMENT \\ Regents of the University \\ With years when terms expire}

I9I3 Whitelaw Reid M.A. LL.D. Chancellor - - - New York

igi7 St Claik McKelway M.A. LL.D. Vice Chancellor - Brooklyn

1908 Daxiel Beach Ph.D. LL.D. - - - - - - Watkins

I9I4 Pliny T. Sexton LL.B. Ll.D. - - - - Palmyra

igi2 T. Guilford Smith M.A. C.E. LL.D. - - - Buffalo

I9I8 William Nottingham M.A. Ph.D. Ll.D. - Syracuse

igio Charles A. Gardiner Ph.D. L.H.D. LL.D. D.C.L. New York

I915 Albert Vander Veer M.D. M.A. Ph.D. Ll.D. - Albany

igi I Edward Lauterbach M.A. LL.D. - - New York

1909 Eugene A. Philbin Ll.B. LL.D. - - - - New York

igi6 Lucian L. Shedden LL.B. - - - - - - - Plattsburg

Commissioner of Education

Andrew S. Draper LL.B. LL.D.

Assistant Commissioners

Howard J. Rogers M.A. LL.D. First Assistant

Edward J. Goodwin Lit.D. L.H.D. Second Assistant

Augustus S. Downing M.A. Pd.D. LL.D. Third Assistant

Secretary to the Commissioner

Harlan H. Horner B.A.

Director of State Library

Edwin H. Anderson M.A.

Director of Science and State Museum

John M. Clarke Ph.D. LL.D.

Chiefs of Divisions

Accounts, William Mason

Attendance, James D. Sullivan

Educational Extension, William R. Eastman M.A. M.L.S.

Examinations, Charles F. Wheelock B.S. LL.D.

Inspections, Frant H. Wood M.A.

Law, Thomas E. Finegan M.A.

School Libraries, Charles E. Fitcir L.H.D.

Statistics, Hiram C. Case

Tisual Instruction, DeLaxiey M. Eldis 


\section{New York State Education Department}

Hon. Andrew S. Draper LL.D.

Science Division, May 26, 1906

Commissioner of Education

MY DEAR SIR: I transmit herewith, with the recommendation for publication as a memoir of the State Museum, a monograph on the Devonic fishes of New York which has been prepared at my urgent request by $\mathrm{Dr}$ Charles R. Eastman.

I take especial satisfaction in presenting this important document as it is the result of the first attempt made to acquire a full knowledge of the fishes buried in our geological formations. In the previous study of New York paleontology this interesting field has been largely overlooked and this work is the first of its kind prepared for publication in any of our states.

Very respectfully

John M. Clatrie

Dircctor and State Paleontologist

Approved for publication, June 6, 1906

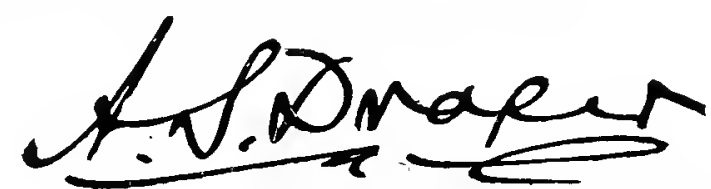

Commissioner of Education 



\section{DEVONIC FISHES OF THE NEW YORK FORMATIONS}

\section{INTRODUCTION}

Since the publication by Professor John Strong Newberry, in 1889 , of an extensive Monograph on the Palaeozoic Fishes of North America ${ }^{1}$ our knowledge of this group of fossil organisms has been vastly increased. Devonic fishes, in particular, have furnished important information concerning the organization and relations of primitive chordates, besides throwing much new light on the early history of fishes and fishlike vertebrates. If incertitude still exists regarding the larger problems of ancestry, we have at least progressed further than any one would have deemed possible a generation ago, and have been able to determine with reasonable accuracy not only the progressive stages of evolution passed through by various groups, but also the manner in which certain fundamental structures, such as the paired limbs, dentition, dermal covering, etc. arose. With increasing wealth of material, some of it magnificently preserved, we have become almost as well acquainted with the structure of certain genera, sometimes even including the soft tissues, like the muscle fibers of Cladoselache, as with the corresponding parts of modern fishes.

All this notable advance has been made within comparatively few years, and the results of modern paleontological research are scattered throughout a wide series of publications in this country and abroad, not all of them readily accessible. It is perhaps unfortunate that no single treatise has yet been prepared on the Devonic fish fauna either of this country or of Europe, since the quest for information regarding the fossil assemblagés of any particular region, or concerning the structure of particular genera, involves no little expenditure of time and effort. A revised compendium, therefore, along the lines of the now somewhat antiquated monograph by Newberry would be an exceedingly welcome and useful contribution, and it is hoped that some such work may yet be undertaken.

\footnotetext{
' U. S. Geol. Sur. Monogr. v. I6. 1889.
} 
The memoir which is now presented, and whose inception is due largely to active interest of the present State Geologist of New York, is intended partially to supply the need of a general conspectus dealing with the fauna of a definite area and within a definite formation It must be understood, however, as being of much more modest pretensions and more limited in scope, than the aforementioned monograph by Professor Newberry. As the title indicates, it is concerned chiefly with the Devonic fish fauna of the New York-Pennsylvania region, revised descriptions being offered of every genus and nearly every species entering into its composition. Many of the larger groups have also been redefined in accordance with the present state of our knowledge respecting them. Obviously, however, our understanding of the forms occurring within the boundaries of two political divisions would be incomplete except as they are viewed in relation to other species, genera and faunas, irrespective of their geographical distribution. Moreover, a large proportion of the remains found in one state, owing to inferior preservation or other causes, would be obscure, perhaps even unintelligible, but for the occurrence of identical or kindred species in some other region. Let it be asked, for example, how much would be known of the structure of Bothriolepis if we were unable to extend our acquaintance beyond the extremely fragmentary specimens found in the New York and Pennsylvania Devonic? But as soon as comparisons are undertaken with the exquisitely preserved Canadian examples, even the poorest fragment from the former region becomes invested with new light and interest. Accordingly, in the following pages, we have not hesitated to take considerable notice, and even to introduce descriptions of extralimital forms, wherever such procedure appeared conducive to a more perfect understanding of the species comprised by the local fauna. And finally, at the end of the systematic descriptions, some general questions are discussed which deal with geographical distribution and with the relations of the fauna as a whole.

In the matter of formation names, preference has been given through- 
out to the classification of the New York series adopted by the geologists of this State, ${ }^{x}$ and to Prosser's classification of the Ohio Devonic. ${ }^{2}$

In the latter system it will be noted that the local names of "Columbus" and "Delaware limestones" are used for the lower Mesodevonic rocks instead of Onondaga (- Corniferous) of the New York classification, for the reason that it is probable these Ohio formations should be correlated with a later horizon than the Onondaga - namely, the lower part of the Erian series of New York. We may also remark in this connection that the weight of evidence furnished by fossil vertebrates is decidedly in favor of grouping the formation "Corniferous" of older geologists together with the Hamilton in a single division of the Mesodevonic. For the convenience of those who may not be perfectly familiar with the relations of the different systems, the following tables may be here inserted:

${ }^{2}$ Science, Dec. 8, r899; Anerican Geologist, Feb. I900; N Y. State Mus. Mem. 3. 1900; Univ. State N. Y. Handbook 19. 1903; N. Y. State Mus. Bul. 81, 82. 1905; 99. 1906; 107. 1907 .

2Nomenclature of the Ohio Geological Formations. Jour. Geol. I903. Ir: 519-46. 
Summary of classification of the New York Devonic according to John M. Clarke DESCENDING ORDER

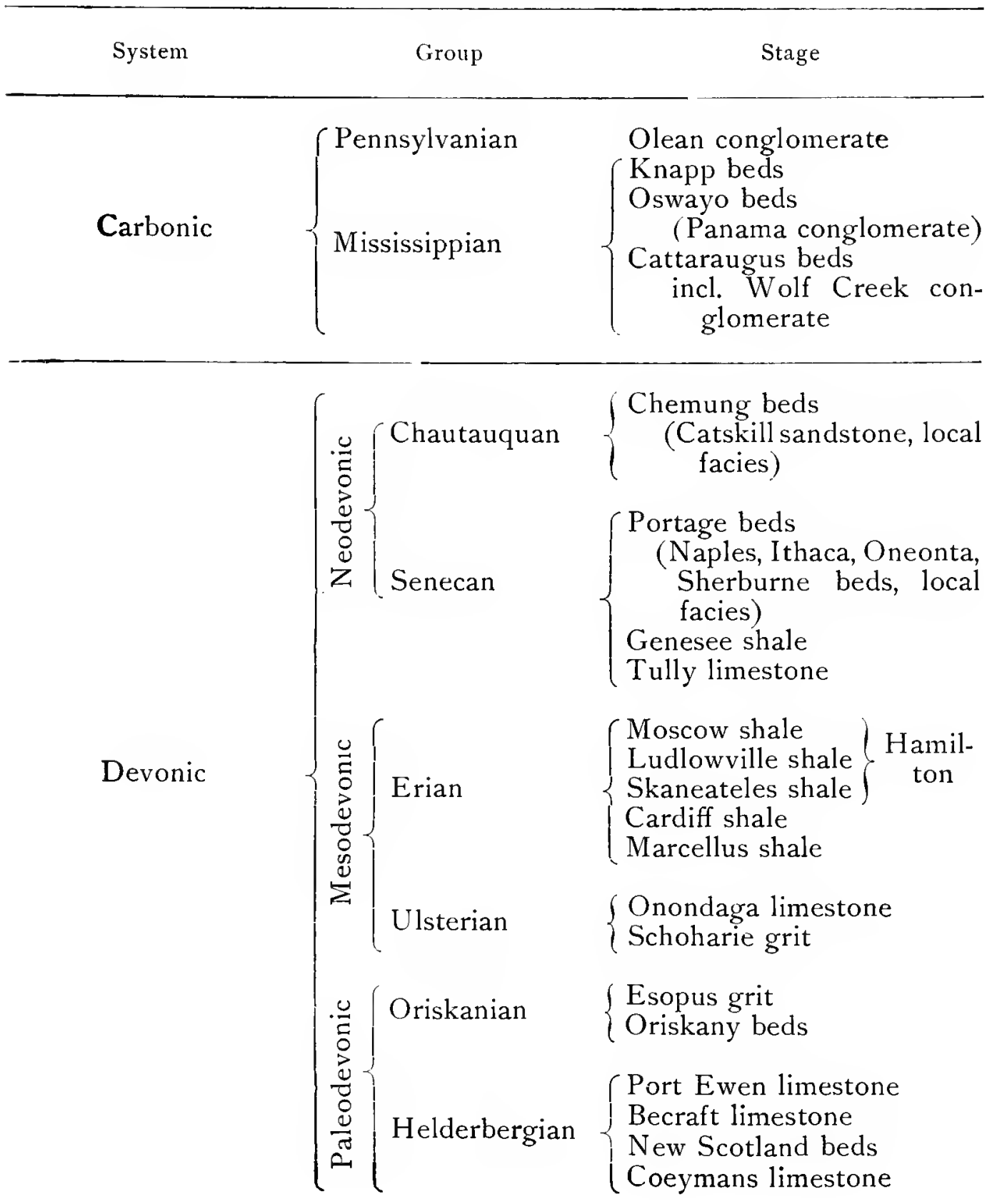


Classification of the New York Devonic according to James D. Dana DESCENDING ORDER

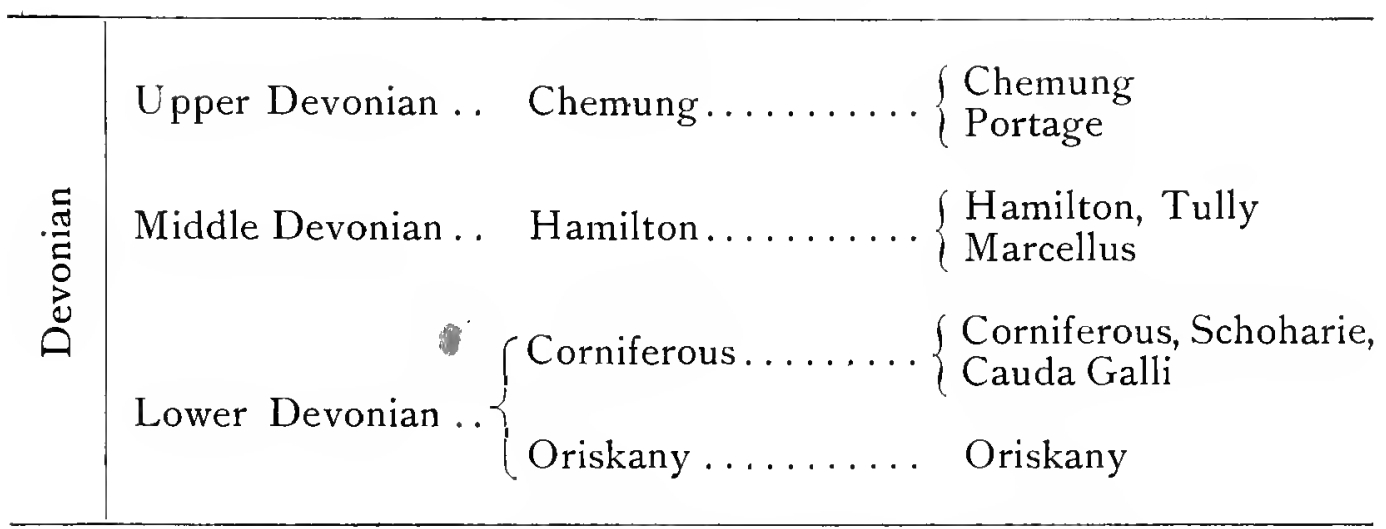

Classification of the Ohio Devonic according to Charles S. Prosser

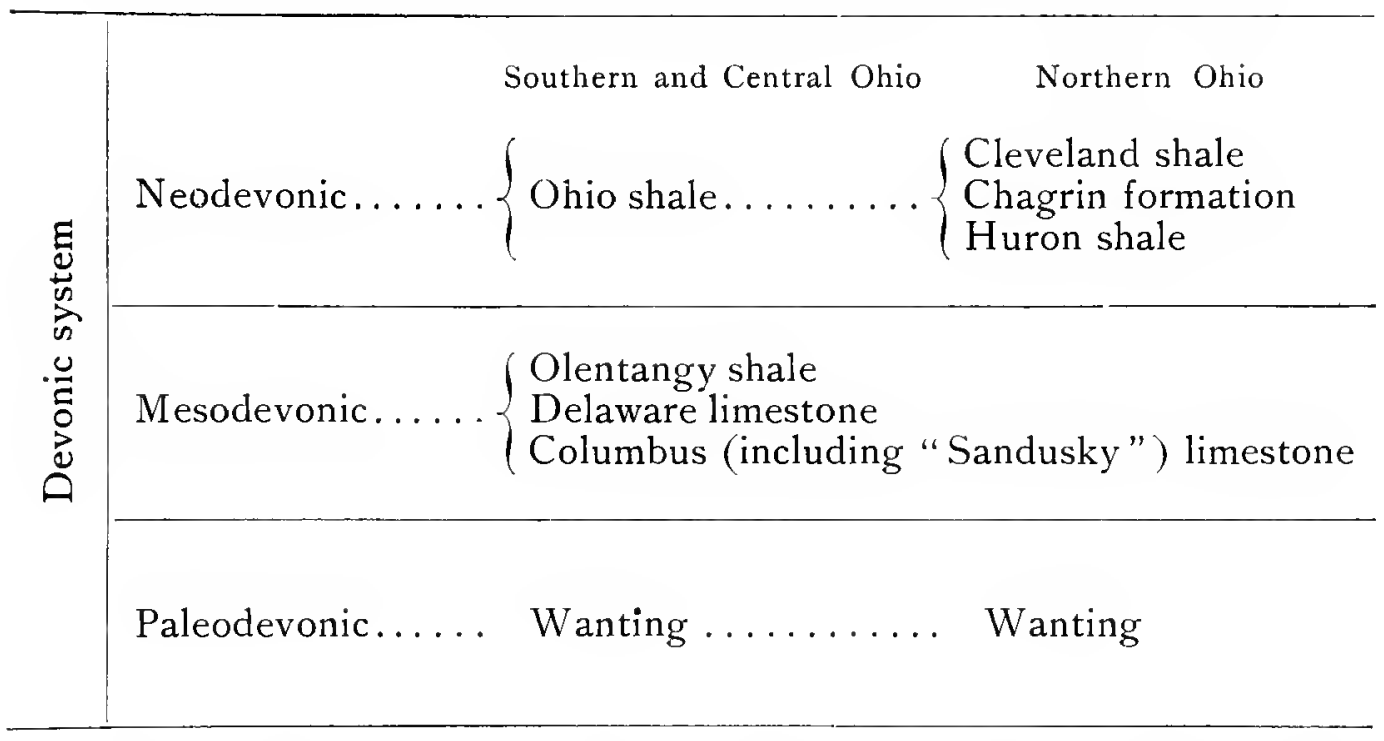

The definitions that are given of species and genera are based largely upon the writer's investigation of actual specimens, often including the original types, although due account has been taken of the diagnoses of earlier authors. Most of the definitions of higher groups are adopted with but little modification from the special literature. For the loan of speci- 
mens and other valuable aid rendered in the prosecution of these studies, the writer is under great obligations to Dr John M. Clarke. Other material has been freely placed at his disposal by Mr Charles Schuchert, of the Peabody Museum at Yale University, by Professor Bashford Dean, of Columbia University, and by the authorities of the American Museum of Natural History in New York. The illustrations, both for plates and text figures, have been provided by the Museum of Comparative Zoology at Harvard College, Cambridge, Mass., and the New York State Museum.

CONSPECTUS OF SPECIES ARRANGED ACCORDING TO THEIR GEOLOGICAL OCCURRENCE

CHAMPLAINIC

Class AGNATHA

Astraspis desiderata $W^{r}$ alcott. Lower Siluric of Canyon City, Col.

? Dictyorhabdus priscus IValcott. Lower Siluric of Canyon City, Col.

? Eriptychius americanus IV alcott. Lower Siluric of Canyon City, Col.

SILURIC

Class AGNATHA

Cyathaspis acadica Matthew. From strata of supposed Niagara age in Kings county, New Brunswick.

Palaeaspis americana Claypole. Bloomfield sandstone; middle portion of the Salina beds, Perry county, Pennsylvania.

\section{Class PIsces}

Onchus clintoni Claypole. Clinton beds (Lower Niagaran); Pennsylvania. Onchus pennsylvanicus Claypole. Bloomfield sandstone; middle member of the Salina beds, Perry county, Pennsylvania.

Onchus sp. Niagara beds of Cumberland, Maryland.

LOWER DEVONIC,

\section{Maine-New Brunswick province}

Class AGNATHA

Cephalaspis campbelltonensis Whiteaves. Lower Devonic; Campbellton, N. B. 
Cephalaspis dawsoni Lankester. Lower Devonic; Gaspé, Quebec.

Cephalaspis jexi Traquair. Lower Devonic; Campbellton, N. B.

Cephalaspis sp. Lower Devonic; Campbellton, N. B.

Thelodus scales. Oriskany sandstone, Nictaux Falls, N. S.

Asterolepis clarkei Eastman. Chapman sandstone (Lowermost Devonic); Aroostook county, Maine.

\section{Class PISCES}

Protodus jexi. Smith Woodward. Lower Devonic; Campbellton, N. B.

Doliodus problematicus Smith Woodzard. Lower Devonic; Campbellton, N. B.

Acanthodes semistriatus Smith Woodward. Lower Devonic; Campbellton, N. B.

Cheiracanthus costellatus Traquair Lower Devonic; Campbellton, N. B.

Climatius latispinosus (IVhiteaves). Lower Devonic, Campbellton, N. B. Homacanthus gracilis Whiteaves. Lower Devonic; Campbellton, N. B. Machaeracanthus sulcatus Newberry. Lower Devonic; Gaspé, Quebec. Gyracanthus incurvus Traquair. Lower Devonic; Campbellton, N. B. Phlyctaenaspis acadica (Whiteaves). Lower Devonic; Campbellton, N. B. Dendrodus arisaigensis Whiteaves. Arisaig series (Helderbergian?) ; Nova Scotia.

MIDDLE DEVONIC

Ulsterian (= "Corniferous") stage ; New York, Ohio, Indiana and Canada Class AGNATHA

Shagreen granules of Thelodus, Coelolepis etc. Columbus limestone; Ohio.

\section{Class PISCES}

Cladodus prototypus Eastman. Columbus limestone; Columbus, O. ? Psammodus antiquus Newberry. Columbus limestone; Ohio.

Ptyctodus punctatus Eastman. Onondaga limestone; Le Roy, N. Y. Rhynchodus secans Newberry. Columbus and Delaware limestones; Ohio. Palaeomylus crassus (Newberry).

Palaeomylus frangens (Newberry).

Cyrtacanthus dentatus Newberry.

“ “

“

، 
Machaeracanthus peracutus Newberry. Columbus and Delaware limestones; Ohio. Onondaga limestone; Le Roy and Lime Rock, N. Y. Machaeracanthus sulcatus Newbery. Delaware limestone; Ohio and Canada. Onondaga limestone; New York.

Machaeracanthus major Newberry. Columbus and Delaware limestones; Ohio.

Acantholepis fragilis Nczuberry. Columbus and Delaware limestones; Ohio. Onondaga limestone; New York.

Macropetalichthys rapheidolabis Norwood \& Owen. Columbus and

Delaware limestones; Ohio and Indiana, also from rocks of equivalent age in Ontario and James Bay region, Canada. Onondaga limestone; Le Roy, N. Y.

Asterosteus stenocephalus Newberry. Delaware limestone; Ohio.

Acanthaspis armata Newberry. Delaware limestone; Ohio. Onondaga limestone; Le Roy, N. Y.

Protitanichthys fossatus Eastman. Delaware limestone; Ohio.

Coccosteus (Liognathus) spatulatus Ncwberry. Delaware limestone; Ohio. Coccosteus occidentalis Ncwbory.

Coccosteus sp. Onondaga limestone; Clifton Springs, N. Y.

Dinichthys precursor $(N e w b r r y)$. Columbus limestone; Ohio.

Onychodus sigmoides Newberry. Columbus and Delaware limestones;

Ohio. Onondaga limestone; New York, and (?) Hamilton limestone; Milwaukee, Wis.; Cedar Valley limestone; Iowa.

\section{Erian stage (Marcellus and Hamilton); New York}

\section{Class PISCES}

Dermal denticles, possibly of Cladoselache. Marcellus shale; Le Roy, N. Y.

Ctenacanthus wrighti Nezuberry. Moscow shale (Upper Hamilton); Yates county, N. Y.

Machaeracanthus longaevus Eastman. Lower Hamilton; Eighteen Mile creek, N. Y., and (?) Milwaukee, Wis. 
Dinichthys halmodeus (Clarke). Marcellus shale; Livonia and Manlius, N. Y.

Dinichthys lincolni Claypole. Marcellus shale; Geneva, N. Y.

? Aspidichthys sp. Hamilton; East Bethany, N. Y.

Arthrodire fragments. Encrinal limestone (Hamilton); Eighteen Mile creek, N. Y

Crossopterygian scales (Holoptychius). Lower Hamilton; Oran, Onondaga county, N. Y.

\section{Erian stage; Wisconsin, Ontario and Manitoba}

Class PIsces

Cladodus monroei Eastman. Hamilton limestone; Milwaukee, Wis.

Ptyctodus calceolus Newberry \& Worthen. Hamilton limestone;

Wisconsin and Ontario, "Cuboides zone" of the Devonic; Manitoba.

Ptyctodus ferox Eastman. Hamilton limestone; Milwaukee, Wis.

Rhynchodus excavatus Newberry. Hamilton limestone; Milwaukee, Wis.

Cedar Valley limestone; Iowa.

Rhynchodus sp. ind. "Cuboides zone" of the Devonic; Manitoba.

Palaeomylus greenei (Newberry). Hamilton limestone; Milwaukee, Wis.

Acantholepis fragilis Newberry.

Phlyctaenacanthus telleri Eastman.

Heteracanthus politus Newberry. Hamilton limestone; Milwaukee, Wis.

Cedar Valley limestone; Iowa.

Heteracanthus uddeni Lindahl. Hamilton limestone; Milwaukee, Wis.

Cedar Valley limestone; Illinois.

Machaeracanthus sp. (= M. longaevus Eastman?) Hamilton limestone;

Milwaukee, Wis.

Dinichthys canadensis Whiteaves. "Cuboides zone" of the Devonic; Manitoba.

Dinichthys pustulosus Eastman. Hamilton limestone; Milwaukee, Wis.

Cedar Valley limestone; Iowa and Illinois.

Dinichthys tuberculatus Newberry. Hamilton limestone; Milwaukee, Wis.

Cedar Valley limestone; Iowa. 
Dinichthys sp. Hamilton limestone; Milwaukee, Wis.

Sphenophorus sp. " " “

Aspidichthys (?) notabilis Whiteaves. Hamilton limestone; Ontario.

"Cuboides zone" of the Devonic; Manitoba.

Onychodus sigmoides Newberry. Hamilton limestone; Milwaukee, Wis.

Cedar Valley limestone; Iowa.

Onychodus sp. ind. "Cuboides zone" of the Devonic; Manitoba.

\section{Erian stage (Cedar Valley limestone); Iowa and Illinois}

Ptyctodus calceolus Nezuberry \& Worthen.

Ptyctodus ferox Eastman.

Rhynchodus sp.

Rhynchodus excavatus Newberry.

Heteracanthus politus Newberry.

Heteracanthus uddeni Lindahl.

Labial cartilages of Dipterus (?).

Dipterus calvini Eastman. Fairport, Ia.

Dipterus uddeni Eastman. Buffalo, Ia.

Dinichthys pustulosus Eastman. Rock Island, Ill.

Dinichthys tuberculatus Newberry. Waterloo, Ia.

Onychodus sigmoides Newberry. Waverly, Ia.

$$
\text { UPPER DEVONIC }
$$

\section{Upper Devonic of the Quebec province}

\section{Class AGNATHA}

Cephalaspis laticeps Traquair. Upper Devonic; Scaumenac bay, Quebec. Euphanerops longaevus Woodward.

Bothriolepis canadensis Whiteaves.

\section{Class PISCES}

Diplacanthus striatus Agassiz. Upper Devonic; Scaumenac bay, Quebec. Diplacanthus horridus IToodward. Acanthodes affinis Whiteaves. Acanthodes concinnus Ithitcaics.

“"


Scaumenacia curta (Whiteaves). Upper Devonic; Scaumenac bay, Quebec. Coccosteus canadensis Woodrerard.

Holoptychius quebecensis (Whiteaves)."

Eusthenopteron foordi Whiteaves.

Cheirolepis canadensis Whiteaves.

Senecan stage (Tully limestone, Genesee shale and Portage beds); New York Class PISCES

Cladoselache sp. Naples shale (Portage); Eighteen Mile creek, N. Y. Acanthodes ? pristis Clarke. Rhinestreet shale (Portage); Sparta.

Ptyctodus calceolus Newb. \& $W$. Genesee shale; Eighteen Mile creek and Portage of Naples, N. Y.

Ptyctodus sp. Goniatite or Parrish limestone (Portage group). Naples, N. Y.

Apateacanthus vetustus (Clarke). Cashaqua shale (Portage); Milo, Yates co., N. Y.

Heteracanthus politus Newberry. Portage shale; New York.

Undetermined fin spine. Tully limestone; Cayuga lake, N. Y.

Dermal denticles of (?) Cladoselache. Genesee shale; Le Roy, N. Y.

Dinichthys newberryi Clarke. Genesee shale; Bristol Center and Canandaigua lake, N. Y.

Dinichthys ringuebergi Newberry. Portage (Rhinestreet) shale; Sturgeon point, near Buffalo, N. Y.

Dinichthys pustulosus Eastman. Oneonta beds; New York.

Dinichthys dolichocephalus Eastman. Portage (Rhinestreet) shale; Sturgeon point, near Buffalo, N. Y.

Dinichthyid. Oneonta beds; Oxford, N. Y.

Dinichthys sp. Genesee shale; Eighteen Mile creek, N. Y.

Dinomylostoma beecheri Eastman. Cashaqua (Portage) shale; Mount Morris, N. Y.

Callognathus serratus Newberry. Portage shale; Eighteen Mile creek, N. Y. Palaeoniscus? devonicus Clarke. Genesee shale; Glenville, North Evans, 
and New Albany Black shale of Kentucky. Also Rhinestreet shale (Portage) of Sparta.

Palaeoniscus ? antiquus, $H$. U. Williams. Rhinestreet shale (Portage); Eighteen Mile creek, N. Y.

Palaeoniscus? reticulatus, $H$. U. Williams. Rhinestreet shale (Portage); Eighteen Mile creek, N. Y.

Dipterus ithacensis, H. S. Williams. Ithaca beds (Portage); Ithaca, N. Y.

Ohio shale (Huron, Erie and Cleveland shales); Ohio and Kentucky

\section{Class PISCES}

Phoebodus politus Newberry. Cleveland shale; Lorain county, O.

Cladodus claypolei Hay. Cleveland shale; Rocky river, $\mathrm{O}$.

Cladodus concinnus Newberry. Cleveland shale; Lorain county, $\mathrm{O}$.

Cladodus rivi-petrosi Claypole. Cleveland shale; Rocky river, $\mathrm{O}$.

Cladodus subulatus Newberry. Cleveland shale; Ohio.

Cladodus terrelli Neaborry. Cleveland shale; Lorain county, O.

Cladodus tumidus Newberry. Cleveland shale; Sheffield, O.

Monocladodus clarki Claypolc. Cleveland shale; Ohio.

Monocladodus pinnatus Claypole.

Cladoselache clarki Claypole.

Cladoselache fyleri Newberry. Cleveland shale; Cuyahoga county, O.

Cladoselache kepleri Ncwberry.

Cladoselache sinuatus (Claypole). Cleveland shale; Ohio.

Orodus elegantulus Ncwberry. Subcarbonic ? Ohio.

Xenodus herzeri $(N e w b c r y)$. Huron shale; Ohio.

Polyrhizodus modestus. Nevberry. Subcarbonic ? Ohio.

Hoplonchus parvulus Newberry. Cleveland shale; Bedford, O.

Ctenacanthus angustus Newberry. Berea grit; Berea, O.

Ctenacanthus clarki Newberry. Cleveland shale; Berea, O.

Ctenacanthus compressus Ncwberry. Cleveland shale; Lorain county, $\mathrm{O}$.

Ctenacanthus vetustus Newberry. Cleveland shale; Sheffield county, O.

Coccosteus cuyahogae Claypole. Cleveland shale; Cuyahoga county, O. 
Dinichthys clarki Claypole. Cleveland shale; Berea, O.

Dinichthys curtus Newberry. Cleveland shale; Cleveland, O.

Dinichthys gouldi Newberry. Cleveland shale; Berea, O.

Dinichthys gracilis Claypole.

"

Dinichthys herzeri Newberry. Huron shale; Delaware, O.

Dinichthys intermedius Newberry. Cleveland shale; Lorain county, O.

Dinichthys minor Newberry.

Dinichthys prentis-clarki Claypole. Cleveland shale; Ohio.

Dinichthys terrelli Newberry. Cleveland shale; Lorain county, O.

Brontichthys clarki Claypole. Cleveland shale; Cuyahoga county, O.

Stenognathus corrugatus (Newberry). Cleveland shale; Lorain county, O.

Titanichthys agassizii Newberry.

Titanichthys attenuatus Wright. Cleveland shale; Ohio.

Titanichthys brevis Claypole.

Titanichthys clarki Nezuberry. Cleveland shale; Lorain county and Berea, O.

Titanichthys rectus Claypole. Cleveland shale? Ohio.

Titanichthys sp. indet.

Selenosteus kepleri Dean.

Stenosteus glaber Dean.

Diplognathus mirabilis Newberry. Cleveland shale; Lorain county, O.

Callognathus serratus Nezeberry.

Trachosteus clarki Nezeberry. Cleveland shale; Berea, O.

Mylostoma variabile Nczuberry. Cleveland shale; Sheffield, O.

Glyptaspis verrucosa Newberry.

Aspidichthys clavatus Newberry. Huron shale; Delaware, O.

Ctenodus wagneri Newberry. Cleveland shale; Cleveland, O.

Onychodus ortoni Newberry. Huron shale; Franklin county, O.

Actinophorus clarki Newberry. Cleveland shale; Cuyahoga county, O.

MIDDLE OR UPPER DEVONIC; KENTUCKY

Tamiobatis vetustus Eastman. Powell county, Ky. 


\section{Upper Devonic of Iowa and Illinois}

Class PISCES

Diplodus priscus Eastman. Upper Devonic; Elmhurst, Ill.

Diplodus striatus Eastman.

Diplodus sp. ind.

“" ،

“

Ptyctodus calceolus Newb. $\mathcal{F} W$. Upper Devonic; Elmhurst, Ill. Also

State Quarry, Lime Creek and Sweetland Creek beds, Iowa.

Ptyctodus compressus Eastman. State Quarry beds; Johnson county, Ia.

Ptyctodus ferox Eastman. State Quarry beds; Johnson county, Ia

Dinichthys pustulosus Eastman.

Synthetodus trisulcatus Eastman.

Dipterus costatus Eastman.

Dipterus mordax Eastman.

\section{Upper Devonic of Colorado}

Class AGNATHA

Bothriolepis coloradensis Eastman. Elbert formation; Rockwood.

Class PISCES

Holoptychius giganteus Agassiz. Elbert formation; Devon Point. Holoptychius tuberculatus Newberry: Elbert formation; Devon Point. Arthrodire fragments. Elbert formation; Devon Point.

Chautauquan stage (Chemung-Catskill); New York and Pennsylvania.

\section{Chemung group}

Class AGNATHA

Bothriolepis minor Leidy. Chemung group; Bradford county, Pa. Catskill ; Delaware county, N. Y.

\section{Class PISCES}

Cladodus coniger Hay. Chemung group; Warren, Pa.

Cladodus sp. High Point sandstone; Naples, N. Y.

Helodus gibberulus Agassiz. Chemung group; Warren, Pa.

Rhynchodus pertenuis Eastman. Chemung group; Franklin, N. Y. 
Rhynchodus sp. High Point sandstone; Naples, N. Y.

Homacanthus acinaciformis Eastman. Chemung group; Warren, Pa.

Ctenacanthus chemungensis Claypole. Chemung group; New York and Pennsylvania.

Ctenacanthus randalli Newberry. Olean conglomerate; Warren, Pa.

Gyracanthus sherwoodi Newberry. Chemung group; Pennsylvania and Cattaraugus county, N. Y.

Coccosteus macromus Cope. Chemung group; Le Roy, Pa.

Dinichthys curtus Newberry. Chemung beds; Warren, Pa.

Dinichthys tuberculatus Nezeberry. Chemung group; Warren, Pa.

Holonema rugosum (Claypole). Franklin, Delaware county, N. Y. and Pennsylvania.

Holonema horridum Cope. Chemung group; Pennsylvania.

Phyllolepis delicatula Nezuberry. Chemung group; Bradford county, Pa. Sphenophorus lilleyi Newberry. Chemung group; Le Roy, Bradford co., $\mathrm{Pa}$.

Dipterus alleghaniensis Williams (= nelsoni Newberry; Warren, Pa.) Cuba sandstone; Allegany county, N. Y.

Dipterus flabelliformis Newberry. Chemung group; Warren, Pa.

Dipterus minutus Newberry. Chemung conglomerate; Warren, Pa.

Dipterus nelsoni Newberry.

Heliodus lesleyi Newberry. Chemung group; northern Pennsylvania.

Ganorhynchus beecheri Nezwberry. Chemung group; Warren, Pa.

Apedodus priscus Leidy. Chemung group; Pennsylvania.

Strepsodus sp. (Detached tooth; also fragments of Osteolepis sp., fide Cope).

Holoptychius americanus Leidy. Chemung group; Delaware county, N. Y. and Pennsylvania

Holoptychius filosus Cope.

Holoptychius giganteus Agassiz. Pennsylvania. (Also Upper Devonic of Colorado).

Holoptychius granulatus Newberry. Chemung group; northern $\mathrm{Pa}$. 
Holoptychius pustulosus Newberry. Chemung group; Warren, Pa. Holoptychius tuberculatus Newberry. Le Roy, Bradford co., Pa. (Also Upper Devonic of Col.)

\section{Catskill beds}

Class AGNATHA

Bothriolepis nitida (Leidy). Tioga county, Pa. and Delaware county, N. Y. Bothriolepis minor Newberry. Le Roy, Bradford co., Pa. and Delaware county, N. Y.

\section{Class PIsces}

Onchus rectus ${ }^{-E a s t m a n . ~ D e l a w a r e ~ c o u n t y, ~ N . ~ Y . ~}$

Gyracanthus sherwoodi Newherry. Mansfield, Tioga co., Pa.

Dinichthys sp. Franklin, N. Y.

Holonema rugosum (Claypole). Bradford county, Pa.

Dipterus angustus Newberry.

Dipterus contraversus Hay. Tioga county, Pa.

Dipterus fleischeri Newberry. Tioga county, Pa. and Franklin, Delaware co., N. Y.

Dipterus sherwoodi Newberry. Tioga county, Pa.

Ganorhynchus beecheri Newberry. Warren, Pa.

Holoptychius americanus Leidy. Tioga county, Pa.

Holoptychius giganteus Agassiz.

Holoptychius halli Newberry. Delhi, N. Y.

Holoptychius radiatus Newberry. Blossburg, Pa.

Sauripteris taylori ( Hall)

Glyptopomus sayrei Newberry. Susquehanna river near mouth of Mehoopany. 
DEVONIC FISHES OF THE NEW YORK FORMATIONS

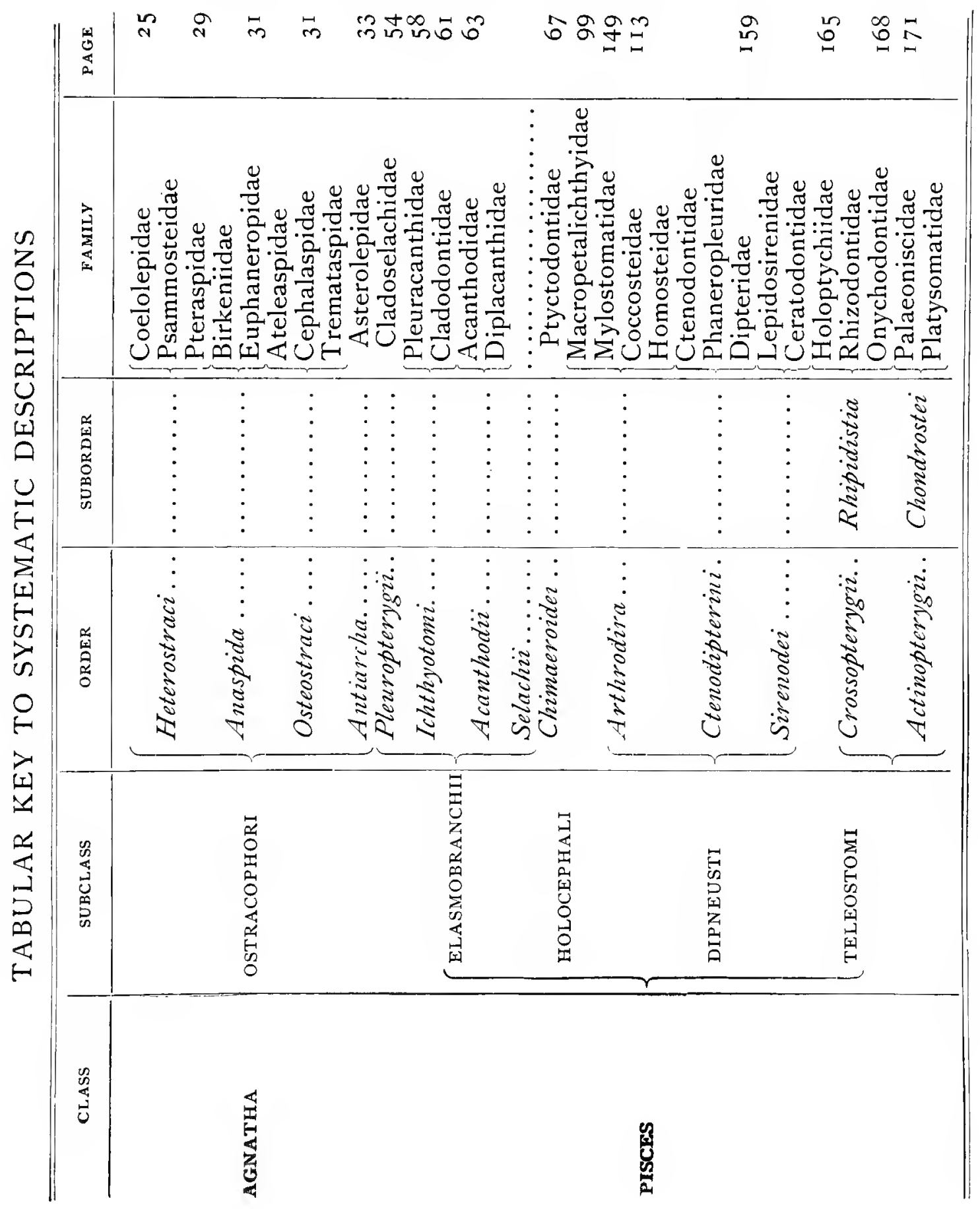




\section{SYSTEMATIC ACCOUNT OF DEVONIC FISHES, PRINCIPALLY FROM NEW YORK AND PENNSYLVANIA Class AGNATHA Subclass OSTRACOPHORI}

Paleontology furnishes no clue as to the origin of the primitive fishlike vertebrates which appear sparsely in the Siluric and Devonic rocks of this country and Europe. That the most ancient forerunners of fishes were soft-bodied, like the lowest chordates of the present day, and hence not suitable for preservation in the fossil state, is more than likely; but from what branch of invertebrates they are descended still remains problematical. It is customary to regard fishes proper as having all been derived from primitive Elasmobranchs, the presence of the latter being indicated by fragmentary remains as early as the Siluric. Whether or not the class of curious forms known as Agnatha, characterized, as their name indicates, by the lack of ordinary jaws, have a common ancestry with Elasmobranchs or are of independent origin, we are without sufficient enlightenment. On the one hand, the similarity of Coelolepid scales to Elasmobranch shagreen can not be regarded as proof of community of descent, since the possibility of parallelism, especially as affects simple hard parts, is by no means excluded. On the other hand, competent students who have most carefully examined this matter are practically unanimous in affirming that paleontology offers no support for the view that the most ancient fishlike forms are in any way related to crustacean or arthropod ancestors. Such external resemblances as exist between Ostracophores and contemporaneous Eurypterids may be looked upon as interesting examples of mimicry between organisms of widely different grades which are adapted to live in the same way and amid similar conditions.

In common with Pisces proper the Agnatha possess a fishlike form of body, median fins, a tail that may be either naked or scaly, well defined sensory grooves, branchial apertures, and dermal armor having a microscopic structure similar to that of true bone. Only in a single family of 
the Heterostraci is there a noteworthy absence of bone lacunae and tubules in the microscopic structure of the dermal plates, but recent discoveries of entire bodies of Thelodus, Lanarkia, Drepanaspis etc. [text fig. 1, 2] seem to demonstrate that the hard shield of Pteraspidians arose through fusion of separate shagreen tubercles and spinelets. Incontestably, therefore, the
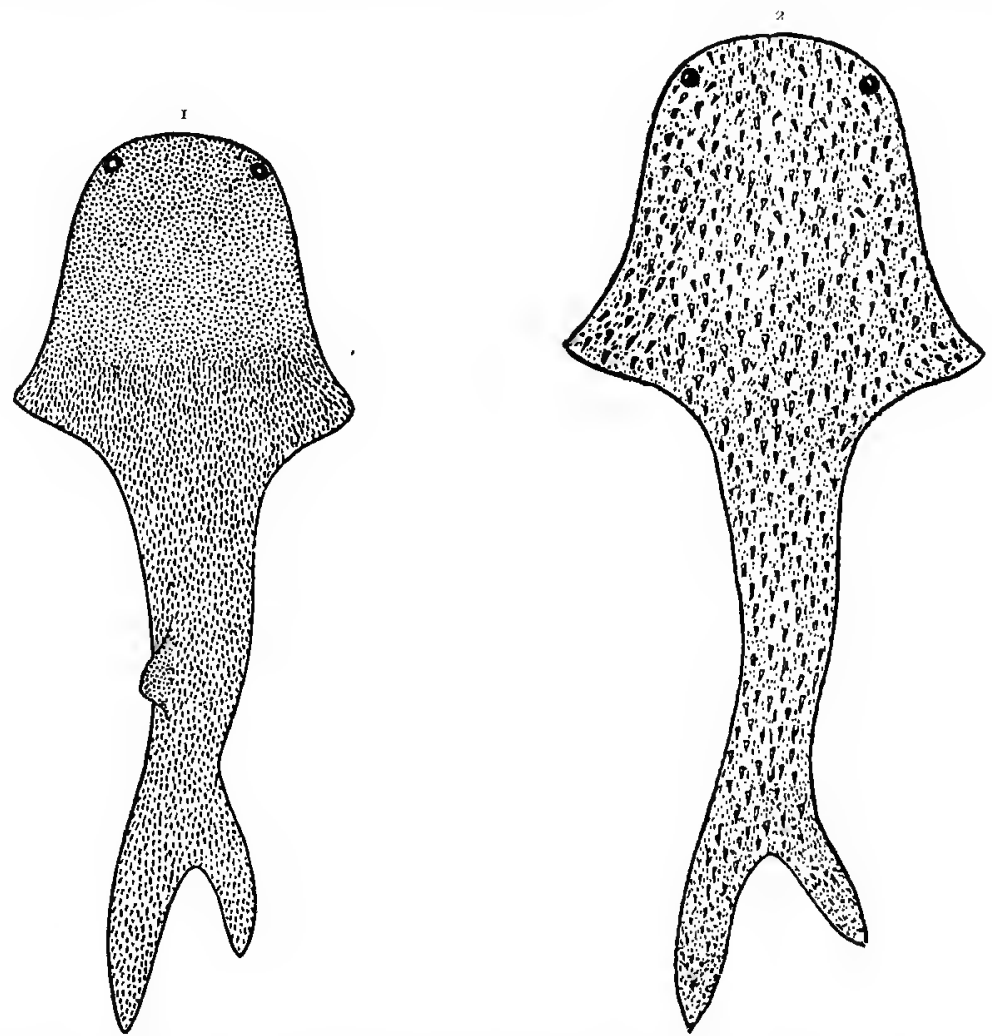

Fig. I Diagrammatic restoration of 'Thelodus scoticus Traq., showing the dursal fin and position of the eyes. The tail is flexed, turned round so as to show the caudal fin in profile. (After Traquair)

Fig. 2 A similar outline of $L$ anarkia spinosa Traq. In this genus the eyes have been found (L. hor $r i d a)$, but not the dorsal fin as yet. (After Traquair)

Agnatha must be looked upon as chordate animals; yet it does not follow that they are true fishes. On the contrary, the characters which separate them from the latter class are most trenchant, and are not adequately expressed in the taxonomic system except by allotting to them the rank of an independent class. For instance, in marked distinction from fishes proper, none of the Ostracophores exhibits the slightest trace of ordinary 
jaws, of a segmented axial skeleton in the trunk, or of arches for the support of paired limbs. Indeed, appendages themselves are confined to a single order, the Antiarcha, where oarlike swimming organs appear to have developed from an integumentary fold on either side of the body, unsupported by rays, and in a manner fundamentally different from the fins of typical fishes. It is extremely doubtful whether the jointed pectoral limbs of the Asterolepidae can be regarded in any sense as homologous with the fins of fishes.

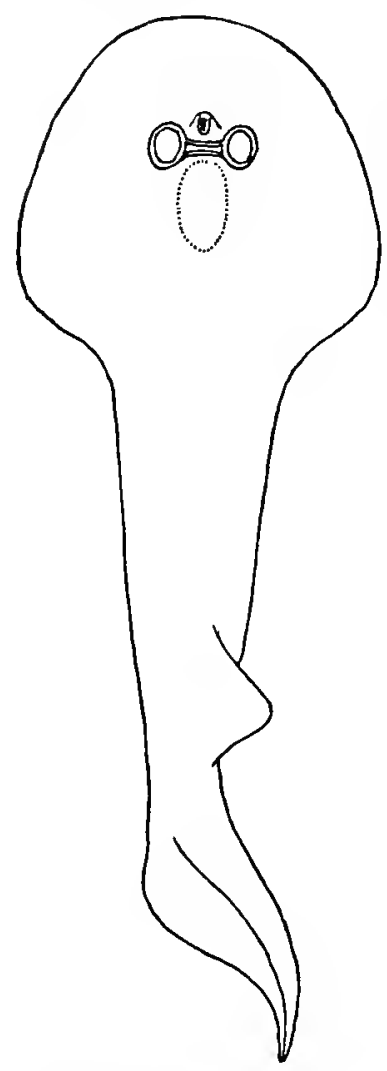

Fig. 3 Diagrammatic restored outline of Ateleaspis tessellat a Traq., the tail turned round so as to appear in profile (After Traquait)

Within the last decade, our knowledge of the variety, structure and mutual relationships of primitive chordates has been vastly increased. Familiar genera have been most assiduously reinvestigated, their occurrence has been detected in fresh localities, and many new forns of the utmost importance and interest have been brought to light. It will suffice to mention here only the classic researches of the late Dr Ramsey H. Traquair on the Old Red sandstone fishes of North Britain, and the beautifully preserved Drepanaspis from the Hunsrück slate (Lower Devonic) of Rhenish Prussia; whereas in this country, the principal advance has been made by Professor William Patten, of Dartmouth College, in his studies of Bothriolepis and the Tremataspidae.

Amongst other results achieved within recent years, not the least important is the insight which has been gained concerning interrelations and probable lines of descent among the different orders of Ostracophores. Reference has already been made to the discovery of primitive genera which throw a flood of light upon the affinities of Pteraspis and its allies, and enable us to trace them back to an ancestral family in which the dermal armor retained its generalized form of shagreen 
granules. Still more far-reaching in its consequences is Traquair's discovery of Ateleaspis [text fig. 3], a form considered by him to indicate a genetic connection between the Heterostraci and Osteostraci. Assuming the correctness of the Scottish author's conclusions, ${ }^{r}$ not only Pteraspis, Palaeaspis, Cyathaspis, and the like, but also Cephalaspis, are traceable to the primitive Coelolepidae, in which the dermal covering consists of small shagreen granules, or of minute hollow spines. Only in the case of the Antiarcha, the order to which Pterichthys and Bothriolepis belong, does their immediate origin remain uncertain, owing to the absence of intermediate forms linking them either with Pteraspids or Cephalaspids. Notwithstanding their nearer approach to the latter, as indicated by the presence of bone lacunae and dorsal fins, it is practically certain that they could have had no direct derivation from that group; and an inverse hypothesis, by which the Cephalaspids are derived from the Asterolepids, appears vastly improbable. As to the theory, recently revived in some quarters, that Asterolepids are transitional between vertebrates and invertebrates, and are more or less

I A dissenting opinion has lately been expressed by Mr C. Tate Regan, in his article on the "Phylogeny of the Teleostomi" [Ann. Mag. Nat. Hist. ser. 7, I904. I3:329-49]. Admitting, as he does, the resemblance between Ateleaspis and Cephalaspis, yet he cannot see that there is "the least reason for regarding it [Ateleaspis] as allied to anything else," and accordingly denies that it is annectant between the Heterostraci and Cephalaspidae. The latter family is considered by Mr Regan to have been derived from the Asterolepidae, being in fact specialized and degenerate members of that group, a view which lacks the support of morphological evidence, and is at variance with the known facts of geological succession.

The extreme position taken by Mr Regan is apparent from the following extract: "The Placodermi (Coccosteidae, Asterolepidae, Cephalaspidae) are a natural group, not related to the Heterostraci, which are Chondropterygii. They may probably be regarded as armored primitive Crossopterygii, this view being in accord with $(a)$ the arrangement of the cranial roof bones in Coccosteus; (b) the structure of the ventral fin in Coccosteus; (c) the structure of the pectoral limb of the Asterolepidae. . . The Teleostomi probably originated from the Pleuropterygian Elasmobranchii in the Lower Silurian, and the Crossopterygii, with their specialized off shoots, the Dipneusti and Piacodermi, must have rapidly evolved, since all are well represented in the Lower Devonian, and the highly specialized Cephalaspidae are found in the Upper Silurian." [p. 347] Some further discussion of the problems here involved will be found in an article on "Asterolepid Appendages," published in the Amcrican Journal of Scienco for August I 904. 
specially related to Ascidians, Crustaceans or Arachnids, this seems to be clearly disproved by the following well known facts: (I) the dermal plates are composed of true bone; (2) the head shield and body armor of Asterolepids have a well developed sensory canal system; (3) in Pterichthys, at least, there is a tail covered with scales, a dorsal fin, and a genuinely piscine heterocercal caudal fin.

Of the four orders of Ostracophores now commonly recognized, all have American representatives. The simplest forms (Anaspida and Heterostraci) occur in the Siluric and Devonic, and are without paired appendages. Bone cells are probably present in the calcifications of the Anaspida, but wholly lacking in the Heterostraci. The third order (Osteostraci) is confined, as a rule, to the Siluric and Lower Devonic, though occasionally met with in the Upper Devonic. Bone cells are present, but there is no trace of dermal sense organs either upon or within the shield. The fourth order (Antiarcha), with a complex system of dermal plates and a remarkable pair of appendages, is essentially Devonic, and as abundant in the uppermost, as in the lowest strata. The subclass becomes extinct at the close of the Devonic, without taking part in the evolution of the fishes of later periods.

\section{Order HETEROSTRACI}

These primitive Ostracophores are represented in the Paleozoic rocks of North America by two genera, Cyathaspis and Palaeaspis, occurring in the Siluric, and by a variety of Theloduslike scales from the Lower and Middle Devonic. No indications of such forms, however, have yet been discovered within the limits of New York State. The only American species of Cyathaspis that has been described, C. ac a dica (Matthew), is founded upon indifferently preserved material from strata of supposed Niagara age in New Brunswick, and is the oldest trace of vertebrate life yet discovered in Canada. Palaeaspis likewise appears to be known in this country by a solitary species occurring in the middle portion of the Salina beds in Perry county. Pennsylvania. In view of the conflicting statements which exist in the literature concerning the synonymy, geological horizon 
and alleged appendages of this form, the following brief notice may be given of it here.

\section{Palaeaspis americana Claypole}

I884 P a la e as pis a meric ana E. Ir. Claypole. Am. Nat. 18: 1224

$1884 \mathrm{Pal}$ a easpis bitruncata E. $W^{*}$ Claypole. Ibid. p. 1224

I885 Pal a a s pis a mericana E. Wr. Claypole. Geol. Soc. Quar. Jour. 41:62, woodcut fig. 7

$1885 \mathrm{P}$ al a e as p is bitruncat a E. $W$. Claypole. Ibid. p. 62, woodcut fig. 8

1885 Palaeaspis bitruncata and P. ell ipt ic a E. W. Claypole. Am. Ass'n

Adv. Sci. Phila. Meeting Proc. p. $4^{26}$

1885 Palaeaspis elliptica E. W. Claypole. Brit. Ass'n Adv. Sci. Montreal Meeting Rep't, p. 733

$1892 \mathrm{P}$ a la a s p is a merican a E. W. Claypole. Geol. Soc. Quar. Jour. 48: $5^{6} \mathrm{I}$, fig. 8

I893 $\mathrm{Pal}$ a e aspis americana E. $W$. Claypole. Am. Nat. 27:375

r $895 \mathrm{P}$ a l a e as pis a mericana $B$. Dean. Fishes, Living and Fossil, p. $7 \mathrm{r}$

I $898 \mathrm{Pal}$ a e as pis a mericana $A$. $S$. Woodurard. Outlines of Vertebrate Palaeontology, p. 6

This species, which differs from the British P. sericea only in minor particulars, is known by a few imperfect specimens, one or two of which

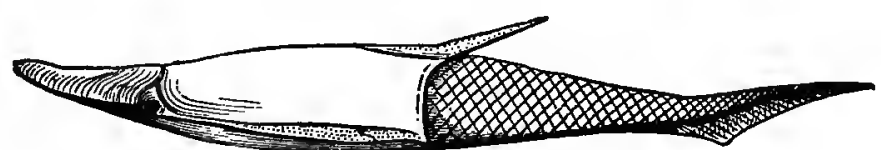

Fig. 4 Pteraspis rostrat a Agassiz. Lower Old Red sandstone; Great Britain. Lateral aspect of partially restored individual. $\mathrm{x} 3 / 4$

have the dorsal and ventral shields preserved in natural association. The dorsal shield resembles that of Pteraspis [text fig. 4] in form, but apparently consists of a single plate, and is destitute of a posterior median spine. The orbits, also, are not completely inclosed. In the original description, the dorsal and ventral shields were described under different names. Subsequently, however, the form named $\mathrm{P}$. bitruncat a was determined to be the ventral shield of $P$. a m eri c a n a, and the title proposed for it dropped. The undefined name of "P. elliptica" is probably to be regarded as a synonym of $\mathrm{P}$. a mericana. 
Neither in this species nor in Cyathaspis has the presence of paired appendages been definitely determined, notwithstanding that claims have occasionally been made as to their occurrence. According to Dr Bashford Dean, who examined Professor Claypole's type material, the specimens which were regarded by their original describer as fins are probably crushed Elasmobranch spines which have become accidentally associated with the thoracic region of the shield. Hence, the published figure of Claypole's restoration, which reappears from time to time in geological textbooks, is obviously misleading. The supposition that one or more pairs of appendages were present in Tremataspis, advocated in several of Professor Patten's papers, ${ }^{\mathrm{r}}$ is purely gratuitous, and contrary to probability. The perforations in the shield which this author thinks may have served for the attachment of swimming organs are interpreted as branchial orifices by the majority of writers.

Occasionally one meets with the statement, as for instance, in Dr O. P. Hay's valuable Catalogue of Fossil Vertebrata from North America, that the species under discussion occurs in the Devonic of Pennsylvania, an error which is perhaps attributable to confusion of formation names. The term "Onondaga group," as used by Claypole, was not intended to apply to the Mesoderonic Onondaga limestone, but to the beds formerly known as the "Onondaga salt group," now more generally termed the Salina. The horizon of these beds corresponds with that of the English Ludlow, or with the interval between that and the Wenlock. According to the Pennsylvania reports, the whole mass of the Salina shale in Perry county is about I 500 feet in thickness, and for the most part, with the exception of these fragments of Palaeaspis and the spines of Onchus, entirely unfossiliferous.

s On the Structure and Classification of the Tremataspidae. Am. Nat. 1902. 36:37993, and Imp. Acad. Sci. St Petersburg Men. 5. Ser. 8, v. r3, r903; On the Origin of Vertebrates, with Special Reference to the Structure of Ostracoderns. Verhandl. V. Internat. Zoologen-Congresses zu Berlin, 1902; On the Appendages of Tremataspis. Am. Nat. 1903. $37: 223^{-42}$. 


\section{Orders ANASPIDA and OSTEOSTRACI}

Neither of these orders is represented in the fossiliferous horizons of New York State. A single species belonging to Euphanerops longaevus Woodward is known from the Upper Devonic of Scaumenac bay, Quebec, and the Osteostraci are represented by four species of Cephalaspis [text fig. 5], two from the Lower and two from the Upper Devonic of British America.

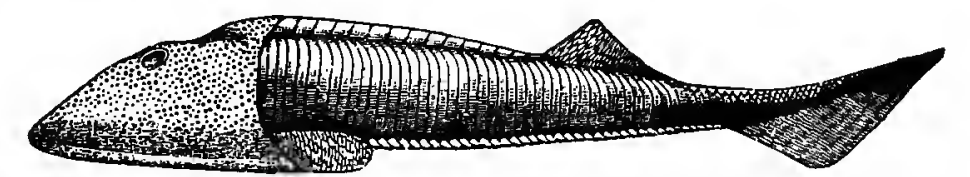

Fig. 5 Cephalaspis murchisoni Egerton. Siluric and Devonic; Herefordshire. Lateral aspect, restored by Dr A. S. Woodward. $\times 1 / 2$

It has been claimed by Professor William Patten that the genus Cephalaspis is provided with a "fringe of jointed and movable appendages ( 25 to 30 pairs) along the ventral margin of the trunk," the structures commonly known as marginal scales being interpreted by him as swimming appendages or "fringing processes." $\quad$ Regarding these fulcralike scales it is even stated by this author that "there is little doubt that they are the antecedents of the lateral fold of vertebrates," although it is elsewhere remarked in the same paper that "whatever their significance may be, there is apparently nothing known in true fishes that is exactly comparable with them." . The original specimens upon which these conclusions were based were afterwards reexamined by Dr Gaskell, who declares positively that they display nothing in the nature of paired appendages, ${ }^{3}$ and $\operatorname{Dr}$ Otto Jaekel of Berlin is equally emphatic in his denial that the marginal scales of this genus are not precisely what their name implies. ${ }^{4}$ Hence it would appear that the antecedents of the lateral fold of vertebrates must be sought elsewhere than in the structures to which Professor Patten has called attention.

${ }^{I}$ On the Structure and Classification of the 'l'remataspidae. Am. Nat. rgoz. 36:388.

${ }^{2}$ On the Structure of the Pteraspidae and Cephalaspidae. Am. Nat. I903. 37:827-65. 3 Anat. \& Physiol. Jour. 1903. 37: 198.

4 Zeitschr. deutsch. geol. Gesellsch. 1903. 55:84; cf. also Science. n. s. 1904. 19:703. 


\section{Order ANTIARCHA}

The Devonic Antiarcha possess a much more complex system of dermal plates than other groups of Ostracophores, and are provided with a pair of singularly jointed armored appendages, usually movable, evidently serving as organs of progression, and totally unlike the limbs of other vertebrates. The head and body shields are always movably articulated, both being traversed by well defined sensory canals; and the bone structure is dense, though with vascular cancellae in the middle layer of the more thickened plates. The external ornament always consists of tubercles and coarse rugae. At least one membranous dorsal fin is present, and in Bothriolepis there are two, according to the most recent accounts. The tail, either naked or scaly, is furnished with a large membranous caudal fin of genuinely heterocercal form.

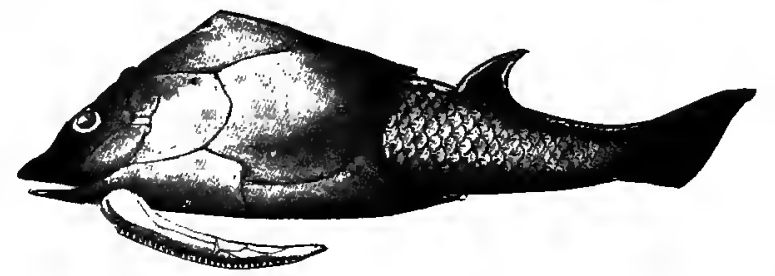

Fig. 6 Pterichthys cestudinaris Agassiz. Lower Old Red sandstone; Scotland. Lateral aspect, restored by Dr R. H. Traquair. $\times 1 / 2$

The forms belonging to this order are included within a single family, the Asterolepidae, sometimes, but incorrectly called the "Pterichthyidae." The typical genus, Pterichthys [text fig. 6], is not known to occur in this country, but the Upper Devonic Bothriolepis, which differs from Pterichthys principally in its longer appendages, scaleless tail, and various details of the body armor, is found both in the eastern part of North America and in Colorado, four species having been described in all. Asterolepis itself appears to be represented by a single postero-dorsal plate occurring in the Chapman sandstone of Aroostook county, Maine, the accompanying invertebrates indicating a lowermost Devonic horizon. This species, described in the sequel under the name of A. clarkei, in honor of the present New York State Geologist, is noteworthy for continuing the 
history of Asterolepids back over a longer time interval than has previously been known for this group. The so called "Astraspis desiderata" of Walcott, from the Lower Siluric of Canyon City, Col,, by some conjecturally referred to the Asterolepidae, is of extremely doubtful position.

\section{Family ASTEROLEPIDAE}

Head and body covered with dermal plates which are externally sculptured and tuberculate, the dorsal and ventral shields of the trunk firmly united by the lateral plates. Orbits very closely approximate, separated by a loose interorbital median plate. Position of the nasal organs not definitely known. One pair of paddlelike appendages, completely incased in osseous plates, and articulated by a complex joint with the anterior ventrolateral plates of the trunk. Sensory canal system well developed. Tail either naked or scaly; one or two dorsal fins, and a completely heterocercal caudal.

To form an adequate conception of the creatures indicated by numerous fragments of Asterolepid armor from the Upper Devonic of New York and Pennsylvania, it is necessary to pay particular attention to recent work that has been done in the investigation of Scottish and Canadian species. As has already been observed, the principal advance that has been made within late years is owing to the researches of Dr R. H. Traquair of Edinburgh, Professor William Patten of Dartmouth, and Dr Otto Jaekel of Berlin, their results being scattered through a very considerable number of papers. Without doubt the most notable contribution, and at the same time one of the most authoritative, is Dr Traquair's Monograph on the Asterolepidae, still in course of publication by the Palaeontographical Society of Great Britain. As students who have not access to special libraries can hardly be supposed to be familiar with the parts of this work already published, we shall probably do well to present here a condensed account of the Asterolepid organization, taken almost verbatim from the Scottish author's descriptions. Acknowledgments are due to the same source for the accompanying text figures of Pterichthys and Bothriolepis; and we are also indebted to 
Professor Patten for the restoration of the latter genus shown in text figure I 2.

General organization. Before entering into a description of individual forms, it is first of all necessary to understand the general structure of an
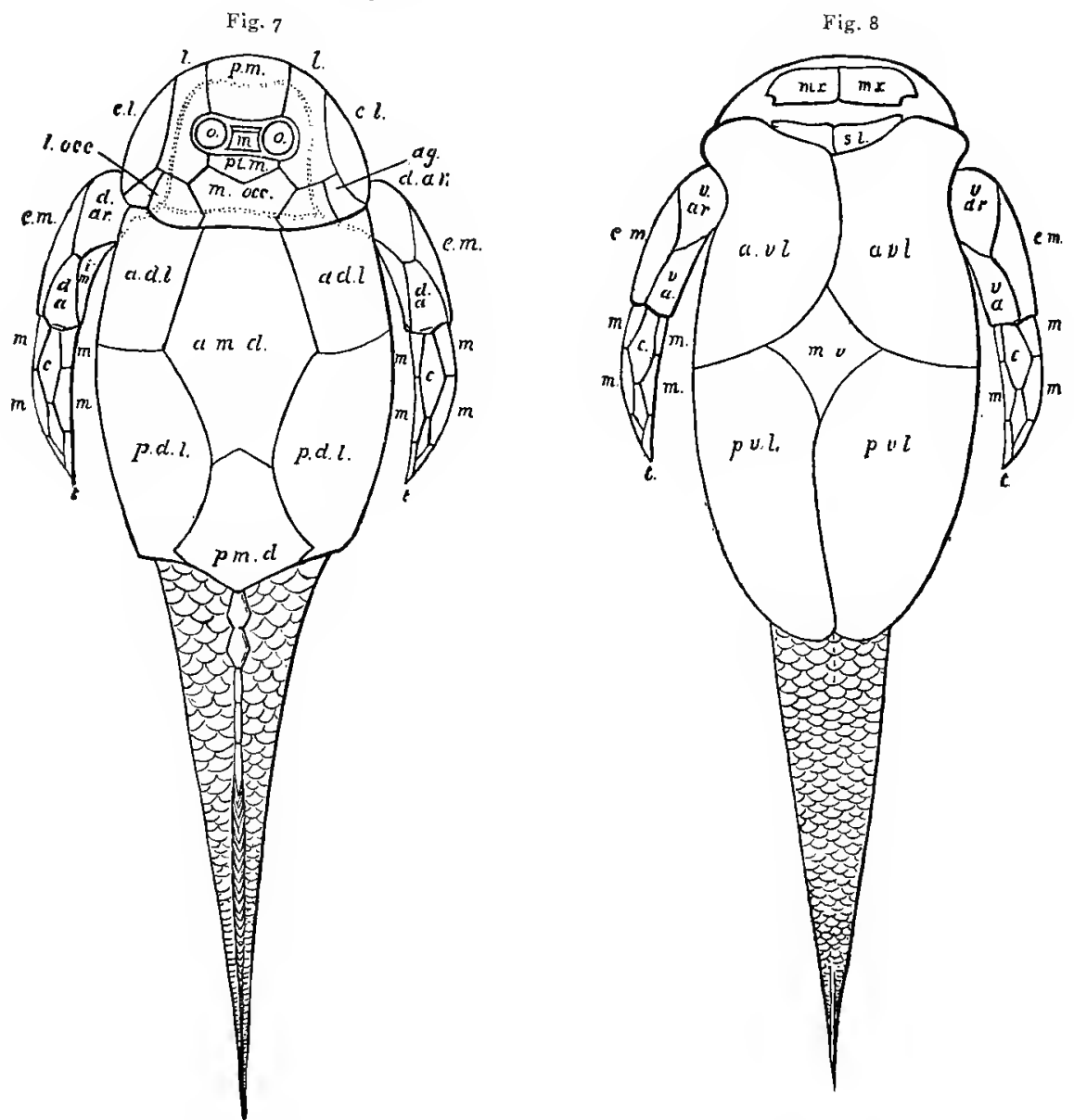

Fig. 7 Restored outine of Pterichthys milleri Agassiz; dorsal aspect. $x 3 / 4$

Fig. 8 The same from the ventral aspect. $x 3_{*}^{*}$ (Both figures after Traquair)

Asterolepid, and to know the names by which the various parts found in the fossil state may be distinguished. For this purpose it is well to take Pterichthys, as being the genus best known in its entirety, if not in every manner of detail.

The body armor consists of osseous plates closely fitted together, 
closed above, below, and at the sides, but open in front for the head, and behind for the tail. The head is covered almost entirely by a dorsal shield, formed also of plates united by suture. The two pectoral limbs consist also of plates similarly united, and are internally hollow so far as their remains in the stone are concerned.

The head shield [text fig. 7] is semielliptical in shape, rounded in front and truncated behind, where it joins the system of body plates. In the center it shows a transverse aperture, the median opening or orbit, slightly contracted in the middle and expanded at each of its rounded sides. This opening is in perfect specimens filled up by at least three other plates,

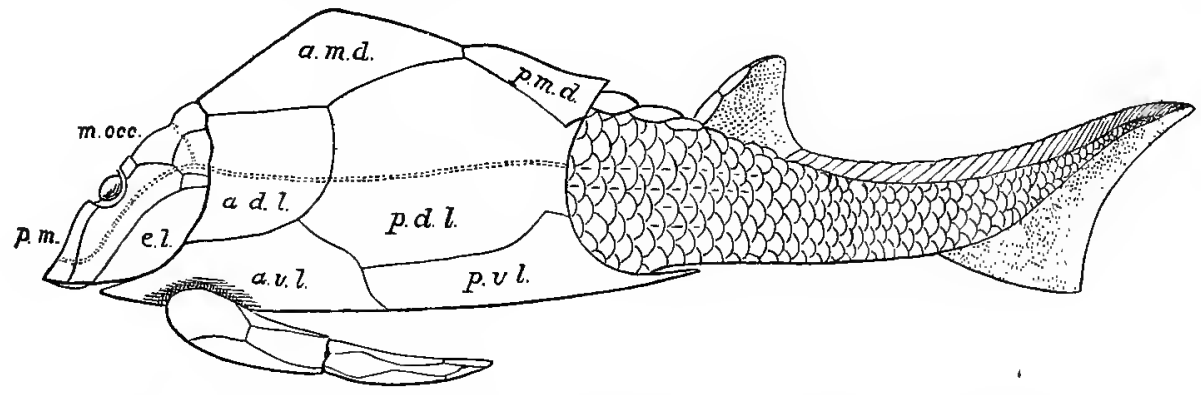

Fig. 9 Restored outline of Pterichthys milleri Agassiz; lateral aspect. x 3/4 (After Traquair)

which, being loose, are usually lost. Of these, one is in the center, quadrate in shape, but with concave outer margins, and may be called the median or pineal plate $[m]$, as it shows on the internal aspect a shallow rounded pit, pointed out by Dr Smith Woodward as probably the impression of the pineal body. This is by its outer concave margins in contact on each side with a rounded convex ocular plate [o], indicating certainly the position of the eye, but whether or not due to an ossification in the sclerotic is doubtful. [In Bothriolepis the orbits have two sclerotic plates each.] The nuchal region is occupied by a large plate, the median occipital [ $m$. occ.], shaped something like the conventional royal "crown," but without the pinnacle in the center. In front of this and immediately behind the median opening is a smaller plate, the postmedian $[p t . m$.$] ; while$ between the anterior margin of that opening and the front of the cranial 
shield is one of larger size and somewhat quadrate shape, the premedian $[p . m$.$] . Two large paired pieces, the lateral plates [l], one on each side,$ bound the median opening laterally, and also extend to the front of the shield, behind which, and forming part of the hinder margin of the buckler external to the median occipital, are two other paired plates, the lateral occipital [l.occ. $]$ and the angular $[a g]$.

The upper and lateral aspect of the cranial shield is now completed by a plate on each side, which is only loosely articulated in Asterolepis and Pterichthys, though firmly sutured in Bothriolepis. This is the extralateral [e. l.] or opercular plate, as it has also been called by some writers.

On the lower aspect of the head and close behind the anterior margin of the shield are two transversely oblong plates [mx.], right and left, the position of which was first determined by Whiteaves in Bothriolepis, ${ }^{\mathrm{x}}$ an observation corroborated by Smith Woodward." These plates must have been situated in front of the mouth, and may therefore be termed, at least conventionally, as maxillae. There can be no doubt that they were similarly placed in Pterichthys ("mental plates"), and in Asterolepis they were designated maxillae inforiores by Pander. Close to the postero-external angle of each of these plates there is a rounded notch, considered by Smith Woodward in Bothriolepis as possibly indicating a nasal opening. ${ }^{3}$

The anterior part of the trunk is incased in a boxlike armoring, nearly flat below, and vaulted above. It is composed of 13 plates, of which 3 are median and 10 paired, and these are united with one another by overlapping sutures, a marginal band along the internal surface of the overlapping plate being excavated to fit on to a correspondingly excavated band along the margin of the outer surface of the plate overlapped.

On the upper surface we see the anterior and posterior median dorsal

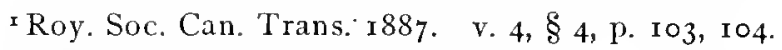

${ }^{2}$ Geol. Mag. Dec. 3, I 892 . 9:484.

3 This notch is somewhat differently placed in Bothriolepis, being fair on the outer margin of the plate instead of at its postero-external angle. Patten interprets the plates here called maxillae as mandibles. 
plates $[a . m . d$. and $p . m . d$.$] placed one behind the other in the middle of$ the back; passing down also on the sides are the anterior and posterior dorsolaterals $[a . d . l$. and $p . d . l$.$] . On the under surface, and also taking$ part in the formation of the sides are two pairs of plates, the anterior and posterior ventrolaterals $[a . v . l$. and $p . v . l$.$] , of which the anterior requires$ especial attention, as to it the pectoral $\operatorname{limb}$ is articulated. Near the anterior extremity of this plate, on the outer aspect and close above the angle which separated the lateral from the ventral surface, is a shallow excavation, from the bottom of which rises a peculiar process resembling a thick walled cup or helmet, whose hollowed out "mouth" points outwards, and also somewhat backwards and downwards, the cup itself being fixed by a stout ridge which traverses the containing hollow from behind forwards and also slightly downwards. This may be called the brachial process ("helmet-process" of Pander) as it is grasped by the two articular plates of the upper arm, and thus forms the brachial joint. Immediately behind this brachial process is a small oval aperture, the brachial foramen, perforating the brachial fossa from the interior, and which no doubt served to convey to the arm the blood vessels and nerves required for its supply.

The ventral surface of the carapace is completed by the median ventral plate $[m . v$.$] in the center, and in front by two very small semilunar plates$ [s.l.], each of which occupies a space cut out from the inner half of the anterior margin of the antero-ventrolateral, and is in contact in the middle line with its fellow of the opposite side. In Bothriolepis these last mentioned plates seem to be represented by a single median one.

Each of the hollow arms or brachia is divided by a transverse elbow joint into two segments, proximal and distal. The proximal segment or upper arm is trigonal in transverse section, becoming more flattened towards the elbow, and shows three surfaces, a dorsal slightly convex, a ventral flat, and a somewhat concave internal one, the latter fitting on to the side of the carapace when the arm is flexed. The proximal extremity of the arm is formed by two articular plates $[d . a r$. and $v . a r$. ], dorsal and ventral, whose rounded and hollow proximal expansions grasp between them the brachial 
cuplike process of the antero-ventrolateral plate of the body. These plates are consequently not in apposition at the joint, but are separated by an interval or slit, which contains and moves on the ridge attaching the brachial cup to the bottom of its fossa; and this interval is closed internally by the internal articular plate, and externally by the upper narrow extremity of the external marginal. ${ }^{x}$ The internal articular plate [i.ar.], placed right on the inner surface of the arm below the joint, is not seen in these figures; its free upper margin is concave, forming a rounded notch, over which the nerves and nutrient vessels of the appendage must have passed. The external marginal $[e . m$.$] forms the whole of the outer border of the upper$ $\mathrm{arm}$, and has nearly opposite to it the smaller internal marginal $[i . m$. $]$, while dorsally and ventrally this part of the limb is completed by the dorsal and ventral anconeal pieces $[d . a$. and $a \cdot a$.$] .$

The distal portion of the limb, or lower arm, is more flattened, and shows a dorsal and ventral surface, two sharp margins, external and internal, and a sharp apex or point. The ventral surface, and presumably the dorsal as well, is composed of two central pieces $[c]$, and six marginals [ $m]$ three of which are external, and three internal. It is the distal marginal on the inner side which forms the acute point or apex of the appendage, as first noticed by Jaekel.

The elbow joint is somewhat complicated. Each upper marginal of the lower arm is furnished above with an articular process, which is received within the lower extremities of the internal and external marginal plates respectively of the upper part of the limb. Then, on the other hand, each anconeal plate, dorsal and ventral, of the upper arm has a small flat articular process below, which fits into a slit on the outer surface of the upper extremity of the corresponding upper central of the forearm. It is hard to say how much movement could have been here allowed, but from the form of the joint it seems probable it was limited to a slight flexion and extension, and possibly only in the horizontal plane, as in the case of the shoulder.

' In Bothriolepis, however, the slit is completed externally by the two articular plates coming together above the external marginal. 
The tail (in Pterichthys) is covered with small, rounded, slightly imbricating osseous scales, which are arranged in longitudinal rows, and also in transverse bands. On the dorsal aspect behind the carapace there is a small median fin. Along the dorsal margin the scales are different in shape from those on the sides; in front of the fin they are in the form of a few narrow longitudinal median plates; behind it they are elongated and imbricating, like the fulcra or $\mathrm{V}$-shaped scales along the body prolongation of the tail of a Palaeoniscid fish. The dorsal fin is triangular, acuminate, and covered with small scales, no distinct "rays" being seen; and along its anterior margin some prominent elongated scales are placed, producing an appearance which has been mistaken for a spine. The hinder extremity of the fish is formed'by a completely heterocercal caudal fin, the body axis curving upwards as a pointed and slightly arched prolongation, and giving origin below to a fin expanse which is triangular in form, or slightly excavated behind, but not bilobate.

On the body and head there was a well marked lateral sensory canal system, indicated by grooves on the external surfaces of certain of the osseous plates, which grooves have often been mistaken for sutures, especially those on the cranial shield. On each side the lateral groove passes from behind forwards over the posterior and anterior dorsolateral plates, and thence on to the external occipital, where it at once bifurcates, a transverse branch passing across the median occipital to join its fellow of the opposite side. The main groove then runs forward on the lateral cranial plate, and arriving in front of the median opening it bends inwards to join the opposite groove on the premedian plate; a slightly different arrangement, however, is seen in Bothriolepis, as we shall see when that genus comes to be specially considered.

Genus Asteroceprs Eichwald

Definition. Median dorsal plate overlapping both the anterior and posterior dorsolateral plates. Arms shorter than the system of body plates; articular plates of the upper arm scarcely meeting externally over the 
external marginal. Postmedian plate of the head large and broad, excluding the median occipital from the margin of the orbit; premedian plate notched in front; extralateral plate loosely articulated with the rest of the cranial shield. Superficial ornament consisting of raised tubercles with stellate bases, which may be sometimes confluent. Lateral line system on the head connected by two commissural canals, a posterior one crossing the hinder part of the median occipital, and an anterior one crossing the premedian plate in front of the orbit. Tail unknown.

The characters of this genus, so far as known, do not differ from those of Pterichthys except as regards the mode of articulation of the anterior median dorsal plate, and in the arrangement of the terminal plates of the pectoral appendage. No specimens of Asterolepis have yet been discovered however which show the tail. Like Bothriolepis this genus has hitherto been supposed to be confined to the Upper Devonic, but the species immediately to be described proves that its geological antiquity is almost equal to that of Pterichthys. ${ }^{\text {. }}$

Asterolepis clarkei sp. nov.

Plate 7, figure 7,8

An imperfectly definable species, known only by a unique example of the posterior dorsomedian plate, which is about two thirds the size of that in A. $\mathrm{maxima}$, and exhibits the characteristic features of the genus. The plate is steeply arched from side to side, the slopes uniting mesially in a longitudinal carina along which the tubercles are densely crowded, and in part overlapping. Elsewhere the surface is covered with relatively coarse, conical nonstellate tubercles, which are rarely confluent, but tend to become arranged in concentric fashion over the anterior portion of the

I That is to say, on the assumption that the obscure fragnents from the Siluric of the Baltic provinces described by Pander as P. elegans, P. harderi, and P. st riat us properly belong to this genus. 'The species which have received these names are regarded as possibly founded upon fragments of Asterolepis ornat a by E. von Eichwald, Lethaea Rossica, I860, I: I507. Portions of Asterolepidlike appendages have also been described by Professor Patten from the Siluric of Oesel, but are referred by him with very slight probability to Tremataspis amongst the Osteostraci, in which such organs are unknown. ["On the Appendages of Tremataspis." Am. Nat. 1903. 37:223-42.] 
plate. Abruptly truncated in front, and with linear lateral margins in the anterior half, the posterolateral borders of the plate converge toward the hinder extremity in a gently undulating curve. The under internal surface of the plate is smooth without either a longitudinal ridge, pits or transverse folds, such as sometimes occur towards the posterior end in other species. The extreme width of the plate is slightly in excess of the total length, which amounts to 4 centimeters in the type specimen.

Owing to the favorable state of preservation of this interesting specimen it is possible to examine all of its characters. By a blow of the hammer, which broke open the matrix, a portion of the bone substance was splintered into fragments and lost. The remaining pieces, however, were carefully collected, cemented together and embedded in a plaster mold which was prepared from the impression left in the rock by the inferior surface of the plate. Similarly, an impression of the tuberculated external surface is preserved in the opposite counterpart. The distinctive characters of the plate, which consist in its highly elevated form, prominent carina and nature of the superficial ornament, are well illustrated in the figures that are given of the bone itself and the impression of its inferior surface.

The type of the species was collected from the sandstone beds exposed on the Chapman Plantation in Aroostook county, Maine, sometimes referred to as the Chapman sandstone. The invertebrate species accompanying this fish constitute a fauna of early Devonic age, as abundantly confirmed by the complete elaboration of the species." The type specimen of $\mathrm{A}$. clarke $\mathrm{i}$ is preserved in the New York State Museum.

Formation and locality. Chapman sandstone (Lower Devonic); Chapman Plantation, Aroostook county, Me.

x Science, Dec. 28, I90I; Am. Ass'n Adv. Sci. Proc. igor.

According to Clarke the evidence indicates an assemblage having a strong element of affiliation with the Coblentzian (Lower Devonic) of the Rhine and certain identities with the Helderberg and Oriskany of New York. This restudy of the fauna shows no dependable relationship to the Siluric. 


\section{Genus вотнRIOLEPIs Eichwald}

Definition. Premedian plate of head shield not notched in front; postmedian small, not excluding the median occipital from the posterior boundary of the orbit; extralateral, if present, small and narrow. Posterior commissural canal of head shield formed by a V-shaped groove, the apex of which is situated on the median occipital, and the anterior termini in about the center of the lateral plates. Anterior dorsomedian plate overlapping the antero-dorsolateral, but overlapped by the postero-dorsolateral plate. Pectoral appendages at least as long as the armored trunk, segmented into a distal and proximal portion, the latter being much larger than the former, which is narrow and tapering; marginal scutes of the proximal portion meeting mesially, with a minute anconeal element only on the dorsal aspect; articular plates in contact for some distance above the external marginal on the outer aspect; marginal and central scutes of distal portion more numerous than in Pterichthys. Tail naked; two dorsal fins.

A knowledge of the structure of this genus being indispensable for a correct understanding of the group, it is not surprising that the magnificently preserved specimens of B. can adensis, from the Upper Devonic of Quebec, should have invited the most searching investigation on the part of palaeichthyologists. The Canadian material is certainly unrivaled for exhibiting finer anatomical details, and but for the information so derived it would be difficult to interpret the poorly preserved remains occurring elsewhere in this country and in Europe. Bothriolepis is regarded as the characteristic Asterolepid genus of the estuarine aspect of the Upper Devonic, and is represented by four American, and some half dozen foreign species in strata of that age. 


\section{Bothriolepis canadensis Whiteaves}

Text figures ro-12

r880 Pterichthys (Bothriolepis) canadensis $J$. F. Whiteaves. Am. Jour. Sci. [.3] 20: $13^{2}$

188r Pterichthys (Bothriolepis) canadensis J.F Whiteazes. Can. Nat. n. 5. $10: 26,28$

I885 Bothriolepis canadensis E. D. Cope. Am. Nat. rg: 290

I 887 Bothriolepis canadensis E. D. Cope. Origin of the Fittest, p. 323, fig. 62

I 887 Pterichthys (Bothriolepis) canadensis J. F. Whitcaves. Roy.

Soc. Can. Trans. v. 4, $\S 4$, p. IoI, pl. 6-9

I888 Bothriolepis can adensis R. H. Traquair. Geol. Mag. [3] 5:509, and

Ann. Mag. Nat. Hist. [6] 2: 496, pl. I 8, fig. 6

I889 Bothriolepis canadensis J.F. Whiteaves. Roy. Soc. Can. Trans. v. 6,

$\S 4$, p. 9 I

I 892 Bothriole pis can a densis $A$. $S$. Foodzuard. Geol. Mag. [3] g: 484

r 893 Bothriolepis can a densis $H$. S. Wiliiams. Am. Jour. Sci. [3] 46:286, text fig. $3-5$

r 898 B othriolepis canadensis E. D. Cope. Syllabus of Lectures on Vertebrata, p. I6, fig. 2

I 898 Bothriolepis can adensis $A$. S. Woodward. Outlines of Vertebrate Palaeontology, p. I4, fig. I3-I5

I904 Bothriolepis can adensis IV. Patten. Biol. Bul. 7: I 3 , fig. I-6

I904 Bothriolepis can adensis $R$. H. Traquair. Fishes Old Red Sandstone, Monogr. Pal. Soc. 2, pt 2, p. Io9, fig. 57-59

A species of moderate size, the head and trunk attaining a length of about o.I 7. Head much broader than long, about one half as long as the dorsal armoring of the trunk; trunk broadly ovate, the sides overhanging the narrowly ovate ventral surface. Proximal segment of pectoral appendages broad, but elongated; distal segment relatively slender, only slightly ornamented, two thirds as long as the proximal segment; outer and inner margins coarsely serrated. Anterior median dorsal plate as broad as long, more or less keeled in its posterior two thirds; posterior median dorsal plate longitudinally keeled, the keel rising to a slight eminence near the posterior margin. Ornament consisting of fine rounded tubercles fused into nodose, vermiculating ridges; those near the edges of the dorsal plates often displaying concentric arrangement. (Woodward) 
The following detailed account of the structure of this extremely important species has been compiled chiefly from the recent papers of Traquair and Patten, cited in the above references to the literature.

The head shield occupies nearly one third of the entire length of the armoring, and shows, on the upper surface, an orbital opening which is smaller and further back than in Asterolepis. The median occipital plate [text fig. Io $m . o c c$.] has its lateral margin more perpendicular to the pos-

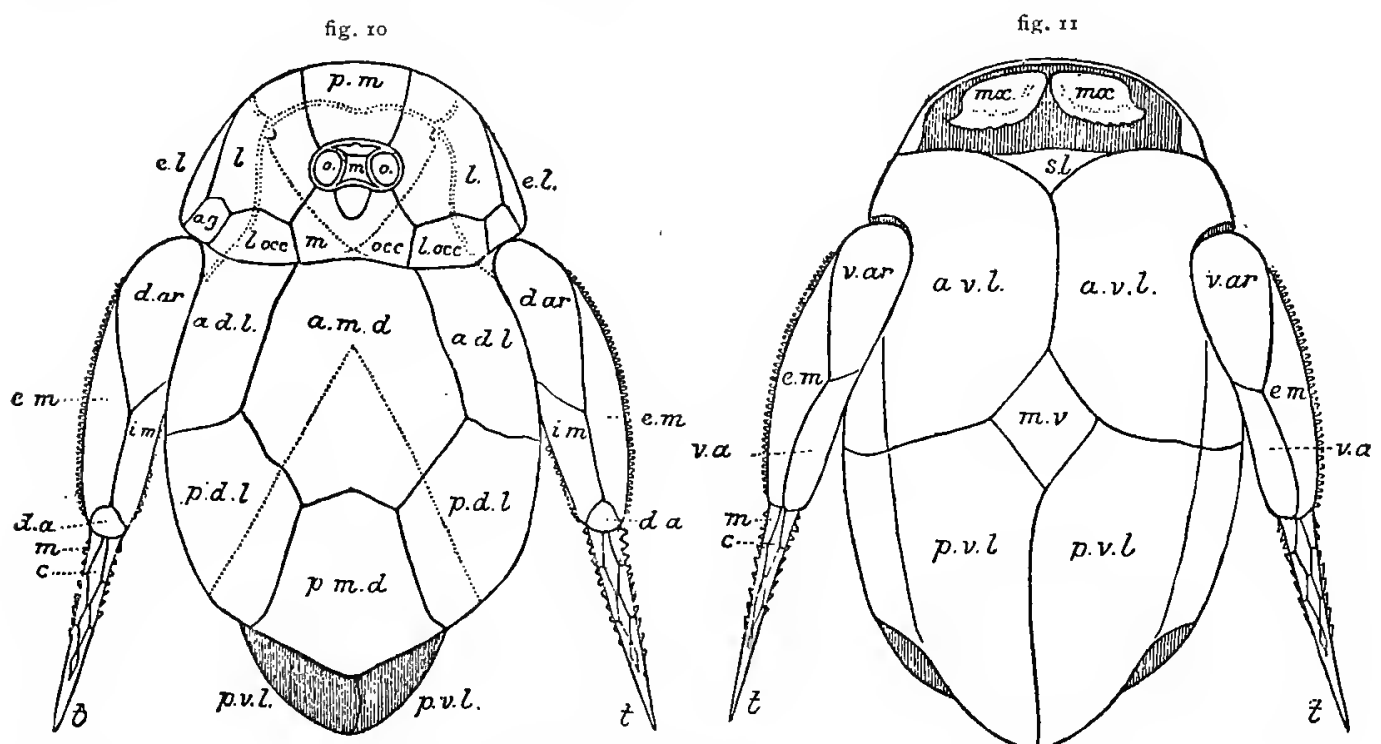

Fig. ro Bothriolepis canadensis Whiteaves. Upper Devonic; Scaumenac bay, Province of Quebec, Can. Restoration of dorsal aspect, slightly modified from Traquair

Fig. II Restoration of ventral surface of same, slightly modified (After Traquair)

terior one than in the last named genus; its anterior aspect shows not merely a shallow reentering angle for the postmedian plate, but a deep semielliptical notch or excavation, on each side of which it takes part in the formation of the posterior boundary of the orbit. Consequently the postmedian plate is small, entirely received in the aforesaid notch of the median occipital, and thus excluded from joining the laterals as in Pterichthy's and Asterolepis. The lateral occipitals [l.occ.] and the angular [ag] do not call for any special comment, but the laterals $[l]$ are much broader than in Asterolepis, while the extralaterals [e.l.] are verv small, narrow, and pointed in front. 
The orbital opening $[0]$ is, as already mentioned, small compared with that of Asterolepis, and, moreover, its anterior margin shows scarcely any reentering flexure. Its right and left portions are almost completely filled by a system of sclerotic plates, the two inner ones being very considerably larger than the two outer, and the middle portion is covered by two loosely attached plates, namely the median or pineal [ $m]$, and a very narrow T-shaped plate $x$ (called by Patten the "ethmoid") close in front of it. From the center of this narrow plate, as shown by Whiteaves and confirmed by Patten, a small linear process with expanded lower extremity passes down perpendicularly into the interior of the head, almost reaching a thin transverse shelf of bone which projects downwards from the under side of the premedian $[p . m$.] The space thus partitioned off beneath the premedian is interpreted by Patten as an "olfactory chamber," and certain conjectures are hazarded by him as to the course of the olfactory nerves, which will be referred to presently. The median plate of the ocular opening is nearly perforated by a deep pineal foramen, similar to that occurring in Pterichthys, and often indicated by a low tubercle on the external surface. Two other pits, shallower than the first and without any external indications of their presence, are symmetrically placed behind it on the under side of the small postmedian plate. The unpaired pit is in all probability to be regarded as the impression of the pineal body, but it is difficult to imagine what may have been the function of the posterior pair. Analogy with all other vertebrates does not permit us to entertain the suggestion, put forward with some confidence by Professor Patten, that these three pits are of similar nature and indicate the presence of a triocular median eye. ${ }^{x}$

A matter of absorbing interest is the arrangement of mouth parts in this species, now very satisfactorily known. Beneath the head shield at its front extremity [text fig. I I $m x$ ] there is observed a pair of thin, concave plates of bone with free median and posterior margins, the latter being sharply beveled and serrated. These plates are quite similar to those called the maxillae in Pterichthys [text fig. $8 \mathrm{mx}$ ], but are less extensively

${ }^{1}$ New Facts Concerning Bothriolepis. Biol. Bul. 1904. 7: 12 I. 
in contact mesially, and are notched at the anteroexternal instead of at the posteroexternal angles. The greater part of the exposed surface of each plate is feebly rugose and marked by a sharply bent sensory canal, thus recalling well known Arthrodire conditions, and confirming their interpretation as maxillae. In the majority of specimens, these plates, and also the much more delicate pair of mandibular elements, are more or less displaced, but this circumstance alone furnishes no reason for supposing that the two pairs did not work directly against each other, or that the right and left halves of either pair were capable of independent motion, as in Arthropods. Neither are we compelled by the form of the mouth parts to make any anomalous suppositions as to their movements or relations to one another, although it is evident that they are merely dermal ossifications, and therefore of different nature from the jaws of higher vertebrates.

The pattern of the cephalic sensory canal system is considerably different from that in Asterolepis and Pterichthys. No transverse commissure unites the lateral canal of each side across the occipital plates; but in front, just at its incurved flexure on the lateral plate, a conspicuous branch is given off, which runs forwards and outwards to the margin of the shield, being very likely continuous with that on the maxillary plates on the lower side of the head shield. On the median occipital two fainter canals are observable, forming an angle with each other but not always uniting behind, and extending outwards and forwards over the lateral plates until they become confluent, or almost confluent, with the lateral canal near its central point of flexure. Near the same point, on the inner side of the main groove, a small ear-shaped mark is often, but not always to be seen. The main groove is continued nearly parallel with the periphery until it reaches the center of the premedian plate, where it is sometimes interrupted for a short distance.

The articulations of the body plates are as in Pterichthys, the anterior median dorsal $\left[\begin{array}{lll}a . & m . & d .\end{array}\right]$ overlapping the antero-dorsolateral $\left[\begin{array}{lll}a . & d . l .\end{array}\right]$ of

'Professor Patten, however, insists that these plates are mandibular, and that the smaller, S-shaped pair are maxillary [loc. cit. p. I i 8 ]. 
either side, but being itself overlapped by the postero-dorsolaterals [ $p . d . l$.$] .$ On the under surface [text fig. 11 ] the place of the two semilunars of Pterichthys is filled, according to Professor Patten, by at least three pieces, the posterior margins of which are assumed by the same author to have been "freely movable in a dorsoventral direction, like an operculum." The course of the lateral sensory canals is exactly the same as in the body plates of Pterichthys, but in addition two shallow linear grooves diverge at a slight angle from about the center of the antero-dorsomedian plate, and extend across the postero-dorsolaterals.

The pectoral appendages are longer than the dorsal aspect of the body armor, and even pass beyond the termination of the ventral surface. The proximal portion is also longer than the distal, though the proportion seems to vary; roughly speaking, however, the difference between the two portions is less than one third of the longer. The proximal portion is, like that of Asterolepis, trigonal in transverse section, and the plates of which it is composed are also similar in number and arrangement, save that the

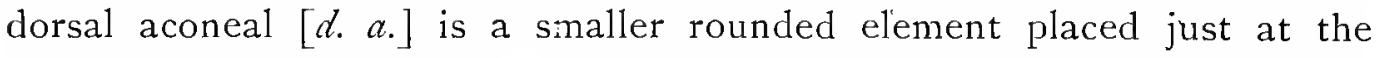
"elbow" joint, whereby the external and internal marginals are allowed to come together for a considerable distance between it and the distal extremity of the dorsal articular [d.ar.]. The two articulars, as noted in the generic diagnosis, meet together on the outer aspect over the external marginal; this relation, however, is not always clearly visible in the Canadian specimens, though demonstrable in many fragments from Scotland and Russia. The lower or "fore" arm is slender and pointed, serrated along the external and internal margins, and composed of a greater number of pieces than in Pterichthys or Asterolepis.

For our knowledge of the trunk, caudal, and two dorsal fins in this species, which is the only one of the genus showing these features, we are indebted to the painstaking investigation of Professor Patten, who has presented the following preliminary account of his observations : ${ }^{2}$

'Structure of the Ostracoderms. Science. n. s. Ig03. I7: 489 .

${ }^{2}$ Biol. Bul, rgo4. $7:$ I I3. 
The trunk [text fig. I 2] was very slender and covered with a soft skin

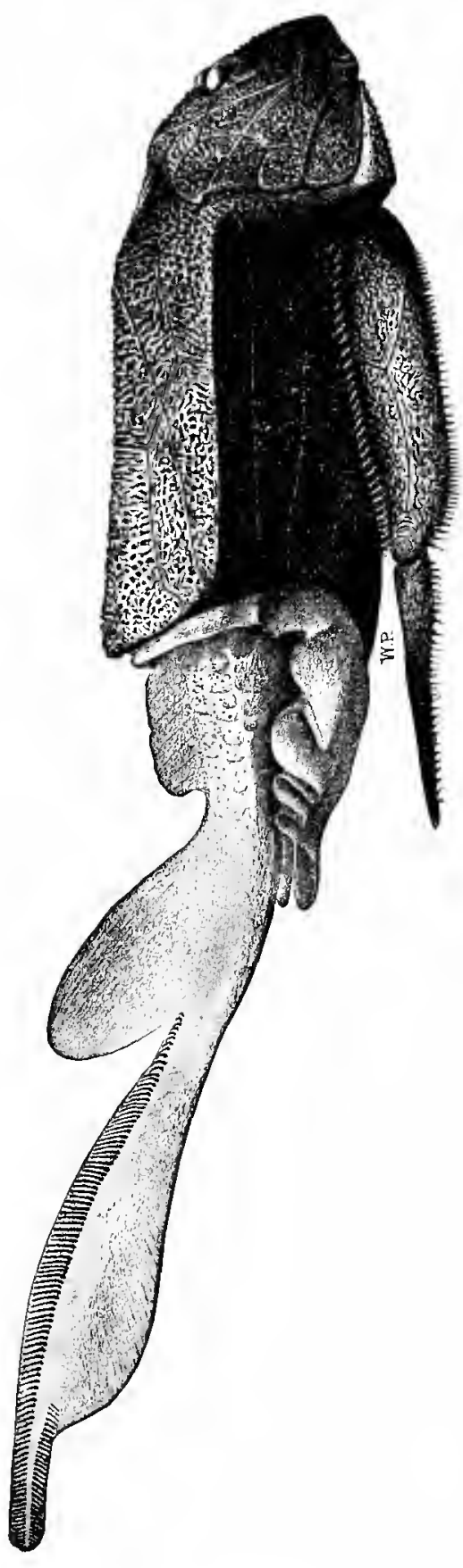
devoid of scales or of any other markings except those mentioned below. In spite of its delicate structure it is often only moderately compressed or distorted. In the region of the posterior dorsal, it may present a somewhat triangular cross-section, resembling that of Cephalaspis in a corresponding region, but without any traces of a lateral fold or of fringing processes [i. $c$, fulcra, or marginal scales of other authors].

A few small irregular plates, with the typical sculpture of the buckler, are embedded in the skin along the clorsal surface, inmcdiately in front of the anterior dorsal, and numerous minute ones are scattered irregularly over the flanks in the same recrion. One specimen shows indications of a lateral groove, and, dorsal to it, a few oblong folds suggrestive of segmentation.

The anterior dorsal fin is low and elon. gated, the posterior one very high and rounded. Both fins are often preserved with wonderful clearness, but show no other detail than a faint striation probably due to the presence of delicate subdermal rays.

The elongated tail, with its axis slightly curved, terminates in a narrow band. The dorsal marsin consists of a delicate mem. brane, strengthened by a row of curved rods lying close together and arranged with great regularity. The basal ends of the rods are swollen, and one is turned a little to the left, and the adjacent one, to the right of the median line. The rods extend on to the ventral marsin of the terminal band, into the ventral lobe. The latter is faintly striated like the dorsal fins. Its anterior ventral marrin appears to divide, as though it were continued forward into the lateral folds, although no such folds have been detected in the trunk region.

There are no indications whatever, either 
in surface views or in sections, of vertebral centra or arches, and the preservation of the specimens is so perfect that there is every reason to believe such structures, even if formed of cartilage only, were absent. Neither have we found any indication of a notochord, although one may infer from the outline of the trunk that a notochord was present. It was probably surrounded by a membranous sheath of no more consistency, if as much, than that in Amphioxus.

We may now return, finally, to a consideration of one or two doubtful matters. Neither on the dorsal nor ventral surface of the head region are there any certain indications of olfactory openings. It has.been suggested by Smith Woodward, however, that the rounded notch occurring at the external angles of the maxillary plates in Pterichthys and Bothriolepis may indicate the opening of a nasal sac, and it is indeed difficult to conceive what other function it could have subserved. Professor Patten offers no explanation of the notches in question, but advances the novel idea that the olfactory and orbital openings were confluent. The pineal plate and the $T$-shaped one in front of it, alongside of wnich the olfactory nerves are supposed to have passed according to Patten's conjecture, were capable of being moved forwards and backwards, coincidently with the sclerotics, the eyes and olfactory pits being opened by one set of movements, and closed by a reverse set. An awkward defect of such a contrivance, if it ever existed, is that the creature could not smell with its eyes shut. One might esteem it a doubtful advantage, also, that the same opening in the head shield should have served for both sight and smell. Possibly it is on this account that the ingenious author whom we have just quoted imagines that the eyes "were placed on short stalks attached to the margin of the orbits by flexible membranes. The lateral end of each stalk was convex, covered with a smooth shell, and could evidently be raised above the orbit or lowered into it." × Comment on these extremely fanciful hypotheses is unnecessary.

Formation and locality. Upper Devonic; Scaumenac bay, province of Quebec, Can.

IStructure of the Ostracoderms. Science. n. s. I903. I $7: 488$. 


\section{Bothriolepis nitida Leidy}

Plate 3, figure 4; plate 7, figure $\mathbf{r}$

I 856 Stenacanthus nitidus J. Leidy. Acad. Nat. Sci. Phila. Proc. 8: II; Acad. Nat. Sci. Phila. Jour. [2] 3: 164, pl. 16, fig. 7,8

$1856 \mathrm{Holoptychius} \mathrm{americanus} \mathrm{(pars)} \mathrm{J.} \mathrm{Leidy.} \mathrm{Ibid.} \mathrm{p.} \mathrm{I63,} \mathrm{pl.} \mathrm{17,} \mathrm{fig.} 4$

I889 B oth riole pis le idyi J. S. Netoberry. U. S. Geol. Sur. Monogr. I6: III, pl. I 8, fig. 2, pl. 20 , fig. $1-5$

I89 I Holonema rugosa E. D. Cope (errore). U. S. Nat. Mus. Proc. 14:456, pl. 3 , fig. 7

r 893 Bothriolepis canadensis H. S. Villitms (errore). Am. Jour. Sci. [3] p. 286 , text fig. 5

1899 B oth riolepis leidyi C. R. Eastman. N. Y. State Geol. I7th An. Rep't, p. 324

An imperfectly definable species known only by fragments of the dermal armor and appendages. Superficial ornament consisting of fine stellate tubercles fused into nodose vermicular ridges. Pineal plate relatively large and of semicircular outline. Form and general proportions of pectoral appendages as in the preceding species, except that only the external margin is serrated.

This species appears to have equaled, or even have exceeded the average of $\mathrm{B}$. c a n a d e n s is in size, and displays a similar ornamentation. The stellate character of the tubercles rarely appears in worn specimens, and the ornament is coarser in large sized than in smaller or younger individuals. As indicated by a fragment of an extremely large example belonging to the New York State Museum [pl. 7, fig. I], one that even surpasses Asterolepis $\mathrm{max}$ im a in size, the appendages were attached to the antero-ventrolateral plate considerably further back than is usual amongst other species. The proximal portion of the limb in this particular specimen has a width of no less than 2.4 centimeters. The "fore" arm of another specimen belonging to the same museum is shown in plate 3 , figure 4 , in which the pointed terminal portion is well preserved. Three central elements can with difficulty be recognized besides the terminal, in which case we should expect to find four marginals; but neither in this 
specimen nor in any previously figured appendage are their boundaries clearly discernible.

Only a few fragmentary examples of the head shield have thus far been obtained. One such belonging to the Museum of Comparative Zoology at Cambridge, Mass. is notable for having the orbital region well preserved, with the pineal element in place, and for exhibiting both external and internal (visceral) aspects of the postmedian plate. Two shallow rounded pits, similar to those that have already been observed in B. canadensis and Asterolepis maxima, but separated by a small, tumid T-shaped septum, occur in about the center of the latter plate on the inferior surface. The pineal plate is much larger than the corresponding element in other species, and is semicircular in outline, instead of quadratic. A tubercular swelling seen on the dorsal surface would seem to indicate the presence of a pineal pit beneath. No other plates remain in the orbital opening of the specimen in question.

The fact has already been noted by Newberry and Smith Woodward that in the groups of detached plates belonging to this species, the large anterior dorsal is more numerous than any of the others, its greater frequency being ascribed by these authors to sorting of material through current action during deposition of the sediments. One might suppose, also, that this plate was better able to withstand injury on account of the solidity imparted to it by the strong median keel running along the median line of the under side. At all events it is certain that the keelless posterodorsomedian plate is far less commonly preserved.

Formation and locality. This species occurs typically and in great abundance in the Catskill of Tioga county, Pennsylvania, but has been reported from but a single locality in New York State, along the line of the Ontario and Western Railroad between Merrickville and North Walton, in Delaware county. 


\section{Bothriolepis minor Leidy}

is89 Bothriolepis minor f. S. Netelerry. U. S. Geol. Sur. Monogr. I6: irz, pl. 20 , fig. $6-8$

IS9z Bothriolepis minor E. D. Cope. Am. Philos. Soc. Proc. 30:224

1899 Bothriolepis minor C.R. Eastman. N. Y. State Geol. r7th An. Rep't, p. 324 , text fig. 5

This species is readily distinguished from the preceding by its smaller size and very much finer ornamentation, the external surface being covered with fine, closely crowded, vermiculating ridges. Unfortunately, it is

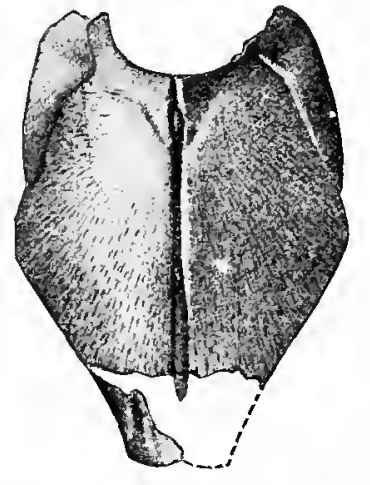

Fig, rz linthriolefisminor Newbery. Antero-dorsomedidn plate with denuded external ornantentution. Catskill situdstute; lelaware county, N. I. known only by detached plates, amongst which the head and appendages are excessively rare. The latter are of about the same relative proportions as in B. $\mathrm{n}$ it id a. Concerning the head shield it is stated by Cope that "one of the characters of the species is seen in the fact that the sensory groores of the median occipital plate do not extend to the smooth articular border, but are separated from it by a band of sculpture. The premedian plate is crossed by a groove which presents an abrupt loop backwards at the middle."

As is commonly the case in this class of remains, the antero-dorsomedian plate is of more frequent occurrence than any other, though seldom found entire. Its orientation may be easily determined by means of the $V$-shaped sensory canals which diverge from about the center of the plate, or, in case the superficial ornament is denuded, by means of the longitudinal keel which traverses the median line of the plate for about three fourths of its length. A specinen of this character is illustrated in the accompanying text figure.

Formation and locality. Chemung group of Bradford county, Pennsylvania, and Catskill of Delaware county, New York. According to Newberry, a species similar to this, and perhaps identical with it, occurs in the Deronic of Belgium. 
Bothriolepis coloradensis Eastman

I 904 B othriole pis coloradens is C. R. Eastman. Am. Jour. Sci. [4] i 8: 254, text fig. 2,4

This, the largest known American species of Bothriolepis, is chiefly interesting on account of its geographical and geological occurrence, and for the evidence it furnishes regarding Asterolepid distribution. Although the length of the appendages has not been determined in this form, the general configuration of the ventral surface, and particularly the lozengelike form of the ventromedian plate, sufficiently warrant its reference to this genus. Its relations seem to be rather with the Canadian than with either of the Chemung-Catskill species occurring in the eastern United States. Add to this the fact that no Asterolepid remains are known from the Upper Devonic horizons of the middle west, although other Chemung forms are present in abundance, it is difficult to trace the line of migration so as to connect the Rocky mountain species with those in New York and Pennsylvania. On the assumption that the former is a European immigrant, two other routes are available, one lying to the northward, by way of Canada, and the other to the southward, around the end of the Appalachian chain. A further discussion of this question may be reserved for a subsequent section of this memoir.

In the original description of this species, two figures were introduced for the purpose of comparison with Scottish specimens which bore the designation of Bothriolepis major, and were reputed to have been derived from the well known locality southward of Elgin. Recently, a more attentive examination of these specimens ' and of the matrix in which they are inclosed has led the writer to believe that they could not have been collected at Elgin, but most likely from the Upper Old Red sandstone of the immediate vicinity of Nairn. Now these Nairnshire plates, which in former years were universally known under the name of $\mathrm{Pter}$ -

The median ventral in particular is broader and more ovately lozenge-shaped than in Bothriolepis major, and the specimen shown with all the ventral plates in apposition is one of the best ever found of this species. 
ichthys major, have been found by Dr Traquair to belong to "a very different creature from the Pterichthys (Bothriolepis) major of the adjoining district of Elgin," and are determined by him as A sterolepis maxima. The same author further observes that "it is remarkable that while Asterolepis maxima is unknown in those strata round Elgin which are characterized by Bothriolepis major, not a single remnant of any species of Bothriolepis has ever been found in the Asterolepis-bearing becis at Nairn. Other fish remains are very rare in these beds, but such as I have obtained leads me to suspect that we have here to deal with quite a different fauna from that of the closely adjoining district of Elgin." Accordingly, the identification of the two figured specimens referred to should be amended so as to read "Asterolepis ma $\mathrm{x}$ im a, from Nairn."

Formation and locality. Elbert formation (Upper Devonic); Rockwood and Devon Point, Col.

\section{Class PISCES}

\section{Subclass ELASMOBRANCHII}

\section{Order PLEUROPTERYGII}

The only known representative of this order, and at the same time, as indicated by the condition of its paired fins and other features, the most primitive type of Elasmobranch yet discovered, is the Upper Devonic and Lower Carbonic genus Cladoselache. Amongst all fossil fishes this genus is regarded as furnishing the most important testimony in favor of the lateral fin fold hypothesis. In view of its extreme importance from a morphological and phylogenetic standpoint, it seems desirable to offer the following account of its organization, compactly drawn up by Smith Woodward:

The fish is elongated and round-bodied, with a short blunt snout and forwardly placed eye. The precise characters of the cranium are unknown: but the olfactory capsules are large, placed close together, and terminal. The mouth is also terminal, the upper and lower jaw being similar in shape and size, and supported by a slender elongated hyomandibular. The teeth are largest, longest, and most acutely pointed at the symphysis of the jaw, smallest and shortest at the angle of the mouth. The transverse series are closely apposed, and not separated as in the modern Chlamydoselachus; 
they are indeed tightly wedged together, and the cusps are frequently much abraded by wear. Every tooth has a principal cusp with variable smaller lateral cusps, and the broad base of each is overlapped by its successor behind. The number of gill arches is uncertain, but five are known, and the presence of one or two others is suggested by some specimens. The neural and haemal arches of the axial skeleton have been observed only in the caudal region, where they are short tapering rods of cartilage, bifurcated at the base and distinctly corresponding in number with the calcified remains of the muscle plates. Intercalary cartilages are wanting.

The small basal cartilages of the paired fins seem to be embedded in the body wall, and the unjointed radial cartilages extend directly outwards to the edge of the membrane. There are no claspers in the pelvic fins, and both these and the pectoral fins were probably mere balancers, directed somewhat downwards. Two low dorsal fins have been observed, both destitute of an anterior spine, ${ }^{x}$ but strengthened by simple cartilaginous rays extending to the edge of the fin membrane. No anal fin has been

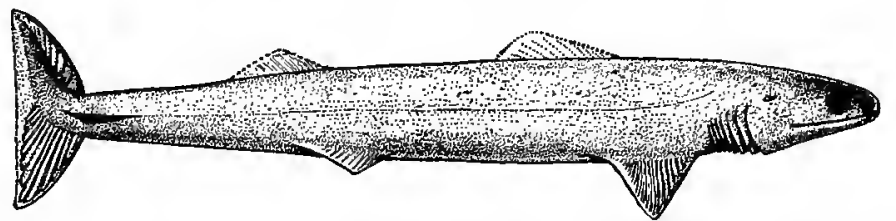

Fig. I4 Cladoselache fyleri Newberry. Cleveland shale (Upper Devonic); Ohio. Lateral aspect, anterior dorsal fin spine omitted, x r-zo (From Dean)

distinguished. The caudal fin [text fig. I4] is strongly heterocercal and very remarkable. The neural arches seem to persist even to the end of the upturned axis, directly supporting the thick radial cartilages of the superior lobe of the caudal fin. The dermal membrane of the inferior lobe of the caudal fin is supported by simple cartilaginous rays only in its lower portion where they extend quite to the margin. The eye is surrounded by a double series of small dermal plates; but the remainder of the fish is covered only with minute lozenge-shaped denticles, which are apparently not enameled. The latter are slightly enlarged at the angles of the mouth, where they approximate in size and shape to the smallest of the teeth. The lateral line extends along the trunk between two series of the shagreenlike granules, and was thus presumably an open canal. A short dermal expansion forms a horizontal keel on each side of the caudal lobe just in advance of its upturned end. The largest known examples measure nearly 2 meters in length.

We have said that this genus is looked upon as furnishing important

$x$ This statemenc requires to be amended, $D^{*}$ Dean having discovered at least one specimen in which the anterior dorsal fin is provided with a powerful Ctenacanthus like spine. 
support for the doctrine of the evolution of fins, which now ranks as a fairly well demonstrated principle. In the first place, it is important to bear in mind that the paired fins of Cladoselache are the oldest known structures of the kind which are clearly observable; and secondly, they approach more closely than any others to the hypothetical primitive type from which all paired limbs have been derived. Briefly stated, the lateral fin fold theory assumes that fishes originally possessed on each side of the body a continuous fold of skin, strengthened by parallel cartilaginous rods extending outwards from the body wall, this fold becoming subdivided into the pairs of pectoral and pelvic (ventral) fins as we know them in modern forms.

Now it has been shown by Dr Bashford Dean that in Cladoselache the paired fins were mere balancers with a more extended base line than is usual. The series of parallel cartilaginous rods, which in a primitive condition supported the lateral fin fold, exist practically unmodified in the pelvic fins, simply clustered and partly fused within the body wall of the pectoral fins. Dean, Cope, and others are of the opinion that there is a tendency in the pectoral fin for the hinder end of the row of basals to rotate outwards - a process which would reduce the point of attachment of the fin to what was originally its front angle. The outwardly turned row of basals would in this case correspond with the median axis of the well known paddle in Ceratodus and Pleuracanthus, and one may without diffculty conceive of a fringe of cartilaginous rays developing quite secondarily along the hinder border of this axis. Hence, as argued by Dean and Cope, the modern tribasal or dibasal shark's fin can not have evolved from the paddlelike "archipterygium," but these two kinds of fin must have arisen independently from the "ptychopterygium," as the arrangement has been appropriately termed by Cope. ${ }^{\text {T }}$

${ }^{x}$ For interesting discussions of this subject, one may consult the following: Mollier, S. Die paarigen Extremitäten der Wirbeltiere. I. Das Ichthyopterygium. Anatom. Hefte, 3: 1893; Dean, B. Contributions to the Morphology of Cladoselache. Jour. Morphol. r 894. 9: 87-114; $A$ new Cladodont from the Ohio Waverly. New York Acad. Sci. Trans. 1894. 13: 115-119; The Fin-fold Origin of the Paired Limbs, in the Light of the Ptychopterygia of Palaeozoic Sharks. Anatom. Anzeig. 1896. I1: 673-79; Woodward, A. S. The Problem of the Primeval Sharks. Nat. Sci. 1895. 6:38-43; Ibid. I892. I : 28-35. 
Cladoselache sp. ind.

Plate 8, figure ،

The few species of Cladoselache that are known have been found only in the Cleveland shale (Upper Devonic) and Waverly (Lower Carbonic) of Ohio. This statement is made, however, without taking into account the numerous teeth known as Cladodus, some of which may possibly belong to the Pleuropterygii. Under these circumstances it is interesting to note the undoubted occurrence of the genus in the Portage beds of western New York, as indicated by a well preserved pectoral fin belonging to the Buffalo Society of Natural Sciences. This was obtained a few years ago by $\mathrm{Mr}$ F. K. Mixer, of Buffalo, from a concretion in the Naples shale of Eighteen Mile creek, near the shore of Lake Erie, and was by him submitted to the present writer for examination. Later it was placed in the hands of Dr Dean for study, who has promised a more detailed description of it in connection with newly discovered Ohio material. We may therefore content ourselves at present with a mere indication of the occurrence of Cladoselache in a new horizon and locality, and with remarking upon the decidedly primitive condition of the fin. This is indicated by its acutely triangular, almost spinelike form together with the lack of crowding and concentration of the numerous rays. The apex is more acutely pointed than in any form hitherto described, and the radials, upwards of 70 in number, apparently extend inside the body wall. Characters of this nature are regarded by Dean ' ${ }^{\text {a }}$ as suggestive of Acanthodian affinities, but it appears tolerably certain that the two types of fins can have but a very remote connection. The reasons for the latter view are thus stated by $\operatorname{Dr} \mathrm{A}$. S. Woodward : ${ }^{2}$

In conclusion, one word of protest against the American idea that the paired fins of Cladoselache can be compared with those of an Acanthodian. We venture to maintain that these fins are fundamentally different in every respect. In Cladoselache the cartilages of the internal skeleton are well developed and support the whole fin membrane; in Acanthodians, what-

I The Fin-fold Origin of the Paired Limbs, in the Light of the Ptychopterygia of Palaeozoic Sharks. Anatom. Anzeig. I896. I I: 678 .

2 The Problem of the Primeval Sharks. Nat. Sci. r895. 6: 42 . 
ever view we may adopt as the naming of the parts, these cartilages are as much reduced as in a modern herring. Dr Dean speaks of the "radials" of Cladoselache as if, by fusion, they might readily become a fin spine like that of the Acanthodian Parexus; but the former are cartilage and endoskeletal, the latter is merely the ordinary dentine and therefore presumably exoskeletal. The problem of the primeval sharks continues to present endless difficulties, but these are only multiplied by such comparisons. In the present writer's opinion, the pectoral of Cladoselache is more remotely connected with that of the Acanthodians than is that of a modern Siluroid with the pectoral of the Devonic Holoptychius. Everything still tends to show that the very highest Elasmobranchs lived simultaneously with almost the lowest in late Paleozoic times; while sharks and skates nowadays are a comparatively degenerate race.

Formation and locality. Naples shale (Portage beds); Eighteen Mile creek, near Buffalo, N. Y. A tooth of an undetermined species of Cladodus is also recorded by J. M. Clarke, ${ }^{\mathrm{I}}$ from the Chemung beds at High Point (High Point sandstone), near Naples, N. Y. A mass of confused dermal plates, or shagreen, with prominent denticulations and possibly referable to Cladoselache has been obtained by Dr Clarke from the Marcellus shale of Leroy, N. Y., the original being preserved in the State Museum.

\section{Order ICHTHYOTOMI}

This order is represented in the Devonic only by detached teeth similar to those occurring in well known Pleuracanthid genera, and consisting of two or more sharp cusps attached to broad bases. No satisfactorily preserved remains, other than teeth, are known from an earlier period than the Lower Carbonic, and the most complete are of Permian age. It is customary to refer to this order most of the detached teeth known as Cladodus, although it is certain that teeth of the same form were common to several primitive genera - perhaps even to more than one family and order.

\section{Family PLFuracanthidaE}

Genus Diplodus

Under this name are comprised a number of Paleozoic species known only by the evidence of detached teeth, hence the status of the genus is

rU. S. Geol Sur. Bul. I6. I885. p. 72. 
more or less provisional. This fact being understood, it is convenient to retain the generic title pending such time as our knowledge of the entire organization remains sub judice, notwithstanding the prior employment of Diplodus amongst bony fishes (porgies, bass). S. A. Miller, in his work on North American Geology and Palacontology, has proposed its replacement amongst fossils by Dissodus; and $\mathrm{Dr}$ O. P. Hay prefers the earlier synonym of Dittodus.

\section{Diplodus priscus Eastman}

Plate I, figures 7, 8

I899 Diplodus priscus C. R. Eastman. Jour. Geol. 7:490, pl. 7, fig. I, 2 I899 Diplodus priscus S. Weller. Jour. Geol. 7:484

Teeth minute; the two principal cusps of dental crown divergent and slightly inclined backward, robust, conical, round in section, without lateral carinae; coronal surface marked with relatively few, prominent, slightly curved striae extending from the base nearly to the extremities on the anterior face, but shorter and usually fainter on the posterior face. Median denticle slender, sometimes much reduced, or in one specimen wanting altogether. Anterior border of root slightly produced downward; lower surface concave, elliptical in outline; posterior button developed.

This species, together with the one immediately to be described, is known by a number of examples of striated teeth from a peculiar deposit of the Upper Devonic in the vicinity of Elmhurst, Ill. As described by Dr Stuart Weller, who first noted the unconformable relations of the beds, the Devonic fossils are deeply buried in fissures of Niagaran limestone, appearances indicating that the joints were open, and became filled with sand and fossiliferous remains during the late Devonic. The sort of unconformity presented by this singular occurrence has also been observed and described by Clarke at Buffalo, N. Y. between the uppermost Siluric and Oriskany sandstone. It is designated by Dr Weller as "subterranean unconformity."

Formation and locality. Upper Devonic; Elmhurst, Ill. 
Diplodus striatus Eastman

Plate $x$, figures ro, Ir

I 899 Diplodus striatus $C$. R. Eastman. Jour. Geol. 7:49o, pl. 7, fig. 3, 4

I 899 Diplodus striatus S. Weller. Jour. Geol. $7: 484$

Of this species only a few fragmentary specimens were obtained by Dr Weller from the same locality as the last, the largest and most perfect being represented in plate $\mathrm{I}$, figure $\mathrm{s}$. It attains apparently about twice the size of the preceding form, and is distinguished from it by its finer striation, shallower root, and somewhat compressed section of its principal cones. The striae on the anterior face all curve uniformly in a spiral direction, but on the posterior face the tendency is to curve outward on either side of the median line to the lateral margin of the cones, where they terminate, exactly as in some species of Cladodus. None of the specimens show the full length of the median denticle, but it was apparently long and slender.

Formation and locality. Upper Devonic; Elmhurst, Ill.

Genus PHozbodus St John \& Worthen

Teeth differing from those of Diplodus in having three principal cones of about equal size, and from one to three very small intermediate cones.

Phoebodus politus Newberry

Plate I, figure I2 $^{2}$

1889 Phoebodus politus J. S. Nenterry. U. S. Geol. Sur. Monogr. r6:173, pl. 27 , fig. $27-28 \mathrm{a}$

I 899 Phoebodus politus C. R. Eastman. Jour. Geol. 7:49r, pl. 7, fig. 5

Newberry's original description of this rare and interesting form is as follows :

Teeth small, robust, breadth between tips of lateral cusps 6 to i $2 \mathrm{~mm}$, hight from 4 to $8 \mathrm{~mm}$, base broadly elliptical, thick, with a broad bilobed, padlike prominence in the middle portion of the upper surface, concave below, with a narrow arch between the cusps; cusps three, of nearly equal size, with minute rudimentary ones in the angles between them, all strongly recurved, flattened in front with salient, acute angles, rounded behind; surface smooth and polished, or bearing a few short, coarse striations. 
The relations of this species have been commonly supposed to be with Cladodus, rather than with Diplodus, but recent discoveries of more perfect examples which display the characters of the root, in this and other species, leave no doubt as to the Pleuracanthid nature of these teeth. An illustration is given in the accompanying plates of one of the most perfect specimens of P. polit us that has yet been obtained. The original is preserved in the Museum of Comparative Zoology at Cambridge, Mass.

Formation and locality. Cleveland shale (Upper Devonic); Ohio.

Family PLADODONTIDAE

An indefinable family, apparently closely related to the Pleuracanthidae.

Genus Cladodus Agassiz

This typically Carbonic genus occurs sparingly in the Neodevonic, but only two instances are known of its occurrence in the Mesodevonic, the species immediately to be described being found in the Columbus limestone of Ohio, and the next following from the Hamilton of Milwaukee, Wis. It is quite possible that some detached teeth of similar nature which range upward into the Carbonic belong in reality to Pleuracanthid sharks, their origin being traceable to forms like Protodus and Doliodus in the Lower Devonic. There are strong reasons for believing that the teeth of Lower Carbonic Cladodonts belonged to spineless sharks, and until recently it was supposed that the Devonic Cladoselache was also unarmed.

Cladodus prototypus sp. nov.

Plate $x$, figure I5

Founded upon a single robust tooth, the crown consisting of a stout erect median cone and five lateral denticles on either side, not much compressed, and all delicately striated. The outer pair of lateral denticles is much the largest, and nearly circular in cross-section. The median cone is elliptical in transverse section, slightly recurved, without sharp lateral edges, and very wide across the base. Its total hight, when complete, is estimated to have been about $3 \mathrm{~cm}$.

The general appearance of this tooth is suggestive of Cladodus 
striatus Agassiz, from the British Lower Carbonic limestone. ${ }^{x}$ The present example differs from the latter species, however, in the lesser compression of the crown, fewer lateral cones, and peculiar arrangement of the coronal striae. As many as 35 fine parallel nonbifurcating striae are visible on the external face of the principal cone, those of the middle portion running vertically, and those along the sides curving gradually outwards and terminating in a faint ridge along the lateral margin. The apexes of the median and nearly all of the lateral cones have unfortunately been broken away in the type specimen, and the root, also, is wanting. The width across the base line, in its present condition, is $3.6 \mathrm{~cm}$.

The unique specimen answering to the above description forms part of the collection purchased from the late Professor James Hall by the American Museum of Natural History in New York, and bears the museum catalogue number of 4257 . It is labeled as having been derived from the "Corniferous" (Columbus) limestone in the vicinity of Columbus, O., and the characteristic appearance of the matrix leaves no doubt as to the authenticity of the record. Its geological antiquity is greater than that of any other known species.

Formation and locality. Columbus limestone(Ulsterian); Columbus, O.

Cladodus monroei Eastman

Plate $\mathrm{x}$, figure 5

I900 $\mathrm{Cl}$ a dodus mon roei C. R. Eastman. Jour. Geol. 8: $3^{6}$, text fig. 2

The type of this species is a small, imperfectly preserved tooth found by $\mathrm{Mr}$ Charles E. Monroe in the Hamilton limestone of Milwaukee, Wis. The median cone is robust, very thick at the base, and indistinctly striated. The external denticles are also stout in proportion to the size of the principal cone, but the three intermediate denticles of either side are excessively small. The total hight of the median cone probably amounted to less than $1.5 \mathrm{~cm}$, and the width across the base $2.5 \mathrm{~cm}$.

Formation and locality. Hamilton limestone (Erian); Milwaukee, Wis.

I The teeth recently described under this name by E. B. Branson from the Salem limestone of Indiana are clearly distinct, and require a new specific name. 


\section{Cladodus coniger Hay}

I889 Cla dod us carin at us J. S. Nezebery. U. S. Geol. Sur. Monogr. I6: 103 I $899 \mathrm{Cl}$ a dod u s con iger $O$. P. Hay. Am. Nat. $33: 783$

In the meager description given of this species by Newberry, the teeth are stated to be "less than half an inch in breadth and hight, the base narrow, and bearing one central and four lateral cones, the exterior pair larger than the intermediate ones, but all much lower than the central denticle." The distinctive feature of the species is said to consist in four relatively strong carinations on the flattened posterior surface of the principal cone.

Teeth evidently belonging to this species are by no means uncommon in the Chemung of Warren county, Pennsylvania, but as a rule are imperfectly preserved. The general form is similar to that of C. concinnus Newberry, from the Cleveland shale of Ohio; and, as in that species, the pair of intermediate denticles is sometimes absent. The external cones also diverge outwards at a considerable angle. The principal cone is strongly compressed, more or less recurved, with sharp lateral edges, and prominently striated on both faces. The number of carinae along the flattened, moderately convex anterior face is not limited to two pairs, however, some specimens displaying twice that number. These are symmetrically arranged on either side of the median line, the two innermost being nearly vertical and rather more prominent than the rest.

Formation and locality. Chemung beds (Chautauquan); Warren, Pa. Cladodus sp. ind.

A single specimen of Cladodus, associated with other undetermined fish remains, is reported by Dr John M. Clarke from the Chemung fauna (High Point sandstone) at High Point, a mountain situated about 3 miles northwest of the village of Naples, N. Y. LU.S. Geol. Sur. Bul. I6. I885. p. 72]

\section{Order ACANTHODII}

Two families of Acanthodian fishes are known, one characterized by the presence of a single, the other by two dorsal fins, and both having 
representatives in the American Paleozoic. The Acanthodidae range from the Lower Devonic to the Lower Permian inclusive, the Diplacanthidae are confined to the Upper Siluric and Lower Devonic. The detached fin spines known as Machaeracanthus, Gyracanthus, and similar forms are regarded with much probability as belonging to fishes of this order.

Acanthodes ? pristis Clarke

I 885 A c ant hodes? prist is $J$. $M$. Clarke. U. S. Geol. Sur. Bul. I6. p. $4^{2}$ I89 I A c a thodes? pristis A. S. Woodzard. Cat. Foss. Fishes Brit. Mus. pt 2, p. 15

1902 A c anthoëssus? prist is O. P. Hay. U. S. Geol. Sur. Bul. r79, p. 273

Founded upon a considerable portion of the shagreen of an undoubted Acanthodian fish, the family position of which, owing to the nonpreservation of fins, is uncertanı. In the solitary specimen known, the greater number of scales have retained their natural, exceedingly compact arrangement, and are so minute as to indicate a species of very diminutive size. Their characters are given in the original description as follows. "The scales are very small, measuring $.5 \mathrm{~mm}$ on the edge, square or slightly subrhomboidal in outline, and one fourth as thick as wide. The adjacent edges at about two thirds the distance from the upper surface are strongly grooved by a single deep furrow. The upper surface of the scales is smooth and slightly convex."

The type specimen, which belongs to the United States National Museum, was obtained by Dr J. M. Clarke from the bituminous layers of the Portage beds (Rhinestreet shale) exposed in a Delaware and Lackawanna railroad cutting near the town of Sparta, N. Y. In Woodward's and Hay's catalogues, cited in the above list of references, the species is erroneously reported as from the Genesee shales of New York in which Palaeoniscid scales of the same character are known to occur.

Order SELACHII

To this order, which includes the sharks and skates, numerous Paleozoic teeth and fin spines have been ascribed, but only on account of their close resemblance to the corresponding hard parts of recent forms. So far 
as dependence can be placed upon analogy of this nature, forms allied to the modern Port Jackson shark (Cestracion or Heterodontus, text fig. 15) were present during the Devonic, and extremely abundant during the Lower Carbonic. Tamiobatis, known by a unique skull from the Devonic of Kentucky, is interesting in that, although probably a shark, its form was decidedly raylike. No true rays, however, appear earlier than the Mesozoic.

Entire skeletons of undoubted Selachii are known first from the Lower Lias. As for the detached dermal spines and tubercles occurring in various Paleozoic horizons, we are without means for determining their precise relations, hence they are conveniently grouped together under the head of "Ichthyodorulites." These are treated in the present contribution immediately after the Holocephali.

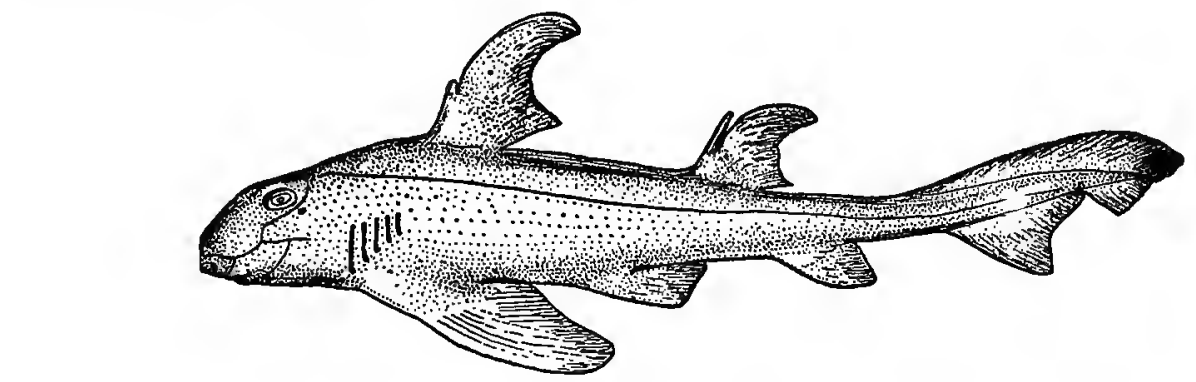

Fig. I5 Port Jackson shark, Cestracion philippi (female). Recent; Australia. x r-to (From Dean, after Garman)

Subclass HOLOCEPHALI

The following general remarks on the Holocephali and Chımaeroids, taken chiefly from Smith Woodward, may profitably find a place here:

Dental plates essentially similar to those of the existing Chimaerold fishes are met with in rocks as early as the Middle Devonic; but there is still no evidence of any member of the Holocephali which can not be included in the surviving order of Chimaeroidei. Some of the early forms were certainly armed with dermal plates; but paleontology as yet lends no support for the theory that the Chimaeridae are degenerate descendants of fishes once possessed of membrane bones. The earliest known complete skeletons are unfortunately only Liassic. 


\section{Order CHIMAEROIDEI}

In all known Chimaeroids, whether recent or extinct, the notochord is persistent and at most only partially constricted, the calcifications in the sheath, when present, consisting of slender rings more numerous than the neural and haemal arches. The pectoral fins are abbreviate, without segmented axis; and the pelvic fins in the male are produced into a pair of claspers. In the extinct forms there is no trace of any dermal plate developed in the opercular flap. The only clear evidence of evolution hitherto observed concerns the development of the peculiar dental plates. In each of the four known families the dentition consists of a few large plates of vascular dentine of which certain areas ("tritors") are specially hardened by the deposition of salts within and around groups of medullary canals, which arise at right angles to the functional surface. In most cases there is a single pair of such plates in the lower jaw, meeting at the symphysis, while two pairs (the so-called vomerine and palatine plates) are arranged to oppose these above. A permanent pulp remains under each plate, and growth thus takes place continually within as the oral surface is triturated by wear. In the surviving family of Chimaeridae these dental plates are much thickened, while the hinder upper pair ("palatines") are both closely apposed in the median line and considerably extended backwards.

The dental plates named Ptyctodus, from the Devonic of Russia, the Eifel district and North America, are essentially similar to those of modern Chimaeroids, but there are no representatives of the vomerine pair. The tritors, one only in each plate, are well differentiated, consisting of hard, punctate, superimposed laminae, arranged obliquely to the functional surface. The contemporaneous teeth known as Rhynchodus and Palaeomylus, however, exhibit more indefinite tritoral areas, or none. The symphysial facet is always distinct.

Spines which may be compared with those of Chimaeroids are also known from the Devonic and Carbonic systems, and Harpacanthus and Cyrtacanthus may perhaps be cited as examples of head spines. No 
Chimaeroid skeletons, however, have hitherto been satisfactorily determined from Paleozoic rocks, save for the possible exception of Menaspis. The problematical remains known as Dictyorhabdis priscus, from the Lower Siluric of Colorado, are very doubtfully of Chimaeroid nature. The most recent discussion of the relations between fossil and living Chimaeroids is that of Dr Bashford Dean, in the publications of the Carnegie Institute of Washington, I906. Some, changes in the classification are proposed by $\mathrm{Mr}$ C. Tate Regan in the Proceedings of the Zoological Society of London for the same year.

\section{Family PTYCTODONTIDAE}

A family at present indefinable, of doubtful ordinal position, known only by remains of the dentition and possible dermal ossifications. A single pair of large, laterally compressed dental plates present in each jaw, united at the symphysis, and either with trenchant oral margin, or developing one or more tritoral areas posteriorly. Rhynchodus undoubtedly represents the most primitive condition of dental plates, the tritors Ptyctodus and Palaeomylus arising subsequently, and indicating a more specialized stage.

Genus RHXNCHodus Newberry

Oral margin of dental plates simply trenchant, without tritoral areas. Upper and lower dental plates of similar form, except that in some species the symphysial margin is produced downwards into a spiniform process. Indications of cartilaginous unıon between each pair of dental plates are present on the inner symphysial facets.

\section{Rhynchodus secans Newberry}

I873 Rhynchodus secans $J$. S. Newberry. O. Geol. Sur. Rep't. v. I, pt 2, p. 3 IO, pl. 28, fig. I; pl. 29, fig. I, 2

I889 Rhynchodus secans J. S. Newberry. U. S. Geol. Sur. Monogr. I6:47, pl. 28 , fig. $1-3$

I $898 \mathrm{Rhynchodus} \mathrm{secans} \mathrm{C.R.} \mathrm{Eastman.} \mathrm{Am.} \mathrm{Nat.} 32: 485,546$

This species, which is the type of the genus, is not uncommon in the Columbus and Delaware limestones of Ohio and is interesting for having 
furnished a group of four teeth preserved in natural association. There is but little difference in the form of upper and lower dental plates, and both terminate anteriorly in prominent beaks. It is probable that the latter character is a generic one, it having been observed in several other species as well, but never in Ptyctodus. An excavation is noticed just back of the beak in the upper dental plate where the terminal point of the lower came in contact with it, thus proving that the relations between the two pairs were the same as in Ptyctodus. The lower dental plate is deeper than the upper, and marks of wear are frequently observed along the inner side of the functicnal margin.

\section{Rhynchodus excavatus Newberry}

I 877 Rhynchodus excavatus T.S. Newberry. Geol. Wis. 2:397

I 878 Rhynchodus excavatus J. S. Newberry. N. Y. Acad. Sci. Ann. r: r 92 1878 Rhynchodus occidentalis $J$. S. Nezwberry. N. Y. Acad. Sci. Ann. I : 192

I889 Rhynchodus excavatus $J$. S. Newberry. U. S. Geol. Sur. Monogr. I6: 50, pl. 29 , fig. I

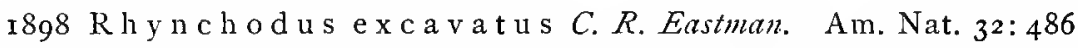

i $898 \mathrm{Rhynchodus}$ occidentalis $C$. R. Eastman. Am. Nat. 32:485

A comparison of the type specimen of the so called $R$. occidentalis, which remains as yet unfigured, with an extensive series of dental plates belonging to the earlier described R. excavatus, leads to the conclusion that the two forms are identical. Indeed, it is certain that Newberry would himself have recognized their identity, had he been acquainted with more perfect specimens, such as are now accessible. Any one may satisfy himself on this point who will take the trouble to verify the original description of $\mathrm{R}$. occidentalis, which reads as follows:

Teeth of small size, much compressed. Anterior margin slightly curved, but nearly vertical. Superior margin gently arched downward from the prominent anterior point, forming a much compressed triturating surface or edge. Posterior portion of upper margin acute edged. Exterior lateral surface striated obliquely backward. Basal margin formed by the edges of external and internal laminae, of which the edges are broken and irregular. From the Hamilton limestone, Waverly, Ia. 
Little need be added by way of supplementing the above description. The total length of the dental plates rarely exceeds $5 \mathrm{~cm}$, and there is close similarity between those of the upper and lower jaws, excepting that the symphysial margin of the lower is produced into a long and slender descending spine, and the cutting edge of the upper is somewhat less arched or "excavated" than in the lower dental plates. As shown by marks of wear, the tips of the lower dental plates closed outside and slightly behind those of the upper, in the same manner as in Ptyctodus. Dental plates differing but little from those of the present species have been described from the Eifel Devonic, the complete dentition being known in the so called "Ram-

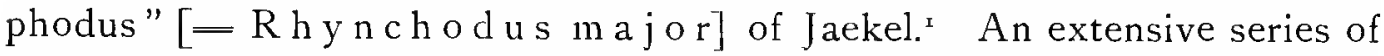
specimens, collected many years ago by Mr Orestes St John from the Cedar Valley limestone of Iowa, is now preserved in the Museum of Comparative Zoology at Cambridge.

Formation and locality. Hamilton limestone; Milwaukee, Wis., and Cedar Valley limestone of Iowa.

Rhynchodus pertenuis Eastman

Plate 2, figure 5

I904 Rhynchodus pertenuis C. R. Eastman. Am. Nat. 38: 297, text fig. 2

Dental plate narrow and elongate, with sharp and extended functional margin and knife blade cross-section; anterior beak prominent, no symphysial spiniform process, external surface smooth.

The unique dental plate upon which this species is founded was obtained from the Chemung of Franklin, in Delaware county, New York, and is now preserved in the State Museum at Albany. The general outline and proportions of this plate differ from those of all other species, and the absence of a spiniform symphysial process is a very unusual feature. But for the trenchant functional margin and narrow cross-section, the specimen might readily be mistaken for a lower dental plate of Ptyctodus, instead of Rhynchodus. That it is properly a mandibular element, and

'Jaekel, O. Ueber Ramphodus, etc. Sitzungsber Ges. naturf. Freunde, Berlin, I903. p. 383-93. Cf. also Am. Nat. 1904. 38: 296 ; Centralblatt für Mineral. 1900. p. I77. 
referable to the latter genus, seems to admit of no question. The hollow along the base indicates the extent to which the plate was inserted in the supporting cartilage of the jaw. The total length is $9 \mathrm{~cm}$.

Formation and locality. Chemung beds; Franklin, N. Y.

Rhynchodus sp. ind.

Dental plates of an undetermined species of Rhynchodus are reported by Dr J. M. Clarke ${ }^{-}$as occurring in the High Point (Chemung) fauna near Naples, N. Y.

Genus ptrcropus Pander

Oral surface triturating, the single tritoral area of each dental plate well differentiated, and consisting of hard, punctate, superimposed laminae arranged more or less obliquely to the functional surface. Lower dental plates with symphysial beak, which, as shown by marks of wear, closed against the outer margin of the upper dental plates.

Ptyctodus punctatus sp. nov.

This species is readily distinguished from all others previously described by the comparative coarseness and peculiar arrangement of the medullary canals passing through the tritoral area. The sides and functional surface of the latter are completely covered by a network of small polygonal pittings, formed by the termini of the medullary canals. As these are not grouped in parallel lines, there is no surface indication of laminar structure.

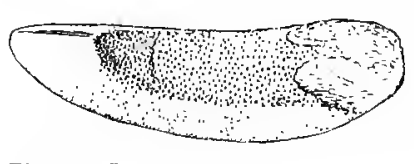

Fig. 15a Ptyctodus, unctatus. Nat. size
The simpler arrangement of the medullary canals in this species, taken in connection with its greater antiquity as compared with other known species, suggests that it is a primitive character.

Formation and locality. The single detached tritor upon which the above description is founded was obtained from the Onondaga limestone (Ulsterian) of Leroy, N.Y. The type specimen is preserved in the Museum of Comparative Zoology at Cambridge, Mass. and another example, from the corresponding rocks of Ohio, is in the collections of the American Museum of Natural History.

I U. S. Geol. Sur. Bul. I6. I885. p. 72. 
Ptyctodus calceolus Newberry \& Worthen

I866 Rinodus calce olus Nezelerry So Worthen. Pal. Ill. 2: Io6, pl. Io, fig. Io I870 Ptyctodus calceolus Nezoberry So Worthen. Geol. Sur. Ill. Rep't, 4:374 I875 Ptyctodus calceolus $J$. S. Nezoberry. O. Geol. Sur. Rep't. v. 2, pt 2, p. 59, pl. 59, fig. I 3

I $898 \mathrm{Pty}$ ctodus calceolus C. R. Eastman. Ia. Geol. Sur. Rep't. 7: ir5, text fig. Ioa

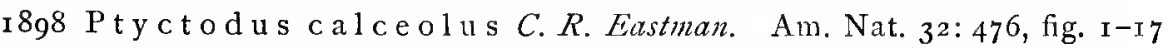

I899 Ptyctodus calceolus S. Weller. Jour. Geol. $7: 484$

Dental plates compressed into a thin cutting edge shortly behind the symphysis, but widening gradually, becoming more or less outwardly curved, and the oral surface occupied for nearly its entire width by the tritoral area, the inner margin of which is more strongly curved than the other. Laminar structure of the tritors indicated superficially by fine punctae arranged in parallel rows running obliquely across the functional surface. The compressed edge in advance of the tritor in the lower dental plate slopes rapidly upward and terminates in a strong anterior beak. Upper dental plates similar to the lower, except that the symphysial border is rounded and not produced into a beak.

In spite of the extraordinary abundance of this species in various Middle and Upper Devonic localities, as indicated by detached tritors, complete dental plates are very rare, their structure being on the whole very fragile. Of widespread distribution in the Hamilton, the species is most prolific in the Upper Devonic State Quarry beds near Iowa City, a single exposure only a few yards square having yielded thousands of abraded tritors. No specimens have been hitherto reported from New York State, nor has the genus itself been known to occur in rocks of earlier age than the Hamilton in this country. Recently, however, the writer has had the opportunity of examining a nearly perfect lower dental plate, evidently of this species, which was collected by Mr Edgar E. Teller from the Genesee shale at Eighteen Mile creek, near Buffalo. The precise level at which this dental plate was found is from near the base of the Conodont bed, the exposure 
being referred to as "section $\mathrm{H}$ " and photographed in plate 4 of Grabau's Geology and Palaeontology of Eighteen-Mile Creek. The specimen in question is excellently preserved, measures $3 \mathrm{~cm}$. in length, and lacks only the extreme tip of the symphysial beak. A single large dental plate, apparently referable to this species, has also been obtained by $\mathrm{Dr}$ John M. Clarke from the Goniatite or Parrish limestone (Portage) near Naples, N. Y.

Formation and locality. Middle Devonic of Iowa, Illinois, Missouri, Wisconsin and Manitoba. Upper Devonic of Iowa and Elmhurst, Ill. Genesee shale of Eighteen Mile creek, and Portage of Naples, N. Y.

\section{Ptyctodus compressus Eastman}

ז898 Pt yctodus compressus C. R. Eastman. Am. Nat. 32: 479, fig. 18-27

The tritors in this species are relatively longer and narrower than in the preceding, and the oral margin in advance of the triturating surface is developed into a long, sharp cutting edge. In all other species this trenchant margin is shorter than the tritoral area, but in the present form it is invariably longer, sometimes exceeding the length of the tritor by one iourth. The dental plates are as a rule less curved than those of $P$. calc e olus, and the symphysial beak less produced.

Formation and locality. State Quarry beds (Upper Devonic); North Liberty, Johnson county, Ia.

\section{Ptyctodus ferox Eastman}

I $898 \mathrm{Ptyct}$ d dus ferox $C$. R. Eastman. Am. Nat. 32: 48o, fig. 35-40

I899 P tyctodus ferox C. R. Eastman. Jour. Geol. 7: 282

Dental plates unusually large and massive, attaining a total length of about $14 \mathrm{~cm}$, and exhibiting but slight lateral curvature. Lower dental plate with a stout symphysial beak, the front margin projecting downward into a long spiniform process, evidently for strengthening the symphysial union. Anterior margin of upper dental plate uniformly rounded, not produced into a beak or spiniform process, and showing on the outer face

I Buffalo Soc. Nat. Sci. Bul. I 898. 6: 5 . 
marks of contact with the opposing dentition. Inner surface of both upper and lower dental plates with a roughened triangular symphysial facet.

The fact that the smaller and younger plates belonging to this species have a decidedly Rhynchoduslike aspect indicates that the functional margin in immature teeth was simply trenchant, the tritors not being developed until a comparatively late period. Rhynchodus, therefore, represents a more primitive stage than either Ptyctodus or Palaeomylus in the development of dental plates, its relations to contemporary types being closely paralleled by Rhinochimaera amongst recent genera. ${ }^{x}$ There is considerable reason for believing that Ptyctodonts were provided with dermal ossifications, and in particular it is difficult to avoid the suspicion that the fin spines known as Heteracanthus or "Gamphacanthus" were borne by members of this family, possibly by the very species under discussion. The dental plates of P. f e rox are accompanied not only by dermal spines, but by tuberculated dermal plates not unlike those associated with Myriacanthus. One of these is illustrated in plate I, figure 6, of the present memoir. As yet, however, no specimens have been found which demonstrate the supposed specific identity of these various bodies.

Formation and locality. Hamilton limestone (Erian); Milwaukee, Wis. Cedar Valley limestone (Mesodevonic) of Iowa and Illinois. State Quarry beds (Neodevonic); Johnson county, Iowa.

\section{ICHTHYODORULITES}

Genus onchus Agassiz

Spines of small size, laterally compressed; sides of exserted portion ornamented with smooth or faintly crenulated longitudinal ridges; no posterior denticles. Represented in this country by two Upper Siluric (O. clintoni and O. pennsylvanicus) and one Devonic species. An undescribed form is also known from the Niagaran of Cumberland, Md.

I Garman, S. Chimaeroids, especially Rhinochimaera and its Allies. Museum Comp. Zool. Bul. 1904, 41: 246. Dean, B. Chimaeroid Fishes and their Development. Carnegie Inst. Wash. 1906, Pub. 32, p. I 26. 


\section{Onchus rectus Eastman}

Text figure 16

I899 Onchus rectus C. R. Eastman. N. Y. State Geol. izth An. Rep't, p. $3^{23}$, fig. 4

Spines attaining a total length of about $5 \mathrm{~cm}$, nearly rectilinear, and gradually tapering to an acute point. Inserted portion round in cross-section, very delicately striated; exserted portion laterally compressed, without trace of posterior denticles, the sides traversed by about Io fine longitudinal ridges. The latter are nonbifurcating, regularly spaced, and of uniform size with the exception of the one along the anterior margin; this is twice the width of the others, and is of triangular cross-section.

Formation and locality. Chemung group; Ontario and Western Railroad tunnel between Merrickville and North Walton, Delaware co., N. Y.

\section{Genus homacanthus Agassiz}

This genus, which is evidently closely allied to Ctenacanthus, is thus defined by Smith Woodward: "Dorsal fin spines of small size, slender, more or less arched, laterally compressed, and gradually tapering distally; sides of exserted portion ornamented with few, large, smooth, widely spaced longitudinal ridges; a similar ridge also forming a large anterior keel; posterior face with a double series of large, downwardly curved denticles." American

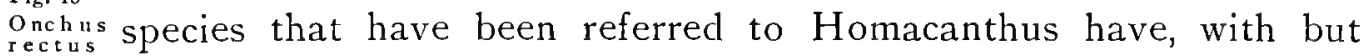
Dorsalfin two exceptions, since been removed to other genera, but at least spine.

one Devonic representative of this genus seems to be indicated by the spines described in the following paragraph. 


\section{Homacanthus acinaciformis Eastman}

Plate I, figire 16

r9o3 Hom a canthus acinaciformis C. R. Eastman. Mus. Comp. Zool. Bul. 39: 2 I 8 , pl. 5 , fig. $5^{8}$

Spines comparatively small, slender, gradually tapering, gently and uniformly arched; lateral surface with five or six continuous longitudinal ridges; posterior denticles slender, rather widely spaced.

The small spines known under this designation are more strongly curved than those found in the Lower Carbonic limestone, but according to $\mathrm{J}$. W. Davis, there is considerable variation in this respect, even amongst spines belonging to a single species. Some resemblance is to be noticed between the present form and the Upper Devonic spines from Ohio described as $\mathrm{H}$ oplonchus parvulus by Newberry.

Formation and locality. Chemung group; Warren, $\mathrm{Pa}$.

Genus Ctenacanthus Agassiz

Dorsal fin spines robust, often attaining a large size, laterally compressed; sides of exserted portion ornamented with longitudinal ridges, usually crenulated or denticulated, rarely smooth; posterior face flat or concave, with a series of small denticles upon each margin.

It is certain that spines of this character were possessed by sharks of more than one genus. Reference has already been made to the occurrence of these defenses in Cladoselache, and Newberry was strongly inclined to suspect, from a discovery in the Waverly of Ohio, ${ }^{x}$ that Ctenacanthus and Orodus may be synonymous. Of primary importance in the distinction of species is the general conformation of the spines, especially their curvature, form of cross-section, and length of inserted portion. Next in order are to be considered the number, shape and direction of the longitudinal costae, with the special ornamentation of the same; and still further distinctive characters are to be found in the nature of the posterior face and anterior margin, or "cutwater." A class of spines agreeing in their abbreviate, 
stumpy proportions, and inserted very obliquely in the integument, is probably to be correlated with the posterior dorsal fin. They contrast strongly with the group of slender, elongated and tapering spines which were undoubtedly situated in advance of the first dorsal fin. ${ }^{x}$

\section{Ctenacanthus wrighti Newberry}

I884 Ctenacanthus wrighti $J$. S. Nezebery'. N. Y. State Mus. 35th Rep't. p. 206 , pl. I6, fig. I $2-1+$

I889 C't enacant hus wrighti J. S. Newberry. U. S. Geol. Sur. Monogr. I6:66, pl. 26 , fig. 4

An examination of the peculiarly shaped and unusually large fin spine upon which this species is founded, now preserved in the American Museum of Natural History in New York, has served to confirm the correctness at all points of Newberry's description, which is as follows :

Spine of large size, long triangular in outline; anterior margin straight, laterally compressed; medullary cavity large, open posteriorly to the middle of the spine; posterior face traversed above by a strong rounded ridge; [posterior] denticles small; surface of exposed portion entirely covered with pectinated ridges of nearly uniform width on the front and sides, becoming narrower and less distinctly pectinated near the posterior margin.

The spines of this species are very striking in their characters as regards both form and markings. The anterior margin seems to have been absolutely straight from base to summit. Along the line of junction between the enameled and buried portions the spine must have been 2 inches wide, but it tapered rapidly upward, terminating in a slender, acute point. The exposed surface is more completely covered with ridges similar in character, and the pectination is more crowded than in any other species known to me. In its broad base and its general and uniform ornamentation this spine has some resemblance to $\mathrm{C}$. s peciosus St J. \& W., specimens of which have been in my hands, but the line of demarcation between the ornamented and buried portions is less oblique, showing that the spine was more erect [and hence referable to the anterior dorsal fin]; the ridges are considerably coarser and the form is straighter. The pectination is also less oblique and closer, compared with the coarseness of the ridges.

Formation and locality. Hamilton limestone (Erian), "near the middle of the Moscow shale; Cashong creek, Yates county, N. Y."

r Science. n. S. I90I. I4:795. 


\section{Ctenacanthus randalli Newberry}

r889 Ctenacanthus randalli $J$. S. Newberry. U. S. Geol. Sur. Monogr. I6: 105

This species, which has never been illustrated, is founded upon the proximal portion of an extremely large spine, estimated to have been at least $30 \mathrm{~cm}$ in length. The original description is as follows :

Dorsal fin spines 12 inches or more in length by $\mathrm{I} / 2$ inches in width at base of ornamented portion; form slightly curved backward, sides compressed, basal portion conical, smooth, or finely striated longitudinally; line of demarcation between ornamented surface and base strongly marked, inclined downward and forward at an angle of $30^{\circ}$ with the axis of the spine; ornamented surface near base formed by about 40 fine, parallel, subequal, closely crowded ridges on each side of the median line, and these bear small, rounded, closely approximated tubercles.

Formation and locality. Olean conglomerate (Chemung group); near Warren, Pa.

\section{Ctenacanthus chemungensis Claypole \\ Plate 7 , figure 3}

I $885 \mathrm{Ct}$ enacanthus chemungensis $E$. $W$. Claypole. Am. Ass'n Adv. Sci. $33^{d}$ meeting, Phila. Proc. 1884. p. 490 (name only)

This name was applied by Professor Claypole without definition or illustration to small fin spines obtained by him from the Chemung of Bradford county, Pennsylvania, whose length was stated to be "less than half that of Ct. vetustus."

To this species may probably be referred a number of small, gently arcuate, finely ornamented spines which were collected by the late Professor Charles E. Beecher and others from the Chemung of Warren county, Pennsylvania, examples of which are preserved in the New Haven and Cambridge Museums. Spines of similar nature have also been obtained from two or three localities in New York. One in the State Museum at Albany bearing the locality label ${ }_{1} 783$ is from the Chemung between Friendship and Nile, N. Y., and displays the delicate ornamentation very clearly. Another, belonging to the Museum of Comparative Zoology at Cambridge, is from the same horizon along the bank of Fall creek, near Ithaca, N. Y., and was collected many years ago by Dr Richard Rathbun. 
None of these spines appear to have exceeded $10 \mathrm{~cm}$ in length, and they are frequently much shorter, their form being narrow and gradually tapering. The flattened sides are covered with numerous threadlike costae, as many as twenty being observed toward the base, and these are for the most part continuous; when new longitudinal ridges are formed, they arise by implantation. The costae are finely pectinated at intervals varying from twice to three times their own width, thus giving rise to a finely punctate appearance when seen in impression, as is usually the case.

Formation and locality. Chemung group; New York and Pennsylvania.

Genus acantholepis Newberry

Spines of large size, very much laterally compressed, thin walled, internally hollow, in form gently arcuate, wide at the base, and gradually tapering to an acute point. Sides of exserted portion nearly flat, ornamented with numerous fine stellate tubercles; these are either irregularly arranged, or in some cases exhibit a tendency toward concentric arrangement along lines of growth. Tubercles along either side of the posterior margin enlarged so as to form a double row of denticles directed at right angles to the margin. Appearances of at least one specimen suggest that the basal portion is segmented.

The spines which are provisionally included under this title ${ }^{x}$ were first confused with Oracanthus by Newberry, but subsequently interpreted by him as dermal plates or scutes of "Placoderms," and supposed to be of similar nature to those which have received the name of Acanthaspis. Still later, their resemblance to the triangular ichthyodorulites of Psammosteus was pointed out by Smith Woodward. The conclusion reached by the present writer is that they are dermal defenses of Chimaeroids, probably dorsal fin spines. Their extremely thin walls, as seen under low magnifying power in worn specimens, exhibit the structure of vasodentine, and are traversed by coarse, branching longitudinal canals. In external characters

${ }^{\mathrm{I}}$ For this designation, preoccupied amongst insects, S. A. Miller has proposed the not altogether pleasing sobriquet of "Eczematolepis," an example of "index-learning that turns no student pale." 
they bear considerable resemblance to the spines described as Phlyctaena. canthus and Apateacanthus. Considering the uncertain status of these and similar "genera" founded upon isolated fraginents, it hardly appears advisable to change their provisional designations in those cases where they happen to be preoccupied.

\section{Acantholepis fragilis Newberry}

Plate 3, figure 3

I857 Oracanthus fragilis, O. granulatus, and O. abbreviatus $J$. $S$. Nezwberry. Nat. Inst. Proc. n. s. x: 126

I875 Acantholepis pustulosus J. S. Newberry. O. Geol. Sur. Rep't, v. 2, pt 2 , p. 38 , pl. 56 , fig. $x-6$

I889 A cantholepis pustulosus J. S. Nezwberry. U. S. Geol. Sur. Mónogr. 16: 34, pl. 31, fig. 5

1889 Eczematolepis pustulosus S. A. Miller. North Am. Geol. \& Pal. p. 586 , text fig. 1098

r8gi Acantholepis pustulosus A. S. Woodward. Cat. Foss. Fishes Brit. Mus: pt 2, p. 129

Detached spines sometimes attaining a length of $25 \mathrm{~cm}$ and exhibiting the characters of the genus. Inserted portion not observed, but some specimens show indications of having been expanded laterally at the base, as well as produced in an anteroposterior direction. Evidence is lacking that the spines occurred in pairs, or were serially arranged.

According to Professor Newberry, the exserted portion of the spine is peculiar in being composed of two pieces which are united by an oblique suture, certainly a most unusual condition amongst ichthyodorulites. Only one of Newberry's originals, however, is known to have shown this feature, and as none have been observed elsewhere, it is perhaps open to doubt whether the exceptional spine was entirely normal in this respect. The confirmation of other specimens would certainly be desirable before admitting the segmented character of the base.

Fragmentary spines apparently referable to this species have been collected by $\mathrm{Mr} \mathrm{F}$. K. Mixer and $\mathrm{Dr} \mathrm{H}$. U. Williams from the Onondaga limestone near Buffalo, and numerous examples have been obtained from 
strata of the same horizon at Leroy, N. Y. One fairly well preserved spine belonging to the New York State Museum is labeled as having been derived from a "ravine $2 \mathrm{r} / 2$ miles south of Truxton Corners, East branch," the horizon being probably the same as the foregoing. Its characters are somewhat indistinctly shown in plate 3, figure I. Typically the species occurs in the Columbus and Delaware limestones of Ohio, but is apparently also represented in the Hamilton of Milwaukee, Wis.

Horizon. Ulsterian; New York and Ohio. Erian; Wisconsin.

\section{Genus PhLYctannacanthus Eastman}

Arcuate spines of large size, with flat lateral surfaces, very broad at the base, and gradually tapering to an acute point. Ornamentation and other characters as in Acantholepis, except that the exserted portion is certainly unsegmented. Inserted portion triangularly expanded, thin walled and hollow, recalling the conditions in the corresponding portion of Stethacanthus.

\section{Phlyctaenacanthus telleri Eastman}

I 898 Phlyctaenacanthus telleri C. R. Eastman. Am. Nat. 32:55r, text fig. 49

1899 Phlyctaenacanthus telleri C. R. Eastman. Jour. Geol. 7:283

The spines assigned to this species are scarcely distinguishable from those of Acantholepis, their form, structure and ornamentation being practically identical. The exserted portion, however, has been definitely ascertained to consist of but a single piece, and the inserted portion (unknown in Acantholepis) appears to have been embedded in the soft parts in similar fashion as in Stethacanthus. Admitting these remains to be fin spines, it would certainly seem that a like interpretation should be applied to Acantholepis.

\section{Genus apateacanthus Woodward}

Fin spines elongated, slender, gradually tapering, extremely compressed laterally; sides ornamented with irregular series of fine tuberculations; posterior border with one (or two ?) close series of acute, hookshaped, downwardly pointed denticles. The genus is apparently closely related to the preceding. 


\section{Apateacanthus vetustus (Clarke)}

Plate 3, figure 5

I885 Pristacanthus vetustus $J$. M. Clarke. U. S. Geol. Sur. Bul. I6, p. 42, pl. I, fig. 7

1889 Pristacanthus vetustus $J$. S. Newberry. U. S. Geol. Sur. Monogr. 16: $6 \mathrm{I}$

I89I A pate a canthus vetustus $A$. S. Woodward. Cat. Foss. Fishes Brit. Mus. pt 2, p. II

Known 'only by the type specimen, which is extremely imperfect, but presents characters suggestive of Chimaeroid affinities. Spine composed of an extremely thin layer of vasodentine, probably hollow internally, lateral surface nearly flat, of uncertain width, without costae, and covered with sparsely scattered stellate tubercles of extremely minute, almost microscopic size. Posterior border set with closely spaced hook-shaped denticles of relatively large size, their apexes directed downwards.

It is unfortunate that the specimen which affords the only information we possess of this genus and species should have been considerably injured in fossilization, both extremities being broken away, and also a part of the sides, including the whole of the anterior margin. The width, therefore, of the lateral surface, as well as the total length of the spine, is indeterminate. However, the preserved portion indicates a spine of large size, gradually tapering, and perhaps slightly arcuate in form. In two respects the spine may be said to be quite remarkable; first, for the large size and close approximation of the posterior denticles, 14 of which remain intact; and secondly, for the rudimentary nature of the ornamentation. The tubercles, still faintly stellate, are almost imperceptible to the unaided vision, and are without regular arrangement. The flat sides, tuberculated ornament, and absence of longitudinal costae are characters which suggest affinity with the two preceding genera, hence the form may be looked upon as a late survival of Mesodevonic Chimaeroids. The type specimen is preserved in the United States National Museum.

Formation and locality. Upper portion of the Cashaqua shale (Portage); near Milo, Yates county, N. Y. 


\section{Genus heteracasthus Newberry}

Gamphacanthus Miller

Spines of moderate size, broad and laterally compressed at the base, but soon becoming subtriangular in section, nearly rectilinear, and gradually tapering toward the acute apex. Internal cavity relatively large, extending nearly to the apex, and open on the posterior margin for a considerable distance. No anterior keel; posterior denticles not observed. Exserted portion ornamented with finely crenulated longitudinal ridges which become smooth and flat with wear, and are separated by fine, denticulate, intercostal grooves.

\section{Heteracanthus politus Newberry}

r889 Heteracanthus politus $J$. S. Netubery. U. S. Geol. Sur. Monogr. 16:66, pl. 21, fig. 4, 5

1892 Gamphacanthus politus $S$. A. Miller. North Am. Geol. \& Pal. p. 7 I5

r 898 Heteracanthus politus C. R. Eastman. Am. Nat. 32:552

I899 Heteracanthus politus C. R. Eastman. Jour. Geol. 7:282

Spines attaining a total length of abont $20 \mathrm{~cm}$, very broad at the base, and with Ctenacanthuslike ornamentation. The longitudinal ridges, which are rather numerous and closely apposed, become perfectly smooth when worn, their presence being indicated only by the fine and deep intercostal grooves - the so called "sinuous or denticulate longitudinal sutures" of Newberry. More or less variation in size and number of the costae is to be observed amongst different examples. The basal portion seems to be regularly expanded, without forming an asymmetrical "shoulder" as in Physonemus, Stethacanthus etc.

Bilaterally symmetrical as these spines undoubtedly are, their position must have been in the median line of the body, and not, as suggested by Newberry and others, along the anterior margin of the pectoral fins. That they belonged to Chimaeroids seems very probable, and they are an invariable accompaniment of the large dental plates described as Ptyctodus ferox in the western Devonic. A characteristic Mesodevonic species, it is interesting to note its presence in the fauna of the Portage shale, as 
indicated by one rather large spine preserved in the State Museum at Albany, from western New York.

Formation and locality. Hamilton limestone (Erian); Milwaukee, Wis. Cedar Valley limestone and State Quarry beds; Iowa. Portage shale (Senecan); New York.

\section{Heteracanthus uddeni Lindahl}

I 897 Heteracanthus uddeni $J$. S. Lindahl. Cinn. Soc. Nat. Hist. Jour. I 9: 95 , pl. 6

i 898 Heterac anth us uddeni $C$. R. Eastmian. Am. Nat. 32:557

I 899 Heteracanthus ud deni $C$. R. Eastman. Jour. Geol. 7:282

Spines of moderate size having the distal portion essentially as in the preceding species, but the basal portion curving forward so as to form a rounded anterior projection or "shoulder," somewhat similar to that in Stethacanthus. The longitudinal costae are finer and more closely crowded than in the type species, and exhibit a sigmoidal curvature toward the base.

Formation and locality. Cedar Valley limestone (Mesodevonic); Buffalo, Waterloo and Waverly, Ia. Hamilton limestone (Erian); Milwaukee, Wis.

Genus Machatracanthus Newberry

Syn. Machaerius Roualt; Dinacanthodes Fritsch

Spines, so far as known, elongated, tapering, more or less curved, and somewhat laterally compressed, with sharp edges and a very large longitudinal ridge on each side; central cavity extending nearly to the apex; external surface covered with a thin layer of ganodentine, smooth, finely punctate, or longitudinally striated.

The resemblance between the spines referred to this genus and those occurring in advance of the pectoral fins in Acanthodes, together with the fact that the proximal portion indicates a corresponding position, has been interpreted as pointing to Acanthodian affinities. 


\section{Machaeracanthus peracutus Newberry}

r857 M a chaeracanthus peracutus $J$. $S$. Neqeberry. Nat. Inst. Bul. p. I25 r862 Machaeracanthus peracutus $J$. S. Newberry. Am. Jour. Sci. [2] 34: 74 , text fig. 2

r873 Machaeracanthus peracutus $J$. S. Newberry. O. Geol. Sur. Rep't, v. I, pt 2, p. $3 \circ 5$, pl. 29 , fig. 6

r889 $\mathrm{M} \mathrm{a} \mathrm{c} \mathrm{hae} \mathrm{racanth} \mathrm{us} \mathrm{peracut} \mathrm{us} \mathrm{J.S.} \mathrm{Newberry.} \mathrm{U.S.} \mathrm{Geol.} \mathrm{Sur.} \mathrm{Monogr.}$ r6: 40, pl. 29, fig. 6 and woodcut

Spines of moderate or large size, slightly curved, gradually tapering, and traversed along the middle by a prominent ridge, which is distinctly triangular in cross-section on one side of the spine throughout its entire length, and more or less rounded on the other. Lateral edges sharp, apex acute, external surface smooth or with extremely delicate striae which are convergent inward at a slight angle with the external margins.

Formation and locality. This species, which is the type of the genus, has been previously supposed to be confined to the "Corniferous" (Columbus and Delaware) limestone of Ohio. A few examples, however, have been obtained within recent years from the Onondaga limestone of Leroy and Lime Rock, in New York State.

Machaeracanthus sulcatus Newberry Plate 3 , figure 6

r 843 "I chthyodorulite" $J$. Hall. Nat. Hist. N. Y. pt 4, p. r74, woodcut fig. 69

r 857 Machaeracanthus sulcatus J. S. Newberry. Nat. Inst. Bul. p. 6

r870 Machairacanthus sulcatus E. R. Lankester. Geol. Mag. 7:398, woodcut fig. 3

r873 Machaeracanthus sulcatus $J$. S. Newberry. O. Geol. Sur. Rep't, v. r, pt 2, p. 305

r886 Machaeracanthus sulcatus T. H. Lennox. Can. Inst. Proc. 3: r 20

I889 Machaeracanthus sulcatus $J$. S. Newberry. U. S. Geol. Sur. Monogr. 16: 40, pl. 29, fig. 5

Spines of about the same size as the type, and differing from it principally in that the less strongly carinated face bears several prominent longi- 
tudinal sulci, separated by narrow ridges, which terminate before reaching the distal three fourths of the spine.

Regarding the distribution of this species, Newberry offers the following remarks :

It would seem that the sharks that carried these spines were more numerous in those portions of the Corniferous sea which covered western New York and southern Canada than in the more open waters of the area now occupied by Ohio. In the exposures of the Corniferous limestone on Kelly's island, Lake Erie, at Sandusky, Delaware and Columbus, O., fragments or complete spines of $\mathrm{Machaeracanthus} \mathrm{major}$ and M. perac ut us are not at all uncommon, but though collecting extensively myself in those localities I never obtained there a specimen of M. sulcat us.

Formation and locality. Onondaga limestone (Ulsterian); various places in New York State and Canada, and in the corresponding horizon at Milford, $\mathrm{O}$.

Machaeracanthus longaevus sp. nov.

Plate 2, figure 8

Spines attaining considerably larger dimensions than the type and differing principally in their greater width and conformation of the median carina. The latter is sharply triangular on one side in the distal portion only of the spine, gradually becoming widened and flattened until in the proximal portion it is nearly rectangular in cross-section. No longitudinal sulci.

This species, the only one known to persist as late as the Hamilton, is founded upon an interesting specimen belonging to the Buffalo Society of Natural Sciences, and derived from the so called "Trilobite bed" on the shore of Lake Erie near Eighteen Mile creek, New York. It was kindly placed in the hands of the writer for description by its discoverer, Mr F. K. Mixer, of Buffalo. Portions of two spines are preserved in counterpart on the same slab, embedded in which are pygidia of Phacops rana, and tests of Spirifer mucronatus and Ambocoelia umbonata, characteristic fossils of the Hamilton beds.

The present example is interesting in that it is one of the few in which spines of both pectoral fins are preserved in natural association. That this 
is the case, instead of there being merely a single, large broken spine, is evident from the similar proportions and general appearance of the two spines, one of which clearly represents the proximal and middle portions, and the other a section extending from about the middle for a considerable distance beyond in the direction of the apex. The form of the cross-section leaves no doubt that both spines present the same aspect, presumably the outer or external face. On the opposite, or internal face, the median carina appears to be gently rounded throughout its entire length. One of the distinguishing characteristics of this species, however, is that the axial ridge on the side which is presumed to be external remains sharply triangular only in the distal half of the spine, becoming widened into a broad flat elevation, smooth or but faintly striated, and nearly rectangular in crosssection, toward the base of the spine. The general surface is smooth, save for the usual delicate striae, slightly convergent toward the apex, and possibly of the same nature as growth lines. The absence of deep longitudinal grooves distinguishes this species from M. sulcatus and M. bohemi$\mathrm{cus}$, the latter having been originally referred to Ctenacanthus. A few doubtful fragments, suggestive either of this species or the preceding, have been obtained from the Hamilton of Milwaukee, Wis.

Formation and locality. Hamilton limestone (Erian); Eighteen Mile creek, N. Y. (and Wisconsin ?).

\section{Genus greacasthus Agassiz}

The paired fin spines of this genus, ${ }^{1}$ which are not known to be associated with other types of dermal defenses in the rocks of this country, are thus described by Smith Woodward :

Spines of two distinct types, the one evidently connected with the fins, the other free. Fin spines elongated, robust, more or less arched, irregularly rounded or oval in transverse section, except towards the unworn apex, which is compressed; base of insertion large, with the internal cavity

'Woodward, A. S. On a Carboniferous Fish Fauna from the Mansfield District, Victoria. Nat. Mus. Melbourne. Mem I, s906. P. I-32. In this paper the relations of the "Gyracanthidae" are definitely proved to be with Acanthodian sharks, upon the evidence of a complete skeleton of the remarkable Australian genus Gyracanthides [text fig. I7]. 
open for a considerable extent posteriorly. The longitudinal mesial line of the anterior face, except near the unworn apex, defined only by the superficial ornament, which consists of parallel, oblique, transverse, ridges, diverging in pairs from this line and inclined towards the inserted extremity; posterior face with a narrow unornamented area, sometimes bounded by a series of denticles on one side; unworn apex also destitute of ornament.

\section{Gyracanthus sherwoodi Newberry Plate 3 , figure 7}

is89 Gyracanthus sherwoodi $J$. $S$. Neziberry. U. S. Geol. Sur. Monogr. I6: II 9 , 1,l. s 8 , fig. 4 Fin spines attaining a length of about $15 \mathrm{~cm}$, laterally much compressed, gently arched and gradually tapering toward the apex; internal cavity open as a narrow groove for a considerable distance posteriorly; sides ornamented with numerous fine, parallel curved ridges, either irregularly pectinated or faintly nodose.

The only examples hitherto known of this species are those described by Newberry from a single boulder thought by him to have been derived from the Catskill of Tioga county, Pennsylvania. A few fragmentary spines displaying the same ornamentation and agreeing in form with Newberry's originals have been obtained from the Chemung group

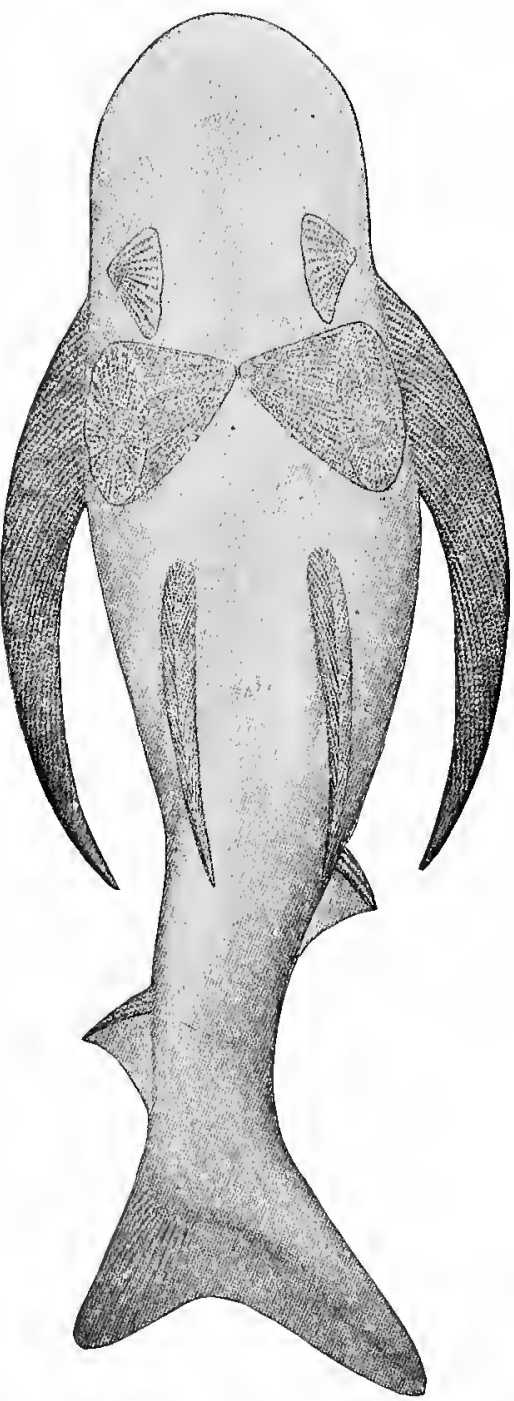
near IVarren, in the same state, one or two Fig. gr Gyracanthiles murrayi A.s. being preserved in the Museum of Comparative Zoology at Cambridge, Mass. Several Woodward. Restored drawing of fossil, much reduced, head and abrominal region seen from below, tail twisted to exlibit side view (After specimens from the Chemung of southern New York are also preserved in the State Museum at Albany. One particularly fine impression, shown in 
plate 3 , figure 7 , is labeled as having come from the top of Learn hill, in the northern part of Ischua township, Cattaraugus county, and there are others from near Portville and southeast of Olean, in the same State.

Formation and locality. Chemung beds (Chautauquan); New York and Pennsylvania. Catskill sandstone; Tioga county, Pennsylvania.

\section{Subclass DIPNEUSTI}

Fishes with partially ossified skeleton, numerous membrane or dermal bones, and persistent notochord; skull autostylic; dentition confined to inner bones of the mouth; gill clefts feebly separated, opening into a cavity with membranous operculum; paired fins archipterygial or reduced; median fins often subdivided; exoskeleton consisting of true bony tissue; sensory canals well developed.

The few existing Dipnoan" species, comprised by the fresh-water genera Neoceratodus, Protopterus and Lepidosiren, form a well nigh inappreciable remnant of a once flourishing and highly diversified race of lung fishes, whose maximum development and specialization occurred during the Devonic. One remarkable order comprising huge armored fishes passed entirely out of existence during the lowermost Carbonic, without leaving descendants. Such, at least, appears to be the most satisfactory interpretation of the group now commonly known as Arthrodires. Another order, that of Ctenodipterines, was conspicuous throughout the Paleozoic, and attained a higher degree of specialization along certain lines than is evinced by later forms. The geological history of the Sirenoid order, to which Ceratodus and its modern descendants belong, is not traceable with certainty earlier than the Triassic, although it is possible that some Paleozoic remains, known chiefly by the dentition, properly belong here. That primitive members of this order were in existence at least as early as the

I As pointed out by Haeckel, Boulenger and others, the term Dipnoi, first applied by Johannes Müller in 1845 for the group of lung fishes, is improperly so used, having been previously chosen by Leuckart as a name for Amphibians. There is no objection, however, to retaining the name Dipnoan as a vernacular equivalent of Dipneusti, and it is here employed in that sense. 
Lower Devonic follows as a necessary inference from regarding Sirenoids as ancestral to Arthrodires and Ctenodipterines. This view of their relations, however, is novel, and the considerations which make for its acceptance, and compel us to look upon Neoceratodus as an archaic survival of the primal Dipnoan stock, will be discussed under the general treatment of Arthrodires.

\section{Order ARTHFODIRA}

Dipnoans having a reduced number of dermal bones forming the cranial roof, arranged essentially after the same pattern as in Ceratodonts, and their dentition also paralleling modern forms. Dermal armor of abdominal region consisting of large plates, either in simple apposition with the head shield, or articulated with its posterior border by a pair of movable ginglymoid joints placed dorsolaterally. Column notochordal, but with distinct neural and haemal arches. Tail apparently diphycercal in the best known forms; paired fins rudimentary or absent; pelvis represented by a pair of sigmoidal or club-shaped plates, sometimes with an anterior ventral projection.

The remarkable group of armored Coccosteuslike fishes was originally united with Asterolepids by $\mathrm{M}^{\prime} \mathrm{Coy}$, in $\mathrm{I} 848$, in a single "family Placodermi," and for more than 40 years this arrangement was adhered to by writers generally, save for slight changes in the rank assigned to the main divisions. To Professor Cope belongs the merit of being the first naturalist to recognize the heterogeneous nature of this assemblage, and to initiate its disruption. In 1889 , he proposed the removal of Asterolepids from the class of fishes altogether, and at the same time referred Coccosteans provisionally to the Crossopterygii. ${ }^{x}$ Soon afterwards, however, following Smith Woodward's suggestion, the several families of Coccosteans were grouped, under the new name of Arthrodira, in a separate order of Dipnoans. ${ }^{2}$ This arrangement obviously implied, though it had not then been demonstrated, that the Arthrodiran skull was truly autostylic, and that a

${ }^{x}$ Cope, E. D. Synopsis of the Families of Vertebrata. Am. Nat. I889. ${ }_{23} 3: 856$.

2 Ibid, 1891. 25:647; also Syllabus of Lectures on Geology and Palaeontology. Phila. I89r. p. I4. 
maxillary arch was not developed. Another feature which influenced the novel association of Arthrodires with Dipnoans was the parallelism, previously noted by Newberry, ${ }^{\prime}$ between the dentition of Dinichthys and that of Protopterus. The absence of any indication of a hyomandibular bone, even in the most admirably preserved specimens, and of more than a single ossification in the lower jaw, were considered sufficient reasons for excluding Arthrodires from Teleostomes.

This provisional classification of Arthrodires with Dipnoans met with an indifferent reception on the part of most paleontologists, and was afterwards rejected by some of its early supporters, notably Traquair and Bashford Dean. It was even conceded by Smith Woodward himself a few years later, that "the systematic position of this extinct order is indeed doubtful." a Traquair's defection dates from Igoo, when he declared, in his Bradford address, ${ }^{3}$ in favor of considering Arthrodires as "Teleostomi belonging to the next higher order, Actinopterygii." The following year Dean expressed the radical view that they were not fishes at all, but representatives of a distinct class, called by him Arthrognathi, and conceived to have possible kinship with Ostracophori. ${ }^{4}$ It was even allowed that subsequent researches might demonstrate a union between Arthrognaths and Ostracophores, whereby the time-honored group of Placodermata would be restored. This last was a complete reversal of his former view that the "jaws, specialized dentition, fin spines, and highly evolved pelvic fins at once separate this group [Arthrodira] from the lowly Ostracoderms." 5

By far the most amplitudinous extension of the term Placodermata is that proposed by Otto Jaekel, in I902, whereby the Pteraspids, Tremataspids, Cephalaspids, Asterolepids and Coccosteans were all embraced within

r Newberry, J. S. O. Geol. Sur. Rep't Pal. I875. 2: I5. The suggestion is here advanced that Protopterus and Lepidosiren are lineal descendants of "Placoderms."

${ }^{2}$ Woodward, A. S. Outlines of Vertebrate Palaeontology. $\quad$ i898. p. 64.

3 Traquair, R. H. Vice Presidential Address. Brit. Ass'n Adv. 'Sci. Bradford meeting, Rep't. I900. p. 779 .

4 Dean, B. Palaeontological Notes. New York Acad. Sci. Mem. Igor. 2:113.

5 Idem. Fishes, Living and Fossil, N. Y. I895. p. I 30. 
a single group. $\quad$ This assemblage was modified a twelvemonth later, however, in that the two last named divisions were bracketed together under the head of "Temnauchenia," all of the others, together with Drepanaspids, Coelolepids and Birkeniidae, being collectively designated as "Holauchenia." ${ }^{2}$ Placoderms in this broadened sense were all considered by Jaekel to belong to fishes proper, and it was further maintained by him that Coccosteans were ancestral to Chimaeroids, an opinion in which he clearly stands alone. 'The only other author who has ventured to recognize any descendants from Arthrodires whatever is Newberry, who, as we have seen, imagined Protopterus to be a modern survival of Dinichthys.

We may now pass rapidly in review the minor fluctuations of opinion that are apparent during the last few years. Dr O. P. Hay, in his Catalogue of Fossil Vertebrata of North Amcrica, employs the term Placodermi for both Arthrodires and Asterolepids, placing them in the same subclass with Dipnoans. Arthrodires and Ostracophores are awarded each the rank of a separate subclass in the English edition of von Zittel's Textbook of Palaeontology, the author having disapproved of an association between Coccosteans and Dipnoans. In Mr C. T. Regan's remarkable paper of r 904, already referred to, the Placodermi are reestablished so as to include Coccosteidae, Asterolepidae and Cephalaspidae, all being united in a single order of Teleostomes. ${ }^{3}$ During the same year Professor Bridge expressed the view, in the volume on Fishes in the Cambridge Natural History, that Coccosteans are "a highly specialized race of primitive Teleostomi," and compared their cranial roofing plates with those of typical bony" fishes. The idea of a relation between them and lung fishes is dismissed in the following passage, found at page 537 of the work in question:

The Arthrodira have been regarded as armored Dipneusti, a view which is mainly based on their supposed autostylism and the nature of the

' Jaekel, O. Ueber Coccosteus und die Beurcheilung der Placodermen. Sitzungsber. Gesellsch. Naturforsch. Freunde. I902. p. 103.

${ }^{2} I d e m$. Ueber die Organisation und systematische Stellung der Asterolepiden. Zeitschr. deutsch. geol. Gesellsch. Mai-Protoko1l. I903. 55:58.

${ }^{3}$ Regan, C. T. The Phylogeny of the Teleostomi. Mag. Nat. Hist. Ann. ser. 7, 1904. I $3: 346$. 
dentition. But this autostylism has yet to be verified, and, if proved, the possibility that it may be a secondary feature, associated with the evolution of a peculiar dentition, must not be forgotten. Much more may be said for their claim to be regarded as a highly specialized race of primitive Teleostomi. Besides a well developed lower jaw, bones comparable to the elements of a secondary upper jaw are known, and in a general way the disposition of the cranial roofing bones, and the arrangement of the endoskeletal elements of the pelvic fins, tend to conform to the normal Teleostome type. In fact, Dr Traquair has expressed the opinion that the Arthrodira are Teleostomi and Actinopterygii. ${ }^{x}$

In his description of some Dinichthyid remains from Ohio, published in I 905, Mr L. Hussakof ${ }^{2}$ refers to them as "Placoderms," apparently using the term in its familiar acceptance. Their position is also left undetermined by E. Ray Lankester, in his interesting lectures on Extinct Animals, recently published in book form. ${ }^{3}$ Dr Lucas's popular treatise on Animals before Man in North America places them in association with lung fishes, in accordance with Smith Woodward's idea. One other popular handbook claims attention, not only because it is an extremely useful work covering the whole subject of fishes, but because of the author's extensive acquaintance with fossil as well as recent forms. We refer to President Jordan's Guide to the Study of Fishes [N. Y. I905], in the first volume of which, at page 582, the relations of Arthrodires are discussed in following wise:

These monstrous creatures have been considered by Woodward and others as mailed Dipnoans, but their singular jaws are quite unlike those of the Dipneusti, and very remote from any structures seen in the ordinary fish. The turtlelike mandibles seem to be formed of dermal elements, in which there lies little homology to the jaws of a fish, and not much more with the jaws of Dipnoan or shark.

The relations with the Ostracophores are certainly remote, though nothing else seems to be any nearer. They have no affinity with the true Ganoids, to which vaguely limited group many writers have attached them.

In his latest reference to this subject, however, he admits that they are of uncertain subclass. Compare, for instance, his description of Coccosteus angust us in Roy. Soc. Edinburgh Trans. I903. 40:732.

${ }^{2}$ Hussakof, L. Notes on the Devonic "Placoderm," Dinichthys intermedius Newb. Am. Mus. Nat. Hist. Bull. I905. 21:27-36. Also, more recently, Studies on the Arthro* dira, in the memoirs of the same institution. I906. 9: 105-54.

${ }^{3}$ Lankester, E. R. Extinct Animals. N. Y. x 905. p. 256. 
Nor is there any sure foundation to the view adopted by Woodward, that they are to be considered as armored offshoots of the Dipnoans.

Again, at page 445 of the same volume, this passage occurs:

These creatures have been often called ganoids, but with the true ganoids like the garpike they have seemingly nothing in common. They are also different from the Ostracophores. To regard them with Woodward as derived from ancestral Dipnoans is to give a possible guess as to their origin, and a very unsatisfactory guess at that.

Finally, reference may be made to two papers published lately by the present writer, ${ }^{,}$in which he endeavored to show that the dentition of Arthrodires belongs distinctly to the Dipnoan type, and that real homologies exist between their dermal cranial plates and those of the living Neoceratodus. Indeed, the modern form was held to bear as intimate structural resemblance to Coccosteans on the one hand, as to Ctenodipterines on the other, although conforming more nearly than either in certain respects to the hypothetical ancestor from which all three types - Ceratodonts, Arthrodires and Ctenodipterines - have been derived.

The position maintained in this last communication is adhered to in the present memoir, and it is believed that sufficient evidence has now been accumulated to sustain its correctness. Heretofore, in default of positive evidence, writers have been unable to demonstrate the truth of any one of the various conjectures put forward to explain the nature of Arthrodires. However plausible one or another of these may have appeared, however widely they have gained acceptance, it must be remembered that a suggestion remains a suggestion, and a hypothesis a hypothesis, until its correctness is fully demonstrated. Rightly is it said in one of Plato's Socratic dialogues:" "Mere beliefs or opinions are, like the statues of Daedalus, runaway things; not until they have been tied down by the chain of causal sequence do they stand fast and become in the true sense knowledge."

What constitutes this "reasoned interconnection" in the present case may be told in few words. In the first place we must anticipate a little by

I Eastman, C. R. Dipnoan Affinities of Arthrodires. Am. Jour. Sci. ser. 4, rgo6. 21: I3I-43. Idem. Mus. Comp. Zool. Bul. 1906. 50: I-30.

2 Meno, I59 D. 
saying that valuable enlightenment concerning the dentition of Arthrodires is furnished by the type of a new genus from the Portage of western New York, hereinafter described under the name of Dinomylostoma. This interesting form, transitional between Dinichthys and Mylostoma, acquaints us for the first time with the nature of the articulation between the lower jaw and head shield amongst Coccostean fishes; it displays portions of the Meckelian cartilage, still preserved in natural position; and the relations of this structure to the ossified mandibular elements - splenial and dental plate proper - are seen to be precisely as in modern Dipnoans. The lower jaw of Arthrodires is therefore proven to conform strictly to the Dipnoan type, a fact of cardinal importance for their classification. The upper dentition, also, is comparable in a general way to young stages of Neoceratodus; hence it may be affirmed with entire propriety that the dentition of the recent genus passes through an early Mylostomid stage. Further comparisons between Neoceratodus and typical Arthrodires, such as Coccosteus, Dinichthys and Mylostoma, establish a sound basis for the following propositions :

I The dermal plates forming the cranial roof in Arthrodires and primitive Ceratodonts have undergone corresponding reduction, and become arranged after essentially the same pattern.

2 Neoceratodus recalls throughout its entire organization, save only for the absence of dermal armoring, the principal features of Arthrodires; and no theory of parallelism is competent to explain the aggregate of these resemblances.

3 It is impossible to regard Neoceratodus as the degenerate descendant of bot/ Ctenodipterines and Arthrodires, nor of either of them singly, since it partakes of the characters of both. Community of origin is therefore necessarily presupposed for all three groups, there being no alternative explanation of their relations.

4 Arthrodires and Ctenodipterines may be regarded as specialized offshoots which diverged in different directions from the primitive Dipnoan 
stem, only the more generalized descendants of the latter having survived until the present day.

5 The primordial stock must have been autostylic, diphycercal, without a maxillary arch and dentigerous dentary elements, and with a Uronemuslike or Dipteruslike dentition; characters which do not permit us to ascribe the ultimate origin of Dipnoans to the Crossopterygii, but suggest rather a descent from Pleuracanthid sharks.

6 The recognition of Arthrodires as an order of armored Dipneusti precludes their association with Ostracophores in any sense whatever. 'The recently revived group of "Placodermata" is, therefore, an unnatural assemblage, and should be abandoned.

7 In the light of present information, the progressive modifications amongst early Dipnoans may be represented after some such scheme as follows :

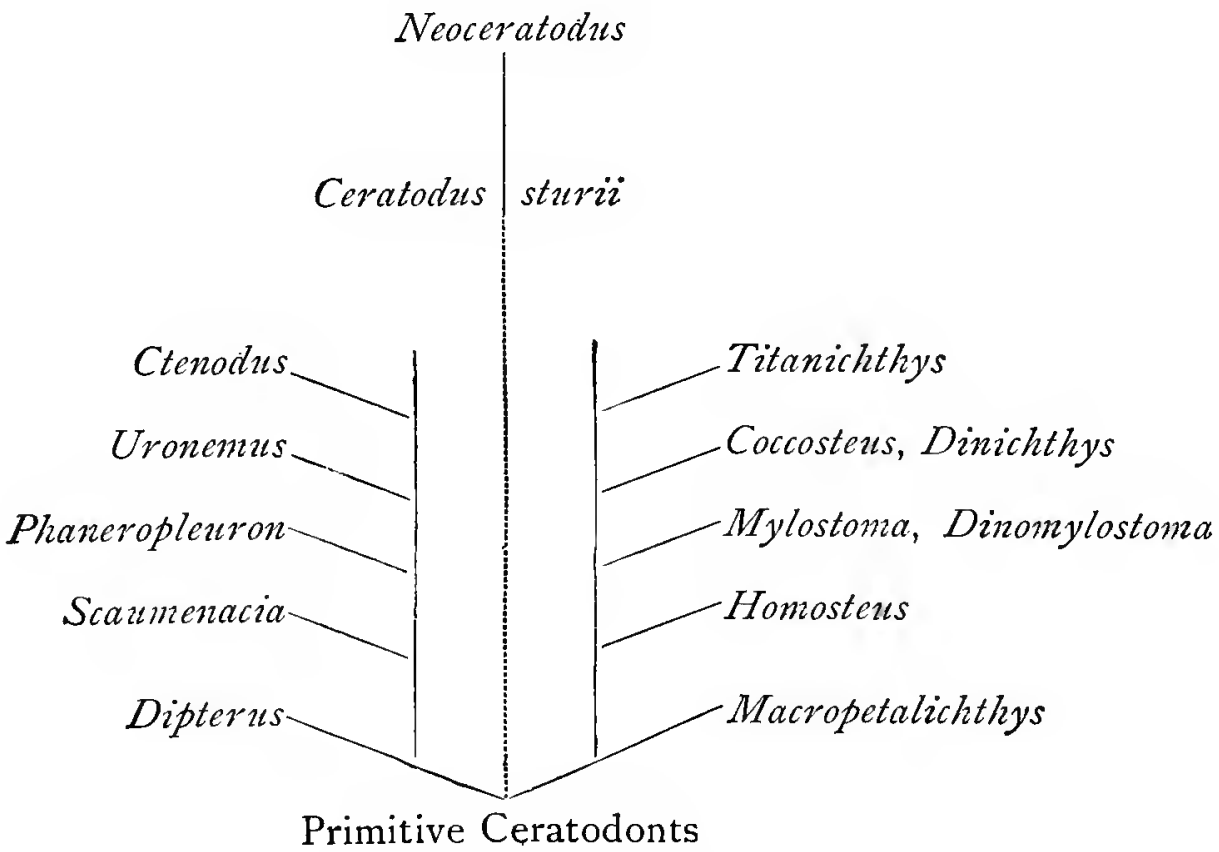

It would be superfluous to present here a fresh demonstration of the close structural agreement between Arthrodires and Ceratodonts. One 
point only need be developed a little more fully, perhaps, and that is the fact that Dinichthys and Mylostoma are related to each other in the same way with respect to their dentition as are Protopterus and Neoceratodus. This will appear from the following considerations.

Dentition of Dinichthys and Neoceratodus compared. It is recognized by all students that Neoceratodus, in comparison with other surviving lung fishes, represents a relatively early larval stage of development; nor does any one question that the trenchant dental plates of Protopterus and Lepidosiren are other than a mere variant of the Ceratodont type. This much being granted, it is but a short step further to see that the dentition of Dinichthyids has been similarly derived. Certainly no difficulty is offered by the so called "premaxillary" teeth of Dinichthys, which are the precise equivalent of the vomerine pair in modern Dipnoans. As for the characteristic crushing plates in the upper jaw of Ceratodonts, these occur normally in Mylostoma, but in Dinichthys become rotated so as to stand more or less vertically, their outer denticulated margins functioning against one another in opposite jaws like the blades of a pair of shears. An inkling as to how this modification was brought about is offered by the Triassic Cerat odus sturii, which may be taken to represent an incipient stage of metamorphosis. The dental plates of this form are observed to be turned considerably on edge, their marginal corrugations interlocking in opposite jaws when the mouth is closed, and a rudimentary beak being developed in front which recalls the well known forward projection in Dinichthyid mandibles.

As for the so called "maxillary" or "shear tooth" of Dinichthys, this corresponds clearly to the triturating upper (palato-pterygoid) dental plate of Ceratodonts, turned rather more upright than in C. sturii, and its anterior process or "shoulder" is represented by the forwardly placed ascending process of modern forms. In Arthrodires, as in other Dipnoans and higher forms, the functional lower jaw is formed by membrane plates which have ossified around the Meckelian cartilage. Distinct angular and articular elements appear to be wanting in Dinichthys, ${ }^{2}$ but the splenial is

'Dean, B. Fishes, Living and Fossil. N. I. I895. p. I33. 
strongly developed, supporting the dental plate sensu stricto in front, and being articulated posteriorly with the cranium by cartilage, as in Neoceratodus. But one interpretation can be given of the conspicuous groove which extends forwards along the inferior border of the splenial, passing underneath and to the inner side of the dental plate proper, and terminating near the symphysis. In it were lodged remnants of the Meckelian cartilage, precisely as in the living Protopterus. Intermandibular teeth have not been definitely proved to occur, although their presence would be in strict accord with embryological evidence, and the appearance of certain specimens has led some investigators to suspect that such teeth were developed; moreover, in Coccosteus, Diplognathus etc., we are confronted with a denticulated symphysial margin, the significance of which has not been explained. Finally, it should be noted that an approach to the Dinichthyid form of mandible is made even amongst Ctenodipterines, ${ }^{,}$and some of these also develop cutting edges, as in $\mathrm{S}$ a g e nod us perten u is, ${ }^{2}$ for example.

Dentition of Mylostoma and Neoceratodus compared. Our knowledge of Mylostoma received important additions a few years ago as the result of Dr Bashford Dean's investigation of the type species. ${ }^{3}$ Since then, however, fresh material has been brought to light which shows that this author was not entirely successful in determining the relations of the palatopterygoid dental plates in the unique specimen studied by him. Their true disposition has recently been ascertained beyond doubt to be as represented in the accompanying text figure $\mathrm{r} 8$, a similar arrangement holding true also for Dinomylostoma, and, interestingly enough, being repeated in early stages of Neoceratodus. This we have already alluded to in a preceding paragraph, by saying that Neoceratodus passes through a Mylostomid stage. One can hardly fail to appreciate the significance of this

${ }^{\mathrm{I}}$ Atthey, T. On Ctenodus obliquus, etc. Mag. Nat. Hist. Ann. ser. 4, 1875. 15: 300, pl. 19, fig. 2 .

2 Eastman, C. R. A Peculiar Modification amongst Permian Dipnoans. Am. Nat. 1904. 37:493-95.

3Dean, B. Palaeontological Notes. N. Y. Acad. Sci. Mem. igor. 2: ror-g. 
fact in considering the relations between fossil and recent forms. It has been shown by Semon ${ }^{\mathrm{T}}$ that the dental plates of the modern genus arise through concresence of conical denticles, which are at first disposed so as to form two pairs of palato-pterygoid plates, these afterwards fusing into one; and, thanks to this observation, we can readily account for what would appear at first sight to be a supernumerary pair in Mylostoma. Moreover, it will be noted that the peculiar posterior contour of the hindermost pair of plates in the fossil form is scarcely to be explained except as we regard it in association with, and conformable to, the usual pattern of palatopterygoid cartilage found in all Dipnoans. Amongst Ctenodipterines this

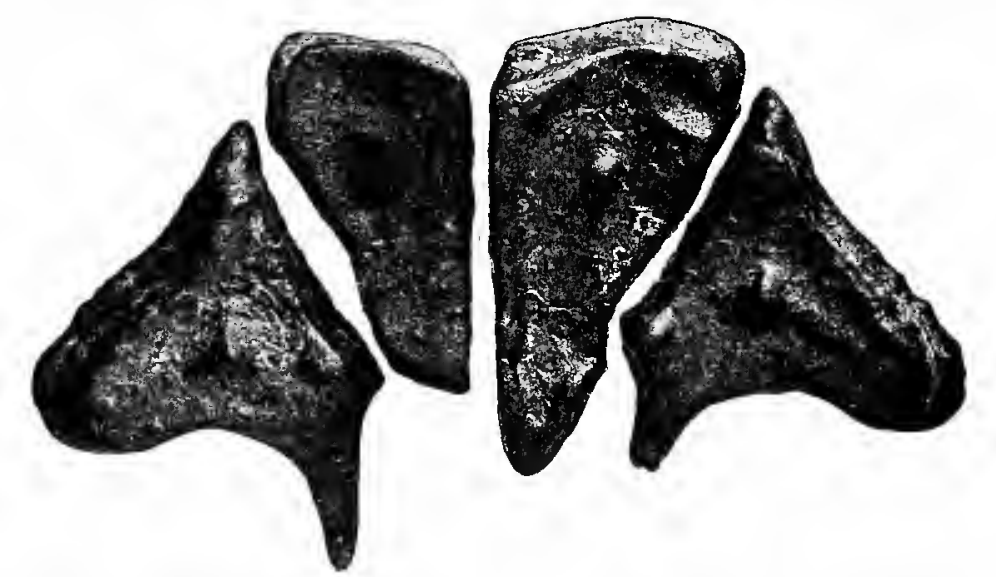

Fig. 8 Mylostoma variabile Newberry. Cleveland shale; Sheffield, $O$. Palato-pterygnid dental plates, arranged in nutural position, but belonging to different individuals. The vomerine pair is supposed to have been situated immedi.tely $i_{n}$ front, but no specimens undunbtedly assignable to this position are at present known. x ${ }^{2} \frac{3}{3}$

element is ossified, and passes under the name of "upper dentigerous bone," yet it preserves essentially similar outlines, and bears the stamp of a persistent feature.

The mandibles of Mylostoma betray unmistakable traces of a Ceratodont origin, for the dental plate properly speaking is even more sharply distinguished from the splenial than in Dinichthys or Dinomylostoma. The presence of intermandibular teeth would be in complete harmony with embryological evidence, and as a matter of fact certain detached teeth have

'Semon, R. The Zahnentwickelurs des Ceratodus forsteri. Zool. Forschungsreisen in Australien etc. Jena Denkschr. 1901. 4:115-33. 
been somewhat doubtfully interpreted as such by Newberry. ${ }^{x}$ The pair figured by him, however, have recently been ascertained to represent imperfect mandibular plates of an undescribed species of Mylostoma, and are proved to bave been firmly united in the median line. Under these conditions intermandibular structures are definitely excluded. Amongst Ctenodipterines, Synthetodus furnishes the only known example where symphysial teeth are permanently retained, thus paralleling an evanescent condition in Neoceratodus. Indeed, this very character leads one to suspect that the form in question belonged to primitive Ceratodonts, rather than to the Ctenodipterine order of Dipnoans.

Systematic arrangement of Arthrodires. Various stages of evolution are recognizable throughout the group, the most important being typified by (I) Macropetalichthys, (2) Homosteus and (3) different genera comprised by the families Coccosteidae, Mylostomatidae and Selenosteidae in order of progressive specialization. In the system of classification proposed by Bashford Dean, these stages find expression through the erection of three new "orders," the first and most primitive of which includes Macropetalichthys and Asterosteus, the second Homosteus, and the third all of the more highly specialized forms. Dean's arrangement of families, and for the most part, of genera as well, is probably as judicious as present known facts will allow; hence we have adopted it in the following section of the report, without, however, taking account of his larger divisions. His definition of one of them, as pointed out by Jaekel, ${ }^{2}$ includes structural characters which do not exist; and we may be reasonably confident that in none of them did the jaws operate by rotary movements, on which point Dean, and following him Hussakof, lay great stress.

\section{Family MACropetalichtimXIDAE}

Cranial shield much arched from side to side, completely inclosing the orbits, and extending over the nuchal region posteriorly. External surface covered with fine stellate tubercles which conceal the underlying sutures between dermal plates. Median series of plates but two in number, narrow

${ }^{2}$ Newberry, J. S. U. S. Geol. Sur. Monogr. I889. 16:165, pl. 16, fig. 4.

${ }^{2}$ Jaekel, O. Referat in Neues Jahrb. f. Min. Jahrg. I903. I: $34^{2}$. 
and elongate; external occipitals large; centrals divided, the two pairs on either side not meeting in the middle line. Pineal foramen inconspicuous, situated slightly in advance of a line joining the anterior borders of the orbits. Sensory canals forming large tubular excavations in the bone, opening at the external surface by a continuous narrow slit or by a double row of pores. Parachordal cartilage and notochordal sheath ossified. Dental plates and abdominal armor unknown.

The typical genus of this family is Macropetalichthys, known by a single American, and one or two European species. Some others, as yet undescribed, are reported by Jaekel from the Eifel Devonic, and at the same time the form described by Kayser as M. pruemensis is made the type of a new genus. ${ }^{x}$ The members of this family evidently stand in somewhat close relation with Homosteus, all of these forms having the head shield prolonged posteriorly over the nuchal region, and exhibiting a decidedly primitive arrangement of cranial plates. In this latter respect it is interesting to note that the median series of plates are reduced to the same number as in Neoceratodus.

\section{Genus MACRO - ETALICHTHYS Norwood \& Owen}

This genus, certainly one of the most primitive of Arthrodires, is represented in this country by the typical species, which was first described under the name of M. rapheidolabis. The history of our acquaintance with the genus is interesting, and may be recapitulated as follows: Specimens of the head shield seem to have been first discovered by Mr Joseph Sullivant, of Columbus, O., as early as 1836 , though they were not brought to the attention of students until several years later. In 1846 Messrs Norwood and Owen published a Description of a new Fossil Fish, from the Palacozoic Rocks of Indiana, ${ }^{2}$ in which the generic and specific titles were properly proposed. The type specimen of M. rapheidolabis was exhibited before the American Association for the Advancement of Science

'Jaekel, O. Ueber Coccosteus und die Beurtheilung der Placodermen. Sitzungsber. Gesellsch. Naturforsch. Frennde. rgo2. p. I13. Ihid. Jahrg. 1906. 73-85.

$=$ Am. Jour. Sci. [2] I 846 . r: $367-7$ r. 
at the Cincinnati meeting, in $185 \mathrm{I}$, where it was examined by Professor Louis Agassiz. Newberry, in 1862 , mentions having seen a cast of the same, but states that the original itself had disappeared. ${ }^{2}$ However, it still remained in existence, and was finally acquired by the University of Missouri. In 189 I it was redescribed by Cope, ${ }^{3}$ most fortunately for science, since only a few months after its return to Missouri it was destroyed by fire together with the entire contents of the museum to which it belonged.

The same year that Norwood and Owen described the type species, Hermann von Meyer ${ }^{4}$ published a few notes on the fossil fishes from the Eifel Devonic, one of which received the name of Placothorax agassizi. This was soon afterwards figured and described by the same author, ${ }^{5}$ but it was reserved for Newberry, in 1857 , to point out its identity with Macropetalichthys. ${ }^{6}$ Von Meyer's specimen was entirely denuded of its superficial ornamentation, a circumstance which prevented him, as he tells us, from associating with it a second specimen which he described under the name of $\mathrm{Physichthys}$ hoeninghausii; ${ }^{7}$ nevertheless he conceded that they might possibly prove to be identical. He also pointed out that fragments of the same nature and from the same locality as these had been described by Agassiz under the title of Asterolepis hoeninghausii. Von Meyer's type specimens of "Physichthys" afterwards passed into the possession of Dr L. Schultze, from whom they were purchased in $187 \mathrm{I}$ by the Museum of Comparative Zoology at Cambridge, Mass. Here they were examined by Dr A. Smith Woodward, who was the first to demonstrate the true nature of "Physichthys." 8 A second European species was brought to light in 1880 , and named M. prue-

$x$ Am. Ass'n Adv. Sci. Proc. 1851. 5: 179 .

${ }^{2}$ Am. Jour. Sci. [2] I862. 34:76; U. S. Geol. Sur. Monogr. 1889. I6:27.

3 U. S. Nat. Mus. Proc. I891. I4: 449-56.

4 Neues Jahrb. für Min. I 846 . p. 596-97.

5 Palaeontographica I 847 . I: 102-4, pl. I2, fig. I.

${ }^{6}$ Nat. Inst. Bul. I 857 . p. II 9.

7 Palaeontographica I 855 . 4: $80-83$, pl. I5, fig. I-5.

${ }^{8}$ Geol. Mag. [3] I8go. 7:459; also Cat. Foss. Fishes Brit. Mus. I891. pt 2, p. 303. 
mensis by Dr E. Kayser. ${ }^{1}$ It was further described and illustrated by Professor A. von Koenen in 1895 , together with an imperfectly preserved Bohemian cranial shield, designated as Holopetalichthys novaki. Quite recently, as we have already seen, Dr Otto Jaekel expressed the opinion that the type of M. pruemensis should be held to represent a distinct genus.

We may now trace the progress that has been made in investigating the typical American species, which had not ceased to attract attention. Professor Newberry contributed to the first number of the Annals of Science, published October 15, 1852, a brief account of "Fossil Fishes from the Cliff Limestone," in which he described and figured an unusually perfect specimen of Macropetalichthys. Although the position of the principal plates and their centers of ossification are clearly portrayed in this early woodcut, the significance of these features was not understood, and no account was taken of them in later restorations. Newberry's views as to the relations of his fossil are thus stated: "This is evidently the cranium of a ganoid fish, allied to the Asterolepis of Europe, and is probably identical with that described by Owen and Norwood. I say probably, for although the general outline of the cranial plates seems to establish an identity, their description would indicate entire distinctness - a discrepancy which I am inclined to attribute to the imperfect preservation of their specimen."

Other crania were exhibited by Newberry before the American Association for the Advancement of Science at the Cleveland meeting in 1853 , and in 1857 descriptions were given of two new species, the so called "Agassichthys sullivanti and A. manni," which were at that time considered to be generically distinct from Macropetalichthys." A few years later, however, Newberry returned to the belief that the two species of "Agassichthys," and also the type of von Meyer's "Placothorax," all belonged to Norwood and Owen's genus. ${ }^{3}$ Subsequently he found it diffi-

\footnotetext{
× Zeitschr, deutsch. geol. Ges. 1880. 32:678.

a Nat. Inst. Bul. 1857. p. I I9-24.

3 Am Jour. Sci. [2] i 862. 34: 74, 75 .
} 
cult to maintain the distinction between M. sullivanti and M. manni, and was "disposed to consider the differences which they exhibit as probably due to age or sex." " A final statement of Newberry's views regarding the structure and relations of Macropetalichthys appeared in his Monograph on Palaeozoic Fishes of North America, published in i 889, the genus being compared with existing sturgeons, and sensory canals being still mistaken for sutures. Cope, ${ }^{2}$ in his review of his friend's monograph, denied that this genus was in any way related to modern ganoids, and redescribed its characters the following year. Some additional details were pointed out by the present writer in 1897 , and an attempt was made by Dean, in his important memoir of I9OI, to homologize the cranial plates of Macropetalichthys with those of other forms. Aside from the reviews of this memoir which appeared in this country and abroad, nothing has been contributed to the literature of the American species within the last few years.

\section{Macropetalichthys rapheidolabis Norwood \& Owen}

Plate y, figure 5; plate $I_{1}$; text figures 19-2I

r846 Macropetalichthys rapheidolabis Norwood \& Owen. Am. Jour.

Sci. [2] r : 37 I

I85 "Buckler of ganoid fish" L. Agassiz. Am. Ass'n Adv. Sci. Proc. 5: 179

r852 Macropetalichthys sp. J. S. Newberry. Ann. Sci. I, p. I 2

1857 Agassichthys sullivanti $J$. S. Nezeberry. Nat. Inst. Bul. p. I24

1857 Agassichthys manni $J$. S. Newberry. Nat. Inst. Bul. p. I22, woodcut

r 862 M a cropetalichthys manni and M. rapheidolabis. Am. Jour. Sci.

[2] 34:75,76, woodcut

1873 M acropetalichthys sullivanti J. S. Nezoberry. O. Geol. Sur. Rep't

Palaeont. v. 1, pt 2, p. 294, pl. 24, 25, fig. I

1889 M acropetalichthys sullivanti $J$. S. Newbery. U. S. Geol. Sur.

Monogr. 16:44, pl. 38, fig. I, 2

1890 Macropetalichthys sullivanti E. D. Cope. Am. Nat. 24:846

r 89 r Macropetalichthys sullivanti and M. rapheidolabis $E$. $D$.

Cope. U. S. Nat. Mus. Proc. I4: 449-56, pl. 29, 3o, fig. 5

× Ohio Geol. Su1. Rep't. Palaeont. 1873. v. I, pt 2, p. 295.

"Am, Nat. 1890. 24:844-47. 
I 897 Macropetalichthys sullivanti and M. rapheidolabis $C . R$. Eastman. Am. Nat. 31:493-99, pl. I 2

Igor Macropetalichthys sp. B. Dean. N. Y. Acad. Sci. Mem. v. 2, pt 3, p. 119 , text fig. 12

Head shield suboval, regularly arched from side to side, attaining a maximum length of about $25 \mathrm{~cm}$, and width across the posterior border of about i $7 \mathrm{~cm}$. Ornamentation consisting of fine, closely crowded stellate tubercles, sometimes displaying concentric arrangement. Of the two pairs of small centrals, which are separated from each other by the median occipital, the anterior takes part in the orbital border and is not traversed by sensory canals. Pineal plate pierced by an inconspicuous foramen, and apparently equivalent to the so called anterior median element or " mesethmoid" of Neoceratodus. Parasphenoid much expanded in front, posteriorly produced, resembling in a general way that of Ctenodipterines and Sirenoids, but considerably less ossified.

Preorbital sensory canals lyrate, and confluent in the middle line with the sharply angulated exoccipito-central system. The postorbital canal extends from the inferior border of the orbits to the center of the marginal plates, where it turns abruptly inwards and continues in a straight line to meet the exoccipito-central canal at the point of its angulation. The latter disappears beneath the surface of the external occipital plate close to the hinder margin of the head shield.

Speaking entirely within bounds, it is not too much to say that the characters of this long misunderstood genus and species fail of comprehension, or at least of satisfactory analysis, save as they are brought into relation with those of modern Dipnoans, and interpreted through comparison with them. Many students have puzzled over the cranial osteology of Macropetalichthys and the allied genus Asterosteus, of which only the median series of plates are known; but accumulation of details has resulted only in greater perplexity. Were a moral to be drawn from this state of affairs, and others like it, it would be this: However diligently facts may be collected, however attentively studied, they possess of themselves no intrinsic value; their usefulness lies only in the measure that we are able to appre- 
ciate their significance, and to draw from them generalizations. Intolerably barren must be those lines of inquiry which result in no broad conclusions. Natural science, however, and especially paleontology, imposes upon us this difficulty: for an hour or two of synthesis, years of patient application in the study of facts are required.

That which has hitherto been puzzling in Macropetalichthys and Asterosteus is the absence of a standard of comparison or other clues by means of which their characters acquire significance; they must needs remain unintelligible until brought into adjustment with other definitely known facts. Newberry, as we have seen, went widely astray in imagining these forms to be ancestral to modern sturgeons. Cope's keen insight led him immediately to perceive the resemblances between Macropetalichthys and Dinichthys; and in suggesting a comparison between the former and Neoceratodus, he actually hit upon - though without adequately realizing it - a solution of the whole matter. Holding within his grasp the key to a correct interpretation of the Arthrodiran skull in all particulars, one regrets that he did not consistently apply it, instead of attempting vainly to establish homologies with the skull of Stegocephalians. Only in one respect does he point out similarity of structure between Macropetalichthys and modern Dipnoans, and this relates to the underside of the head. The parasphenoid was correctly identified as such, and observed to have the usual Dipnoan outline; but he was less happy in determining the relations of the so called "cerebral chamber" of Newberry, and the structures termed by him "nuchal elements." Cope's " nuchal plate," or "dorsal plate" as it was called by Dean and Eastman, was further misinterpreted by the last named authors in that it was held to represent collectively the dorsal body plates of other Arthrodires, Dean's definition of "Anarthrodira" being based upon this view. Indeed, it must be said frankly that serious misapprehension has existed in the minds of all students, including the present writer, concerning the structures seen within the interior of the head shield in Macropetalichthys. As in the case of the cranial buckler itself, they only become intelligible through comparison with surviving Dipnoans, as will presently be shown. 
Cranial osteology. The arrangement of dermal roofing plates in the cranial buckler of M. rapheidolabis is shown in the, restoration given herewith and also observable in the head shield represented in plate II.

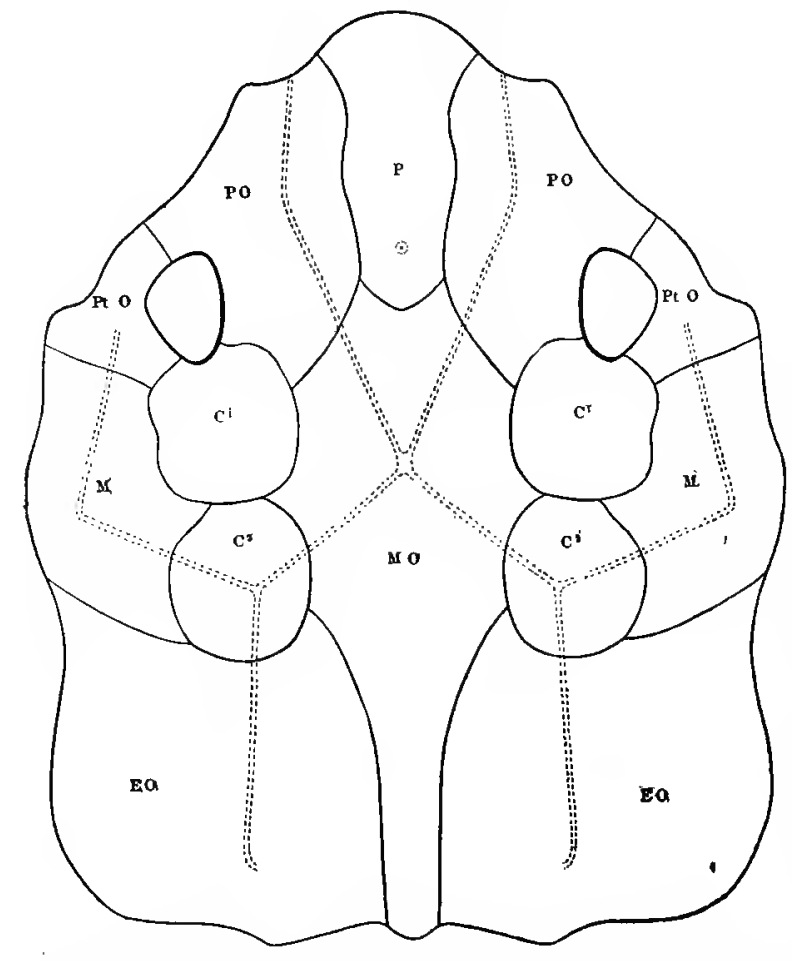

Fig. Ig Restoration of Macropetalichthys showing arrangement of iig. 19 Restoration of Macropetalichthys showing arrangement of
cranial plates and course of sensory canals, $x / 3 / 3 . C^{2}, c^{2}=$ divided by the orbits, but in Macropetalcentrals; $E O=$ external occivital; $M=$ marginal; $M O=$ median occipi-
tal $; P=$ combined pincal and rostral, corresponding to anterior median unpaired plate in Neoceratodus ; $P O=$ preorbital ; $P t O=$ postorbital

Referring to text figure 24 for comparison, it will be seen that the disposition of these elements corresponds in a general way to the pattern presented by Neoceratodus. Especially is this true of the median series of plates, the hindermost of which is elongated nearly to the same extent as in Homosteus. Other points of agreement between the form under discussion and Homosteus consist in the elongation of the external occipitals, and inclosure of the orbits within the head shield. In more specialized forms, the preorbital and postorbital plates are merely notched ably also in Asterosteus, these two plates unite to form their external border.

A conspicuous difference between Macropetalichthys and other Anthrodires, one which has proved a stumbling-block to a correct understanding of the cranial osteology, lies in the fact that the central elements are divided so as to form two small plates on either side immediately back of the preorbitals; these are placed one behind the other, the two pairs being separated from contact with each other in the median line by the elongated median occipital plate, very much in the same way as in Neoceratodus. That the 
plates here called centrals are correctly identified as such is evident from the following reasons: first, the two pairs together occupy the usual position of the centrals with reference to the preorbital plate in front, and to the postorbital and marginal

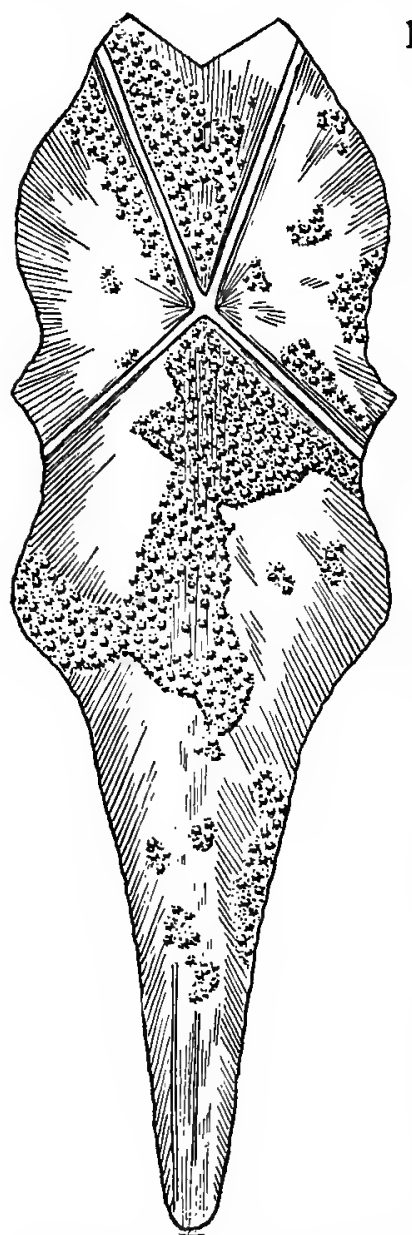

Fig. 21 Detached median occipital plate of Macropetalichthys showing sensory canals and partially deMus. Comp. Zool. Nat. size figure $2 \mathrm{I}$.

Evidence of the primitive nature of this genus, as compared with other Arthrodires, is furnished by the following characters, which point to a survival of embryonic or ancestral conditions: (I) continuity of the sensory

plates externally. Secondly, they are proved to be such by the disposition of sensory canals. Imagining the suture line as obliterated between the two independently ossified plates on either side, we shall have a single pair of elements occupying the same relative position as in Homosteus. The posterior moiety of this plate is seen

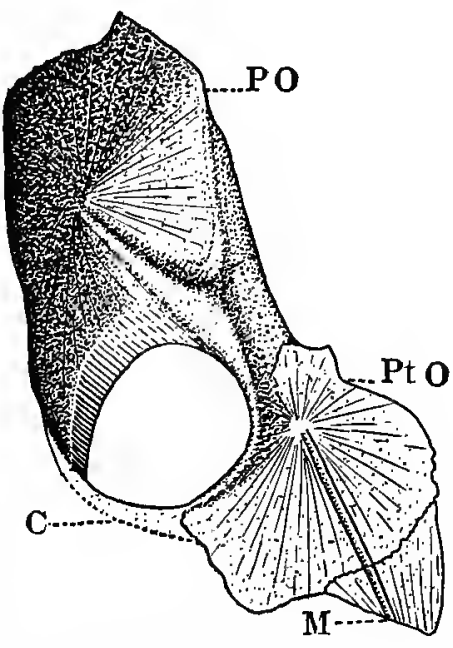

Fig. 20 Orbital portion of cranial shield of Macropetalichthys, viewed from the cerebral aspect. $C=$ margin of anterior central ; $M=$ marginal ; $P O$-preorbital ; PtO $=$ postorbital. Original in American Museum. Nat. size to be traversed by three different canal systems, identifiable with those called by Dean the preorbital, postorbital and occipital. Now, in the head shield of all Arthrodires so far as known, the central is the only plate traversed by all three of these canals. The preorbital and postorbital systems are sometimes confluent in other forms, but the occipital (or more properly, the exoccipito-central) does not unite with these other systems save only in Macropetalichthys. A detached specimen of the median occipital showing confluent canal systems is represented in text 
canal systems: (2) discreteness of the central elements and their separation on either side of the middle line by the median occipital; (3) reduced number of median series of plates; and (4) absence of any evidence of articulation or other connection between the head shield and dorsal body plates.

We have next to speak of the configuration of the basis cranii, by which term is understood, of course, not the inner surface of the cranial buckler, but the floor and posterior wall of the chondrocranium, the passageway provided for the initial portion of the vertebral axis, ossified parachordal cartilages, and the greatly elongated parasphenoid which forms the roof of the mouth. In the first place it should be noted that a bony extension of the external occipitals is developed along the posterior margin of the head shield in the form of a thin lamina or septum which extends nearly vertically downwards into the soft parts until reaching the level of the parasphenoid, with whose hinder extremity it joins. It is along the plane of this septum that the exoccipito-central canals penetrate downward and inward from the outer surface by means of funnel-shaped openings, the interior of which is filled with cancellated bony tissues. The function of the posterior septum seems to have been to impart rigidity to the arch of the head shield, and to serve as a partial support for the parasphenoid

The last named element resembles in a general way the familiar lozenge-shaped bone in Dipterus and modern Dipnoans, but is remarkable for its great expansion in front, where it occupies nearly the entire width of the head shield. Becoming narrower in the occipital region, it is continued backward as far as the posterior margin in the form of an arched laminar plate, not unlike that of Neoceratodus in form, upon which rests the parachordal cartilages and notochordal sheath. This hinder portion of the parasphenoid was interpreted by Cope as consisting of a pair of distinct elements, called by him the "lateral alae of the axis," or, in another place, "descending osseous laminae", but it is clear from well preserved specimens that only a single ossified element is attached to the floor of the cartilaginous cranium. A right understanding of this feature shows that in the form under discussion the parasphenoid is produced posteriorly to the same 
extent as in Neoceratodus and Lepidosiren; hence Cope's statement requires rectification when it is said that the parasphenoid in modern forms is abnormally produced behind. The extreme thinness of the bone in its anterior portion stands in decided contrast to the solidly ossified plate of Ctenodipterines, and it is further noteworthy that no specimen has yet enlightened us as to its relations with the palato-pterygoid cartilages. Near the point of its greatest constriction, in what corresponds to the position of the quadrate bone, is a well marked oval concavity, described by Cope as a "glenoid fossa"; and this may not improbably be looked upon as having served for attachment of the mandibular suspensorium. Nothing whatever is known of the characters of the latter, nor of the dentition; and accordingly these structures are inferred to have been cartilaginous.

Reference has been made to the tubular sheath which inclosed the notochord, and this we have stated to be supported below by the narrow posterior projection of the parasphenoid, miscalled by Cope "descending axial alae." The region traversed by the chordal sheath within the interior of the head shield has been variously interpreted, Newberry having described it as a "cerebral," and Cope as a "nuchal" chamber, both authors evidently regarding it as completely closed on all sides. As a matter of fact, the space designated by these writers as a "chamber" was closed at either end by thin osseous partitions, and above by the cranial roof ; but it was clearly open below on either side of the constricted portion of the parasphenoid. We can not imagine this partially inclosed space to have been the seat of any organ, although likely enough it contained fatty matter. Bearing in mind these differences of interpretation, it may be profitable at this point to examine Cope's account of the conditions observed by him in the holotype of the species, since unfortunately destroyed by fire. The following extract occurs at page $45^{2}$ of the article already quoted:

Turning now to the inferior aspect of the skull, we observed, at the

x"The parasphenoid in both Lepidosiren and Ceratodus is produced abnormally, and it is only necessary to imagine this part to be reduced to its normal length to have the conditions found in Macropetalichthys." [Cope, E. D. On the Characters of some Palaeozoic Fishes. U. S. Nat. Mus. Proc. 189r. r 4: 455] 
middle line of the inferior-posterior border, a wide, upward excavation, looking backwards and downwards. It rapidly contracts into a groove with an angular superior middle line. Whether this groove is part of a tube can not be ascertained, owing to the loss of the bony tissue on each side and below, but it may be only the apical angle of a roof-shaped space, whose lateral slopes are produced on each side, sloping well downwards and outwards. These sloping faces of the matrix represent a pair of osseous plates, which descended on each side from the sheath of the myelon and chorda dorsalis, for the latter occupied this position in the groove already described. Such a structure would indicate the presence of a number of fixed vertebral elements, such as exists in the chimaeras, the rays, and the sturgeons. . . . At the point of junction of the parasphenoid with the lateral alae of the axis is situated what I suppose to be the foramen magnum. It is the direct continuation of the groove already described, and, being floored by the parasphenoid, has a triangular section. There is no trace here of a fossa for the chorda dorsalis, nor of an occipital condyle, nor is it probable that either existed at this point. The parasphenoid is thin, and there are no indications of teeth to be observed on it.

It remains for us to state that the thin, vaulted and backwardly curved partition which closed the so called "cerebral chamber" in front is in reality nothing more nor less than the posterior wall of the chondrocranium. It is proved to be such by the notochordal opening above described; by its form and position, which are extremely suggestive of Dipterus ; ${ }^{\star}$ and by its suspension from the cranial roof in a manner recalling that in Neoceratodus. It was, however, but slightly ossified, the bone substance being everywhere thin, and no distinct exoccipital plates being formed about the foramen magnum. Nothing can be stated of the lateral walls of the chondrocranium, for the reason that they have not been observed in any specimen yet discovered; and it is quite likely that they were unossified. Appearances in Chelyophorus and Homosteus lead us to anticipate that further details may be forthcoming in regard to the chondrocranium and parachordal cartilages than is possible to learn from the less ossified condition of these parts in Macropetalichthys.

Abdominal armoring. Neither in this nor other species of Macropetalichthys, nor in the allied genus Asterosteus, have plates been found in

${ }^{x}$ Traquair, R. H. On the genera Dipterus, Palaedaphus, etc. Ann. Mag. Nat. Hist. ser. 5. I878. 2:5, pl. 3, fig. I. 
natural association with the head shield, or even in the detached condition, which can be interpreted with any degree of assurance as belonging to the dermal covering of the trunk. Analogy with other Arthrodires is indeed suggestive of the development of body armor; but on the other hand regard must be paid to the fact that no indications of overlap nor of an articular joint are visible along any portion of the posterior margin, and that the sensory canals stop short of it, whereas in other genera they are continued across the cleft between head shield and body armor. Conclusions based upon negative evidence are liable at any moment to be overturned by new discoveries; but in the present case this is the only class of evidence available, and the inference to be drawn from it is that the most primitive Arthrodires resembled Ceratodonts in being unprotected by abdominal armor. In all groups the development of an extensively ossified exoskeleton is looked upon as evidence of specialization. Its nondevelopment amongst forms that are clearly primitive in other respects would be, therefore, in nowise startling. Moreover, it should be remembered that within a single family of Ostracophores, Pterichthys is scaled, Bothriolepis naked.

In view of the remarks that have just been offered it is scarcely necessary to say that the view formerly entertained by the present writer, and more fully developed by Dean in his definition of "Anarthrodira," according to which all that portion of the head shield lying posterior to the chondrocranium corresponds to the dorsal body plates of typical forms, is now rejected as erroneous. The median and external occipital plates in this species are not superimposed upon a separate system of underlying plates, and whatever notion may have existed to the contrary may be set down to deceptive appearances. Thus, the plates called by Newberry "parietal," "squamosal," and "epiotic," in the region covered by the external occipital, have no real existence, the supposed sutures between them being merely the impressions of oblique ridges and other markings of the single large plate which forms the posterolateral border of the head shield. The disso. ciated elements belonging to a single inclividual are shown in plate 9, figure 5 . 
Formation and locality. Onondaga limestone; Leroy, N. Y. Columbus and Delaware limestones; Ohio. "Corniferous" limestone; Indiana and (?) Canada.

Macropetalichthys agassizi (von Meyer)

I 845 Asterole pis hoeninghausii L. Agassiz (errore). Poiss. Foss. V. G. R. p. I $30, I_{47}$, pl. $3 \circ$ a, fig. Io

I $846 \mathrm{P} 1$ a c othorax agassizi H. von Meyer. Neues Jahrb. für. Min. p. 596

I847 Placothorax agassizi $H$. von Mever. Palaeontogr. I: 102, pl. 12, fig. I

I 855 Physichthys hoeninghausi $M$. von Meyer. Palaeontogr. 4: 80, pl. I5,

fig. I-5 (non figs. 6-II)

I857 Agassichthys agassizi $J$. S. Netwbery. Nat. Inst. Bul. p. I I9

I873 Macropetalichthys agassizi $J$. S. Newberry. O. Geol. Sur. Rep't,

Pal. v. I, pt 2, P. 29I

I 895 Macropetalichthys agassizi $A$. von Koenen. Abhandl. Ges. Wiss.

Göttingen, 40: 22, pl. 4, fig. 3

Reference has already been made to the fact that the type of Hermann von Meyer's Physichthys hoeninghausii is now the property of the Museum of Comparative Zoology at Cambridge, Mass. Although incomplete, the part that is preserved shows several of the cranial elements very distinctly, and also the narrowed posterior portion of the parasphenoid which supports the notochordal sheath. This is deeply channeled in the median line for the passage of the notochordal sheath, and is concentrically striated in the same manner as the vertical lamina which descends from the posterior margin. The sheath itself exhibits no trace of segmentation, and, like that in the type species, is of remarkably small diameter.

Formation and locality. Middle Devonic; Eifel district, Germany.

\section{Genus Asterosteus Newberry}

An imperfectly definable genus, known only by the median series of cranial plates, but apparently closely approaching Macropetalichthys in structure. Ornamentation consisting of large, rounded, stellate tubercles, very irregular in size and arrangement; sensory canals indistinct; a pineal foramen, and also a pair of large oval openings of unknown significance present in the interorbital region. 


\section{Asterosteus stenocephalus Newberry}

1875 Asterosteus stenocephalus J. S. Newberry. O. Geol. Sur. Rep't, Pal. v. 2, pt 2, p. 36, pl. 54, fig. I

1889 Asterosteus stenocephalus $J$. S. Newberry. U. S. Geol. Sur. Monogr. 16:45, pl. 30, fig. I

I89r Asterosteus stenocephalus $A$. S. Woodward. Cat. Foss. Fishes Brit. Mus. pt 2, p. 3 I 2

Only a few examples are known of this species, none of which display the entire width of the head shield; accordingly, previous descriptions which represent the latter to be narrow and elongate are to be understood as applying only to the median series of plates, between which sutures are not distinctly traceable. The large, mesially placed openings between the orbits are regarded by Woodward as nasal, an interpretation which we are inclined to consider extremely doubtful in view of the invariable position of the nasal openings in other Arthrodires, Sirenoids and Ctenodipterines. The posterior flangelike projections on either side, called by Newberry "condyloid prominences," correspond to the semicircular ridges just back of the quadrate region on the inferior aspect of the skull in Macropetalichthys, and may have served for the attachment of the mandibular suspensorium. Jaws and dental elements unknown.

Formation and locality. Columbus and Delaware limestones; Ohio. Possibly also in the Onondaga limestone of New York.

\section{Family coccosteIDAF}

Cranial shield consisting of few elements, viz, a median and two external occipital plates, in front of which is a single pair of large centrals more or less in contact along the median line; these are in turn preceded by a pair of large preorbitals, which are either wholly or partially separated from each other by the azygous pineal and rostral ("ethmoid") elements; posterolateral border of the shield formed by the marginals and postorbitals. Orbits not completely inclosed within the shield, bounded inferiorly by a single suborbital plate, behind which occur one or two opercular elements. Upper dentition consisting of a pair each of vomerine and palato-pterygoid 
elements (commonly interpreted, however, as "premaxillaries" and "maxillaries"), the latter with trenchant functional margin, often serrated or denticulated. Lower dental plate, when ossified, intimately fused with the forward portion of the mandible, turned in upright position with sharp cutting edge, often serrated or denticulated like the upper. Symphysial margin also sometimes denticulated.

The structure of the typical genus, Coccosteus, is so well known from the classic researches of Pander, Traquair and later writers, that further description of it here would be superfluous. It furnishes a most valuable standard of comparison for referring the detached plates of other Arthrodires to their proper position, and for correlating the numerous minor variations observed in different members of the group. Interest centers in it also from the fact that this is commonly looked upon as the progenitor of later, much larger, and more highly specialized genera, occurring chiefly in this country, the best known examples of which are Dinichthys and Titanichthys. Owing to their intimate relations to Coccosteus, these two genera are retained in the same family with it. We have already had occasion to note the close structural agreement between Coccosteids and existing Dipnoans, more particularly as regards their dentition and cranial osteology, hence we need not dwell upon these points further in this connection.

No traces of axial segmentation have been observed in any member of this family, nor are there ossified ribs, Jaekel's representation to the contrary notwithstanding. ${ }^{x}$ There is one dorsal fin, the tail tapers gradually and to all appearances was diphycercal, but definite information concerning the caudal and anal is still lacking. Traces of pelvic fins occur, and a pair of short deep plates lying immediately in front of the ventral armor in Coccosteus has been interpreted as representing the pectoral arch. Nevertheless, positive evidence of the existence of pectoral fins has not as yet been forthcoming, and the so called pectoral spine or "Ruderorgan" in Coccosteus and Brachydirus is possibly the equivalent of the fixed spinous

I Jaekel, O. Ueber Coccosteus und die Beurtheilung der Placodermen. Sitzungsber. Ges. Naturf. Freunde. 1902. p. I07, restoration. 
process in Phlyctaenaspis, Acanthaspis etc. At the same time it is worthy of remark that both in form and position it is not wholly dissimilar to the rodlike operculum inferius, as Fürbringer calls it, of Neoceratodus. This author's observation that the two opercularia of the recent form are sometimes fused into a single piece acquires significance on recollecting that only a single opercular element is known to occur in most Arthrodires. ${ }^{2}$ Jaekel is the only author who has reported the occurrence in Coccosteus of two opercula, this being the normal number amongst Dipnoans, as already stated.

\section{Genus coccosteus Agassiz}

Of the four American species that have been referred to this genus, only one, C. can adensis Woodward, is satisfactorily known, the others being represented by detached plates exclusive of the head shield. To C. occidentalis, described in the first instance by Newberry from the Corniferous limestone of Ohio, are possibly to be referred a few isolated fragments occurring in the New York Mesodevonic, and it has been further surmised by the original author that the dental plates known as Liognathus spatulatus belong to the same species. In plate 9, figure 3 , the dorsomedian plate of the type specimen is refigured to show the continuation of sensory canals over part of its surface, their presence having escaped Newberry's attention. No figures have been published of the form described by Cope from the Chemung of Leroy, Pennsylvania, under the name of $\mathrm{C}$. $\mathrm{macromus}$, but it is said to be distinguished from C. occidentalis by its coarser tuberculation.

In plate 1 , figure 9 , is shown a dorsomedian plate of a small Coccostean fish from the Onondaga limestone of Clifton Springs, N. Y., the original of which is preserved in the State Museum at Albany [cat. no. 181]. A small portion of the bone substance is preserved intact on the right-hand side, and shows a coarsely tuberculated ornament. The remainder of the plate is broken away, leaving an impression of the under surface. There is also visible a strong longitudinal keel which extends along the median line, but

× Fürbringer, K. Beiträge zur Morphologie des Skeletes der Dipnoer etc. Semon's Zool. Forschungsreisen in Australien. Jena Denkschr. 1904. 4:493. 
terminates abruptly at some distance in advance of the posterior margin. The latter is continued backward in triangular fashion, but is not produced into a long spine as in $\mathrm{C}$. oc c identa $\mathrm{l}$ is. This unique specimen, which probably belongs to a distinct species, is interesting in view of the horizon from which it was obtained, and on account of the great rarity of Coccosteus remains in this country. It seems inadvisable to propose a new specific title for it, however, until other parts of the skeleton are known.

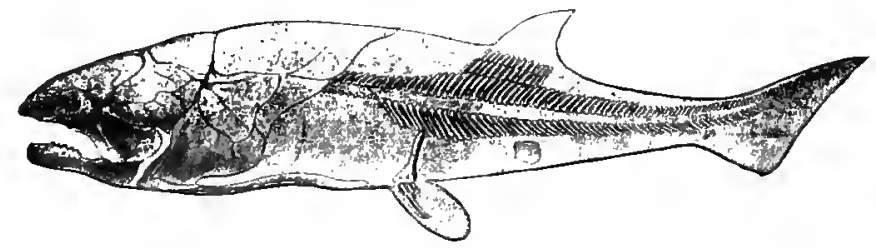

Fig. $2 z$ Coccosteus d e cipiens Agassiz. Lower Old Red sandstone: Scotland. Lateral aspect, restored by Dr A. S. Woudward, partly after Trauuair. $x$ ' 1 . The caudal fin is here conjecturally restored as heterocercal, but more probably it was diphycercal.

\section{Coccosteus macromus Cope}

r 892 Coccosteus macromus E. D. Cope. Am. Soc. Phil. Proc. 30:225

Of this species no other examples are known except those obtained by Professor Cope, whose original description follows:

Fragments of this species are abundant in the Chemung rocks at Leroy [Pa.], and I select as typical of it a pair of supraclavicular and adjacent pieces, which display its characters best. The supraclavicle has lost the condylar articulation. Both extremities display the unsculptured surface, and the usual groove extends obliquely across the sculptured portion at about two fifths the length from one of the extremities. The sculpture consists of obtuse tubercles with delicate radiate-grooved bases, which are usually separated by spaces equal to their own diameters, sometimes by narrower spaces, but never by spaces which are wider. At some points they have a linear arrangement. This sculpture is coarser than in the $C$. a merican us $[i . c$. C. o c c identalis] Newberry [see The Palaeozoic Fishes of North America, by this author], but resembles that of C. d e c i pie ns Agass. of Scotland. From this species the C. $\mathrm{macromus}$ differs in the elongate form of the supraclavicle which is relatively short and wide in the C. decipiens [sec Agassiz, in the Poissons du Vieux Grès Rouge, and Zittel, Handbuch der Paläontologie].

Length of supraclavicle

Width just above condyle

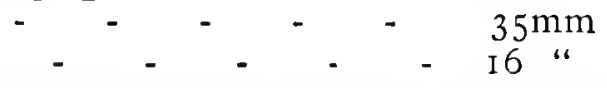

Formation and loc ality. Chemung beds (Chautauquan); Leroy, Pa. 


\section{Genus acarthaspis Newberry}

An imperfectly definable genus of Coccostean fishes, known only by detached plates resembling the antero-ventrolaterals of Phlyctaenaspis.

\section{Acanthaspis armata Newberry}

Plate 2, figure 2

r875 A canthaspis armatus J. S. Nenberry. Geol. Sur. O. Rep't. Pal. v. 2, pt 2, p. 37, pl. 53, fig. I-6

I889 A canthaspis a rmatus $J$. S. Newberry. U S. Geol. Sur. Monogr. 16: $3^{6}$, pl. $3 \mathrm{I}$

I894 Acanthasp is armata R. H. Traquair. Ann. Mag. Nat. Hist. ser. 6, I $4: 37 \mathrm{x}$

I 896 A c a $\mathrm{nth}$ as p is a rmata E. $\|^{r}$. Claypole. Am. Geol. I $7: 354$

The spiniferous plates which are known under this provisional designation have not been found in natural assemblage with other parts of the skeleton of forms accompanying them in the same formation, hence their precise relations are indeterminable. Theoretical associations are for the most part valueless, except as they rest upon strongest possible presumptive evidence; and in the present case sufficient data for comparison is lacking. The superficial ornament somewhat resembles that of Macropetalichthys, but according to all appearances that genus was destitute of dermal body armoring. For the present we are obliged to regard Acanthaspis as a provisional genus, whose relations may be assumed to be in the vicinity of Phlyctaenaspis, and not, as was supposed by Newberry, with any member of the Cephalaspidae.

None of the plates in question that have thus far come to light seem to be preserved in their entirety, but the small specimen shown in plate 2, figure 2, is perhaps as complete as any. The lateral spine is always immovably attached to its supporting plate by an oblique suture, which is more conspicuous in larger examples. The interior of the spinous portion is hollow throughout, and along the line of its attachment with the supporting plate is sometimes to be seen a double row of perforations which communicate with the internal cavity of the spine. 
It is inconceivable that this fixed spinous appendage is any way homologous with the jointed pectoral limbs of Asterolepids. Plates not unlike those of the present species have been described by Traquair from the Lower Devonic of the Eifel district under the name of A. pruemensis. The so called A. decipiens of Smith Woodward, from the Lower Devonic of Sipitzbergen, appears to be of different nature.

Formation and locality. Onondaga limestone; Leroy, N. Y., and equivalent formation of Ohio.

\section{Genus Divichтнтs Newberry}

It is difficult to frame a satisfactory diagnosis of this genus which shall enumerate its principal characters and at the same time enabie one to draw a rigid distinction between its various species and those of Coccosteus. The fact is, the two genera are most intimately related, and though their terminal members are sufficiently well characterized, they are connected by insensible gradations. The typical species of Dinichthys represent unquestionably a later and more advanced stage of specialization than that with which we are familiar in Coccosteus decipiens, for example; but between these extremes lies a host of intermediate forms. Evidence of specialization in forms like D. herzeri, D. ter relli etc. is strikingly apparent in their gigantic size, the head shield measuring nearly a meter across, and their massive and cumbersome armor being unrivaled amongst fishes. As a necessary accompaniment of increase in size, the cranial plates become more intimately fused in the adult, the articulations between head shield and abdominal armor more complicated, and various minor modifications are to be seen in the dentition and arrangement of the body plates. Nevertheless, in spite of hypertrophic enlargement of all the parts, there is everywhere a surprising conformity to the basal type of Coccosteus. It is necessary to insist upon this close correspondence, which has hitherto escaped attention (owing to faulty restorations and other reasons), and possibly even now might be questioned by those who have not actually compared the different parts. 
Adopting for our thesis the obvious fact that Dinichthys and Coccosteus are constructed upon the same general type, we may now take note of such differences as exist between them, other than mere size; and for immediate purpose of comparison it will be convenient to choose D. herzeri, D. terrelli and D. intermedius as representatives of the former, and $\mathrm{C}$. decipiens as representative of the latter genus. First, as to the abdominal armor. Here we observe a perfect correspondence throughout, both as to number, arrangement and general form of the plates [ $f$. text fig. 23]. The dorsomedian of Dinichthys is relatively shorter than that of Coccosteus, more emarginate in front and rounded behind, and its inferior keel is developed in to a stout terminal process. There are not usually traces of sensory canals upon its external surface. In Coccosteus, the anterolateral is bounded in front and below by a distinct plate, the interlateral, which forms the connection between the dorsolateral and ventral portions of the abdominal armor. In Dinichthys, the interlateral does not occur as a distinct plate, but may be represented by the forklike prolongation of the so called "clavicular," the broad upper portion of which corresponds, of course, to the anterolateral. The median ventrals of Coccosteus are always separate: in Dinichthys they are occasionally fused.

Secondly, as to the head shield. Again there is notable correspondence of plate for plate, and in the arrangement of sensory canals. The bones are more intimately fused in Dinichthys than in Coccosteus, and the sutures are less wavy. The median occipital is generally pointed in front [cf. text fig. 23], the pineal plate is lancet-shaped and produced backward so as to come in contact with both the centrals and preorbitals, instead of being inclosed by the latter alone, and the plates forming the sides of the head shield are narrower than in Coccosteus. None of these differences, however, can be considered other than of secondary importance, and their aggregate does not in the least obscure identity of structural plan common to both genera. The imaginary plate interpreted by Newberry ${ }^{2}$ with some

r Newberry. J. S. U. S. Geol. Sur. Monogr. I889. I6:334, pl. 52, fig. 2. 
hesitation as a "parietal" in Dinichthys does not occur, an examination of many well preserved cranial shields by the present writer having determined

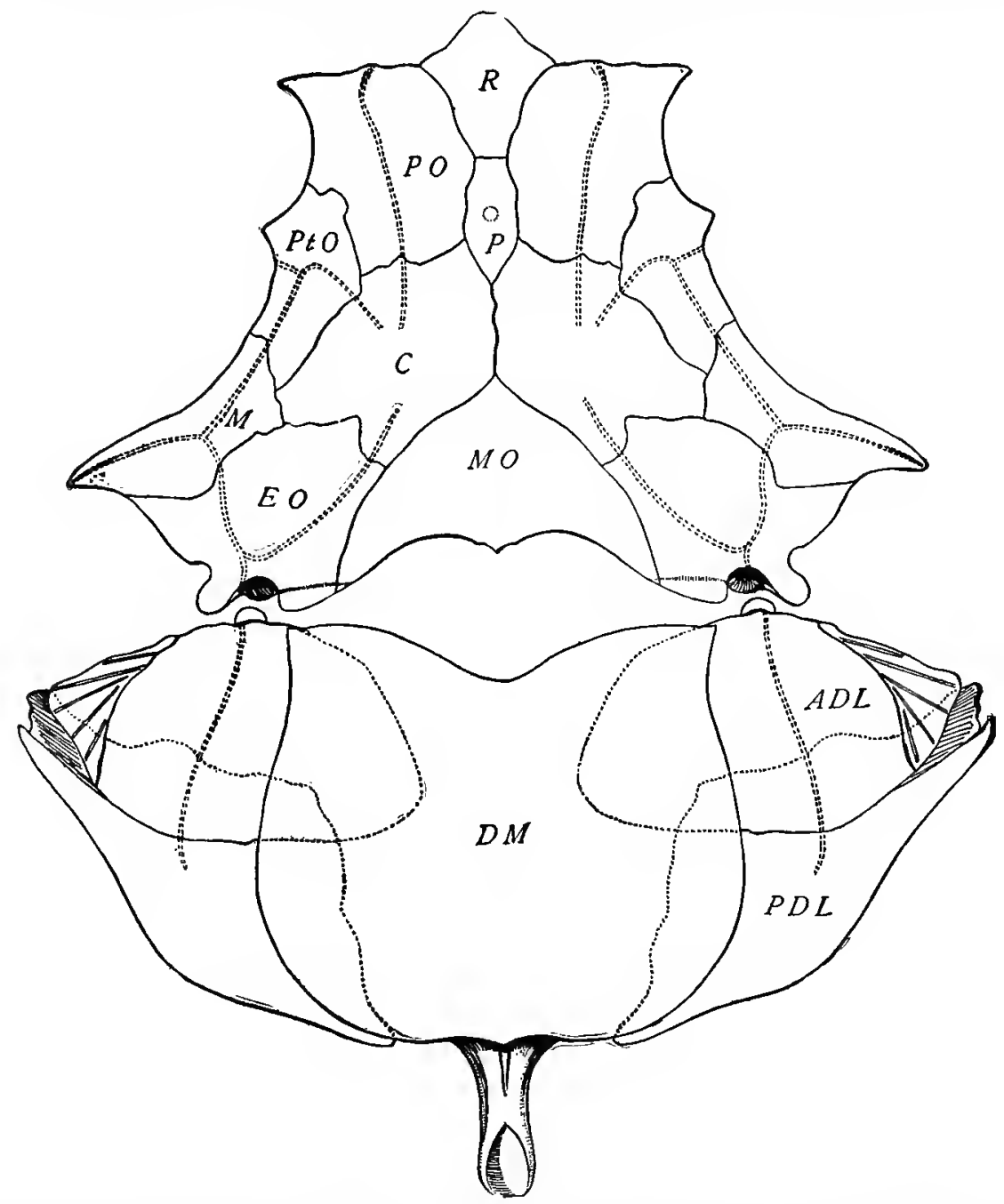

Fig, 23 Dinichthys intermedius Newberry. Cleveland shale: Ohio Restoration of head shield and dorsal armnring of trunk; $x$ I-5. $A D L=$ antero-dorsolateral; $C=$ central; $D M=$ dorsomedian; $E O=$ external occipital; $M=$ marginal ; $M O=$ median occipital ; $P=$ pineal : $P D L=$ postero-dorsolateral; $P O=$ preorbital ; $P t O=$ postorbital; $R=$ rostral, sometimes identified as "nasal" or "mesethmoid." Sensory canals shown by double, overlap by single dotted lines. The markings on the outer (lower) border of the lateral plates indicate the extent of the overlap by the clavicular, which is omitted from this diagram. (From Hussakof, rgos)

this point conclusively. In both genera a sclerotic ring is present, the suborbital plate is distinct, and followed behind by one, or possibly two, 
opercular elements, which have been variously interpreted by different writers.

Finally, and this is the most important test of all, we have to consider the dentition. A serious difficulty in the way of correlating the several parts, and of understanding accounts of earlier writers, is removed the moment we perceive that the suborbital plate has nothing whatever to do with the dentition. Its identification in Coccosteus on the part of some writers as a "superior maxillary" is not only erroneous, but misleading, since it implies the development of a secondary upper jaw amongst Arthrodires, and a secondary upper jaw does not occur. The suborbital is simply a cheek plate, and corresponds to the three nonfused ossicles forming the lower border of the orbit in Neoceratodus. The dental elements of both jaws are precisely alike in Coccosteus and Dinichthys, as regards number, form and arrangement. The whole matter of the dentition can be summed up by saying that Coccosteus and Dinichthys exhibit the same close parallelism with Protopterus and Lepidosiren as is observed between Mylostoma and Neoceratodus. Coccosteus and Dinichthys represent a modification of Dipnoan dentition adapted for cutting, and closely corresponding modifications exist in the modern fauna. Mylostoma and Dinomylostoma adhere to the ancestral type of crushing or triturating dentition, which has been preserved essentially unchanged until the present day amongst the most generalized descendants of the primordial stock.

It will be seen that the foregoing interpretation is at variance with the one recently proposed by Jaekel in his paper of 1902 , to which frequent reference has been made. The dental plates of Coccosteus are identified in that contribution as maxillae and premaxillae, and their arrangement is expressed graphically by means of a restoration, concerning which the author speaks as follows :

Ich bemerke dazu, dass ich dieses Bild durch sorgfältige Präparation einer ganzen Anzahl von Exemplaren erzielt habe, und dass sich dasselbe von dem Traquairschen Entwurf namentlich unterscheidet durch den Nachweis der Maxillen und Praemaxillen, durch die abweichende Lage der Nasenöffnungen und der unteren Rumpfpanzerelemente, den Nachweis des Beckens und den Hinweis auf paarige Extremitäten. 
When it comes to a consideration of the dental elements in Coccosteus, one is somewhat surprised to find that they are compared directly with Lacertilians, much in the same way as Cope compared Macropetalichthys with Stegocephalians. The continuation of the above passage reads as follows :

Ueber die Bezahnung der Kiefertheile habe ich noch keine volle Klarheit, indess scheint mir Folgendes zu rechtfertigen. Die Bezahnungsform scheint durchaus übereinstimmend mit der von Sphenodon. Von den Zahnspitzen des Unterkiefers dürften mindestens die vordersten dem Dentale, die hinteren, mehr einwärts gelegenen vielleicht dem Spleniale zuzurechnen sein. Die Praemaxillen scheinen entsprechend dem Vorderrand des Unterkiefers mit je einer Spitze versehen gewesen zu sein. . . Die Maxillen sind kleine schmale mehrzackige Knochenstücke die dem Innenrand des suborbitalen Astes des beilförmigen Oberkieferstückes eingefügt sind. Palatinà und Transversa habe ich noch nicht finden können vermuthe aber ihre Existenz hinter den genannten Elementen.

We may now give special consideration to the arrangement of dental elements in Dinichthys. In the upper jaw there are always two pairs of dental plates, which are clearly shown to be of dermal origin. It is denied "by Dean that these plates, which are commonly known as "premaxillaries" and "shear teeth," can be homologized with any structures within the mouth of other fishes, hence he proposes to call them by the noncommittal names of "rostro-gnathals" and "orbito-gnathals" respectively, the term "gnathal" being made synonymous with mandible. According to the view adopted in this report, the anterior pair of upper dental plates in Dinichthys is to be interpreted as vomerine, and the posterior as palato-pterygoid, thus recognizing definite homologies between them and the like named structures which are also of dermal origin - in modern Dipnoans. The vomerine pair is situated close to the median line, one on either side of the plate answering in part to the dermal mesethmoid in Neoceratodus, and the tumid basal expansion is received into a slight concavity on the visceral surface of the preorbital. The exposed, or functional portion of the vomerine teeth is cleft so as to form two vertical prongs or "beaks" of unequal length, the

Ueber Coccosteus und die Beurtheilung der Placodermen. Sitzungsber. Ges. Naturforsch. Freunde. ig02. p. 106. 
shorter of which is inwardly placed and is scarcely separated from its fellow of the opposite side.

At least one Dinichthyid individual is known in which the vomerine pair is solidly fused with the supporting bones of the head shield 'The specimen referred to forms part of the collection of Ohio fishes brought together by Dr William Clark and eventually acquired by the British Museum of Natural History. It is catalogued under the number P. 9490, and in the opinion of Dr A. S. Woodward, keeper of the Geological Department, properly belongs to the genus we are now considering. Another interesting specimen having the upper and lower dental elements preserved in situ, is preserved in the same collection under the catalogue number P. 9340. By means of this and similarly preserved material, and also by examining the marks of wear in upper and lower dental plates, one may readily determine the manner in which the dental parts came together when the mouth was closed. The vomerine teeth are seen to have protruded just a trifle in advance of the mandibular beaks, which closed within the angle formed by the prongs of the opposing elements. A few plates of Dinichthyid armor are also known, which have been bitten by creatures of their own kind in such wise as to leave the impress of teeth; and these markings confirm in an unexpected way the observations we have just made concerning the arrangement of jaw parts, besides affording indications of the distance apart of the symphysial beaks. The best illustration that has been offered of the manner in which the upper and lower dentition came together in front will be found in the frontispiece of Dr Bashford Dean's work on Fishes, Living and Fossil. Some novel suggestions concerning the interplay of the jaw parts, which are assumed to have been freely mobile, are contained in Dr L. Hussakof's Studics on the Arthrodira, published in volume IX of the Memoirs of the American Museum of Natural History, 1906.

The vomerine teeth are succeeded almost immediately behind by the cleaverlike palato-pterygoid plates, called by Dean "orbitc-gnathals," but commonly known as "shear teeth," in allusion to their mode of working 
against the trenchant margin of the lower dental plates like the blade of a pair of shears. The manner of their operation remains the same even in those species where the opposing margins are denticulated, a condition which is regarded as more primitive than that with simply sharpened, or beveled edges. Traces of an original denticulation, which once extended along the entire functional margin, are often observed in the form of tubercles, or denticles, whose position is confined in specialized species to the extreme posterior margin of the tooth. It is to be noted that this posterior margin is usually narrower and more rounded than the anterior. Slightly in advance of the middle portion of the tooth, along its superior margin, there is given off from this upper margin a well marked, inwardly curved ascending process or "shoulder," which corresponds without question to the similarly placed process of Ceratodont dental plates. Notwithstanding the large size and evidently great efficiency of the shear teeth, they do not appear to have been rigidly attached to the head shield, but rather to have been held in place by cartilage against the prominent inferior ridge which extends forwards as far as the orbital region from the posterolateral angles, in a direction parallel with the sides of the head shield. Precisely similar conditions are observed in Neoceratodus, where the ridges referred to serve as a support for the upper dental plates, and relieve the strain imposed by the action of the jaws in mastication. It is interesting to note that these ridges along the underside of the head shield in Dinichthys acquire greater solidity in proportion as the dental plates become more massive and powerful.

Finally, attention may be directed to the lower dental plates strictly speaking, the term of "dental plate" being properly limited to the functional, anterior portion of the mandibular arch, with which element it is fused. The relations between the lower dental plate and the supporting ossification, or splenial, and the manner in which it is supposed to have become rotated so as to stand upright in the jaws, are matters that have been sufficiently explained in the general account of Arthrodires [cf. sutpra, p. 95]. In almost all species of Dinichthys, the anterior extremity of 
the mandible is developed into a powerful cutting beak, usually much facetted by wear. The marks of contact with the opposing pair of vomerine elements were attentively examined by Newberry, who concluded that they closed together in the following manner: "The incisorlike teeth of the premaxillaries interlock with and shut over the projecting points of the turned up mandibles, which are received into their concavities." Again, in describing these elements in D. terrelli, he observes: "The inner [= posterior] side is concave and frequently much worn and excavated by the prominent extremity of the mandible, over which it shuts." ${ }^{x}$

Some distance behind the symphysial beak, the functional margin of the lower dental plate rises again into a prominent projection, shorter, however, and less massive than the first, and appearing on the inner aspect as a distinct riblike swelling, nearly vertical, and evidently in the nature of a rudimentary tooth. From this point backward along the functional margin, the lower dental plate is compressed into a thin edge, beveled somewhat on the outer face by contact against the opposing element of the upper jaw. In the majority of species, the margins of both upper and lower dental plates are smooth and bladelike; but a few, including the type, have them denticulated as in Coccosteus. Vestigial remnants of a primitive Ceratodontlike denticulation occur in the lower dental plates along the abrupt downward slope of their posterior margin; that is to say, in a position corresponding to that in which they are seen in the upper.

The line of fusion between the lower dental plate, in the strict sense of the term, and the supporting ossification, which we take to be the splenial, is marked externally by a prominent constriction, starting from a point slightly behind the functional margin, and extending in a curved line downward and forward until reaching the bottom point of the anterior or symphysial margin. Seen from the external aspect, the lower dental plate thus appears to be set off from the slender, elongate shaft of bone which we identify as splenial, by means of a conspicuous shoulder, underneath which there runs a groove for the lodgment of portions of the Meckelian cartilage.

× Newberry, J. S. Ohio Geol. Sur. Rep't. Pal. I875. v. 2, pt 2, p. 5, 29. 
The correctness of our interpretation of the groove in question is clearly established through comparison with Protopterus and Lepidosiren. ${ }^{x}$ Only in one respect is there a marked distinction between the mandibles of Dinichthys and those of Coccosteus; no species of the former genus are known to have denticulations along the symphysial margin. On the other hand, a series of tubercles is sometimes present along the outer face of the vomerine teeth in Dinichthys, and this fact suggests the probability of tubercles or denticles having been present in the lower dental plates as well, at an earlier period in the history of these forms. The differences between Dinichthys and Titanichthys will be considered in the discussion of the latter genus.

\section{Dinichthys halmodeus (Clarke)}

Plate 2, figure 7 ; plate ro, figure $x$ : text figure 24

I 894 Coccosteus (?) halmode us J. M. Clarke. N. Y. State Geol. Rep't I 893, I: 162 , pl. I

I $900 \mathrm{D}$ in ichthys halmodeus C. R. Eastman. Jour. Geol. 8: 34

rgo6 Dinichthys hal modeus L. Hussakof. Am. Mus. Nat. Hist. Mem. 9, p. 140 , text fig. $22 \mathrm{C}, 2_{4} \mathrm{~A}$.

A primitive species of small size, the head shield having a total length of about II cm, and very similar to Coccosteus in the configuration of plates, arrangement of sensory canals, and character of the superficial ornamentation. The suture lines, however, are less undulating than in Coccosteus, the articulation with the abdominal armor is much stronger, the pineal is partly in contact with the centrals, and the dentition is characteristically Dinichthyid, with strongly developed vomerine teeth. The anterior margin of the lower dental plates is developed into a prominent beak, and the superior or functional margin is strongly denticulated; the posterior extremity of the splenial is broad and spatulate. The suborbitals are unusually wide and massive, and the rostral seems to have been laterally expanded in front. The dorsomedian bears the usual inferior keel, its

I Wiedersheim, R. Morphologische Studien. Heft I, p. 55, jl. 2, fig. 3, 8. Jena. 1880; Fürbringer, K. op. cit. p. 481, pl. 39, fig. 28; Bridge, T. W. Morphology of the Skull in Lepidosiren. Zool. Soc. 'Trans. 1898. 14:342, pl. 28, fig. $7,8$. 
terminal process being given off at a slight distance in advance of the posterior margin.

In the minute and in most respects very accurate description given of

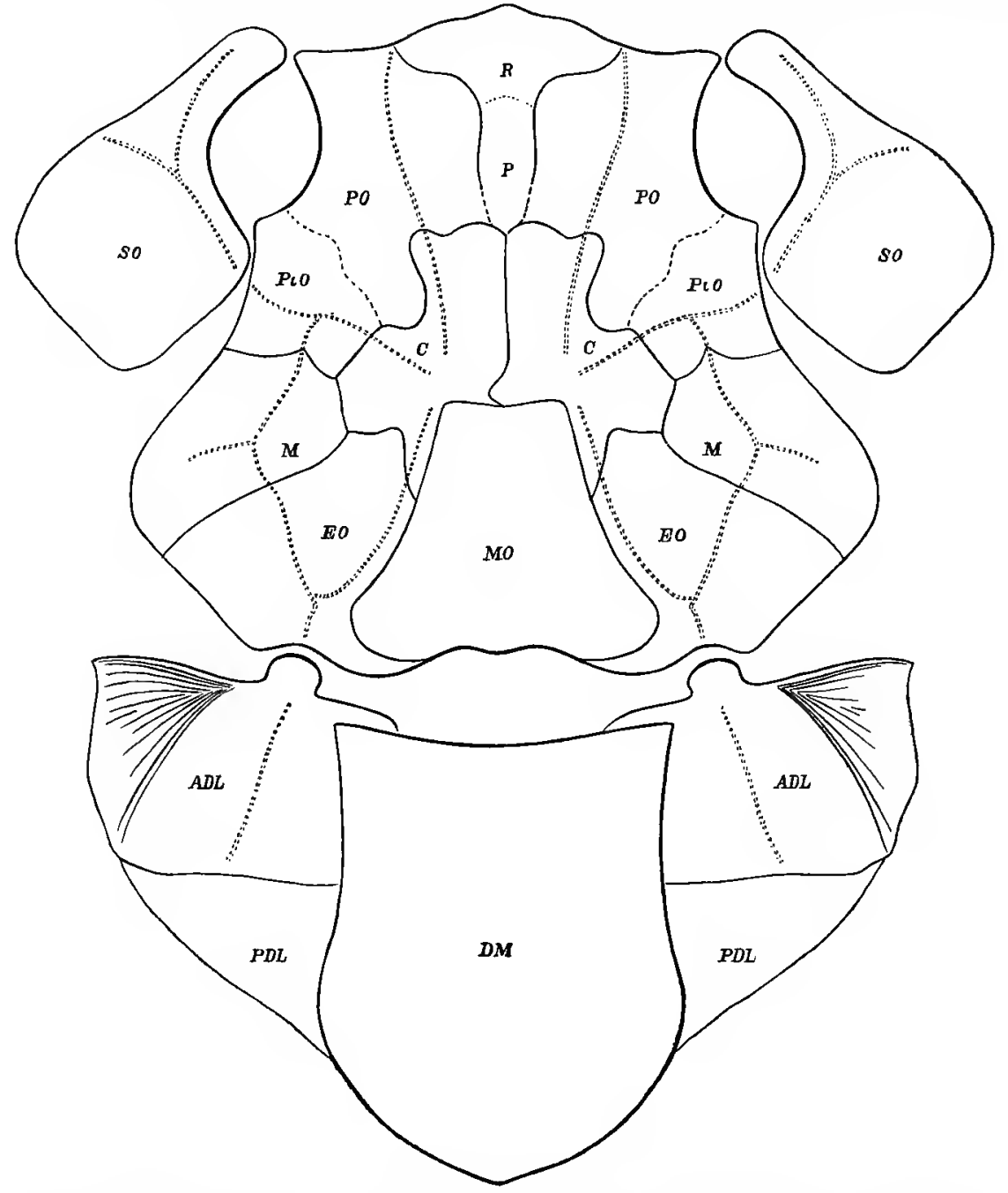

Fig. 24 Dinichthys halmodeus (Clarke). Erian; Livonia Salt Shaft, N. Y. Restoration of head shield and dorsal armoring of trunk. $\times 3 / 3 . A D L=$ antero-dorsolateral ; $C=$ central ; $D M=$ dorsomedian ; $E O=$ external occipital ; $M=$ marginal ; $M O-$ median occipital; $P=$ =pineal : $P D L=$ posterodorsolateral : $R-$ rostral ; $50=$ =suborbital

the type specimen by the original author, it is clearly stated that the dentition presents "an aspect highly similar" to that of Dinichthys, comparisons being made between the present species and D. her $z$ eri, which also has 
the functional margin denticulated. The observation is of sufficient weight, in our opinion, to justify the transfer of this species from Coccosteus, where it was doubtfully placed by Dr Clarke, to Dinichthys. Of special significance from a systematic standpoint are the vomerine teeth, which are described as follows by the same author: "Each is concave on the inner surface, convex externally, and bore a somewhat extended apophysis, which in each case has been broken off. There is no evidence of denticles or a tuberculated surface; the lower edge is, however, rather sharp and would have served a cutting purpose." Amongst other minor peculiarities of the head shield may be mentioned the subquadrate outline of the median occipital, and the strong outward flexure of the preorbital sensory canals characters which one may regard as of specific importance.

Associated with the head shield, and possibly belonging to the same individual, certainly to the same species, is a specimen interpreted by $\mathrm{Dr}$ Clarke with some reservation as a dorsomedian plate, and considered by him to be divided by sutures into three parts. In the explanations of plates, however, it is conceded that "the surface shows no satisfactory evidence of sutures," and after a careful inspection of the original, the present writer is convinced that the plate is normal in all respects, except that the external surface has been somewhat injured. That others may judge of the characters of this plate, an illustration is given of it in plate 2, figure 7. It has a total length of $9 \mathrm{~cm}$, and apparently did not exceed $2 \mathrm{~mm}$ in thickness; the carinal process has been broken away. The locality from which both of these interesting specimens were obtained was the Livonia salt shaft, in Livingston county, New York, at a depth of 828 feet below the surface. They are preserved in the New York State Museum at Albany. Another interesting cranial fragment belonging to the same museum, and from the same horizon as the preceding, is shown in plate so, figure 1. In size, it indicates an individual about one third larger than the type of D. halmodeus, and the tuberculation is relatively coarser, but the form of the median occipital element agrees so closely with that of the latter species, it is difficult to regard this as other than an adult example; 
besides, it is a well ascertained fact that the tubercles increase in size with age. The median occipital has an extreme length of $5.5 \mathrm{~cm}$, and thickness of about $3 \mathrm{~mm}$. The specimen is labeled as having been found "Sept. 9, 185I. in the Goniatite limestone 'at Hendrick's ledge, west of Manlius, N. Y." There is no catalogue number.

Formation and locality. Marcellus division (Erian); New York.

\section{Dinichthys lincolni Claypole}

Plate 7, figures $4^{-6}$

I893 Dinichthys lincolni E. IV. Claypole. Am. Geol. I2:277, text fig. p. 276 I906 Dinichthys lincoln i L. Hussakof. Am. Mus. Nat. Hist. Mem. 9, p. II7, 142

Known only by a single right vomerine tooth of about the size of the corresponding element in D. in te rmedius Newberry, and very similar to it in general form. The external surface, however, not only along the symphysial margin, but also over nearly all of the exposed portion, is covered with enlarged conical tubercles, or even denticles, which are arranged. in more or less regular vertical series. The externolateral process which serves for the attachment of the tooth to the preorbital, is well developed, but distally somewhat compressed.

The unique tooth upon which this species is founded possesses a number of interesting features. In the first place, as already noted by Claypole, it is singular in having the entire outer face strongly tuberculated; and it is noteworthy that the tubercles are most conspicuously developed, so that they become in fact denticles, along the inner or symphysial margin, thus placing the species in close relation with $\mathrm{D}$. her zeri. The dermal origin of the different dental plates in Arthrodires could not be more distinctly indicated than by these vestigial remnants of Uronemuslike tuberculation.

Another point worthy of attention relates to the marks of contact with the lower dental plates, such as are plainly visible on the inner or posterior face of the tooth. It is evident that the larger and outer (ectad) prong has been considerably worn down by use, and its lower extremity blunted;

'The Agoniatite limestone, which in the section referred to lies between the Marcellus and Cardiff shales. 
but on examining its inner aspect, and also that of the secondary (entad) prong, one may determine the exact position occupied by the anterior beak of the mandible when the jaws were closed. Furthermore, the beveling of the inner edge is so regular, and there is such close conformity of all the parts, that it appears practically certain that the teeth were held rigidly in place against the head shield, and incapable of motion either forwardly or laterally. Bashford Dean, however, has expressed the opinion that not only each of the mandibular rami, or "gnathals" as they are termed by him, but the various parts of the upper dentition as well, were capable of a considerable amount of independent motion. At the same time he acknowledges that these conditions are absolutely unparalleled amongst chordates. In cases like this, the improbable is always to be distrusted. Finally it is to be noted that a portion of the tooth is somewhat deformed - whether as the result of accident during life of the creature, or through pressure during the process of fossilization, it is difficult to say - but whatever the cause, it did not operate so as to crush the more slender prong, or rend it asunder.

Formation and locality. "The specimen was found in the Marcellus shale at the foot of Slate Rock fall, near Geneva, Ontario co., N. Y., 25 feet below the basal limestone of the Hamilton group, in October, I89o." The original is now preserved in the New York State Museum at Albany, and bears the catalogue number $\frac{16022}{\mathrm{I}}$.

\section{Dinichthys pustulosus Eastman}

Plate 2, figure 6; plate 5. figure 2, 3 : plate 12 , text figure 25

1897 Dinichthys pustulosus C. R. Eastman. Mus. Comp. Zool. Bul. 31:38, pl. 3, fig. 4

I 898 Dinichthys pustulosus $C$. R. Eastman. Am. Nat. 32:748, text fig. I, 2 I goo Dinichthys pustulosus C. R. Eastman. Jour. Geol. 8: $3^{2}$, text fig. I

Igor Dinichthys pustulosus B. Dean. N. Y. Acad. Sci. Mem. 2: I22

I902 Dinichthys pustulosus $O$. H. St John. Am. Nat. 36:657, text fig. I, 2

rgo6 Dinichthys pustulosus L. Hussakof. Am. Mus. Nat. Hist. Mem. 9; p. I42, text fig. $22 D$

A primitive species somewhat smaller than D. terrelli, generally of about the size of $\mathrm{D}$. intermedius, and distinguished from both by its 
fine tuberculation, wavy suture lines, and more Coccosteuslike aspect. Lower dental plates with a simple trenchant margin, behind which there is an abrupt downward slope beset with rudimentary denticles. Shear teeth with convex functional margin, simply trenchant, and without posterior denticles so far as known. Vomerine teeth resembling those of D. in termedius. Visceral surface of occipital region without prominent ridges, the posterior pit of the median occipital scarcely divided. Pineal plate apparently in contact with centrals, and with inconspicuous foramen.

Of this species, which appears to have been rather abundant and widely distributed in the Mesodevonic of this country, nearly the entire dermal armor is known, and the whole of the dentition. Amongst the primitive characteristics of the form in question may be reckoned its fine, Coccosteuslike tuberculation, sinuous suture lines, remnants of an original denticulation along the sloping posterior margin of the lower dental plates, and the comparatively slight development in the latter of a toothlike projection at no great distance behind the symphysial beaks. At the same time, however, it must be acknowledged that this species marks a considerable advance over typical Coccosteusiike conditions, inasmuch as the functional margin of the dental plates is no longer serrated, the dorsomedian plate has a strongly developed inferior carina and posterior process, being also emarginate in front, and a clavicular occurs of the usual Dinichthyid type.

The occurrence of D. pustulosus in the Black slate of Kentucky, a horizon corresponding approximately to the Genesee of New York State, favers the supposition that it was the immediate progenitor of forms like D. intermedius and D. terrelli of the Cleveland shale, which have retained a similar form of dentition. According to this view, D. her zeri and other species in which the functional margin of the dental plates is denticulated, form a separate series, descended along collateral lines from Coccosteus, and characterized by the persistence of this distinctly Coccosteuslike feature. We should therefore be inclined to look upon D. h a 1 . mode us as standing in the same ancestral relations to the type species of this genus as does D. pustulosus to D. terrelli. It is noteworthy 
that D. pustulosus does not occur in the rocks of New York State, nor, so far as known, in any district eastward of Kentucky, until very late in the Devonic (Oneonta beds); whereas in the Mississippi valley region it is tolerably abundant throughout the Mesodevonic. Its advent, then, in the Hamilton limestone of the central western states, is probably to be explained through immigration by way of Manitoba and Canada from Eurcpe.

The arrangement of dermal plates in the head shield of this species is shown in the accompanying text figure 25 , and adjoining it is placed, for
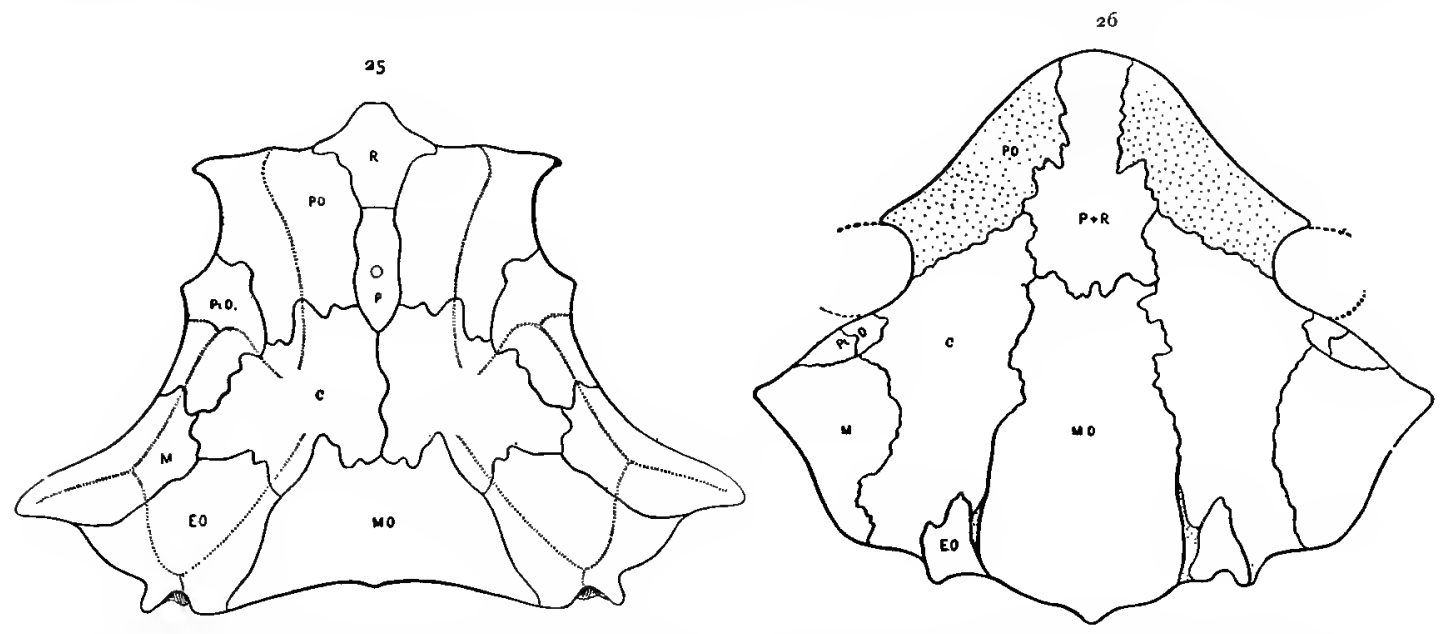

Fig. ${ }_{25}$ Dinichthys pustulosus Eastm. Middle Devonic; Iowa. Restoration of the head shield, dorsal aspect, $x 1 / 4$. $C=$ central $; E O=$ external occipital $M=$ marginal $M O=$ median occipital $P=$ pineal; $P O=$ preorbital ; $P t O=$ postor bital; $R=$ rostral, sometimes identified as tasal or mesethmoid. Sensory canals represented by double dotted lines.

Fig. 26 Neoceratodus forsteri (Kreft). Dorsal aspect of cranial roof, drawn as if fiattened out to same extent as in Dinichthys. Cartilaginous portions dotted, and dermal plates lettered to correspond with those of Arthrodires. The undivided, anterior median plate is commonly termed mesethmoid. $x^{1 / 2}$

sake of comparison, one showing the cranial roof of Neoceratodus. Making proper allowance for the fact that the preorbital plates remain cartilaginous in the recent form, and that the anterior median element ("dermal mesethmoid") is undivided, as it is also in Macropetalichthys, the correspondence in pattern will be sufficiently obvious. The significance of these resemblances can hardly fail to be appreciated, after attention has once been fixed upon them, and they are considered in connection with other points of agreement throughout the entire skeleton. We need not dwell upon these matters further here than to say that all available evidence goes to show 
that the Arthrodiran skull was constructed upon essentially the same model as in Neoceratodus; and the latter, accordingly, furnishes a most valuable criterion for interpreting structural details of the former.

Formation and locality. The remains of this species occur abundantly in the Hydraulic limestone of Milwaukee, Wis., and are not uncommon in the Mesodevonic limestone of Iowa and Illinois. Characteristic fragments have been found in the Black slate (- New Albany, equivalent to the Genesee) near Lexington, Ky.; and portions of the dentition, including more than one well preserved mandible, have been obtained from the Oneonta beds (Senecan) near Delphi and Oxford, N. Y.

\section{Dinichthys newberryi Clarke}

Plate 6, figure 2

I885 Dinichthys newberryi J. M. Clarke. U. S. Geol. Sur. Bul. I6, p. I7, pl. I, fig. I

I889 Dinicht hys new berry i f. S. Newberry. U. S. Geol. Sur. Monogr. I6: I53

I897 Dinichthys newberryi $C$. R. Eastman. Mus. Comp. Zool. Bul. 3r: 3 , pl. I, fig 2

r 906 D inichthys new berryi L. Hussakaf. Am. Mus. Nat. Hist. Mem. 9, p. I45

Mandibles attaining a total length of $28 \mathrm{r} / 3 \mathrm{~cm}$ in the type specimen, with very prominent anterior beak, simple trenchant margin, and closely resembling that of D. pustulosus in general outline. There are, however, no denticulations or tubercles along the downward slope immediately behind the cutting margin, and the other plates associated with the type specimen have a smooth external surface.

A single dorsomedian plate from the same horizon as the type, and considered by Dr Clarke to be specifically identical with it, is thus described by him :

In the same Styliola layer as it outcrops on the east side of Canandaigua lake, near Genundewah, 6 miles from the Bristol locality, I had earlier discovered a dorsomedian plate belonging presumably to the same species. Its dimensions are as follows: length, I $21 / 2 \mathrm{~cm}$ (broken); width anteriorly, $\mathrm{s} 33 / 4 \mathrm{~cm}$; hight of carinal process, $5 \mathrm{~cm}$. . . . The posterior edge of this plate in D. newberryi is broken and has apparently lost 3 or 4 $\mathrm{cm}$ from its length. The smallness of the bones of D. newberryi does 
not indicate immature growth of an individual of either of the other species (i. e. D. terrelli or D. herzeri). The discovery in outcrops of the same horizon, in localities separated by a distance of several miles, of bones of different individuals, all of which seem to agree with one another in their relative proportions, is at least presumptive evidence that these individuals had attained maturity and that the size of the bones given above is that of normal full growth.

The entire ventral armor of a small Dinichthyid, doubtfully referred to this species, and also a pair of mandibles preserved on a single slab, were obtained some years ago by Mr F. K. Mixer from the Black Portage (Rhinestreet) shale at Sturgeon Point, on the shore of Lake Erie near Buffalo. The originals, which have been already described by the present writer, are now preserved in the collection of the Buffalo Society of Natural Sciences.

Formation and locality. Typically from the Styliola layer (Genundewa limestone) of the Genesee shale (Senecan); vicinity of Bristol Center and Canandaigua lake, New York. Possibly also from the Portage beds near Buffalo, New York.

Dinichthys ringuebergi Newberry

188+ Dinichthys minor E. N. S. Ringucberg (errorc). Am. Jour. Sci. [3], $27: 476$, text fig. I, 2

I889 Dinichthys ringuebergi $/$. S. Newberry. U. S. Geol. Sur. Monogr. I6: 60

1897 D in ichthys ringuebergi C. R. Eastman. Mus. Comp. Zool. Bul. 3 I: 40

An imperfectly definable species, founded upon a detached dorsomedian plate having a total length of $16 \mathrm{~cm}$, exclusive of the well developed carinal process. The external surface is described as having a "fine grained rugose appearance" [= finely tuberculate?] and the anterior border is less emarginate than in most species. The type specimen is preserved in the private collection of its first describer, $\mathrm{Mr}$ E. N. S. Ringueberg, of Lockport, N.Y. A second specimen, presumably of identical nature with the type, and from the same horizon and locality, was obtained by $\mathrm{Mr} \mathrm{F}$. K. Mixer a few years ago, and is now preserved in the collection of the Buffalo Society of Natural Sciences.

Formation and locality. Black Portage (Rhinestreet) shale; Sturgeon Point, near Buffalo, N. Y. 
Dinichthys dolichocephalus sp. nov.

Plate 5, figure $\mathrm{I}$

The remains which we propose to describe under this title leave much to be desired in the way of preservation, hence it is impossible to gain more than a superficial idea of the peculiarities presented by the new form. Inasmuch, however, as a number of plates, including the head shield and mandibles, are here found in natural association, and as we have evidently to deal with a form partaking of the characters of both Dinichthys and Coccosteus, some notice of the material seems desirable. Taken in connection with $\mathrm{D}$. hal $1 \mathrm{~m}$ od e u s, from the Marcellus stage, the present species will at least serve to emphasize two facts with which paleichthyologists seem to be unfamiliar. The first of these is that to which we have already called attention, namely, as to the close relations between Dinichthys and Coccosteus; and the second is that, little by little, we are becoming cognizant of a surprising variety of Coccosteuslike forms in the Middle and Upper Devonic, by means of which it may in time be possible to trace the successive stages of evolution leading up from primitive Arthrodires to the gigantic creatures which constitute one of the most remarkable features of late Devonic fish life.

Naturally one turns first of all to the dentition to determine whether the characters approach those of Dinichthys or Coccosteus, and after that one considers the cranial pattern, sensory canals, and arrangement of body plates. On the evidence furnished by the mandibles, which are the only portions of the dentition preserved, one is led to decide unreservedly in favor of an association with Dinichthys; on the evidence of the head shield, and all of the body plates excepting the clavicular, the decision would be in favor of Coccosteus. We are obliged, therefore, to recognize the transitional nature of the species here represented, and as insufficient characters are offered for the erection of a new genus, it may be provisionally assigned to Dinichthys.

The mandibular rami are unusually long and slender, their total length 
being $4.6 \mathrm{~cm}$, and the anterior beak is separated by a considerable interval from the serrated functional margin. The latter terminates posteriorly in a sharp declivity, and this portion of the dental plate is differentiated after the usual manner in Dinichthys. At least eight fine serrations are to be counted along the oral border, quite uniformly spaced.

The head shield is chiefly remarkable for its relative length as compared with the abdominal armor, and for its extreme narrowness anteriorly. The possibility is not excluded, however, that the sinus back of the orbits, although symmetrically developed on both sides in the present condition of the specimen, may be due in part to accidental preservation; but if normal, a resemblance is to be noted to the configuration of the head shield in T it a nichthys brevis, as represented in Claypole's restoration of the latter form. ${ }^{2}$ The suture lines are less undulating than those of Coccosteus, the agreement being rather with Dinichthys in this respect. The rostral plate has become dislocated from attachment with the head shield, but is preserved intact on another portion of the slab (between the right anterodorsolateral and mandible). Its outline is represented by dotted lines in the figure, as if it were replaced in natural position, but it is impossible to assign definite limits to the pineal and contiguous plates. The median occipital develops a small process in the median line posteriorly, as in some species of Dinichthys. The dorsomedian plate is decidedly Coccosteuslike, and but little emarginate in front, a character which it shares in common with $\mathrm{D}$. halmodeus. The antero-dorsolaterals have strong articular condyles, and much extended anterior margins. The postero-dorsolaterals are slender, triangular plates, not unlike those of Dinichthys. A pair of imperfectly preserved bones, which may possibly be the claviculars, occur to one side of the last mentioned plates; whatever their true nature, they have at least a form not unlike the clavicular of Titanichthys. The ventromedian is narrow and elongate, the postero-ventrolaterals very similar to those of Coccosteus.

In order to provide data which shall serve for a comparison of parts

'Am. Geol. I 896. v. I7, pl. го. 
between this and other species, the following table of measurements is given:

\begin{tabular}{|c|c|c|c|c|c|}
\hline Length of head shield along medi & line & & - & & $8.3 \mathrm{~cm}$ \\
\hline Maximum width of head shield & & & & & $8 \cdot 3$ \\
\hline Length of dorsomedian - & - & & - & & $5 \cdot 2$ \\
\hline Maximum width of dorsomedian & - & & & & $4 \cdot 4$ \\
\hline Maximum width of antero-dorsola & ral . & & & & 4.0 \\
\hline Length of postero-dorsolateral & - & & & & 3.8 \\
\hline Total length of mandible & & & & & 4.6 \\
\hline
\end{tabular}

Formation and locality. The unique specimen answering to the above description was obtained by $\mathrm{Mr}$ F. K. Mixer from the black Rhinestreet shale (Portage) at Sturgeon Point, on the south shore of Lake Erie, near Buffalo, N. Y. It is now preserved in the collection of the Buffalo Society of Natural Sciences, and the writer is indebted to $\mathrm{Mr}$ Mixer for the privilege of its description.

\section{Dinichthys tuberculatus Newberry}

I 888 D in ichthys tuberculatus $J$. S. Newberry. N. Y. Acad. Sci. Trans. $7: 179$

I 889 D in ic h thys tuberculat us $J$. $S$. Newberry. U. S. Geol. Sur. Monogr. I6: $9^{8}$, pl. $3^{2}$, fig. 3

I893 Dinichthys tuberculatus E. W. Claypole. Am. Geol. r2:277

I 897 D in ichthys tuberculatus C. R. Eastman. Mus. Comp. Zool. Bul. $31: 3^{8}$

I 899 D in ichthys tuberculatus C. R. Eastman. N. Y. State Geol. I th An. Rep't, p. 3 I 8

An imperfectly definable species, known only by detached plates which are remarkable for their relatively great thickness, and coarsely tuberculate style of ornamentation. The known portions of the abdominal armor indi. cate a species rather less than one half the size of $D$. in termedius. In the present state of our knowledge, there are no reasons other than differ. ence in geological horizon to prevent assigning to this species certain heavy and coarsely tuberculated Dinichthyid plates found in the Middle and Upper Devonic of Wisconsin and Iowa; neither is it possible, except for difference in geological age, to recognize a distinction between the plates 
known under this name and the so called D. precursor Newberry, from the Corniferous limestone of Ohio. The typical locality for D. t u ber c ulatus is in the Chemung conglomerate of Warren, $\mathrm{Pa}$., but according to Newberry, the same form occurs also in the Upper Devonic of Belgium.

Formation and locality. Chemung beds (Chautauquan); Warren, Pa. Also, according to Newberry, in the Psammites de Condroz, near Liège, Belgium. Either this or a very similar species is also represented in the Middle and Upper Devonic of Ohio, Wisconsin and Iowa.

Dinichthys curtus Newberry
I 888 Din ic intly s curtus f. S. Newberry. N. Y. Acad. Sci. Trans. 7: i 79
I889 J) in ichthys curtus J. S. Newbery. U. S. Geol. Sur. Monogr. 16:156, pl. 48 , fig. 3 ; pl. 53 , fig. $\mathbf{I}-t$
I893 Dinichthys curtus E. HF. Claypole. O. Geol. Sur. Rep't, 7:606
I893 Dinichthy s curtus A. A. Wright. O. Geol. Sur. Rep't, 7:623
I 900 D in ichthys curtus C.R. Eastman. Jour. Geol. 8: 33
I 905 Din ic ht hys curtus L. Hussakof. Am. Mus. Nat. Hist. Bul. 2 I:409, pl. I5, fig. I; pl. i 6
1906 Dinichthys curtus L. Hussakof. Am. Mus. Nat. Hist. Mem. 9; p. ir 2, text fig. 5, pl. I 2

Newberry's description of this species is as follows:

Fishes of moderate or small size; head a nearly equilateral triangle, measuring about a foot on a side: cranium, maxillary and mandible similar in character to those of $\mathrm{Dinichthys}$ intermedius, but only half to two thirds as large, and the mandible bears two subordinate prominences back of the turned up toothlike extremity; also the posterior end of the cutting edge is set with two or three unequal denticles in place of the series of even, lancetlike points in the same position on the mandible of $\mathrm{D}$. intermedius. The anterior ventrolateral plate is scimiter-shaped, 8 inches long by $21 / 2$ inches wide, being relatively narrower than the corresponding bone in any other species known.

Occurring typically in the Cleveland shale of Ohio, this species is also reported by Newberry from the Chemung of Pennsylvania, although no precise indications as to locality are given. Investigation shows that detached plates of a species fully as large as D. curtus, possibly even larger, occur in the Chemung of Warren county, Pennsylvania, but the pres- 
ent writer is unacquainted with any evidence which will enable one to state positively that the species is identical with any of the Ohio forms. It is to be hoped that more characteristic remains from the eastern region may yet be brought to light. Quite recently the Ohio material has been subjected to a renewed examination by Mr L. Hussakof, of the American Museum at New York, who gives a restoration of the ventral armoring [1905, p. 4r2], and discusses the arrangement of jaw parts (1906, p. 112).

Formation and locality. Cleveland shale (Upper Devonic); Ohio. Presumably also in the Chemung of Pennsylvania.

\section{Dinichthys sp. ind.}

Amongst the series of fish remains collected by Professor Charles S. Prosser from the Chemung of Delaware county, New York, and from the Catskill beds near Palenville, occur fragments of small Dinichthyids agreeing in size with the plates of D. tuberculatus, but too poorly preserved for satisfactory determination. Figures are given of two of these plates in an appendix to Professor Prosser's paper on the "Hamilton and Chemung Series of Central and Eastern New York," published in the I7th Annual Report of the New Fork State Geologist for the year 1897. In addition, there is preserved in the State Museum at Albany one very perfect example of the postero-dorsolateral plate belonging to an unknown species of Dinichthys, from the Chemung of Franklin, in Delaware county. It has a total length of about $30 \mathrm{~cm}$, is finely tuberculated, and shows impressions of sensory canals on the external surface [see pl 6, fig. I]. The same museum also possesses an imperfect head shield, preserved so as to show the visceral aspect, of a small Dinichthyid from the Oneonta sandstone of Oxford, N. Y., its general appearance being suggestive of D. pustulosus, but having a width of only $9 \mathrm{~cm}$ across the posterior border. Other obscure fragments are known from the lower Genesee of Eighteen Mile creek, near Buffalo, and from Hamilton rocks at Haight's Quarry, Cazenovia, N. Y. The Black slate of Kentucky, a horizon just above the Hamilton, also yields a considerable number of fragments. 


\section{Genus TITANICHTHYS Newberry}

Plates of head and trunk resembling those of Dinichthys, but relatively thinner, and more laterally expanded. Pineal plate elliptical, broader than long, in contact with the centrals, and pierced by one or two foramina, the latter sometimes capped by a small bony operculum. Lower dental plates long and slender, without denticulations, grooved in the anterior portion of the oral margin as if for a horny sheath, and somewhat turned upwards at the symphysis. Outer (free) portion of clavicular developed as a stout arm, rounded or semicylindrical in cross-section.

The remarkable fishes comprised by this genus represent the ultimate stage of specialization attained by Dinichthyids. Unable to maintain an existence except under peculiarly favorable conditions - their gigantic size, unwieldy organization and weak dentition presupposing an estuarine habitat and abundant food supply - they survived for a relatively short period, and within a limited area. Their remains are confined, so far as known, to the Upper Devonic of Ohio. Forerunners of the genus, however, make their appearance as early as the Ulsterian, and fragmentary plates very suggestive of Titanichthys occur in the Hamilton limestone of Milwaukee, Wis.

The arrangement of cranial plates conforms closely to the pattern of typical Coccosteans. The bone substance, however, is much thinner, the sutures more intimately fused, and all of the plates are relatively broader. The long axis of the pineal, too, is transverse instead of longitudinal, as in Dinichthys and Coccosteus. The enormous width and fiatness of the cranial and abdominal armor plainly indicate a depressed, raylike form of body, probably correlated with bottom-feeding and generally sluggish habits. Certainly the degenerate character of the dentition does not permit us to look upon these creatures as very formidable competitors of Dinichthys and the much more agile Cladoselache.

Interesting features are displayed by the abdominal armor. The mode of articulation between the head shield and antero-dorsolateral plates is less complicated than in Dinichthys, the condyle and socket of the latter form being replaced by an elongated flange and groove, which probably admitted 
of but slight movement between the parts. In the type species at least, the antero- and postero-dorsolateral plates are completely fused, and are overlapped to a relatively greater extent by the dorsomedian than in Dinichthys. Particular attention is claimed by the last named plate, for the reason that its relations have not been clearly understood. It would appear that our only knowledge of the dorsomedian in Titanichthys is confined to a single specimen, identified by Newberry as belonging to T. clarki, but wrongly referred by him to the "underside of the body or head." $x$ A figure of it is

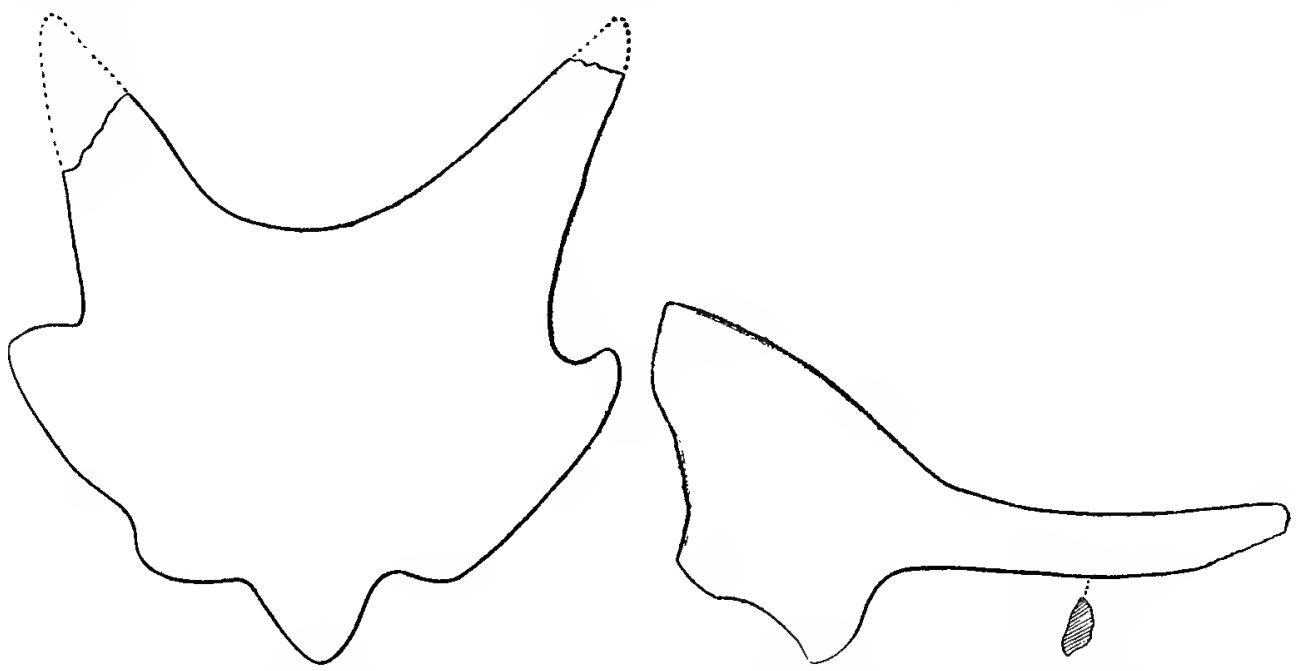

Fig. 27 Dorsomedian plate of Titanichthys clarki Newb, from the Cleveland shale of Ohio. Original in American Museum. $x$ 1-Ir

Fig. 28 Clavicular of Titanichthys clarki Newb, from the Cleveland shale of Ohio. Original in American Museum. given, with the posterior margin uppermost, in plate 3 , figure $\mathrm{I}$ of $\mathrm{New}$ berry's monograph, and its outlines are reproduced in the accompanying text figure 27. The original is now preserved in the Americar Museum of Natural History in New York, after having remained for some time inaccessible in the collections of Columbia University. Newberry's failure to recognize this plate as a dorsomedian is probably to be explained by the fact that its visceral aspect is embedded in the matrix, thus concealing the characteristic longitudinal keel. That the latter was present, how-

I U. S. Geol. Sur. Monogr. 1889. 16: 135 . 
ever, is shown by a convenient fracture, although there is no evidence that it terminated in a distinct process, as in Dinichthys. Mylostoma, and other genera. Measurements show that the extreme length and width of this plate are very nearly equal, the distance between the anterolateral extremities amounting to $70 \mathrm{~cm}$. In an earlier restoration of $\mathrm{T}$. agassizi by

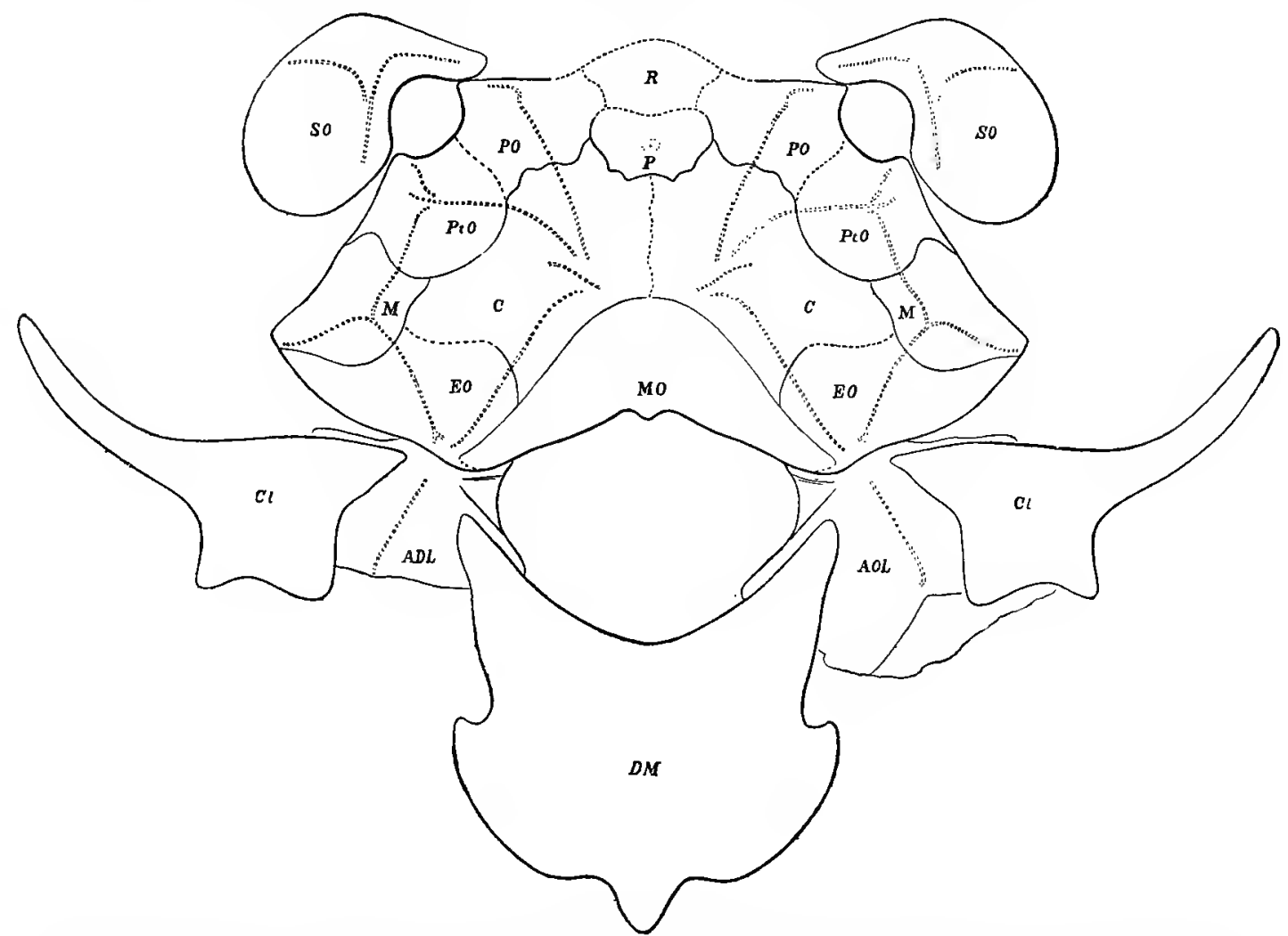

Fig, 29 Titanichthys agassizi Newb. Restoration of head shield and dorsal armoring of trunk, x r-r3. ADL=anterodorsolateral, fused with the postero-dorsolateral ; $C$-central; $D N=$ dorsomedian restored after the outline of $\mathrm{T}^{2}$, clarki; $E O=$ external occipital ; $I T=$ marginal ; $M O=$ median occipital ; $P$ =pineal ; $R=$ position of rostral ; $S O=$ suborbital

the present writer, ${ }^{1}$ the dorsomedian is shown as being partly overlapped by the adjacent plates on either side. This is now believed to be erroneous, the relations of overlap are as in Dinichthys, and the idea that a carinal process was present was suggested by a photograph of a plate purporting to belong to $\mathrm{T}$. clarki, but which, upon examination of the original,

I Am. Nat. I $898 . \quad 32: 763$, fig. 4. 
turns out to have been a large dorsomedian of Dinichthys. The error to which we have called attention is corrected in the new restoration given herewith.

We come now to speak of the clavicular, a plate which has been curiously misinterpreted both in this genus and in Dinichthys. The fragmentary example figured by Newberry in plate 3 , figure 3 of his Monograph on Palaeozoic Fishes under the name of "coracoid (?)," gives no adequate conception of what the plate was like. We accordingly present an outline drawing and section [text fig. 28] of a nearly perfect clavicular of T. cla rki, the original of which belongs to the American Museum of Natural History; and this element is also shown in its natural position, overlapping the antero-dorsolaterals, in the restoration of $\mathrm{T}$. a g a s s izi given in text figure 29. It will be seen from these figures that the external or distal portion of the clavicular is very different from the corresponding portion in Dinichthys, being developed as a stout, slightly curved arm, semicylindrical in crosssection, and not dividing into two branches, nor provided with the peculiar "knuckle joint" described by Claypole in a large specimen of Dinichthys. ${ }^{x}$ The total length of the figured example, measured in a straight line, is $65 \mathrm{~cm}$, and it is evident that the rodlike projection must have extended almost, if not entirely free from the body armor on either side. What function it subserved is difficult to imagine, but as likely a conjecture as any is that it furnished a support for the branchial apparatus and attachment for the tissues connected with the lower jaw. It is impossible to suppose that plates of such thickness as the clavicular - in the distal process it amounts to upwards of $5 \mathrm{~cm}$ - could have been flattened out horizontally by mechanical agencies during fossilization; 'hence, as this bone continues the plane of the head shield and body armor, we are compelled to assign to Titanichthys a depressed form of body, having in the type species the truly enormous expanse from side to side of over 1.5 meters.

Nothing is known of the ventral armor of Titanichthys, unless we are permitted to assign to this genus certain large, thin plates of lanceolate

I Ohio Geol. Sur. Rep't. 1893, 7:6 го, pl. 38, fig. I; pl. 39, fig. I. 
outline, which have been found as yet only in the detached condition, but evidently represent the median ventrals of some large member of the family. One such, having a length of $29 \mathrm{~cm}$, and maximum width of $12.5 \mathrm{~cm}$, has been figured by the present writer in the bulletin of Museum of Comparative Zoology [3 I:26, pl. 5, fig. I]. It is abruptly truncated in front, and bears traces of overlap by contiguous plates; accordingly if this plate is rightly interpreted as belonging to Titanichthys, there is excellent reason to suppose that the ventral armor consisted of the same number of plates as in Dinichthys.

\section{Genus Protitanichthys nobis}

Primitive Coccosteans of small size, displaying composite characters of later forms. Arrangement of cranial plates in general resembling that of Coccosteus, the centrals meeting in a sinuous longitudinal suture and not in contact with the pineal; the latter is subellipitical in outline, its long axis directed transversely, and pierced by a relatively large pineal foramen; rostral plate also very broad. External surface finely tuberculated; lateral margin of head shield apparently not much widened posteriorly; sensory canals distinct [dentition unknown].

\section{Protitanichthys fossatus sp. nov.}

Plate ${ }^{2}$, figure 2 ; text figure $3^{\circ}$

The unique specimen which is here made the type of a new genus and species is of interest in two respects; first, on account of its geological antiquity, and in the second place, because it displays synthetic characters. In the majority of its features, a close approximation is to be observed to Coccosteus, and to the more primitive species of Dinichthys, as for example, D. halmodeus. First of all, there is to be noted its small size, correlated with finely tuberculate ornament of the external surface; secondly, the sinuous suture line between the pair of central plates; and thirdly, the exclusion of the pineal from contact with the latter pair. The form of the head shield, too, although this can only be determined approximately, appears to have been long and narrow, without much lateral expansion at the posterior border. One striking peculiarity, however, distinguishes it 
from all species of Coccosteus and Dinichthys, and points to ancestral relationships with Titanichthys, in recognition of which we have given it the generic name. Indeed, no other course is open to us than to attach significance to a character which is common to the two genera under comparison (Titanichthys and Protitanichthys), but occurs not elsewhere amongst members of the same family. We refer to the large size and transverse elongation of the pineal plate, which, according to our view, indicate an initial modification along the line of descent culminating in Titanichthys. As yet our acquaintance with intermediate forms connecting the archetype and extreme limits of specialization is very inadequate. But when we take into consideration the long geological interval separating the two genera in point of time, it is scarcely risking too much to claim this small composite form as a possible forerunner of the Upper Devonic Titanichthys.

The head shield, itself imperfectly preserved, is unaccompanied by any other bones of the skeleton. Although, as a rule, little dependence is to be placed upon theoretical association of parts, the question may properly be raised whether there are any other Coccostean remains occurring in the same horizon which correspond in general proportions and superficial ornament to the head shield under discussion. Attention rests immediately upon two forms: the lower dental plate described as Liognathus spatulatus, and the dorsomedian plate known as Coccosteus occidentalis [ante, p. 1 I5]. The possibility is not remote that all three of these detached parts which have received separate names may actually belong to a single species; in default of proof, however, we have no other procedure than to maintain each provisionally as an independent species, or even genus. At the same time it may not be unworthy of comment that the peculiar spiniform prolongation observed in Coccosteus occiden$\mathrm{t}$ a $1 \mathrm{is}$ reappears in an abbreviated form in the triangular termination of the corresponding plate in Titanichthys. Such a coincidence certainly suggests the idea of an inherited characteristic, and confirms us in the belief that prototypes of the most highly specialized Coccosteans are to be sought as early as the Ulsterian stage in this country. 
The actual condition of the type specimen may be seen from the photograph reproduced in plate $\mathrm{I} 0$, figure 2 ; in addition, an outline restoration is here offered, which it is hoped will be of service in comparing the arrangement of cranial plates and sensory canals, as far as these are discernible, with other Coccosteans. The specific title has reference to the conspicuous pineal foramen, placed slightly posterior to the middle of the plate. Two

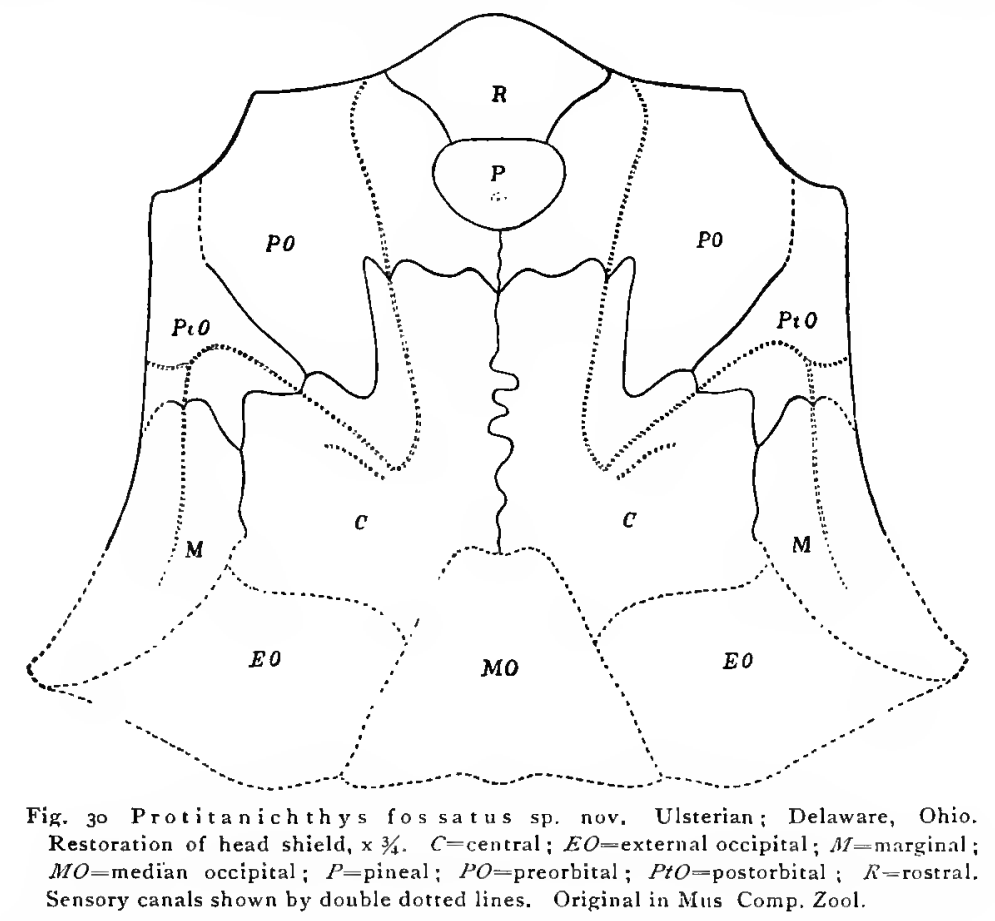

other prominent fossae, corresponding to those in Dinichthys, occur in line with the pineal on the underside of the preorbitals, and these appear to have been bounded by a low transverse ridge in front. Whether or not vomerine teeth were attached in this vicinity can not at present be determined. Analogy, our only guide, would lead us to expect that they had been.

Formation and locality. Delaware limestone (Ulsterian); Delaware, O. Holotype preserved in the Museum of Comparative Zoology at Cambridge, Mass. 


\section{Genus gLyptasprs Newberry}

A provisional genus including Arthrodires of large or even gigantic size, known only by plates of the abdominal armor. Ornamentation consisting of fine stellate tubercles, closely arranged and often becoming confluent in irregular or vermiculating ridges. Overlapping margins of plates broad, beveled to a thin edge, and sometimes striated.

Glyptaspis verrucosa Newberry

I 889 Grlyptaspis verrucosus $J$. S. Newbery. U. S. Geol. Sur. Monogr. I6: 158 , pl. I3, fig. I, 2

Under this name several large plates with strongly beveled edges, and with central portion displaying peculiar ornamentation, have been described by Newberry from the Cleveland shale of Ohio. One of the two plates figured by this author is identifiable as the anterior, the other as the posterior ventromedian, both represented in inverted position. The larger of these, as compared with the corresponding element amongst other forms, indicates a creature fully equaling Titanichthys in size. Of the head shield, and other portions of the armor aside from the ventromedian plates, nothing is at present known, nor has the species been recognized with certainty beyond the confines of the Cleveland shale of Ohio.

Glyptaspis abbreviata sp. nov.

Plate ${ }_{3}$

A few fragmentary plates are preserved in different collections from the Black slate of Kentucky (Genesee) and Portage shale of western New York, which display the vermiculating type of ornamentation peculiar to Glyptaspis, but until recently there has been insufficient material for framing a satisfactory diagnosis of the species represented. The relatively smaller size of the plates, their fineness of ornamentation, and difference in geological horizon lead one to suspect that another than the type species was present during the earlier part of the Upper Devonic, and this inference would seem to be borne out by a recent fortunate discovery, which we owe to Dr J. M. Clarke. 
In plate $\mathrm{I} 3$ is shown an exceptionally perfect abdominal plate identi. fiable as the right antero-ventrolateral of a form closely resembling the type specics of Glyptaspis, but distinguished by its more delicate ornamentation, and by a very marked difference in the proportions of length and breadth. As indicated by the trivial title, the plate here named G. abbreviata is very much foreshortened in an anteroposterior direction, more so than in any other genus of Arthrodires with the possible exception of Trachosteus. The general outline is subtriangular, the total length being but I $5 \mathrm{~cm}$, and width $16 \mathrm{~cm}$. Although actual specimens are wanting of the corresponding plate in G. ver rucosa, we are able to form a tolerably accurate concept of its appearance and general proportions, by means of its impress upon the antero-ventromedian, taken together with the configuration of the postero-ventromedian, and imprints upon it of the postero-ventrolaterals. For all practical purposes therefore, our knowledge of the ventral plates in G. verrucosa is sufficient to permit comparisons to be made with the armoring of other forms; and in the case of the extremely perfect outlines of G. abbreviata, one can see at a glance that a very different set of proportions obtained in the two species. As regards superficial ornament, the forms are related to each other much in the same way as are Bothriolep is $\mathrm{n}$ it id a and B. minor amongst Ostracophores.

The bone substance of the plate discovered by Dr Clarke is almost entirely denuded, leaving, however, a very clear impression of the external surface. Only the central portion of the plate is tuberculated, the surface sloping away on all sides of this area so as to form a broad, smooth peripheral margin, on which no traces of overlap are to be observed. The details of the ornamentation are shown to rather better advantage in the smaller fragment from the Black slate of Lexington, $\mathrm{Ky}$. The specimen here regarded as the type of a new species is from near the base of the Portage beds at Valois, N. Y., and is preserved in the New York State Museum. A somewhat larger plate, possibly identical with this, is to be seen in the collection of the Buffalo Society of Natural Sciences, and was obtained by Mr.Mixer from the Portage of Sturgeon Point, on the shore of Lake Erie. 
Formation and locality. Genesee of Eighteen Mile creek, N. Y., and Lexington, Ky. ; Portage of Seneca co. N. Y.

\section{Family MYLOSTOMATIDAE}

Head shield and abdominal armor essentially as in the preceding family, but with dentition adapted for crushing instead of cutting. Upper dentition consisting of two pairs of Ceratodontlike palato-pterygoid dental plates, with nondenticulate margins. Vomerine teeth present in at least one genus.

\section{Genus myLostoma Newberry}

Distinguishable from Dinichthys only by characters of the dentition. Oral surface of lower dental plates broad, more or less flattened, and bearing either a rounded boss or $\mathrm{V}$-shaped eminence close to the inner margin, which plays into a corresponding depression of the upper pair. Vomerine teeth as yet unrecognized.

Our knowledge of Mylostoma is confined at present to three species, all from the Cleveland shale of Ohio. Of these M. variabile Newberry, which is typical of the genus, has become comparatively well known within the last few years, thanks especially to the elaborate researches of Dr Bashford Dean. On the other hand, no additional material illustrating the characters of M. terrelli has come to light since the discovery of the unique type described by Newberry, now the property of the Museum of Comparative Zoology. One of the interesting points established by Dean's study of the type species is the close agreement between it and Dinichthys in all essential respects save for the dentition; and as regards this latter feature, the same difference is to be noted as exists between Rhynchodus and Palaeomylus amongst Chimaeroids, or between Protopterus and Neoceratodus amongst modern Dipnoans. Parallel modifications of this nature, occurring as they do in diverse groups, are doubtless to be correlated with similar food habits. Amongst Chimaeroids, for instance, certain genera are shown by their development of tritoral dental plates to have subsisted on hard-shelled prey, such as mollusks, echinoderms and the like; whereas others, as indicated by their sharp cutting blades, were 
adapted for subsistence on soft tissues, and were probably predaceous creatures. Mylostoma and Dinichthys furnish examples of corresponding adaptations amongst Arthrodires, and we have already seen that analogous changes are sustained amongst Dipnoans of the present day.

The mandibles of Mylostoma would seem to have retained with great persistency typical Dipnoan conditions. Not only do the dental plates portray what may fairly be called a Ceratodontlike configuration, but they

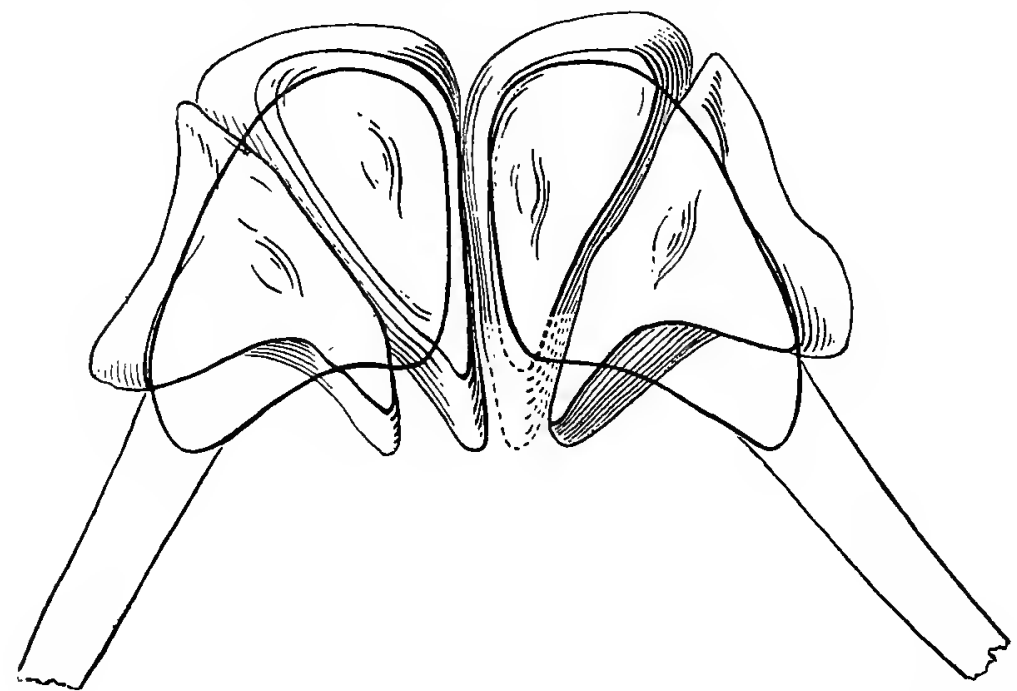

Fig. 3r Upper dentition of Mylostoma variabile Newberry, based upon a single, nearly complete example from the Cleveland shale near Cleveland, $O$. Nat, size

are more sharply demarcated from the supporting splenial than in other Arthrodires. And although marginal serrations have disappeared, the divided ridge which occurs close to the inner margin is perhaps to be regarded as a relic of one of the most persistent features of Dipnoan dentition. As for the upper dental plates, had they always been found in the detached condition, and were we ignorant of their association with typical Arthrodiran mandibles, they would be unhesitatingly identified with the Ctenodipterine order of Dipnoans. That these plates were supported in cartilage forming the roof of the month is perfectly evident from their rugose, slightly hollowed upper surface, and outwardly beveled edges; and the posterior contour of the hinder pair renders it extremely probable, at least, 
that the supporting palato-pterygoid cartilage was of the usual pattern found in all Dipnoans. This cartilage, when ossified, is commonly known as "upper dentigerous bone"; the fact that it is unossified in Arthrodires agrees with other evidence pointing to their lesser specialization as compared with Ctenodipterines.

The restoration of the upper dentition of M. variabile, shown in the above figure, requires no additional explanation beyond that given in the introductory account of Arthrodires. It may profitably be compared with text figure 18 , which is reproduced from a photograph of the actual dental plates. The retention throughout life of two pairs of palato-pterygoid dental plates in this family, corresponding to an evanescent stage of Neoceratodus, is regarded as a primitive characteristic. Hence, in so far as the dentition is concerned, members of this family recall ancestral conditions more distinctly than either Dinichthys or Coccosteus.

\section{Genus DinomyLostoma Eastman}

A genus transitional between Mylostoma and Dinichthys, as its name implies, and partaking of the characters of both. Mandibles with slightly prehensile symphysial beak, and broad, flattened, regularly concave functional margin, showing marks of contact with dental plates of the opposite jaw, the latter essentially like those of Mylostoma. Vomerine teeth subtrihedral, slightly prehensile.

\section{Dinomylostoma beecheri Eastman}

Plate $1_{4}$, figures 5,6 ; plate 15 ; text figure 32,33

I906 Dinomylost om a beecheri C. R. Eastman. Am. Jour. Sci. v. 21, ser. 4, p. 83 , text fig. 2 (No description)

$1906 \mathrm{D}$ i no m y los to m a be e che ri $C$. R. Eastman. Mus. Comp. Zool. Bul. 5o, p. 23, pl. I, fig. 4,5 ; pl. 2, fig. I3, I4, I6, I7; pl. 4, 5

1906 Dinomylost oma be e che ri L. Hussakof. Am. Mus. Nat. Hist. Mem.

9, p. I I 9,123

The specific characters of this form are included in the foregoing generic diagnosis. It may be remarked, however, that its particularly distinctive feature consists in the acute termination of both mandibles and 
vomerine teeth in front, together with the deeply concave oral margin of the lower dental plates. The functional surface of all the dental elements is narrower than in Mylostoma, thus making some approach to Dinichthyslike conditions, and a still further resemblance is to be observed in the form of the vomerine teeth. The latter, if found in the detached state, might readily be mistaken for the commonly so called "premaxillary teeth" of the preceding family. The dorsomedian and other plates of the abdominal armor are indistinguishable from those of Dinichthys.

The unique specimen upon which this species and genus are founded is extremely important for the light thrown upon the structure and relations of the group to which it belongs, besides acquainting us with an interesting connecting link between two well known genera of Arthrodires. Nearly the complete dentition is presented for study, besides portions of the head shield, suborbital, sclerotic ring, and several plates of the abdominal armor, including a nearly perfect dorsomedian. All of these parts were inclosed originally in a single block of shale; this has since been considerably broken, allowing a number of plates to be disengaged from the matrix.

The history of the specimen is as follows: collected in the year 1868 from an outcrop of Portage shale upon the farm of John Pierce, near Mount Morris, Livingston co. N. Y., it was acquired for the Peabody Museum at Yale by the late Professor O. C. Marsh. Here it remained for many years stored away and apparently forgotten. At all events there is no record of its consultation by any one prior to its being called to the present writer's attention by Professor Charles E. Beecher, shortly before the unfortunate loss to science of the latter. An opportunity for its description arising in connection with the present report, it was generously placed at the writer's disposal by his friend Professor Schuchert, of Yale, at whose suggestion the specific title was inscribed to the memory of the lamented Beecher. Although this specimen has already been noticed in the papers above referred to, its importance warrants further detailed description.

The dentition of this species presents features of absorbing interest. The mandibles bear a superficial resemblance to the lower dental plates of 
Palaeomylus, especially P. greenei, and they are constructed more nearly after the pattern of Dinichthys than of Mylostoma. This by no means allows us to suppose, however, that the Mylostomid type is a derivative of Dinichthys, or of its immediate predecessor, Coccosteus, inasmuch as the upper dentition in the family we are considering is decidedly more primitive than that of Coccosteans. The present species illustrates the manner in which the lower dental plates of Dinichthys and its allies may have become modified from the usual form of these organs amongst Dipnoan fishes, by becoming turned upright in the jaws and acquiring a trenchant functional margin through gradual compression. One can readily conceive the possibility

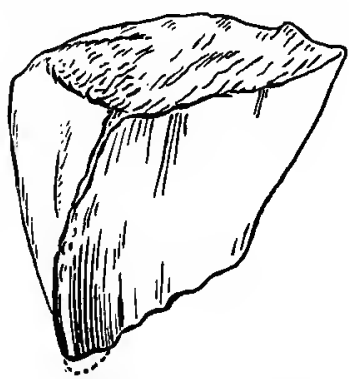
Fig. $3^{2}$ I.eft vomerine tooth
of Dinomylostoma bee cheri, as seen from in front and slightly to one side. of the palatopterygoid plates undergoing corresponding modifications, which resulted in the development of shear teeth.

In the mandibles of the species under discussion, the symphysial beak is rather obtuse, and but slightly prehensile, being scarcely elevated above the broad, flat, deeply excavated functional surface. The latter displays a single inconspicuous eminence or tubercle close to the external margin, situated about midway the length of the oral margin; and at a distance of about $8 \mathrm{~cm}$ behind the. anterior beak is a larger tubercle, rather elongate, and placed externally like the first. This posterior prominence fits accurately against the single large rounded boss of the opposing upper dental plate, thus determining the orientation of the latter with absolute certainty, and affording a trustworthy clue to the pasition of the corresponding element in M. variabile.

The splenial is developed as a long slender shaft of bone, resembling that of Dinichthys, but relatively deeper. Both of these elements, right and left, are preserved in natural association with the articular cartilage. This has become more or less compressed through fossilization, but remains attached to the outer face of the splenial near its posterior extremity. Owing to the favorable preservation of the specimen, we are now enabled 
for the first time to identify positively the elements of the lower jaw in Arthrodires, and to ascertain the nature of its articulation with the head shield. That the shaft of bone which we have called the splenial is properly determined as such follows necessarily from the rule that in all higher types of fishes and other vertebrates, the functional lower jaw is formed by membrane bones which become ossified around Meckel's cartilage. In their greatest development there may be several of these bones on either side, amongst which the dentary is defined as that bone which is developed in front - usually it is dentigerous - and the splenial that which is developed further back on the inner sidc. The angulare, when present, extends forward from the angle of the lower jaw to meet the other two, and in addition a supra-angulare sometimes occurs behind the articulation of the lower jaw with the quadrate. Meckel's cartilage itself never ossifies, but remnants of it may persist in grooves or otherwise, as has already been observed. The mandibles of Dinomylostoma are of peculiar importance in that their constituent parts are found to correspond precisely with those of Dipnoan fishes.

The vomerine teeth of the present species are readily identifiable as such, owing to their general similarity to the corresponding structures in Dinichthys. They are prehensile to about the same degree as the symphysial beaks of the lower jaw, against which they closed. Their posterior face is smooth and slightly concave, as if they had been in direct apposition with the anterior pair of palato-pterygoid dental plates, but these latter are missing in the only known example. The hinder pair, however, is admirably preserved, and, its position being definitely fixed in the manner already indicated, it is not difficult to restore the general outline, at least, of the missing elements. Their external margin must have been parallel to that of the functional surface opposed to them in the lower jaw; and as they were probably in contact along the median line, the inner ma in was rectilinear, as in Mylostoma variabile. An inspection of text igure 32 will facilitate an understanding of the manner in which upper and lower dental elements closed together, it being borne in mind that the tips of the vomerine and mandibular pair of plates were directly opposed. 
Measurements of the more characteristic elements may be given as follows: the vomerine teeth have a length along the inner longitudinal margin of $3 \mathrm{~cm}$; their width across the posterior face is $3.5 \mathrm{~cm}$, and across the external face it is $4 \mathrm{~cm}$. The posterior palato-pterygoid dental plates are of irregularly cruciform outline, with major and minor axes of 6.8 and $5 \mathrm{~cm}$ respectively. They are about $2 \mathrm{~cm}$ in thickness, except in the region

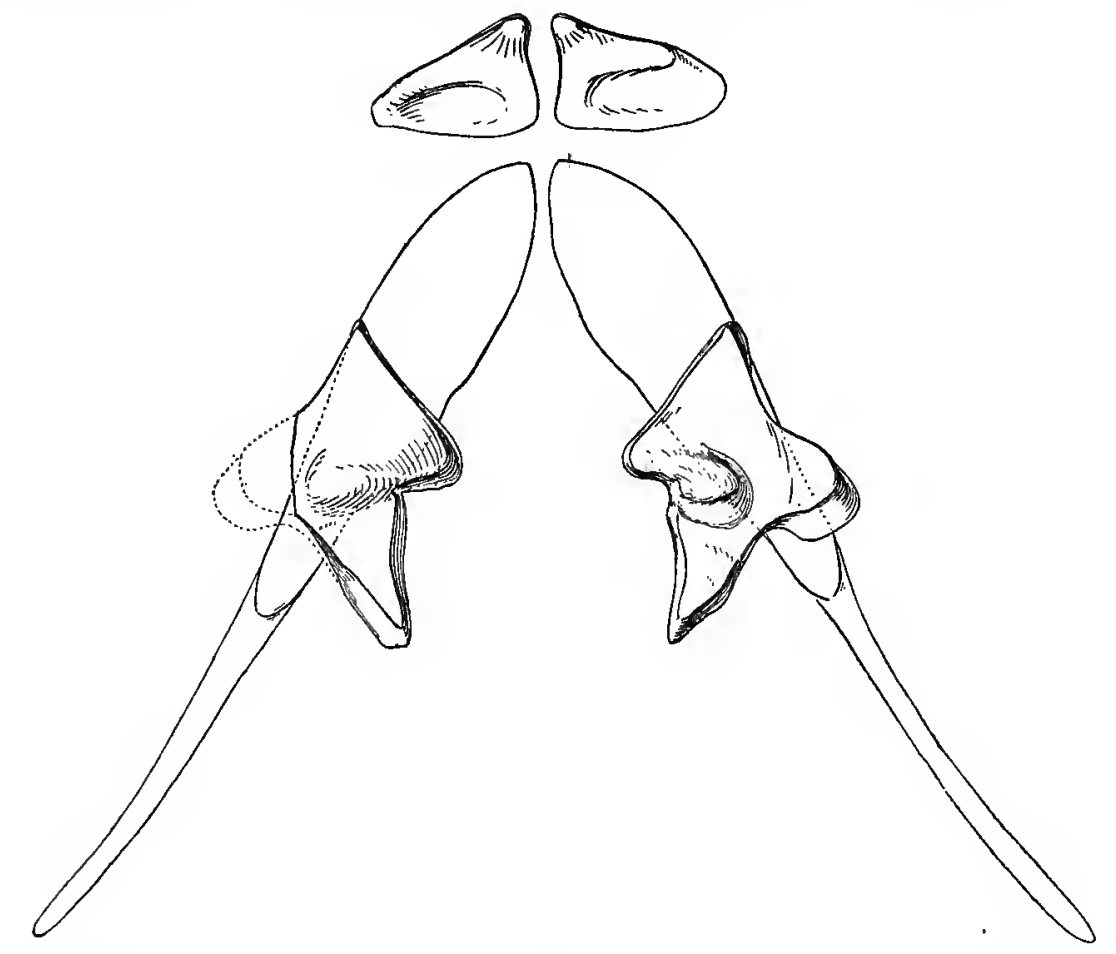

Fig. 33 Diagram showing contour of oral margin of mandibular and posterior palato-pterygoid dental plates of Din o m ylos tom a be c cheri, in front of which are shown the upturned vomerine pair, all drawn to the same scale, and the members of each pair placed in natural position with respect to each other. $x^{1 / 2}$

of the centrally placed tubercle, where the total thickness is $2.5 \mathrm{~cm}$. The total length of the mandibles falls a trifle short of $20 \mathrm{~cm}$, that of the functional margin about $8 \mathrm{~cm}$, and the maximum width of the latter is $2.3 \mathrm{~cm}$. The dorsomedian plate, closely similar in form to that of $\mathrm{Dinich}$ thys in termedius, and with well developed posterior process, is estimated to have had a total width of at least $18 \mathrm{~cm}$; it is unfortunately not preserved for its entire length. The antero-ventrolaterals have approximately the 
same form, but are in the neighborhood of one fifth smaller than the corresponding plates in the unique example of Mylostoma variabile figured by Dean. It is necessary to bear in mind, however, in connection with this author's restoration of the ventral armor, that the anterior and posterior pairs of lateral plates have been confused with one another. Such, at least, is the opinion of the present writer after comparison of the plates marked by him " $A V L$ " and " $P V L$ " with the ventrolaterals of Dinichthys and noting specially their centers of ossification, growth-lines, and nutritive canals.

Formation and locality. Portage (Cashaqua) shale; Mount Morris, N. Y. There is also indistinct evidence either of this or of some species of Mylostoma in the black Naples shale (Portage) at Sturgeon Point, on the south shore of Lake Erie.

\section{GENERA OF DOUBTFUL FAMILY POSITION}

Fragmentary remains of Arthrodires, differing from other described species as regards superficial ornament, and some of them indicating fishes of considerable size, have been described from various Devonic localities of the New York-Pennsylvania region. Most of the species are known only by detached plates, none in association with the dentition, hence their systematic position is doubtful. Coarsely tuberculated plates, suggestive of Newberry's type of Aspidichthys clavatus, are reported from the New York Portage. ${ }^{2}$ As indicated by the generic name, the ornament of Holonema consists of threadlike, radiating ridges. Two species are known, the type (H. rugosum Claypole) occurring in the Chemung of New York and Pennsylvania, and the other (H. horridum Cope) thus far known only from rocks of the same age in Bradford county, Pennsylvania. One specimen of $\mathrm{H}$. rugosum is interesting in that it displays the entire ventral armor. Phyllolepis is distinguished from Holonema by having the superficial rugae arranged in concentric, instead of radiating

I Dean, B. Palaeontological Notes: On the Characters of Mylostoma Newberry. N. Y. Acad. Sci. Mem. 1901. 2: 108, pl. 7.

- Williams, H. S. U. S. Geol. Sur. Bul. 4I. 1887. p. 43. 
lines. The only American species known is P. delicatula Newberry, from the Chemung of Bradford county, Pennsylvania. Accompanying the latter, but of still more problematical nature, are plates with arrowheadlike ornamentation, described by Newberry under the name of $\mathrm{Spheno-}$ phorus lilleyi. ${ }^{x}$ Certain elliptical plates having a closely similar style of ornamentation are also known from the Hamilton of Milwaukee. From this locality also are obtained a number of peculiar plates, possibly representing the dorsomedian of unknown forms, two such being shown in plate 2, figures 3 and 4. Aspidichthys, Phyllolepis, and possibly also Holonema, are represented in the European Devonic, and one species from the Devonic of Manitoba is doubtfully referred to Aspidichthys (A. ? notabilis) by Whiteaves.

\section{Order CTENODIPTERINI}

Body fusiform, without dermal armor. Skeleton and chondrocranium partially ossified, skull autostylic, premaxillae and maxillae absent. Cranial roof bones small, and, like the squamation, with or without ganoin investment. Nostrils inferiorly situated; jugular plates present or not. Tail heterocercal or apparently diphycercal (gephyrocercal). Anal fin always distinct, the remaining median fins either discontinuous or becoming coalesced. Paired fins acutely lobate. Secondary pectoral arch consisting of ossified supraclavicular and clavicle; pelvic arch present. Dentition consisting of large tritoral dental plates supported by the palato-pterygoid and splenial bones; a marginal series of teeth above and below also sometimes present, but never any vomerine teeth.

The structure of this singularly interesting order of Paleozoic fishes has been investigated in minute detail by Pander, Traquair and others, and particularly within the last dozen years or so its relations to modern lung fishes have engaged profound attention amongst students of ichthyology and paleontology. Recent discussion has centered around two rival theories, as we have already seen. According to the first, which has steadily gained in ascendancy, the typical Dipnoans of the Devonic are

The generic name being preoccupied, Oestophorus has been proposed as a substitute by S. A. Miller. Plates of this description occur also in the Hamilton. 
supposed to have attained greater specialization than any of their known descendants in later times, those existing at the present day showing decidedly more primitive characters as compared with Ctenodipterines. Modern forms would therefore be looked upon as survivals of the more generalized primeval Dipnoan stock, rather than as the direct descendants of Dipterus and its allies.

The other and newer interpretation is that of Dollo, and directly the reverse of the first. Evidence drawn from other than cranial characters is held to confirm the belief that Dipterus is the most archaic of all Dipnoans, and that modern lung fishes have been derived through successive stages of specialization. As starting point of this theory, Dollo accepts the conclusion previously reached by Balfour and Parker that the apparently diphycercal tail of recent forms is secondary, due to abortion of the termination of the vertebral axis, and coalescence of the median fins. The less ossified condition of the skull in modern forms is likewise explained as the result of secondary reversion, through degeneration, to an apparently primitive condition. The chief objection to this view is that we are unacquainted with any parallel example amongst vertebrates which justifies belief in the possibility of such degeneration as is here assumed.

Yet another view of Dipnoan relationships, or perhaps rather to be considered as a modification of the first, is that already outlined in the present memoir. The Ceratodont type is regarded as decidedly more primitive in structure than that of Dipterus and its allies; and either it or its direct prototype is assumed to have been in existence at least as early as the lowermost Devonic, to have given rise to the highly specialized orders of Ctenodipterines and Arthrodires, and to have persisted practically unchanged ever since. Neoceratodus therefore falls within the same category as scorpions, king-crabs, Lingula, Cestracion and other archaic survivals which have manifested extraordinary persistence and conservatism throughout nearly the whole sequence of geological formations. This view may be said to rest almost entirely upon the evidence of comparative anatomy, and has received as yet no confirmation through the discovery of 
actual remains which fulfil the requirements of a common ancestor to the three recognized orders of lung fishes, - Arthrodires, Ctenodipterines and Sirenoids. It may be that confirmation of this nature will never be forthcoming, owing to the imperfection of the paleontological record. Nevertheless, guided by the principles of structural resemblances, and not by any exercise of the art of divination, one may project the divergent lines of descent backward until they meet in a common point; and at this point is to be sought the ancestry of the three orders with which we are now acquainted.

\section{Family DIPTERIDAE}

Cranial roof bones numerous; no secondary upper jaw, and no marginal series of teeth above or below; jugular plates present. Upper and lower dental plates triangular, with outwardily radiating ridges, usually tuberculated or strongly crenulated, rarely smooth or nearly so; no vomerine teeth. Caudal fin heterocercal; two remote clcrsal fins opposed to the pelvic and anai fins, separated from the caudal.

\section{Genus DIPTERus Sedgwick \& Murchison}

Our knowledge of the complete form of this genus, shown in text figure 34 , is dependent entirely upon the well preserved skeletons occurring in the Scottish Lower Old Red sandstone. In this country Dipterine remains are

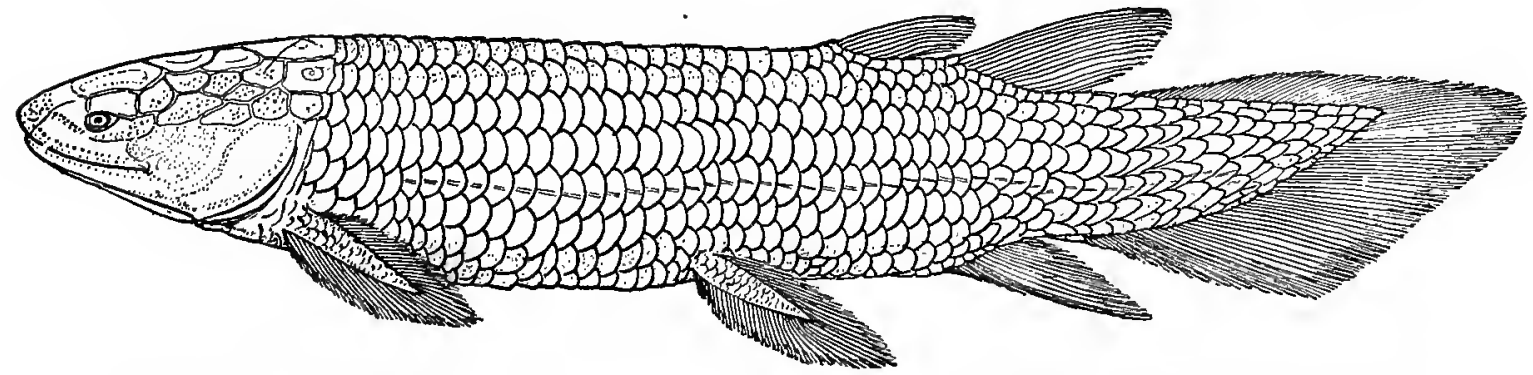

Fig. 34 Dipterusvalenciennesi Sedgw. \& Murchison. Lower Old Red sandstone; Scotand. Lateral aspect, restored. $x \frac{3}{4}$ (From Dean)

confined exclusively to detached hard parts, such as dental plates, scales, and calcified labial cartilage. Under these circumstances it is sometimes difficult to determine whether teeth of a certain form should be retained in 
this genus, or referred to Sagenodus, Ctenodus, and others having a similar form of dentition. Recent discoveries having brought to light large numbers of Dipterine teeth from the western Devonic, the leading species which are here figured and described offer valuable points of comparison with those from the eastern States.

\section{Dipterus uddeni Eastman}

Plate 4 , figures 3,4

1899 Dipterus uddeni $J$. A. Udden. Jour. Geol. 7:494 (name only)

r 900 Dipterus udden i $C$. R. Eastman. Jour. Geol. 8: 37, text-fig. 5

This species, the earliest to make its appearance in the Devonic rocks of this country, is founded upon a unique lower dental plate from the base of the Cedar Valley limestone (Erian) near New Buffalo, Ia. The specific title is bestowed in honor of its discoverer, Professor J. A. Udden, formerly of the Iowa State Geological Survey. It has a total length of $36 \mathrm{~mm}$, is moderately convex, and remarkable for the paucity of its denticulated ridges. These are but four in number, and radiate outwards from the posterior angle, which is worn smooth by use. The anterior row of denticles, and inner moiety of the remaining rows are also considerably worn; but in the outer moiety of these rows the denticles are acutely conical, of large size, and well separated. There is a gradual increase in size of all the denticles from within the inner margin outwards. The coronal surface is finely punctate.

Formation and locality. Base of the Cedar Valley limestone; New Buffalo, Ia.

\section{Dipterus calvini Eastman}

\section{Plate 4 , figure I}

1900 Dipterus calvini C. R. Eastman. Jour. Geol. 8: 38 , text fig. 7

Lower dental plate elliptical in outline, and moderately convex in an anteroposterior direction. Eight tuberculated ridges extend from the outer margin to about the middle of the plate, the two anterior ones larger than the rest and elevated into a slight fold. Coronal surface considerably worn in the type specimen, and external margin partially broken. Tubercles 
conical and well separated, except those of the two anterior ridges, which are coalesced and worn on their summits. Total length of plate $3 \mathrm{~cm}$.

This species, like the preceding, is founded upon a unique dental plate from the Cedar Valley limestone of Iowa. It comes, however, from a higher level, locally known as the "Euomphalus bed," which lies about eight feet below the summit of the Middle Devonic in Muscatine county.

Formation and locality. Cedar Valley limestone; Fairport, Ia.

\section{Dipterus costatus Eastman}

Plate 4, figure 9

Igoo Dipterus costat us C. R. Eastman. Jour. Geol. 8: 39 , text fig. 4

Dental plates agreeing in size and general outline with D. calvini, but with fewer and more widely separated coronal ridges, which disappear before reaching the middle of the plate. The distinguishing feature of this species consists in the elevated acute ridge extending along the entire length of the inner border, and separated from the remaining tuberculated ridges by a broad longitudinal furrow. This ridge appears to be made up of three coalesced costae, of which the third counting from the inner margin is the largest. The two innermost costae are so faint as to be almost imperceptible against the steep face of the main ridge. The latter shows no evidence of having been tuberculated, although faint and partially coalesced tubercles occur on the five remaining costae. Several examples of this species, including the type, are preserved in the Museum of Comparative Zoology at Cambridge, Mass.

Formation and locality. State Quarry beds (Upper Devonic); near North Liberty, Johnson co., Ia.

\section{Dipterus mordax Eastman}

Plate 4, figures 5,6

Igoo Dipterus mordax C. R. Eastman. Jour. Geol. 8: 39 , text fig. 6, 8

Lower dental plates attaining a length of over $3 \mathrm{~cm}$, coronal surface gently convex, with six rows of very large, discrete, conical or rounded tubercles which extend from the outer margin for a variable distance toward the posterior angle; the two posterior rows often rudimentary. Some of 
the tubercles, when worn by use, become elongated in the direction of the rows to which they belong, others in an oblique direction. The coarseness of tuberculation, in proportion to the size of the plates, is greater than in any other species yet described.

Formation and locality. State Quarry beds (Upper Devonic); near North Liberty, Johnson co., Ia.

\section{Dipterus fleischeri (Newberry)}

Plate 7, figure 2

I897 Ctenodus fleischeri J. S. Netuberry. N. Y. Acad. Sci. Trans. 16: 302, pl. 24 , fig. 25

Upper dental plates thin, slightly concave, triangular in outline; coronal surface transversed by six rows of rounded obtuse tubercles increasing in size from the posterior angle outwards. At least the anterior or innermost rows of tubercles are continuous almost to the posterointernal angle.

Besides the type, only one other example of this species has yet been brought to light. This is a large upper dental plate, preserved in counterpart, now the property of the New York State Museum. It is from the Catskill of Delaware county, N. Y., and being more complete than Newberry's original, we present a figure of it herewith. Its relations are evidently with D. uddeni and D. mordax, as shown by the small number of coarsely tuberculated costae; but in size it is much larger, the length of the inner margin being fully $5 \mathrm{~cm}$.

Formation and locality. Catskill sandstone (Chautauquan); Tioga county, Pennsylvania, and Franklin, Delaware co. N. Y.

Dipterus sherwoodi Newberry

I875 Dipterus sherwood i J. S. Netwherry. O. Geol. Sur. Rep't. Palaeont. v. 2. pt 2, p. 6r, pl. $5^{8, \text { fig. } 17}$

I889 Dipterus (Ctenodus) sherwoodi J. S. Newberyy. U. S. Geol. Sur. Monogr. i6: i 8 , pl. 27 , fig. 32

Of this species no other examples are known but the type specimen, which is imperfect. In the text of Newberry's monograph, this is determined as "apparently one of the upper palate teeth of a species of Dip- 
terus," but in the explanation of figures it is identified as a mandibular dental plate. It agrees with the preceding species in having a coarse tuberculation and very few ridges, some of them indistinct. The tubercles themselves are stated to be "somewhat compressed laterally, rounded, smooth, and blunt at the summit."

Formation and locality. Catskill sandstone (Chautauquan); Tioga county, Pennsylvania.

\section{CHEMUNG SPECIES OF DIPTERUS}

Precise determination of Dipterus teeth from the Chemung proper of New York and Pennsylvania is a matter of some difficulty, owing to imperfection of type material upon which the various "species" are founded, and an insufficient series of specimens for illustrating the range of variation common to both sets of dental plates, upper and lower. In the case of some species, the original descriptions undoubtedly require emendation, but it would be hazardous to attempt this without having recourse to a larger and better suite of material than is at present available amongst different museums. This much, however, one feels warranted in concluding: that very probably not more than two well marked types of Dipterine teeth occur in the Chemung proper of the eastern region. These are D. flabelliformis and D. nelsoni Newberry, the latter including Newberry's so called D. levis (founded on worn specimens), and possibly also D. quadratus and minutus. Of Dipterus nelsoni both palatine and mandibular dental plates are known, a good example of the latter being represented in plate 4 , figures 13,14 . For the original description of these forms, which we are willing to leave as they are for the present, one may consult Newberry's monograph, pages 87-9I. Whether the so called Dipterus ithacensis, considered by Williams" as "showing some relationship perhaps to Pterichthys," properly belongs in this category can not be determined from the meager account given of it, unaccompanied by illustrations.

${ }^{1}$ Williams, H. S. Notes on some Fish-remains from the Upper Devonic of New York State (Abstract). Am. Ass'n Adv. Sci. 3oth meeting. Proc. I882. p. I92. 
On the other hand, Dipterine remains are present in astonishing abundance and considerable variety in the western Neodevonic, specially the State Quarry beds of Johnson county, Iowa. A number of representative forms, some of them belonging to still undescribed species, are shown in plate 2, figure I, and plate 4, figures $2,7,8,12,15$ and 16 . It is to be regretted that no portions of the skeleton, other than the dentition, have yet been brought to light from this region.

\section{Subclass TELEOSTOMI}

The great group of fishes commonly known under the designations of Ganoids and Teleosts and first recognized by Owen as a single subclass, Teleostomi, makes its appearance in the Lower Devonic, but does not really become significant until the Carboric. The Crossopterygian order, which predominates during the Devonic, is somewhat abundantly represented toward the close of that system in this country; but except in Canada, all the remains are extremely fragmentary, consisting of detached scales, teeth, plates, and in two or three instances of imperfectly preserved skeletons. The most important American genera are Holoptychius, Sauripterus, Onychodus and Eusthenopteron, but of these the last named alone has been found in a state bordering upon completeness. Nevertheless, it is possible to frame a tolerably accurate conception of the remaining genera through comparison of their characteristic parts with the admirably preserved skeletons of their foreign representatives, especially those from the Scottish Old Red sandstone. In this way the detached head plates and bones of the shoulder girdle belonging to Onychodus, for instance, acquire much greater significance than would otherwise be possible. The osteology of various typical members of the Crossopterygian order is now quite satisfactorily known, as the result especially of the researches of Pander, ${ }^{1}$ Huxley ${ }^{2}$

- Pander, C. H. Ueber die Saurodipterinen, Dendrodonten, Glyptolepiden, und Cheirolepiden des devonischen Systems. St Petersburg I860.

a Huxley, T. H. Illustrations of the Structure of the Crossopterygian Ganoids. Geol. Sur. Mem. United Kingdom a 866. Reprinted also in the Scient. Mem. of T. H. Huxler, Suppl. volume, I9o3. 
and Traquair. To the last named author, ${ }^{x}$ also, we owe our principal knowledge of the structure of Paleoniscid fishes, these being the only Devonic representatives of the next higher order of Teleostomes, or Actinopterygii.

\section{Order I CROSSOPTERYGII}

Pectoral fins lobate, with a large basal portion covered with scales, more or less fringed with dermal rays; the ventrals usually much like the pectorals, always abdominal in position; caudal fin diphycercal or heterocercal. Skeleton more or less ossified, body covered with rhombic or circular ganoid scales. A pair of large jugular plates developed in place of branchiostegals; no fulcra. Dorsal fins two, or a single one divided into many finlets.

Attention has frequently been called to the fact that the earliest members of this order, especially those with acutely lobate paired fins, bear a considerable resemblance to Dipnoans, and the descent of the latter has even been traced by Dollo and others to the Crossopterygii. These fishes possess much general interest in that they are commonly looked upon as ancestral to amphibians and higher vertebrates. During the evolutionary history of the order, the following structural modifications are observable, as noted by A. S. Woodward: (I) The paired fins become abbreviated; (2) the supports of the median fins tend towards reduction to a single series; (3) these supports sometimes become correlated in part with the dermal fin rays; and (4) there is sometimes degeneration in the external armor of the head and opercular region, some plates being fused together, others becoming lost. The reduction in the complexity of the mandibular ramus is also especially noteworthy.

\section{Family HOLOPTYCHIIDAE}

Body fusiform, with cycloidal, deeply overlapping scales, more or less enameled. Head and opercular apparatus with well developed membrane bones; parietals large and separate; frontals separate, not fused into a con-

- Traquair, R. H. Ganoid Fishes of the British Carboniferous Formations. Pt I, Palaeoniscidae. Pal. Soc. Monogr. 1877 and rgor. 
tinuous plate with the adjoining elements; no parietal or frontal foramen ; interoperculum absent ; jugular plates comprising one large pair, flanked on either side by a lateral series. Dentary bone of mandible thin and deep, bearing a series of small teeth, and with well developed infradentaries, much bent inwards below; an inner series of few, large, broad, shuttle-shaped bones, each supporting a "laniary" tooth; a pair of similar teeth on the roof of the mouth, but the marginal upper dentition feeble. Teeth conical, with a very small pulp cavity, of which the walls exhibit complex infoldings, appearing closely intertwined when viewed in transverse section, these producing superficial vertical flutings. Pectoral fins acutely lobate, pelvic fins either acutely or obtusely lobate; two remote dorsal fins; anal fin single; caudal fin diphycercal or heterocercal.

The foregoing family definition, which we have taken from Smith Woodward, is based chiefly upon the structural characteristics of the typical genus Holoptychius, well preserved specimens of which occur plentifully in the Scottish Old Red sandstone, and are known also from Belgium and Russia. With the exception of the closely related Glyptolepis quebecensis Whiteaves, ${ }^{2}$ by some writers included with Holoptychius, no member of this family is represented in the American Devonic by completely preserved remains, and by far the majority of species are founded upon detached scales. The teeth described by Leidy under the name of A pedodus priscus, ${ }^{2}$ from the Catskill of northern Pennsylvania, examples of which are figured in plate $\mathrm{I}$, figures $\mathrm{I}, 2$, do not appear to differ from those of Holoptychius by any recognizable characters. On the other hand the accompanying Sauripterus taylori, ${ }^{3}$ founded on portions of a fish closely similar to Holoptychius, is proved by the less complicated structure of the teeth and obtusely lobate condition of the pectoral fins, to agree

I Whiteaves, J. F. Roy. Soc. Can. Trans. v. 6. (1889). $\quad$ 4, p. 77, pl. 5, fig. 4.

${ }^{2}$ Leidy, J. Acad. Nat. Sci. Phila. Jour. ser. 2. v. 3. I856. p. I64, pl. I7, fig. $5,6$.

${ }_{3}$ Hall, J. Nat. Hist. New York, pt 4. Geology. 1843. p. 282, text fig. I30. The same specimen is further noticed by J. S. Newberry, U. S. Geol. Sur. Monogr. 1889. I6: I r , but is not figured. Type preserved in the American Museum of Natural History, New York, 
more closely with Rhizodonts, and is definitely assigned to that family by Voodward. The enlarged scale ornament of the type specimen described by Hall is shown in plate 7 , figure 9. A fairly accurate concept of the appearance presented by several Crossopterygian and other typical Devonic fishes is afforded by the restoration given in text figure 35, for which we are indebted to Mr F. A. Lucas, author of Animals bcfore Man in North America and other popular works.

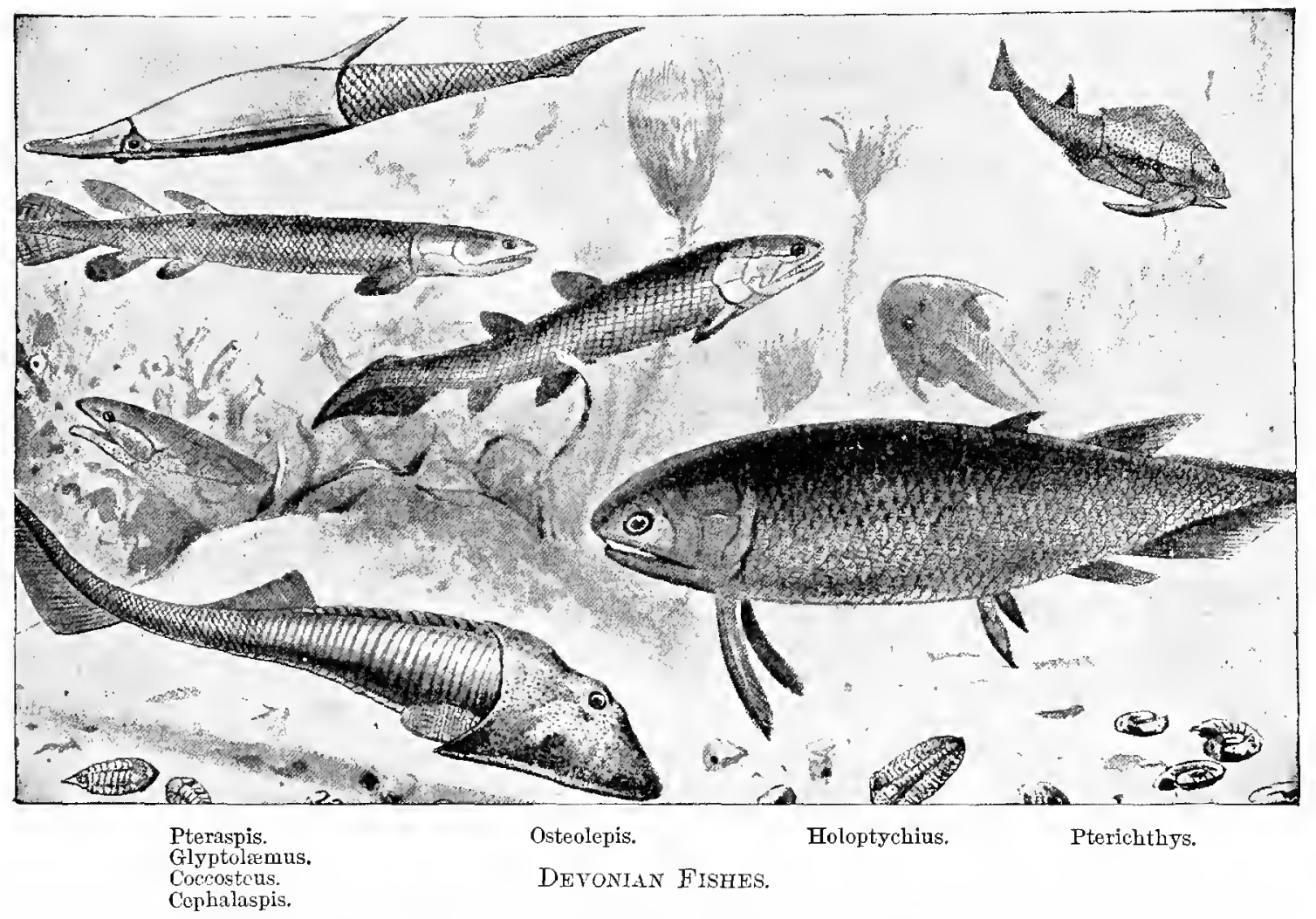

The most commonly occurring scales of Holoptychius in the American Devonic, and at the same time the most widely distributed, are those of H. giganteus Agassiz, and H. americanus Newberry. They are found not only in the Catskill of New York and Pennsylvania, (H. a meric a n u s occurs in the Chemung of Delaware county as well), but also in the Upper Devonic of southwestern Colorado, The scales of H. giganteus 
are very large, those of the abdominal region externally ornamented with close, thick, irregularly tortuous, longitudinal ridges, often branching and interrupted, more or less replaced posteriorly by rounded tubercies. In H. a mericanus the ridges are subparallel, strong, flexuous and sometimes inosculating, but not broken up into tubercles or interrupted to any appreciable extent. H. halli Newberry, from the Catskill of Delhi, N. Y., is known by a unique example which displays a portion of the trunk, and is covered with smaller and thinner scales than those of $H$. a mericanus. The type of this species is preserved in the New York State Museum at Albany. Other species described from the Catskill of Pennsylvania are H. flabellatus, H. 1 at us and H. serrulatus Cope; and from the Chemung of the same state are known H. filosus Cope, H. granulatus, H. pustulosus and H. tuberculatus Newberry. A single scale belonging to an undetermined species of Holoptychius is also reported by H. S. Williams from the Chemung of Wellsville, Allegany co., N. Y.

\section{Family ONYCHODONTIDAE}

Scales cycloidal, deeply overlapping. Head and opercular apparatus with well developed membrane bones. Dentary bone of mandible thin and deep, bearing a single close series of large conical teeth, flanked by an outer series of very minute teeth; an azygous series of large more or less recurved teeth attached in front of the symphysis. Teeth plicated only at the base, with a central cavity; dentary teeth tipped only, presymphysial teeth completely enveloped with enamel.

But a solitary genus, Onychodus, is at present known to represent this family, and its remains have hitherto been found only in a fragmentary condition. Such bones of the cranial roof and pectoral girdle as are known suggest a certain resemblance to the Holoptychiidae and Rhizodontidae. The tooth structure, however, is simple, and a conspicuous difference exists in the presence of a dentigerous presymphysial bone. The external bones and scales of the type species, O. sig moides Newberry, are ornamented

- Williams, H. S. On the Fossil Faunas of the Upper Devonic. U. S. Geol. Sur. Bul. 4. 1887 . p. 78 . 
with fine tuberculations, more or less conical, and radiately grooved. The clavicle is triangular in shape, with relatively large inferior limb; and the infraclavicle is without an elongated ascending process. In this species, also, the presymphysial bone is very prominent, its teeth being much larger than those of the dentary. Remains of O. sigmoides are not uncommon in the Columbus and Delaware limestones of Ohio, and probably occur also in the Onondaga limestone of Leroy, N. Y. A few detached presymphysial teeth comparable in a general way to this species are also known from the Hamilton of Milwaukee, Wis., one such being figured in plate 1, figure 3 ; others, with less pronounced sigmoidal curvature, are present in the Middle Devonic of the Eifel district. As an example of the latter a single tooth belonging to the Cambridge Museum is represented alongside of the Hamilton form in the same plate for comparison.

By far the most abundant of any species of this genus is that which Newberry described under the name of $\mathrm{O}$. hopkinsi, occurring typically in the Chemung of Delaware county, N. Y., but being also represented in enormous quantities in the basal bituminous layer of the Marcellus shale of the same State. The teeth are not satisfactorily distinguished from those of the type species, but are of prevailingly smaller size, and somewhat lesser curvature. The average length is stated by Newberry to be about I inch. This, together with the considerable stratigraphic interval separating them from $O$. sigmoides, probably furnishes sufficient reason for their maintenance as distinct species. A series of five well preserved presymphysial teeth belonging to this species, from the Chemung of Franklin, N. Y. is shown in plate 3 , figure 3 .

An undeternined species of Onychodus seems to be indicated by a few detached plates and other fragments from the Cedar Valley limestone (Mesodevonic) of Iowa, and Hamilton of Oran, Onondaga county, N. Y. A single detached scale from the latter locality, with characters indistinguishable from those of the type species, is shown in plate 3, figure 2. Scales displaying a Coelacanthuslike ornamentation, but generically indeterminate, occur also in the Portage beds of Livingston county, New York. 


\section{Order ACTINOPTERYGII}

Paired fins nonlobate, having an extremely abbreviated endoskeletal portion, and the dermal rays prominent. Caudal fin abbreviate-diphycercal, heterocercal, or homocercal. A single paired series of transversely elongated rays, with or without an anterior azygous element, developed in the branchiostegal membrane between the mandibular rami.

\section{Suborder CFONDROSTER (Sturgeons)}

In these fishes, the oldest and most primitive of the Actinopterygii, the notochord is more or less persistent, the supports of the dorsal and anal fins are less numerous than the dermal rays opposed to them, the paired fins are more abbreviate than in the Crossopterygian order, and the tail is completely heterocercal. Primitive sturgeons also differ from Crossopterygian fishes in the development of a paired series of transversely elongated branchiostegal rays to replace the pair of jugular plates between the mandibular rami; infraclavicular plates, however, are retained in both groups. Nearly all of the older forms have a well developed rhombic and ganoid squamation. So far as known the chondrocranium is but little ossified, and the cranial bones are mainly dermal.

The evclutionary history of the Sturgeon tribe has been thus briefly recapitulated by Professor Bridge in the following paragraph $:^{x}$

The Chondrostei are first represented in the Lower Devonic by the solitary Palaeoniscid genus Cheirolepis, a contemporary of the earliest Crossopterygii. They occur throughout the Mesozoic period, except in the Cretaceous, and also in the Eocene, and while steadily diminishing in number and variety, they gradually approximate to their degenerate and in some respects highly specialized descendants, the sturgeons and paddlefishes of the existing fish fauna. Of the seven families included in the group, the Palaeoniscidae are the oldest and most generalized. The Platysomidae are a specialized offshoot from the Palaeoniscidae, and, if they are rightly to be considered as Chondrostei, perhaps the same may be said of the problematic Belonorhynchidae. On the other hand, there are certain features which indicate an approach to fishes of an altogether more modern type. Finally, the Chondrosteidae represent a stage in a career of

${ }^{3}$ Fishes, Ascidians, etc. Cambridge Natural History. 1904. p. 487. 
degeneration, the climax of which is reached by the modern Polyodontidae and Acipenseridae.

\section{Family PALAEONISCIDAE}

Primitive Chondrostei with fusiform bodies, short dorsal and anal fins, and usually with a complete investment of articulating, rhombic, rarely cycloid, ganoid scales. Fulcra generally present at the bases of the median fins, and especially along the dorsal border of the upper caudal lobe. Ribs are not known to be present. Skull invested by a very complete series of paired dermal bones, which in number and disposition conform to the normal Teleostome type. The secondary upper jaw includes both premaxillae and large maxillae; and, as a rule, both the dentary and splenial bones of the lower jaw are dentigerous. Except for the absence of an interoperculum, the opercular series of bones is complete, including numerous branchiostegal rays. There is a single small median jugular plate [Bridge, loc. cit. p. 486].

The earliest representative of this family, and of Sturgeons generally, is the genus Cheirolepis, which is remarkable for the very small size of its scales. The typical species, C. trailli, occurs in the Old Red Sandstone of northern Scotland, and another well preserved form, described by Whiteaves as C. canadensis, is known from the Upper Devonic of the Province of Quebec. Aside from the Canadian form, no completely preserved individuals are known from the Devonic rocks of this continent, although three species have been founded upon portions of the squamation. These latter have been doubtfully assigned to the genus Palaeoniscus, and are named as follows: P. antiquus and P. reticulatus Williams, and P. devonicus Clarke. ${ }^{2}$ The two first named are from the Portage beds near Buffalo, N. Y., and the last named, much better preserved than the others, is from the Rhinestreet (Portage) beds of Sparta, N. Y. The scale characters of the Portage species point to an association with the genus Rhadinichthys, and from their size and arrangement it is probable

'Williams, H. U. Buffalo Soc. Nat. Sci. Bul. I 886 , 5:84, fig. 2.

'Clarke, J. M. U. S. Geol. Sur, Bul. I6. r885. p. 20, 41, pl, I, fig. 2, 6. 
that complete individuals attained a length of about I $_{5} \mathrm{~cm}$. Similar cletached scales are reported also from the Genesee shale at Glenville, N. Y., and in the equivalent Black slate of Kentucky.

Rather better preserved than any of the last mentioned remains, yet unfortunately not affording precise indications of its relationships, is the trunk and imperfect head portion of a small, thick scaled, and relatively large finned Palaeoniscid fish from the Chemung of Warren, $\mathrm{Pa}$. The squamation of one of the counterparts of this example is photographed in natural size in plate 9, figure 4 , and an enlarged view of the abdominal portion in which the fins and dorsal ridge scales are well displayed, is given in plate 4, figure i i. Directly below in the same plate is shown an enlarged view of one of the pectoral fins, in natural association with the distorted plates of the jugular region. The form of body, position of fins and minute scale characters agree somewhat closely to the corresponding features of several small species of Rhadinichthys described by Dr Traquair from the Lower Carbonic (Calciferous sandstone series) of Scotland. ${ }^{.}$Nevertheless, owing to the present condition of the specimen, and the fact that it thus far remains unique, materials are lacking for framing a satisfactory specific diagnosis, or even for affirming with certainty that it belongs to the genus Rhadinichthys. Under these circumstances it appears inadvisable to desiynate it by a distinct specific title. It is greatly to be hoped that further search may be rewarded by the discovery of more perfect material of this nature.

r Traquair, R. H. Report on Fossil Fishes collected by the Geological Survey of Scotland in Eskdale and Liddesdale. Roy. Soc. Edinburgh Trans. I88x. v. $3^{\circ}$, pt $\mathrm{x}, \mathrm{p}$. I5-7I. 


\section{SUMMARY AND CONCLUSIONS}

The immediate purpose of the foregoing section has been to present a systematic account of the fossil fishes known from a definite area of the American Devonic, with occasional notice of related extralimital forms. Distinguishing characteristics have been set forth with considerable fulness, and the descriptions of species follow the usual order of zoological classification. Their more general relationships have been pointed out, and the geological horizon is registered in all cases. An accumulation of details, such as is here brought together, is requisite for the identification of species and for an understanding of the material facts concerning them. We must first have an abundance of actual facts of this nature before it is possible to establish broad generalizations; and to acquire validity, these latter must repose upon the sum total of information now at our disposal in regard to Devonic fishes. Conclusions based upon the fauna of a circumscribed area can not have a wide application or significance unless brought into adjustment with our knowledge of antecedent, contemporary and later faunas, whether from the same geographical province, or from remote quarters of the globe.

There are no other means for attaching significance to a truth except by perceiving its relations to other truths. Thus far we have been concerned principally in assembling, and to some slight extent in correlating recognizable truths; in a word, facts of observation have been brought into orderly array. The next step is to examine them in their bearing upon other known facts, to deduce their general significance, and to assign to the results a commensurate worth in surveying the whole field of paleontological inquiry. The ultimate yield of scientific study is the fruition of philosophical ideas.

To obtain a large perspective of the body of facts at our disposal, it is desirable to marshal them in different ways, and to examine them from different points of view. Their relevancy from a geological standpoint needs consideration, with the object of drawing from them conclusions of geological import. In still larger measure it behooves us to consider 
them as an increment to zoological science, compacting its substantial framework and vastly extending our knowledge of the evolutionary history of organisms. Are we proposing to ourselves an explanation of life, our vision must include not only living matter as we find it today, but also those manifestations of it that existed in the remote past. Side by side with the development of the individual we must examine the evolutionary history of the race. The more we learn of vital processes now operating, the better able are we to understand their operation in times anterior to our own. Comparisons that are enlightening when made between members of the modern fauna may often be profitably extended so as to include members of extinct faunas. Where the time element acts as an impediment to our studies it must be eliminated so far as possible. Zoology of the past does not differ in essence from zoology of the present, any more than ancient history differs fundamentally from modern.

Among other large problems that suggest themselves in reviewing our knowledge of Devonic fishes are those relating to the habits and mode of life of the creatures represented, their adaptation to physical environment, the effects of such adaptation as manifested in their structural modifications and subsequent racial history, and finally the important topics of migration and geographical distribution. All of these issues, though subsidiary to the main theme, offer nevertheless fruitful fields for exploration. It would take us too far astray from the immediate purpose of this paper to consider all of these matters seriatim, particularly as materials are already at hand for those who may wish to pursue them further. For instance, in regard to the habits and mode of existence of ancient forms of fish life, many suggestive hints are contained in the writings of Claypole, ${ }^{x}$ Dollo, ${ }^{2}$ Jaekel, ${ }^{3}$ Kemna ${ }^{4}$ and others.

${ }^{r}$ Several papers in the American Geologist, particularly his posthumous one contained in volume 32 ( 1903 ), under the title, The Dezonian Era in the Ohio Basin.

${ }^{2}$ Recent papers in Bulletin de la Societé Belge de Géologie, etc.

${ }^{3}$ Neue Wirbeltierfunde aus dem Devon von Wildungen. Sitzungsber. Gesellsch. naturforsch. Freunde, no. 3, Jahrg. I 906.

4 Les récentes découvertes de poissons fossiles primitifs. Bul. Soc. Belge. Ig04. I8: $65-78$. 
A large and very important literature exists on the subject of faunal migrations in general, and geographical distribution, which will be referred to later. The question of adaptation to environment has been less fully treated than others in the above category, since, from the nature of the case, our information is more deficient in this respect. The viewpoint, however, is exceedingly instructive, and such light as is obtainable from it is most welcome. That we have not overstated the truth must be clear to all who have gained a right understanding of the working of this principle in analogous cases. As convenient an illustration as any is furnished by human history. One of the notable phenomena in the annals of mankind, and one of the most beneficent in its subtle and far-reaching consequences, is the marvelous civilization attained by the ancient Hellenes. Yet the unfolding and superb blossoming of the flower of Greek genius, together with its rare beauty while it lasted - this surprising spectacle utterly fails of comprehension except as we take account of influences of heredity and environment. To understand Athenian character and habits, or to attempt to account for that civilization which flourished, as Milton says

\section{Where on the Aegean shore a city stands}

Built nobly, pure the air, and light the soil,

it is above all things imperative to understand the conditions of Attic soil and climate. For as soon as one inquires critically into the physical surroundings of the classical Athenian, one discovers that his culture is not primarily dependent upon his peculiar character, but is very largely the resultant of his outward circumstances, and influenced to a marked degree by his climate. One perceives, therefore, that ample justification exists for the following statement, taken from a very readable work on classical antiquity (Tucker's Life in Ancient Athens), with which we will conclude our remarks on this head:

From the bare facts that the Athenian lived in a land which supplied a frugal and simple, but sufficient and wholesome diet, in a climate which makes for sociable outdoor life without producing languor, in an atmosphere which sets off whatsoever things are shapely and beautiful, on a soil furnished with a plentiful supply of excellent material for plastic art - from 
these simple facts should we start before we attempt to understand those ways which characterize what is loosely called his "civilization."

There is yet another way in which we may view the sum total of facts resulting from paleontological inquiry, or even the small part of it which is here brought together. We may seek to interpret our collection of facts from the humanistic standpoint. Granted that this knowledge does not appreciably affect our vital interests, what is it worth to us in other respects? How far does knowledge of this sort tend to enlarge human consciousness? Does reflection upon it tend to vivify our perception of the workings of natural law? And if so, does there not arise from fulness of perception a keener sense of the nobility and dignity of the relation man bears to the wonderful planet he inhabits, and is there not a quicker response on his part to the suggestions which that clarified sense awakens? There can be but one answer to this last question. It is inevitable that there should be a prompt and vigorous response from within when once it is realized that "whatever else man may be, he is the sum of a series of actions linked with all that has gone on before upon this earth." The experience is no less common in paleontology than in other sciences that, after one has gained sufficient insight, ideas and impressions of a certain sort enter our minds, sharpen our vision, and enlarge our mental horizon by elevating us to a summit of observation unattainable before. Possibly there belongs to paleontology an even larger quota of these emancipating conceptions than is true of other sciences, in view of its predominant historical interest - being, as it were, a limitless extension of universal history.

To realize to some extent what the loss of these emancipating conceptions would mean to us, it is only necessary to contrast the olden-time idea of creation with modern evolutionary beliefs. Or, regarding the paleontological record as the continuous unfolding of consciousness, whose beginnings are coeval with the origin of protoplasm, and whose crowning resultant is man, we may picture to ourselves the contracted outlook, the void in our knowledge, and the impoverishment of ideas that would be our portion in case no documents had been preserved to instruct us of the far distant past. 
Imagine our loss were the records of early human history obliterated. What would be our poverty had the grandeur of Rome been dissolved into a mass of meaningless ruins, had the splendid story of Greece and Athens been blotted out, had we remained unconscious that Marathon was ever fought, or that such a one as Socrates had ever lived; had we no line from Homer, no thought from Plato, no inspired word from Palestine vibrating through the ages!

Again let it be said that conceptions of this nature are not foreign to the scope or peculiar province of paleontology. They are, in fact, inherent in all science; they are not mixed with it, but combined with it, and hence do not properly form either its distillate or residuum. If there be any who question how far these ideas are relevant to the study of fossil fishes, we may be allowed to recommend all such to read the lives of Louis Agassiz and Hugh Miller, especially the recent character study of the latter by $\mathrm{Mr}_{\mathrm{r}}$ Mackenzie (I906). An answer is recorded there so plainly that he who runs may read. Wherever the work of Miller is remembered and appreciated, it is not for the value of his discoveries, nor for his contributions to science, but for the native shrewdness, clearness, intensity and discernment with which he drew philosophical conclusions from the study of nature. And his impulse in this direction was first quickened and set in motion by his discovery of fish-bearing nodules in the Old Red sandstone of the north of Scotland. We can not forbear in this connection to quote the following passage from an address delivered a few years ago by M. Albert Gaudry, president of one of the sections of the French Academy : ${ }^{x}$

Quand on passe à Cromarty, dans le Nord de l'Écosse, on aperçoit une colonne érigée en l'honneur de l'ouvrier carrier Hugh Miller; en cassant des pierres, l'ouvrier de Cromarty admirait qu'on y trouvât des créatures fossiles, et il en tirait des pensées si hautes qu'il est devenu un des paléontologistes célèbres de la Grande-Bretagne. Beaucoup de gens sont comme Miller: c'est chose étonnante que l'ardeur avec laquelle, dans tous les pays du monde, on brise les roches pour surprendre les secrets des temps passés: bâtis hier, les Musées de paléontologie sont aujourd'hui trop petits.

Discours à l'Académie des Sciences, tenu le 2 r décembre, 1903. See also the addresses contained in the memorial volume entitled The Centennary of Hugh Miller, printed at Glasgow, 1902. 


\section{ZOOLOGICAL CONCLUSIONS}

In the short space remaining at our disposal we can not dwell further upon these broader, more general topics, and may as well confine ourselves to a brief review of the more obvious zoological and geological considerations resulting from a study of Devonic fishes. Those desirous of consulting a full account of the introduction and succession of the class Fishes, as revealed by the paleontological record, will find this subject adequately treated in the third volume of Zittel's Handbook of Palacontology, and in Smith Woodward's admirable compendium, Outlines of Vertebrate Palaeontology. Other useful works of a more popular character are Dean's Fishes, Living and Fossil, and Jordan's recent comprehensive treatise, A Guide to the Study of Fishes, in two well illustrated volumes. An article aiming to give a recapitulation of the essential facts of paleichthyology is contained in the Annual Report of the New Jersey Geological Survey for 1904, and another dealing with the general principles of piscine evolution, is the presidential address of $\operatorname{Dr}$ A. S. Woodward, ${ }^{x}$ printed in the Proceedings of the Geologists' Association for 1906.

The last mentioned paper is remarkable for its breadth of treatment of several burning problems in the study of fossil fishes, as it is now pursued, attention being called particularly to the following:

I The nature and order of the successive advances in anatomical structure which have suddenly infused new life into the class - the "expression points" as Cope termed them.

2 The new possibilities of development which arose with each successive "expression point."

3 The direction of the various abortive lines of advance and degeneration in each successively higher grade.

The results of such an investigation have obviously the same farreaching significance as those derived from a study of evolutionary series of Cephalopods, to cite only one group of invertebrates that has been pro-

I The Study of Fossil Fishes. Proc. Geol. Ass'n. 1906. 19:266-82. An abstract of this address is given in Nature 1 906. 74:597-99. 
lific in information concerning problems of organic descent. The results have, in the author's opinion, an important bearing on the most fundamental questions concerning "living" matter as contrasted with "dead" matter; for, as stated by Dr Woodward, "we are much more likely to approach some explanation of life by studying the secular development of whole races than by examining the vital processes of individuals or by comparing the members of a single contemporaneous fauna."

A number of concrete illustrations are given in the paper referred to for the purpose of rendering more intelligible the general outcome of paleichthyological study. The range of examples naturally covers all periods, but in the case of Paleozoic fishes, it is doubtful if a better selection could be made for emphasizing the larger lessons to be drawn from our local faunas, and others in eastern North America. For instance, Ostracophores illustrate the principles governing the development of dermal armor; Acanthodian sharks offer suggestive hints concerning the manner in which paired fins originated; Crossopterygians and Dipnoans illustrate the transformation of paired limbs into paddles; and among Chondrosteans, early Paleoniscids enlighten us as to the beginning of effective fins.

An interesting generalization based upon examples occurring among many groups is that all races which do not progress tend to become represented by eel-shaped species in their latter days. We find this to be true of Acanthodians, which declined toward the close of the Paleozoic, and became extinct in the Permian. Their fins, being essentially skin structures, were incapable of the fixation and stiffening by osseus rods after the fashion elaborated by competing groups; hence they gradually became worsted in the struggle, and, as they declined, their changed habits superinduced an altered form of body. Devonic species having the graceful fusiform proportions characteristic of the fleet swimmers become replaced in the Carbonic by unwieldy, overgrown, round bodied creatures like Gyracanthides (text fig. I7, p. 87), that were evidently mud grovelers in land-locked seas and estuaries; and the latest Permian representatives are almost eel-shaped. It is probable also that the extinction of Arthrodires at the close of the 
Devonic was signalized, in some cases at least, by the development of anguilliform types, a very excellent illustration being furnished by one of the three species of Mylostoma referred to on page 149 of this Memoir. ${ }^{x}$ We are confronted, too, in the modern fauna with a scant number of Dipnoan and Crossopterygian survivors which exhibit the usual longbodied or eel-shaped contours of decrepit derelicts.

It will be profitable for us to note some of the instructive examples offered by Smith Woodward for illustrating the development of paired fins, and also those that foreshadow adaptation to a terrestrial habitat. These are among the most important conclusions that can be drawn from the standpoint of comparative anatomy and phylogeny, and inasmuch as they have a direct bearing upon our study of the local fauna, we may allow the author to develop them for us in his own words. The following passage is taken from the presidential address above referred to:

Dawn of paired fins. No link is known between the Ostracoderms (or Ostracophores) just described and the typical fishes which have a lower jaw and paired fins; and it is evident that the latter had already appeared in Silurian times before they possessed a skeleton hard enough to be preserved among fossils. The Silurian and earliest Devonian Acanthodians, however, can not be far from the beginning of these typical fishes, and they seem to show how paired fins began.

These very old Acanthodians are known because they are completely covered by small, hard skin granules like those of the oldest fossilized Ostracoderms. Not only did the armour begin here in the same way as in the Ostracoderms, but there was also an occasional fusion of the skin granules into plates where stiffness was possible or necessary. A few rows of the granules fused together at the front edge of the median fins above and below the body, thus forming cut waters or "spines"; and as a double series of exactly similar "spines" occurs along the lower border of the abdomen where the two pairs of fins are found in later fishes [cf. text fig. i 7 ], it is reasonable to infer that these are likewise the stiffened front edges of fins. In other words, paired fins were not originally restricted to two pairs, but formed a double series along the entire length of the abdomen. Therefore, if the separate median fins were produced by the subdivision of a primitively continuous median membrane along the back and the lower side

A new species, to be described under the name of $\mathrm{Myl}$ os to ma newberryi in a forthcoming number of the Bulletin of the Museum of Comparative Zoology, 50: 224 . 
of the tail, the paired fins arose similarly by the subdivision of continuous membranes which extended as a symmetrical pair along the outside walls of the body cavity. Even in the fashionable Acanthodians of the Silurian and Lower Devonian periods (e.g. Climatius) the foremost and hindmost pairs of spines were somewhat larger than the others; and in all later members of the group the intermediate "spines" dwindled to insignificance (Mesacanthus) or disappeared (Acanthodes), so that only the two normal pairs of fins remained.

Paired fins as paddles. It is, of course, possible that the fins of the Acanthodians were stiffened by some kind of internal cartilage which was never hard enough for fossilization; but this seems improbable, because even the stout arch to which the pectoral fins are fixed is shown by microscopical examination to have been entirely a skin structure, and does not appear to have ensheathed any internal cartilage. There must, however, have been some primitive allies of the Acanthodians with their pairs of fins reduced to the normal two, in which the stiffening was attained by internal rods of cartilage instead of mere skin structures; for a long-bodied (and thus senile) survivor of this allied tribe occurs in the Upper Devonian of Ohio [Cladoselache, text fig. I 4, p. 55]. Here the fin flaps are strengthened inside by a row of simple parallel bars of cartilage, which exhibit a tendency to be squeezed together.

The early fishes which had reached this stage were prepared for further advance. Those which failed to make any progress in their skin skeleton experienced very slight changes in their whole anatomy, and gradually passed into the modern sharks and skates. Those in which the skin skeleton always remained extensive, and soon took the form of symmetrically arranged bony plates and scales, rapidly became developed into the higher fishes which swarm today.

Fin flaps stiffened by internal rods of cartilage are essentially paddles, and could be used for crawling in the mud as well as for ordinary swimming in water. It is therefore interesting to observe that during the Middle and Upper Devonian periods, when four-legged lung breathers must have been just beginning to appear on the land, all the highest fishes had their fins in the shape of paddles. It seems as if at that time there was a general tendency for the fashionable and most advanced fishes to become crawlers rather than swimmers; and there can not be much doubt that the known Crossopterygii, or "fringe-finned ganoids," as these fishes are commonly termed, are the unsuccessful survivors of the race which originally produced the earliest crawling lung breathers or Labyrinthodonts. . . It is one of the problems of paleontology to determine the exact relationships between the paddle-finned fishes and the lung breathers by the discovery of perhaps Lower Devonian links.

As fishes, the Crossopterygii were obviously not a success, for they 
could never be active swimmers, and before the close of the Paleozoic epoch most of them had become extinct. The only widely spread family during the Mesozoic epoch was that of the Coelacanthidae, which became degenerate through having lost some of its head bones and most of its tail; while the sole survivors at the present day are the eel-shaped Polypterus and Calamoichthys found in the fresh waters of Africa. The Coelacanthidae are often quoted as one of the best illustrations of a "persistent type," for they scarcely changed between the Lower Carboniferous and the Upper Chalk. They are, indeed, like most persistent types, organisms in which structural changes took place in the wrong order - not in the order which insured advancement.

The Dipnoi, or paddle-finned fishes, which breathe both by gills and by a modified air bladder (almost a lung), were also especially abundant during the Paleozoic. In having the fundamental part of the upper jaw fused with the skull instead of loosely suspended from it, the Dipnoi agree more closely with the land animals than do the Crossopterygii; but before this feature had been acquired, the roof bones of the skull had subdivided into smaller plates, such as could not have changed into the skull bones of an ordinary Labyrinthodont, while the teeth had clustered into plates, so that they could never have produced the Labyrinthodont dentition. The essential change in the Dipnoan skeleton which led towards the land animals thus occurred too late, after other changes had rendered advance impossible. The result was that with the dawn of the Triassic period the Dipnoi made their nearest possible approach to the higher grade of life in the genus Ceratodus, which still survives almost unchanged in the rivers of Queensland; while the latest members of the group degenerated to mere eel-shaped animals (Lepidosiren and Protopterus), which live in the fresh waters of South America and Africa.

Development of effective fins. The next grade of fishes, the Chondrostei, which specially characterized the Carboniferous and Permian periods, had fins in which the internal cartilages formed only an effective basal support, while the greater part of their expanse was stiffened by flexible skin fibers, which had become "fin rays." Some of these fishes degenerated into eelshaped creatures in the Triassic, Rhaetic and Liassic periods, while others grew to unwieldy proportions and eventually passed into the modern sturgeons. . The median fins became absolutely complete in the Protospondyli, after the upper lobe of the tail had shortened so that the tail fin formed a flexible fan-shaped expansion at the blunt end of the body, while each separate ray in the other median fins was provided with its own definite support. The Protospondyli characterized the Triassic and Jurassic periods, and exhibited endless variety; but their sole survivors at the present day are the long-bodied Lepidosteus and Amia of American fresh waters.

Associated with almost the earliest Protospondyli, there were a few 
precocious fishes which evidently completed their vertebral column at once. This race, including such genera as Pholidophorus and Leptolepis, seems to have temporarily exhausted itself in the effort, for it always occupied a secondary place in the fish faunas until the beginning of the Cretaceous period, when it rapidly multiplied, became fashionable, and replaced the Protospondyli. Thus arose the modern fishes, of the same grade as the herring and salmon, characterized not only by a complete vertebral column, but also by a simplified lower jaw, which consists only of two pieces on each side (w1thout the splenial bone which forms so conspicuous a feature of the earlier fishes). The Isospondyli, as they are termed, being thus provided with a completely bony internal skeleton as well as completed fins, admitted of many more variations than any of their forerunners.

Among fishes, as among other animals, spines characterize only the latest representatives of the class. The Acanthopterygii ("spine-finned") are thus the highest and latest fishes of all, though they sometimes eventually descend from their high estate by degeneration. They exhibit all the peculiar changes in the skull, upper jaw, and pelvic fins noticed at first appearing in a variable manner in the Cretaceous Isospondyli. . . The spiny-finned fishes began by Berycoids and possibly Scombroids in the Chalk, closely resembling, but not identical with genera living at the present day. By the Eocene period, however, nearly all the modern groups of Acanthopterygii had become completely separated and developed, and their sudden appearance is as mysterious as that of the early Eocene Mammalia.

\section{GEOLOGICAL CONCLUSIONS}

It will be convenient to include under this head certain topics whose practical bearing is of chief interest to the geologist, although the evidence involved is partly zoological, and in still larger part geographical, or paleogeographical. We refer to such matters as relate to the areal and vertical distribution of Devonic fish life, the dispersion of new types and varieties, migration, succession and occasional recurrence of faunas, and indications furnished by the fossils themselves in regard to climatal and physical conditions, either those of local nature, or others prevailing over wide areas. Thus, by way of illustration, we are able to affirm from the general complexion of ancient faunas, that the climate of arctic regions was notably warmer during the Devonic and late Paleozoic than at subsequent periods. We are in possession, also, of a large fund of evidence regarding migrational movements, and can delineate with great exactitude a number of 
physical barriers that were interposed to lines of migration. Means are at hand in very many cases for distinguishing between free swimming inhabitants of the open sea and other forms whose structural organization proves them to have been bottom feeders, mud grovelers, or frequenters of estuaries and fresh-water lagoons. Manifestly inferences of this nature are of far-reaching geological significance, besides having a direct practical application. Finally, a knowledge of the relations of successive vertebrate faunas is an important corollary to the information we have concerning fossil invertebrate faunas, the two categories being mutually complementary, and taken together are essential to a natural classification of geologic formations.

We may consider first some of the more general conclusions derived from a study of the distribution of Devonic fishes, having special reference to those of New Ycrk State. In the first place it is necessary to bear in mind that the Devonic faunas of the interior of North America announce themselves as belonging to two distinct types, one being more or less confined to the eastern, and the other to the west central United States and Canada. Or, to put it differently, it is possible to recognize within the interior of our continent two more or less distinct geological provinces of the Devonic, differing from each other and from the more remote areas lying to the westward (Cordilleran and continental border provinces) in their respective faunal characteristics. The eastern interior province, which has received the name of Appalachian, is typically represented in New York State, but extends westward into Ontario and Michigan, and southwestward into the Ohio valley region, forming circumscribed areas known as the Cumberland and Indiana basins. The western interior province is represented typically in Iowa, and was more or less effectively separated from the eastern during early and Middle Devonic time. Its limits are coextensive with the so called Dakota sea, which was open to the northwest during the mid-Devonic through Manitoba, the Mackenzie Basin, and across Behring straits into Siberia, but was probably closed to the northeast. The suggestion has been made, and indeed been received with some favor, that 
intercommunication existed during the mid-Devonic between the typical lowan and Eurasian faunas by means of a northeasterly passageway through Manitoba, Hudson and James bays, Greenland, Spitzbergen and circumpolar regions. ${ }^{x}$ More recently, however, weighty objections have been opposed to this theory, and it has been asserted very emphatically by Professor Schuchert ${ }^{2}$ that there is not the slightest reason to connect the Hudson and James Bay Devonic with that of the Dakota sea (or western intercontinental province). It is further denied by the same author that this latter province was in connection with a southern ocean, extending into Brazil, until Hamilton time. On the other hand students are agreed that communication was maintained between the Appalachian province and that of the southern hemisphere during the mid-Devonic. Concerning the pathways that were open between the Appalachian and Eurasian provinces during the Middle and later Devonic there are still some differences of opinion.

It will be observed accordingly, that the Devonic in this country was preeminently an era of provincial development of marine faunas. Furthermore it appears that diversity in this respect is more strongly marked in

IWeller, S. Composition, Origin and Relationships of the Corniferous Fauna in the Appalachian Province of North America. Jour. Geol. rgo2. ro: 423-32. Compare also an earlier paper by the same author on interpretation of Silurian faunas. Jour. Geol. I 898 . 6:692-703. This theory is adopted by L. Hussakof in explaining the distribution of Devonic fishes. Cf. Amer. Mus. Nat. Hist. Mem. 1906. 9: I37.

${ }^{2}$ Schuchert, C. On the Faunal Provinces of the Middle Devonic of America, etc. Amer. Geol. r 903. 32: 137-62; Ulrich, E. O. \& Schuchert, C. Paleozoic Seas and Barriers in Eastern North America. N. Y. State Mus. Bul. 52. r9o2. p. 633-63. Among other suggestive papers dealing with faunas and provinces and migrations during the Devonic one may consult the following by Dr J. M. Clarke: Outline of the Geological Succession in Ontario County. N. Y. State Geol. 4th An. Rep't I884. (1885) p. 9-22; The Hercynian Question. Ibid. 8th An. Rep't I888. (1889) p. 6I-9I; The Stratigraphic and Faunal Relations of the Oneonta Sandstone etc. Ibid. I5th An. Rep't r895. (1897) r: 31-8r; The Naples Fauna in Western New York. pt I. Ibid. 16th An. Rep't r896. (1899) p. 29-162; pt 2. N. Y. State Mus. Mem.6. I904. p. 199-454; Marcellus Limestone oi Central and Western New York. N. Y. State Mus. Bul. 49. rgor. p. II5-38; Indigene and Alien Faunas of the New York Devonic. N. Y. State Mus. Bul. 52. I902. p. $66_{4}-84$. 
the Appalachian region, where there were varying conditions of sedimentary deposition, than in the Cordilleran and continental border regions, where these conditions were more uniform. Thus, in the eastern province, as Professor Williams has pointed out, diversity and alternation of deposits is accompanied by numerous successive and distinct faunas; in the extreme western regions, uniformity of prevailing calcareous sedimentation for long periods is characterized by the abnormally long continuance of many Devonic species; and the central continental province, midway between the two, is marked by the unmistakable recurrence of Devonic species well along into the Carbonic. Another noteworthy feature of the Devonic which has been developed very fully and clearly by the painstaking investigation of Dr Clarke is that faunal changes within the ancient Appalachian sea are sometimes so precisely indicated that it is possible, as in the case of the Portage group, to trace the boundaries not only of local provinces, but of local subprovinces characterizing the stage in question. Thus, the Genesee province of the Portage is divided into Chautauquan and Naples subprovinces on the basis of differences in their faunal facies; and an interesting peculiarity of the Naples subprovince is that, as stated by Dr Clarke, "with contemporaneous faunas of the Appalachian gulf" its fauna "has in its purity no organic relation, direct or sequential."

It is very necessary to understand this matter of the provincial character of Devonic faunas in North America. Also, in tabulating the facts of distribution, one must keep in mind the inferred lines of intercommunication between those provinces that were connected, as well as the position of barriers between others that are known to have been separated. The data upon which our information in regard to these matters reposes have been brought together chiefly by workers in invertebrate paleontology, and as the evidence at their disposal is enormous as compared with that obtained from a study of the vertebrates alone, no deductions drawn from the latter are likely to prejudice the results depending upon a different class

I Clarke, J. M. The Naples Fauna in Western New York. N. Y. State Mus. Mem, 6. 1904. p. $3^{82 .}$ 
of remains. In point of fact, no discoveries of fossil fishes have yet been made which tend to contradict or discredit conclusions already established on the basis of fossil invertebrate evidence. The known distribution of the former is in all respects consonant with, and one is tempted to add, confirmatory of the principles that have been formulated from a study of the latter. We find simply that the more mobile free-swimming contingent of Devonic faunas followed the same routes and penetrated, probably with greater facility, into the same areas as the slower moving invertebrate associates of the original fauna, wherever we are able to trace its migrations.

Nevertheless, some facts relating to the distribution of Devonic vertebrates stand out with such distinctness as to attract particular attention. The earlier Devonic horizons in New York State are singularly deficient in fish remains, and the faunas that appear successively in the Meso- and Neodevonic are introduced with little or no foreshadowing, save that the members of the Hamilton fish fauna are largely a residuum or evolution product of the preceding Onondaga congeries. Clearly, however, the Mesodevonic fish faunas are not indigenous in the Appalachian basin, for we meet with practically the same assemblage in rocks of equivalent age elsewhere, as for instance, in the Eifel district (Calceola beds) and Bohemia (étages $\mathrm{F}^{2}$ and $\mathrm{G}^{\mathrm{x}}-\mathrm{G}^{3}$ ) ; and besides, the Oriskanian fauna contains no elements, so far as known, out of which the Onondaga might have developed. The vertebrate portion of the latter is, therefore, quite unmistakably an immigrant fauna. That it did not come in from the northeast may be asserted with equal confidence, for none of its members are represented in the maritime provinces of eastern North America, nor indeed, in the Lower Old Red sandstone of North Britain, Greenland or Spitzbergen. As in the case of the majority of invertebrates, ${ }^{x}$ the Onondaga fish fauna came in from the west, and in course of time very probably withdrew westward, many of its characteristics persisting into the Hamilton of the western interior province.

${ }^{3}$ Clarke, J. M. Indigene and Alien Faunas of the New York Devonic. N. Y. State Mus. Bul. 52. Ig02. p. 668. 
The Hamilton piscine fauna is so obviously the descendant of the preceding Onondaga, and these two together have so much in common with the Eifelian, Bohemian and Russian Mesodevonic, as to confirm in the strongest possible manner the contention of Professors Clarke and Schuchert that the Ulsterian and Erian should be recognized as divisions of the Middle Devonic.

Attention has been called by Professor Schuchert to the similarity between the Middle Devonic fauna of the Hudson Bay region, and that of the Mississippian Onondaga. A number of considerations are proffered to show that while each of these faunas has its individual facies, yet both are of that type which characterizes the American, in contradistinction to the Eurasian province; and moreover, they differ both in horizon and facies from the Stringocephalus zone of western and northwestern Canada. It is inferred, accordingly, that the Hudson Bay Devonic area was entirely shut off from communication with the Dakota sea, but on the other hand it is thought probable that intermittent connection existed between the former basin and the Mississippian sea. An opening is also posited by the same writer, lasting throughout the Devonic, between the Appalachian and Eurasian provinces, the route leading through the so called Connecticut straits, thence along the Gulf of St Lawrence and across the Atlantic. Having established what seems to him a reasonable basis for the propositions just stated, Professor Schuchert sums up his conclusions in regard to Middle Devonic faunal distribution in the following paragraph:

The Onondaga fauna is the outgrowth of the Oriskanian fauna of the North Atlantic type plus the migration during Onondaga time of other North Atlantic forms by way of the Connecticut trough and invasions from the far south through the Indiana basin. The Hamilton fauna is the descendant of that of the Onondaga plus North European migrants by way of the Connecticut trough, South American arrivals by way of the Indiana basin, and slight invasions from the Dakota sea by way of Traverse straits. These three openings then remained in existence during the greater part of Upper Devonic time. ${ }^{\mathrm{x}}$

I On the Faunal Provinces of the Middle Devonic of America etc. Amer. Geol. 19०3: $32: 156-162$. 
This rather full statement in regard to conceptual waterways has been made not for the purpose of criticism, but in order to synthesize as far as possible certain elements of apparently conflicting nature. The test of a sound judgment is its ability to unify various and sometimes even dissonant concepts. In the present instance it becomes necessary to reconcile with the evidence furnished by Helderbergian and Oriskanian invertebrates in favor of an invasion from the northeast, certain other evidence that appears at first sight discordant, namely, the failure of any Lower Devonic vertebrates to take part in the migration. As will be seen from an inspection of the faunal lists given on pages I 3 and I4, the abundant and rather diversified fish fauna occurring in the synclinal basin of the Restigouche near Campbellton, N. B., is without a single representative in rocks of Lower or Middle Devonic age in the Appalachian province. No traits are observed in the Onondaga or Hamilton fish faunas which can be ascribed to an immigration from eastern Canada by way of the putative water route called by Clarke the "Appalachian strait," and by Dana the "Connecticut trough," which is supposed to have been open during the late Siluric and greater part of the Devonic. None of the Appalachian Mesodevonic vertebrates can be regarded as the genetic descendant of forms that existed at an earlier period in the maritime provinces in eastern North America. The problem is to reconcile this diversity of evidence without contradiction, and it is believed that a solvent will be found in Dr Clarke's recent determination of the Gaspé sandstones as of later than Oriskanian age.

In his sketch of the geology of Percé, published in 1904, Dr Clarke declared that the fairly rich marine fauna of the lower beds about Gaspé basin reveals evidence of both early and late Devonic age, and that the prevailing sedimentation is of the same aspect as characterizes both in New York and Europe the deposits of the Devonic or Old Red lakes and lagoons. ${ }^{x}$ This preliminary statement strikes at the root of the whole matter, and sounds the keynote of an interpretation which has since been

'Percé, a Brief Sketch of its Geology. N. Y. State Mus. Bul. 8o. I 1904. p. 142. 
more fully evaluated by the skilful New York State Geologist. The results of his extended investigation of the invertebrate paleontology of the Gaspé Devonic remain as yet unpublished, but an idea of their general import may be gathered from the following extract from a private communication, which we are enabled to present here through the courtesy of Dr Clarke:

The profusion of evidence that has been obtained from a study of invertebrate paleontology seems indubitably to indicate that the Gaspé sandstones are not of the geological age assigned to them by Logan and the Canadian geologists generally. That is to say, they are not Oriskanian, for, though they contain certain Oriskany species, these are the survivors of the earlier limestone faunas of that region persisting during the incursion of a distinctively Hamilton Lamellibranch and Brachiopod fauna from the southwest.

Dawson subdivided the Gaspé sandstone into three parts: the lower division coordinated with the Oriskany and Onondaga; the middle, equivalent to the Hamilton group; and an upper conceived to be equivalent to the Chemung. This entirely arbitrary subdivision was based upon the distribution of the terrestrial flora, and is not, I think, in any way borne out by the present evidence. The weakness of the comparison lies in the attempt to correlate with true marine deposits the very heavy mantle of sands of telluric, delta or lagoon origin conformable in every way physiographically to the Old Red deposits elsewhere, the few marine fossils which it contains being the accumulation of overwash from outside during times of stress. Ells and Low have suggested the probability that the fish-bearing beds at Scaumenac and Campbellton were laid down in an area separated from the more northerly region by barriers of old land, and in my judgment this is an entirely probable condition, not eliminating the possibility of connection between the two basins at some point further westward.

Indeed, as early as I 883 , it was noted by R. W. Ells that a number of invertebrate fossils from the northern limit of the Gaspé Devonic were

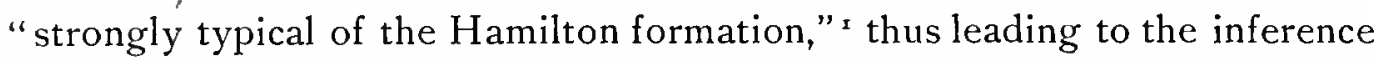
that "the Gaspé sandstone series, of the coast, is probably of the same age, though the absence of typical shells in a large portion of it makes their separation more difficult." The same author had previously described the beds at Campbellton, N. B., before they were found to contain fish remains, and had pronounced upon their equivalence with the lower

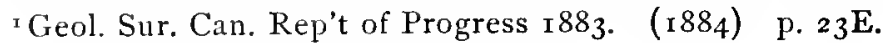


part of the Gaspé sandstones. ${ }^{x}$ This opinion was based upon evidence of paleobotany, and, having been confirmed a few years afterward by J. W. Dawson, ${ }^{2}$ is now generally accepted. Indeed, Logan seems to have entertained similar views as early as 1863 [Geol. Can. p. 450]. As for the plant and fish bearing beds at Scaumenac bay, on the Quebec side of the Restigouche, these are asserted by Dawson to be "no doubt the equivalents and continuation of the upper part of the Gaspé sandstones." In the absence of a more precise indication of their age, these beds are commonly referred to as Upper Devonic, and their vertebrate content favors that conclusion.

In the light of Dr Clarke's coordination of the Gaspé sandstone series with rocks of Postoriskanian age, we are no longer required to look in that direction, nor to the probably contemporaneous Campbellton fauna for the origin of the Onondaga fish fauna found in New York State. On the other hand it may be conceded as rather more likely that there was some movement among vertebrate organisms in the reverse direction, for such an hypothesis would account for the presence of a typical Onondaga species, $\mathrm{M}$ a chaeracanthus sulcatus, at different levels in the Gaspé series (Logan's Divisions I and 6). ${ }^{3}$ The genus Cephalaspis is common to both the Gaspé series and Campbellton beds; and together with the majority of forms from the latter horizon is indicative of Old Red sandstone conditions. ${ }^{4}$

Reverting now to the Hudson Bay Middle Devonic fauna, we find that, as listed by Whiteaves, it is unmistakably of about the same age as the Onondaga. According to Schuchert, its faunal facies "is more that of the Mississippian type than any other known in America." This similarity

I Ibid, Rep't of Progress 1879-80. p. 1o $D-14 D$.

2Dawson, J. W. The Fossil Plants of the Erian (Devonian) and Upper Silurian Formations of Canada. Geol. Sur. Can. pt 2. I882. p. 49.

3Geol. Can. I863. p. 395; Palaeozoic Fossils. I874. pt I, 2:3, 4. Lankester, E. R. Geol. Mag. I870. 7:398, fig. 3.

4 Concerning the supposed evidence of Cephalaspis from the Lower Old Red sandstone series of Spitzbergen, see Smith Woodward's paper on "The Devonian Fish-fauna of Spitzbergen," in Ann. \& Mag. Nat. Hist. I8gr. (6) 8:3. 
is therefore held to indicate that there was at least intermittent connection between the two basins during Onondaga time, and persisting well into the Hamilton. It is admitted, however, that the question as to how the stream of migration entered the Hudson Bay area during the Middle Devonic is not so easy to answer." Precisely at this point some light is thrown on the problem by vertebrate paleontology. A number of specimens of Macropetalichthys sullivanti ( $=$ M. rapheidolabis) are recorded by Bell and Whiteaves from the country immediately west and south of Hudson and James bays. ${ }^{2}$ This exclusively Onondaga species ( $\mathrm{Mr}$ Schuchert inadvertently calls it a Hamilton fossil) is most abundant in Ohio and Indiana, and decidedly less common in New York State. The same genus, represented by some two or three species, occurs also in the Eifelian Devonic, which is equivalent practically to the Onondaga, and in the slightly earlier horizon in Bohemia designated as étage $G^{x}$. No trace of it occurs, however, in the Mesodevonic of the maritime provinces of eastern North America. One may readily infer that this genus and its various associates are indigene in Bohemia, a part of the vertebrate fauna from étage $\mathrm{G}^{\mathrm{x}}$ being inceptive in étage $F^{2}$. Thence it spread northeastward into Russia, westward into the Eifel District, and northwestward into the Hudson and James Bay region. From this latter region we may suppose it to have passed southward through Ontario by means of a passageway connecting with the Appalachian gulf over the area that is now occupied by Ohio and Indiana, where the fauna reached its climacteric. The most conspicuous elements of the fauna are Arthrodires and Ptyctodonts, groups which began immediately upon their introduction to attain a most remarkable development. Throughout the Hamilton and later Devonic, conditions must have been eminently favorable in the Appalachian sea for the further specialization of armor-clad Dipnoans of the type represented by Dinichthys and its congeners. Like their earliest predecessors, they became of greatest importance locally in Ohio.

Loc. cit. p. ${ }^{5} 6$.

${ }^{2}$ Geol. Sur. Can. Rep't of Progress. I875-76. p. 3 I9. 
A glance at the following table will suffice to show the close correspondence, as regards at least their vertebrate contents, between the Appalachian Mesodevonic and equivalent horizons of eastern Canada and central Europe.

\section{FAUNAL LIST SHOWING DISTRIBUTION OF MIDDLE DEVONIC FOSSIL FISHES}

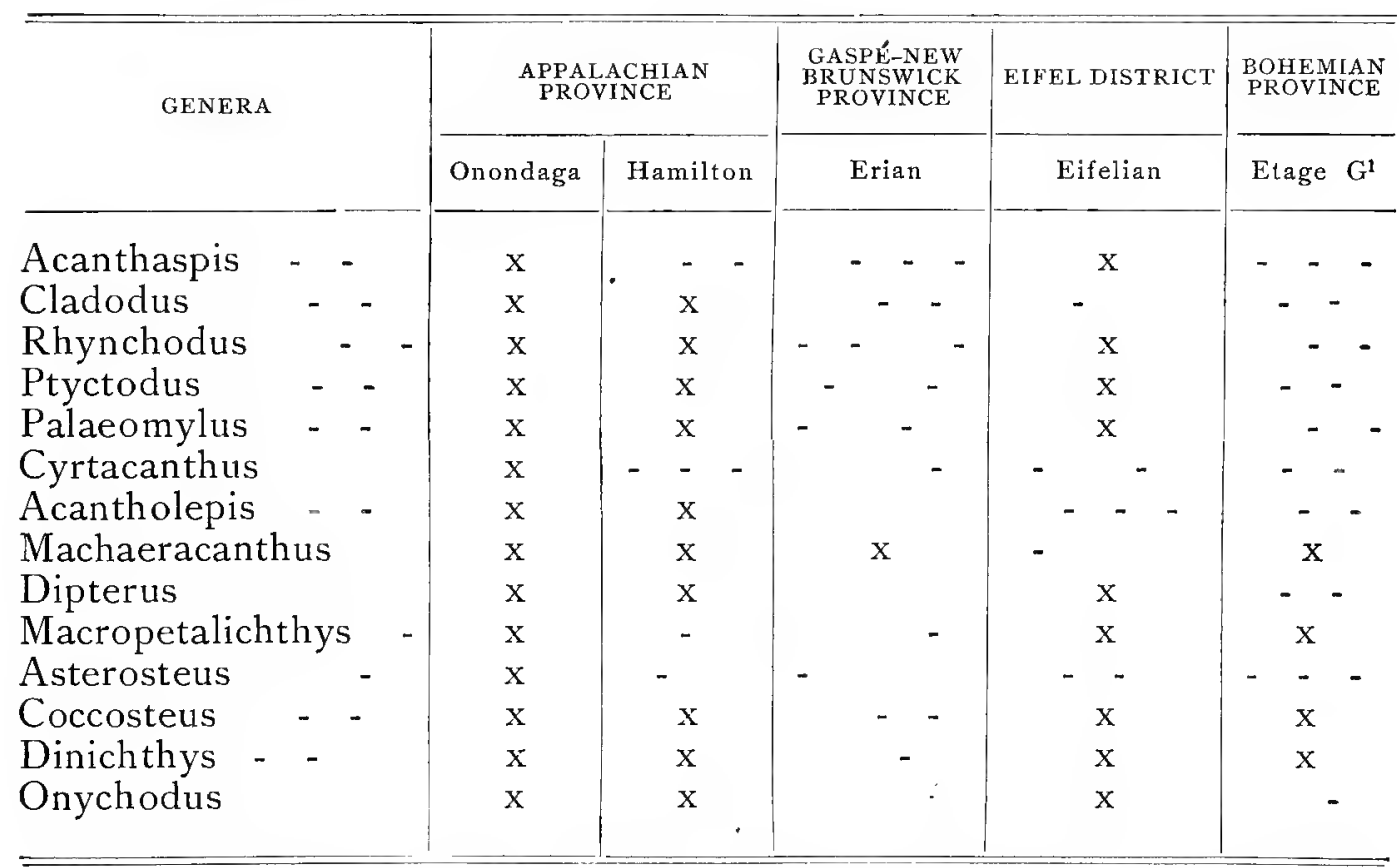

Note added during correction of the proof. Of the genera enumerated in the above list, Acanthaspis occurs also in the Lower, and Onychodus in the Upper Devonic of Spitzbergen, but none have been reported from the Upper Devonic of East Greenland.

According to a recent communication by Dr O. Jaekel [Sitzber. Ges. Naturf Freunde, rgo6], it appears probable that the scalelike dermal plates referred to Ptyctodus on page 73 of this memoir, and illustrated in plate $\mathrm{r}$, figure 6, properly belong to Rhynchodus. They can not possibly, however, be regarded as internal structures, or in the nature of a pectoral girdle, the extensive series of American specimens with which we are familiar being clearly irreconcilable with such an interpretation, Sufficient reason has not yet been shown for doubting the chimaeroid affinities of Ptyctodonts. 

EXPLANATION OF PLATES

PLATE $r$

$\mathrm{r} 95$ 


\section{Apedodus priscus Leidy}

I Detached crown. $\quad$. 2

Page 166

2 Detached crown. $\times 2$

Chemung beds; Warren, $\mathrm{Pa}$.

Onychodus $\mathrm{sp}$. indes.

cf. O. sigm oides Newb.

Page 169

3 Imperfect slightly arcuate tooth showing central cavity. $x_{2}$ Hamilton limestone; Milwaukee, Wis.

Onychodus sp. indes.

Page 160

4 Detached presymphysial tooth. Cross-section of base of crown shown at the right. Natural size

Middle Devonic; Eifel district, Germany

Original in Museum of Comparative Zoology, Cambridge, Mass.

Cladodus monroei Eastm.

Page $6 z$

5 Detached tooth, coronal apex and portion of the root broken away. $\quad x$ Hamilton limestone; Milwaukee, Wis.

\section{Rhynchodus sp.}

Page 33

6 Detached scalelike plate evidently external in position, and regarded as a dermal calcification of Rhynchodus. Natural size

Hamilton limestone; Milwaukee, Wis.

Similar detached plates are abundant also in the Cedar Valley limestone of Iowa, and in the Upper Devonic of Wildungen, in Rhenish Prussia.

\section{Diplodus priscus Eastm.}

Page 59

7 Detached tooth, anterior face. $\times 4$

8 Detached tooth, anterior face. $\times 4$

Upper Devonic; Elmhurst, Ill.

\section{Coccosteus sp.}

Page 115

9 Detached dorsomedian plate. Natural size

Onondaga limestone, Clifton Springs, N. Y. 


\section{FISHES}

Memoir 10. N. Y. State Museum.

Plate 1
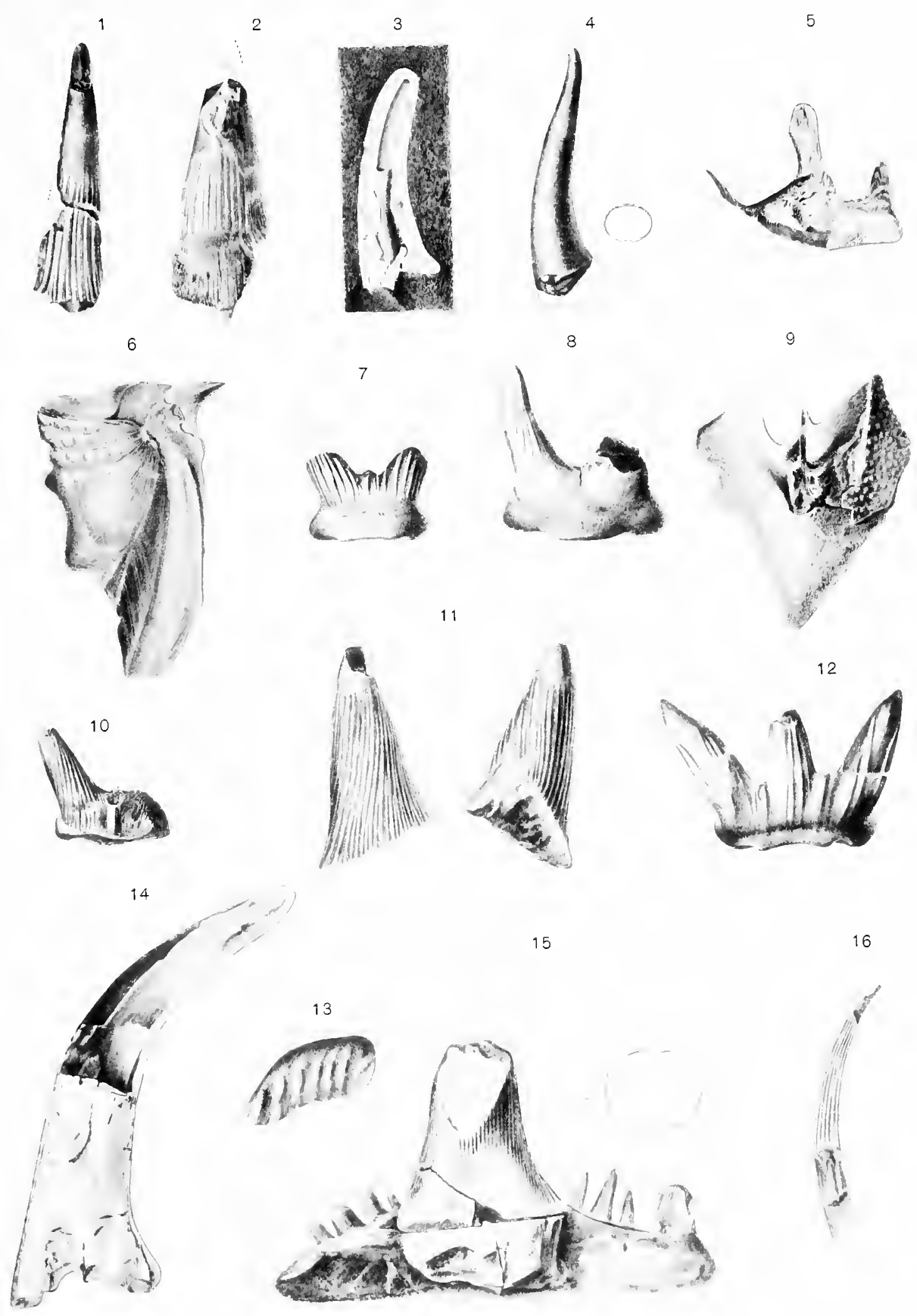



\section{Diplodus striatus Eastm. \\ Page 6o}

Io Detached tooth, anterior face. $\times 4$

I A Anterior and posterior aspect of large detached cone. $\quad$ x 4

Upper Devonic ; Elmhurst, Ill.

Phoebodus politus Newb.

Page 6o

I 2 Detached tooth, anterior face. $\times 4$

Cleveland shale; Lorain county, $O$.

Original in Museum of Comparative Zoology, Cambridge, Mass.

\section{Sagenodus sp.}

Page 160

I3 Detached dental plate, of the form usually referred to Sagenodus, showing extreme effects of abrasion. Natural size

Chemung beds; Warren, Pa.

Onychodus hopkinsi Newb.

(See plates 3 and 9)

Page 169

I4 Detached tooth, falcate, but not sigmoidal; dentine eroded. $\times 3 / 2$

Chemung beds; Franklin, N. Y.

Original in New York State Museum

Cladodus prototypus sp. nov.

Page 6x

I5 Detached tooth, posterior face. Coronal cross-section shown at the right. Natural size

Columbus limestone; near Columbus, O.

Original in American Museum of Natural History, New York. (Cat. no. 4257 , olim James Hall coll.)

\section{Homacanthus acinaciformis Eastm.}

Page 75

I6 Dorsal fin spine. $\times 3 / 2$

Chemung beds; Warren, Pa.

Original in Museum of Comparative Zoology, Cambridge, Mass. 


\section{PLATE 2 \\ Dipnoan dental plate \\ Page ${ }^{6} 6_{4}$}

I Dental plate of undescribed Dipterine genus, with obsolescent tubercular ridges. Natural size

Upper Devonic (State Quarry beds); Johnson county, Ia.

Original in Museum of Comparative Zoology, Cambridge, Mass.

Acanthaspis armata Newb.

Page 117

2 Supposed antero-ventrolateral plate with fixed spinous process; ornamentation indicating a young individual. Natural size

Columbus limestone; Sandusky, O.

Original in Museum of Comparative Zoology, Cambridge, Mass.

\section{Undetermined Arthrodire \\ Page r57}

3 Dorsomedian plate of undetermined Arthrodire. $\times 2$

Hamilton limestone; Milwaukee, $\mathrm{W}$ is.

Original in private collection of E. E. Teller, Milwaukee, Wis.

4 Detached dorsomedian plate comparable to that shown in figure 3, and from same horizon and locality. $\mathrm{x}_{2}$

Original in private collection of E. E. Teller, Milwaukee, Wis.

Rhynchodus pertenuis Eastm.

Page 69

5 Anterior portion of lower dental plate. Natural size

Chemung beds of Franklin, Delaware co., N. Y.

Original in New York State Museum.

5a Cross-section of same taken along line of fracture, shown immediately below

Dinichthys pustulosus Eastm.

(See plates 5 and 12 )

Page 130

6 Left posterior palato-pterygoid dental plate, or "shear tooth." Natural size

Hamilton limestone; Milwaukee, Wis.

Original in private collection of E. E. Teller 


\section{FISHES}

Memoir 10. N. Y. State Museum.

Plate 2

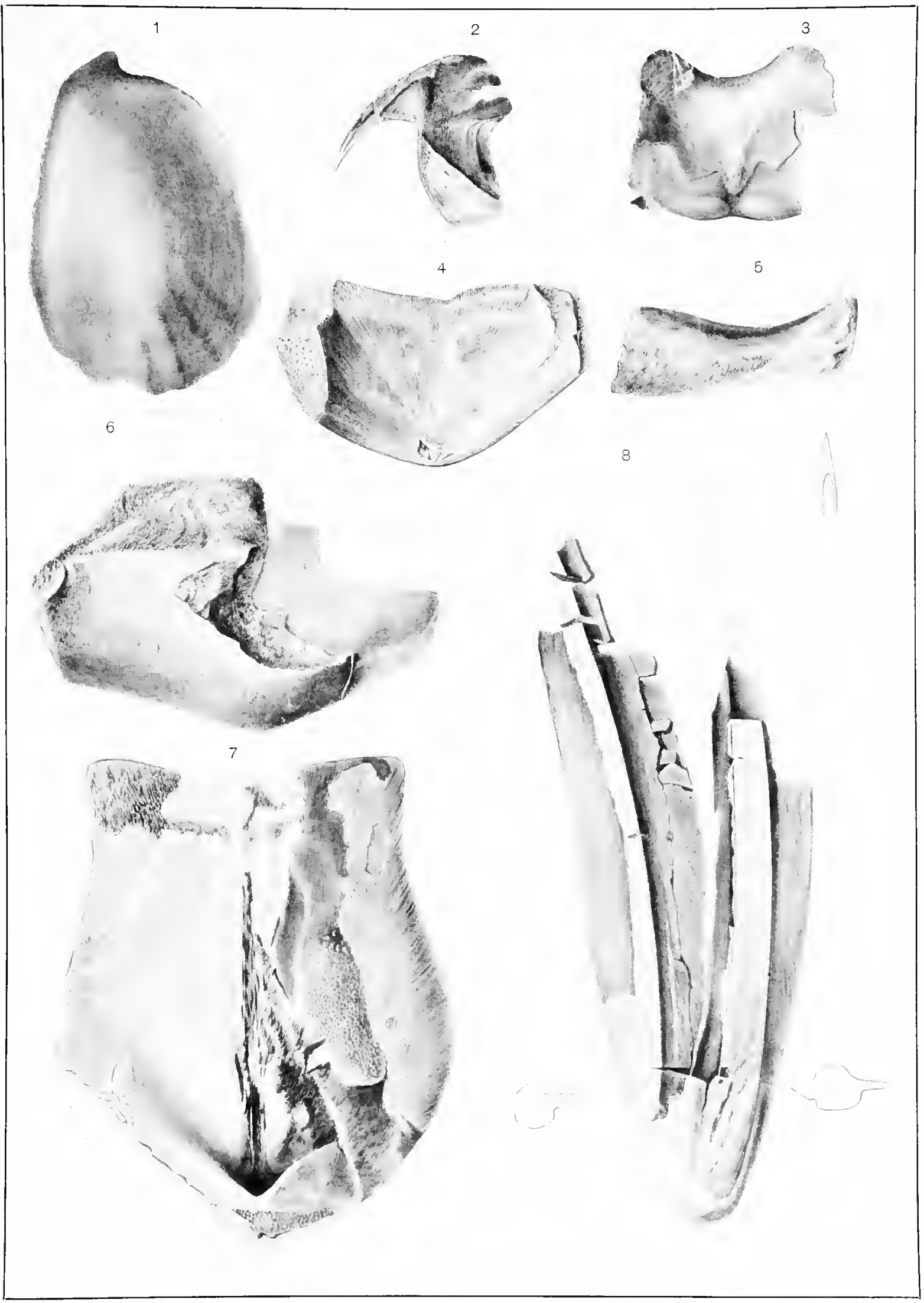





\section{Dinichthys halmodeus (Clarke)}

(See plate 10)

Page $\mathbf{x} 6$

7 Dorsomedian plate. Natural size. Superficial ornament partially denuded, and inferior carina exposed.

Marcellus shale, Livonia salt shaft, N. Y.

The original, found in natural association with the type cranium, is preserved with it in the New York State Museum.

Machaeracanthus longaevus sp. nov

Page 85

8 Right and left pectoral fin spines preserved in natural association. $x^{2} / 3$. Cross-sections of middle portion of either spine shown at the sides.

Trilobite bed of the Lower Hamilton, shore of Lake Erie near mouth of Eighteen Mile creek

Original in Buffalo Society of Natural History 


\section{PLATE 3}

\section{Acantholepis fragilis Newb.}

$$
\text { Page } 79
$$

I Drawing from squeeze of impression. Natural size

Ithaca beds, near Truxton, Cortland co., N. Y.

Original in New York State Museum

2 Detached scale. $\mathrm{x}_{2}$

\section{Onychodus (sigmoides ?)}

Marcellus shale; Oran, Onondaga co., N. Y.

Original in New York State Museum

Onychodus hopkinsi Newb.

(See plates $I$ and 9 )

Page r69

3 Series of five presymphysial teeth. Natural size

Chemung beds, Franklin, N. Y.

Original in New York State Museum

\section{Bothriolepis nitida Leidy}

$$
\text { (Ses plate } 7 \text { ) }
$$

4 Terminal portion of "arm"; sutures between brachial plates obliterated. Natural size

Chemung beds; Franklin, N. Y.

Original in New York State Museum

\section{Apateacanthus vetustus (Clarke)}

\section{Page 8I}

5 Original specimen refigured. Natural size. Drawing from squeeze in New York State Museum.

Portage (Naples) beds; near Milo, Yates co., N. Y.

Machaeracanthus sulcatus Newb.

Page $8_{4}$

6 Redrawing of holotype figured by Hall in Report on the Fourth District, page 174 , figure 69. Natural size Onondaga limestone; Victor, Ontario co., N. Y.

Original in New York State Museum 


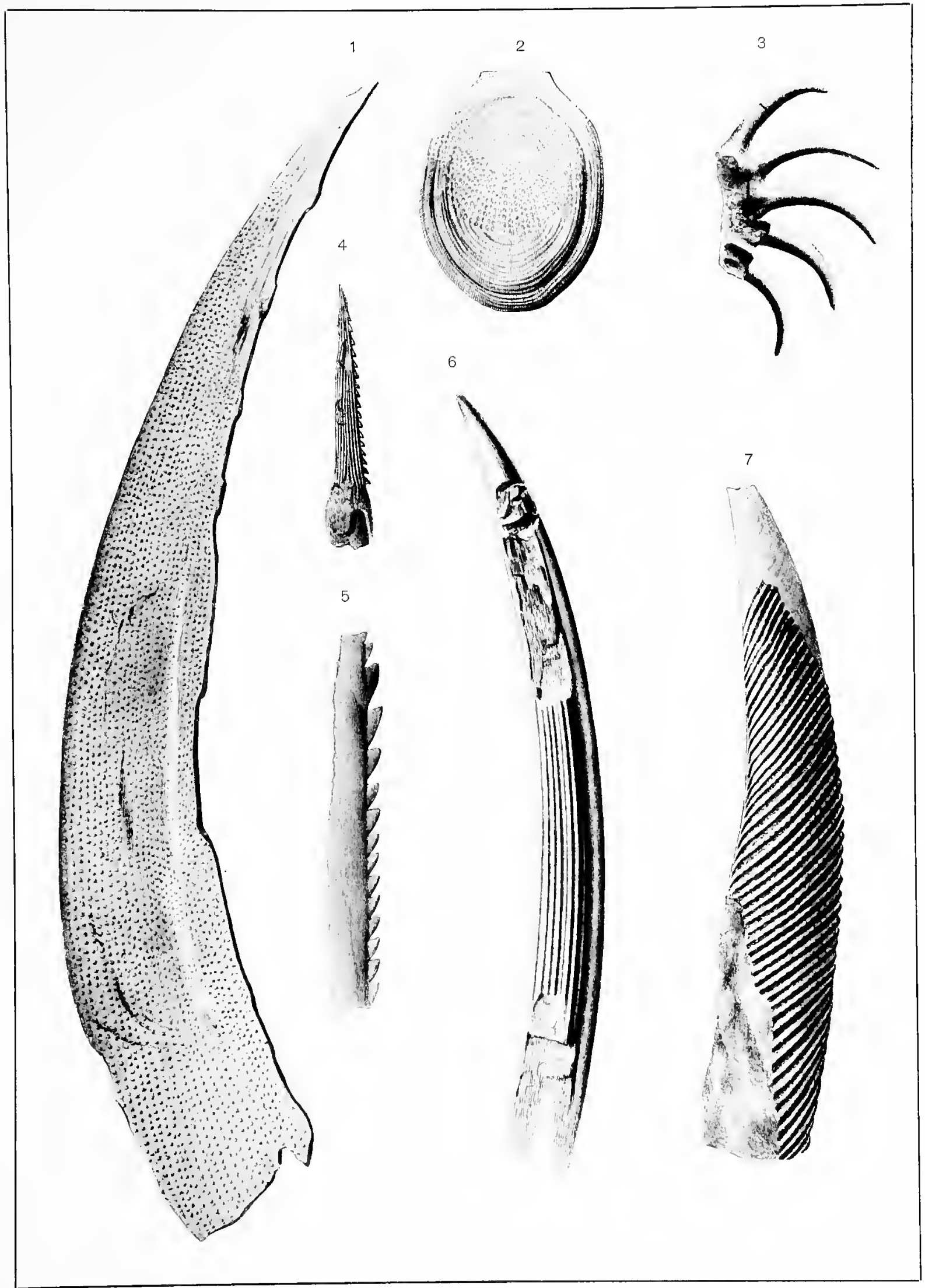



Gyracanthus sherwoodi Newb.

$$
\text { Page } 87
$$

7 Drawing from squeeze of spine. Natural size

Chemung beds; found loose in Ischua township, Cattaraugus co., N. Y.

Original in New York State Museum

Compare with restoration of Gyracanthides shown in text figure $\mathbf{I}$, page 87 .

201 
PLATE +

Dipterus calvini Eastm.

Page 160

I Right mandibular plate. Natural size

Cedar Valley limestone (Middle Devonic) ; Fairport, Ia.

Original in Museum of Comparative Zoology, Cambridge, Mass.

Dipterus sp. nov.

Page 164

2 Left mandibular dental plate. Natural size

State Quarry beds (Upper Devonic) ; Nort'. Liberty, Johnson co., Ia.

Original in Museum of Comparative Zoology, Cambridge, Mass.

Dipterus uddeni Eastm.

Page 160

3 Left mandibular dental plate. Natural size

Base of Cedar Valley limestone (Middle Devonic); New Buffalo, Ia.

Original in Museum of Comparative Zoology, Cambridge, Mass.

4 Lateral aspect of same specimen as shown in figure 3

Dipterus mordax Eastm.

Page $16 \mathrm{r}$

5 Right mandibular dental plate. Natural size

State Quarry beds (Upper Devonic); North Liberty, Johnson co., Ia.

Original in Museum of Comparative Zoology, Cambridge, Mass.

6 A worn specimen from same horizon and locality as the last. Natural size

Dipterus sp. nov.

Page 164

7 Palatal dental plate of undescribed species. Natural size. The functional surface is in reality more concave than is here represented.

From same horizon and locality as the original of figure 5

Dipterus sp. nov.

Page 164

8 Palatal dental plate of undescribed Dipterine species. Natural size State Quarry beds (Upper Devonic); North Liberty, Johnson co., Ia. Original in Museum of Comparative Zoology, Cambridge, Mass. 


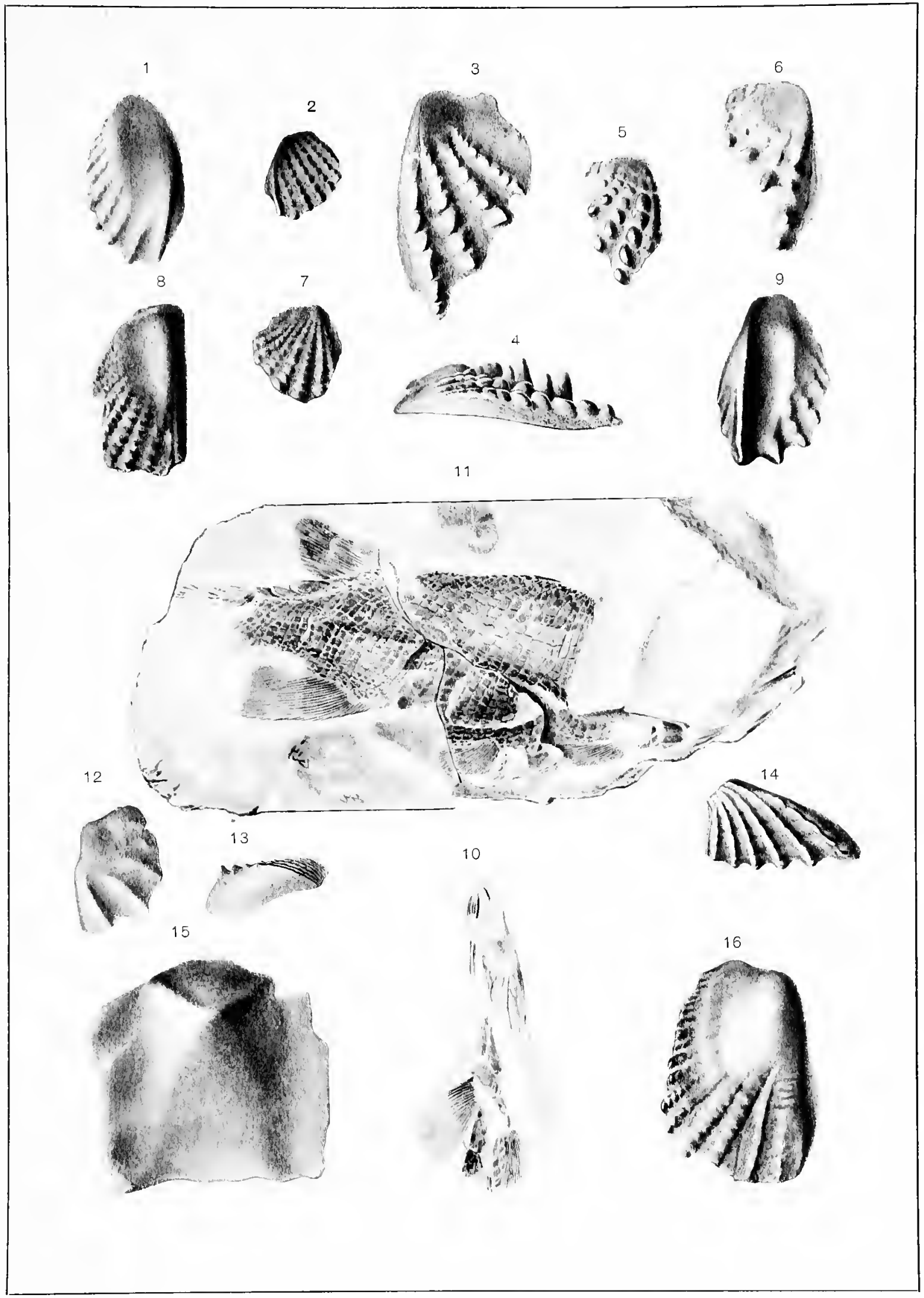





\section{Dipterus costatus Eastm.}

Page $\mathbf{x} 6 \mathrm{r}$

9 Left mandibular dental plate. Natural size

State Quarry beds (Upper Devonic); North Liberty, Johnson co., Ia. Original in Museum of Comparative Zoology, Cambridge, Mass.

\section{Rhadinichthys sp. nov.}

$$
\begin{gathered}
\text { (See plate 9) } \\
\text { Page } \text { I72 }^{2}
\end{gathered}
$$

Io Imperfect Palaeoniscid fish, probably representing a new species of Rhadinichthys, in the neighborhood of R. geikiei Traq. Ventral aspect of thoracic region, showing details of pectoral fins, jugular plates and disarranged branchiostegals. $\quad \mathrm{x}_{2}$

Chemung beds; Warren, Pa.

Original in Museum of Comparative Zoology, Cambridge, Mass.

I I Lateral aspect of trunk of same individual as shown in figure io. Position of fins, squamation, and dorsal ridge scales well displayed. $\quad \mathrm{x}_{2}$

\section{Dipterus sp.}

Page $16_{4}$

I2 Worn example of palatal dental plate. Natural size

State Quarry beds (Upper Devonic); North Liberty, Johnson co., Ia. Original in Museum of Comparative Zoology, Cambridge, Mass.

\section{Dipterus nelsoni Newb.}

Page 163

I3 Anterolateral aspect of right mandibular plate. Natural size

Chemung beds; Warren, $\mathrm{Pa}$.

Original in Museum of Comparative Zoology, Cambridge, Mass.

I4 Oral aspect of same specimen as shown in figure I3

\section{Dipnoan dental plate}

Page 164

I 5 Undescribed, somewhat worn, Dipnoan dental plate, gen. et sp. nov. Natural size

State Quarry beds (Upper Devonic); North Liberty, Johnson co., Ia.

\section{Dipnoan dental plate}

$$
\text { Page } \mathrm{I}_{4}
$$

I6 Worn dental plate from same horizon and locality as that shown in figure i 5. Natural size 
PLATE 5

Dinichthys dolichocephalus sp. nov.

Page ${ }^{2} 35$

I Head shield, mandibles and various plates of the dorsal and ventral armoring in natural association on a single slab. $x 2 / 3$

Naples shale; Sturgeon Point, near Buffalo, N. Y.

Original in Cabinet of the Buffalo Society of Natural Sciences

\section{Dinichthys pustulosus Eastm.}

(See plates 2 and $\mathrm{r} 2$ )

Page $13^{\circ}$

2 External aspect of left mandibular ramus, partly restored. $x \mathrm{x} / 2$ Oneonta sandstone; Delhi, Delaware co., N. Y.

Original in New York State Museum

3 External aspect of left mandibular ramus. $x \quad 2 / 3$

Hamilton limestone, Milwaukee, Wis. 


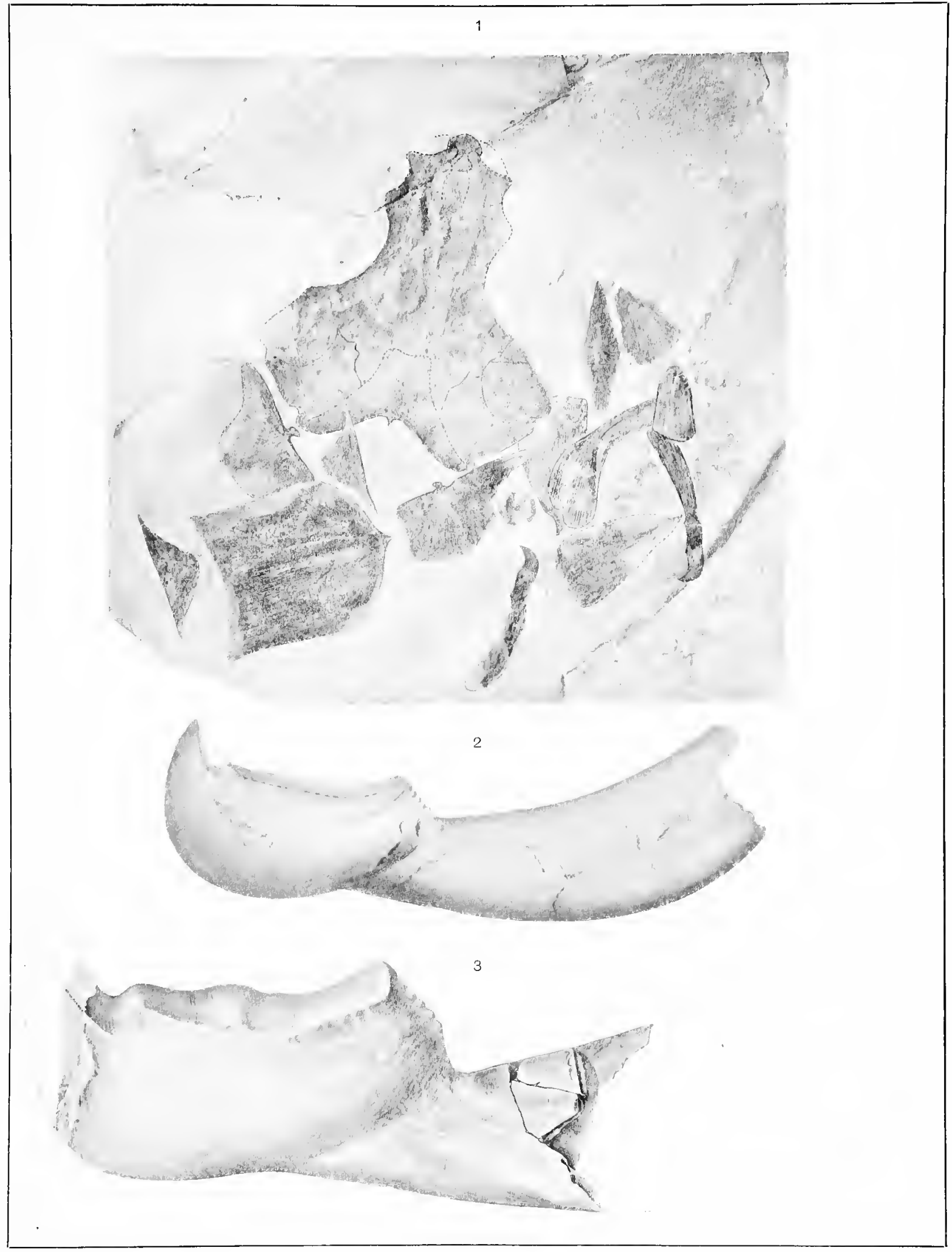



PLATE 6

205 
Dinichthys sp. indet.

Page 139

I Left postero-dorsolateral plate of a large sized Dinichthyid, possibly identical with D. curtus Newb. Tubercular ornament, sensory canals, and marks of overlap by contiguous plates well shown. Natural size

Oneonta beds; Franklin, N. Y.

Original in New York State Museum

Dinichthys newberryi (Clarke)

Page 133

2 Redrawing of type mandible. Natural size

Genundewa limestone ; Canandaigua lake, N. Y.

Original in United States National Museum, Washington

Remains of the same or closely similar species are also known from the New Albany (= Genesee) Black slate near Louisville, Ky. 


PLATE 7

207 


\section{Bothriolepis nitida Leidy \\ (See plate 3) \\ Page 5o}

I "Shoulder of arm" in articulation with ventrolateral plate. Natural size

Chemung beds; Blossburg, Tioga co., Pa.

Original in New York State Museum

\section{Dipterus fleischeri Newb.}

Page $x 6_{2}$

2 Right upper dental plate. Natural size

Oneonta beds; Franklin, Delaware co., N. Y.

Original in New York State Museum

\section{Ctenacanthus chemungensis Claypole}

Page 77

3 Superficial ornamentation of spine enlarged. $\times 3$

Chemung beds; between Friendship and Nile, Allegany co., N. Y.

Original in New York State Museum

\section{Dinichthys lincolni Claypole}

Page I29

4 Right vomerine tooth, viewed from the front. Natural size

Marcellus shale; Geneva, Ontario co., N. Y.

Holotype in the New York State Museum

5 Inner lateral aspect of same specimen, showing fractures due to mechanical deformation. Natural size

6 Ibid. Inferior aspect. Natural size

\section{Asterolepis clarkei sp. nov.}

Page $4 \circ$

7 Mold of interior surface of posterior dorsal median plate. Natural size

Chapman sandstone; Chapman Plantation, Aroostook co., Me.

Original in New York State Museum

8 External surface of preceding. Natural size 
Memoir 10. N. Y. State Museum.

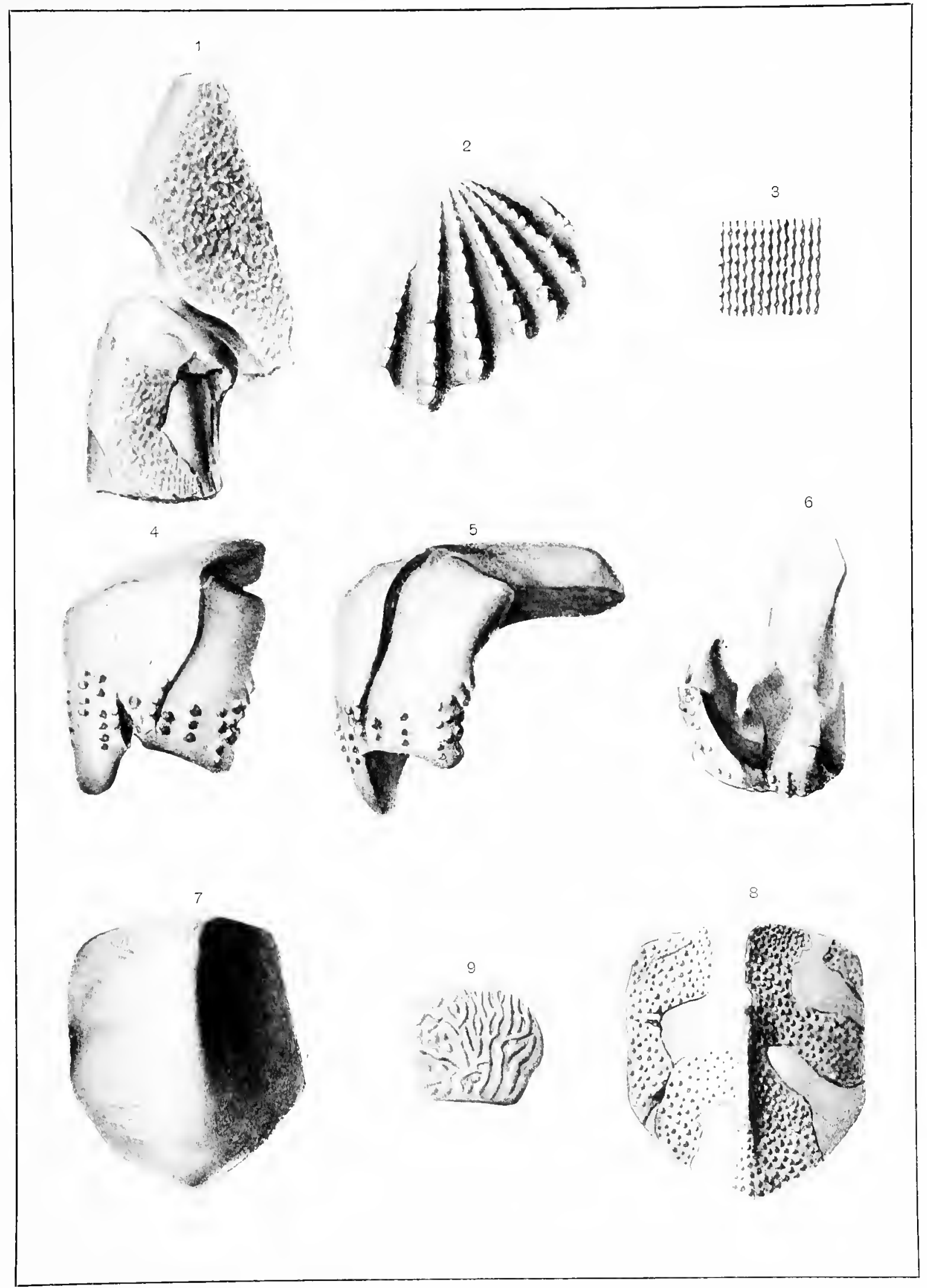





\section{Holoptychius americanus Leidy}

Page $16_{7}$

9 Imperfect scale. Natural size

Chemung beds; Jefferson, Delaware co., N. Y.

Original in New York State Museum

Compare with A. S. Woodward's figures of Holoptychius scales from the Upper Devonic of East Greenland (Bihang till K. Svenska Vet.

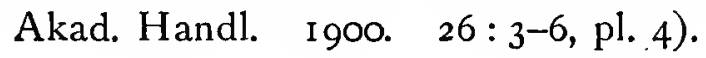


PLATE 8

Cladoselache sp. indet.

I Detached pectoral fin. $x 3 / 4$

Page 57

Naples shale, Portage beds; Eighteen Mile creek near Buffalo, N. Y. Original in Cabinet of Buffalo Society of Natural Sciences.

210 


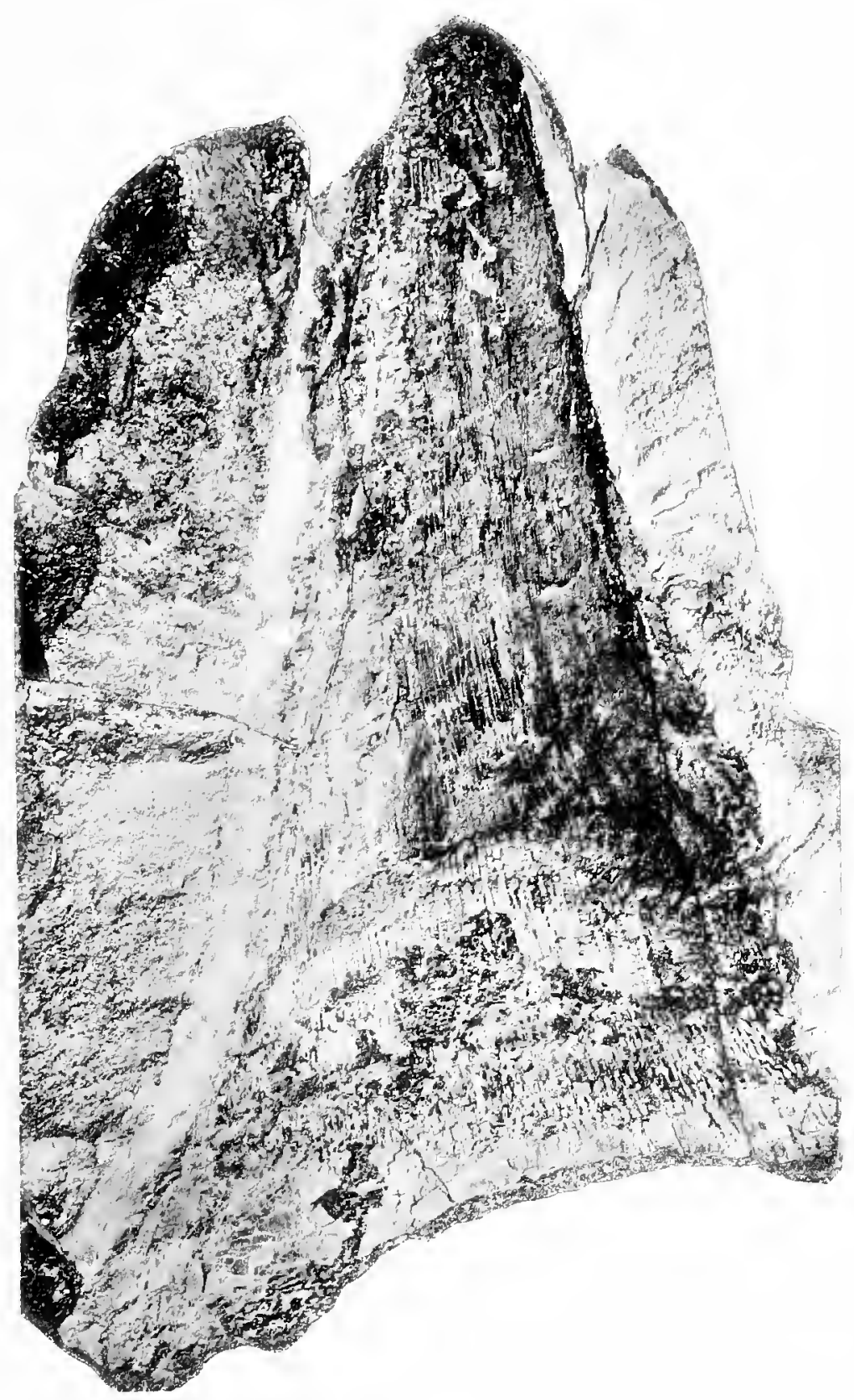



PLATE 9

2II 
Onychodus hopkinsi Newb.

(Sez plates 1 and 3 )

Page 169

1 Detached presymphysial tooth. Natural size

Chemung beds ; Franklin, Delaware co., N. Y.

Original in New York State Museum

(It will be noted that, as respects size and curvature, teeth of this species are indistinguishable from the earlier O. sigmoides; the average size of the Chemung teeth, however, is inferior to either the example here figured or the original of plate I, figure i4. For a complete series of presymphysial teeth in natural association, see pl. 3, fig. 3.)

2 Detached presymphysial tooth from same horizon and locality as the last. Natural size

Original in New York State Museum

Coccosteus occidentalis Newb.

Page 115

3 Dorsomedian plate of type specimen, refigured to show presence of sensory canals and extent of long posterior process. Natural size

"Corniferous limestone," Ohio

Original in American Museum of Natural History, New York

Rhadinichthys sp. nov.

(See plate 4)

Page I72

4 Trunk of imperfect Palaeoniscid fish, probably representing a new species of Rhadinichthys. $\mathrm{x} 4 / 3$

Photograph of the trunk of holotype shown in plate 4 , figures Io and I I Chemung beds, Warren, Pa.

Macropetalichthys rapheidolabis Norwood \& Owen

(See plate II)

Page ${ }_{203}$

5 Disarticulated plates of head shield belonging to a single individual. Natural size

Columbus limestone (="Corniferous"); Columbus, $\mathrm{O}$.

Original in American Museum of Natural History, New York. (Cat. no. $269 \mathrm{G}$ ) 


\section{FISHES}

Memoir 10. N. Y. State Museum.

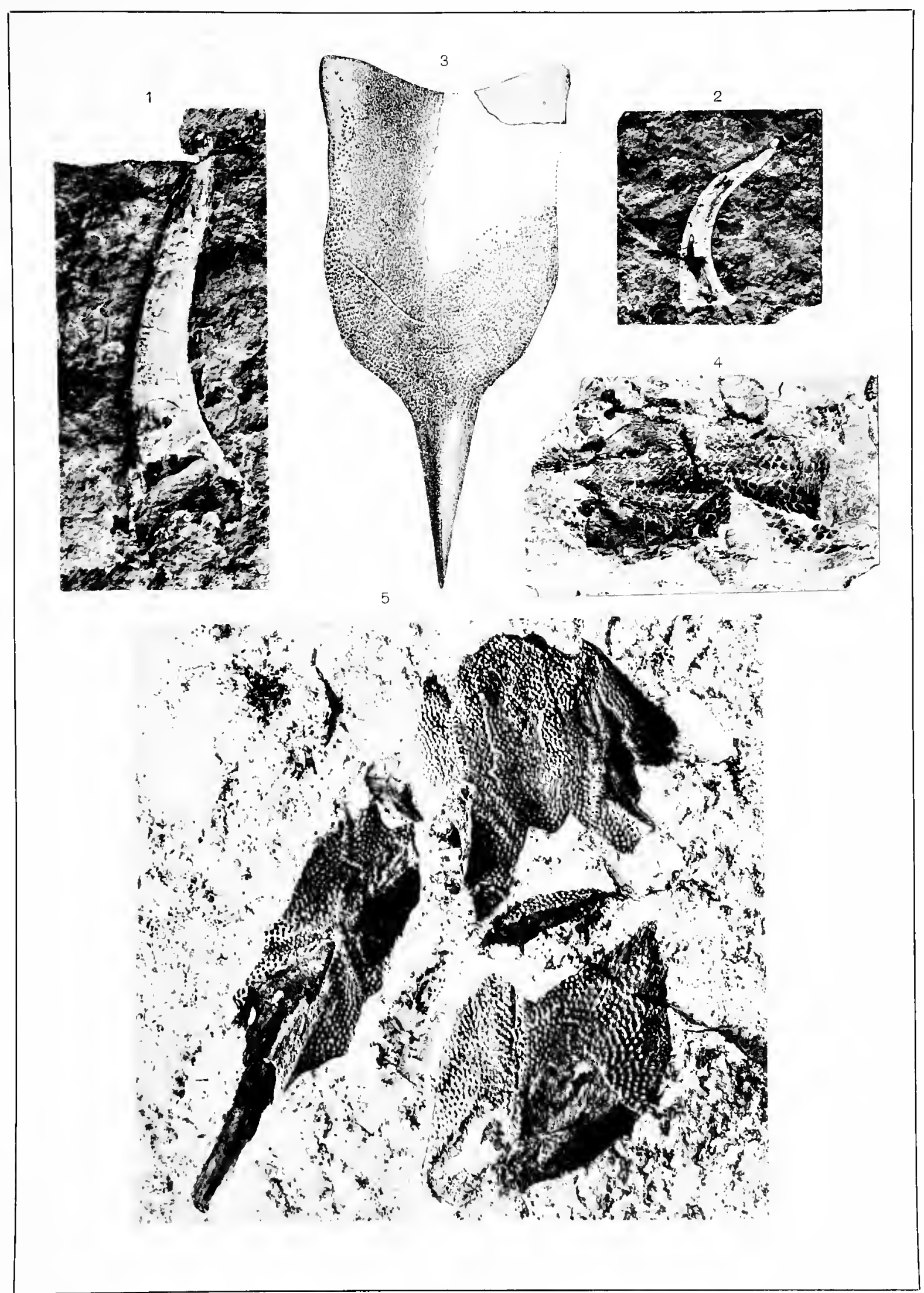



PI.ATE 10

213 


\section{Dinichthys halmodeus (Clarke) \\ (See plate 2) \\ Page 126}

I Fragment showing median occipital region of a large cranial shield.

Natural size

Agoniatite limestone (Marcellus shale); Hendrick's ledge, west of Manlius, N. Y.

Original in New York State Museum

\section{Protitanichthys fossatus sp. nov.}

$P$ age 144

2 Antericr portion of head shield, seen from the cerebral aspect. Natural size

Delaware limestone (="Corniferous"); Delaware, O.

Original in Museum of Comparative Zoology, Cambridge, Mass.

A diagram showing arrangement of cranial plates and course of sensory canals will be found in text figure 30 , page 146 


\section{FISHES}

Memoir 10. N. Y. State Museum.
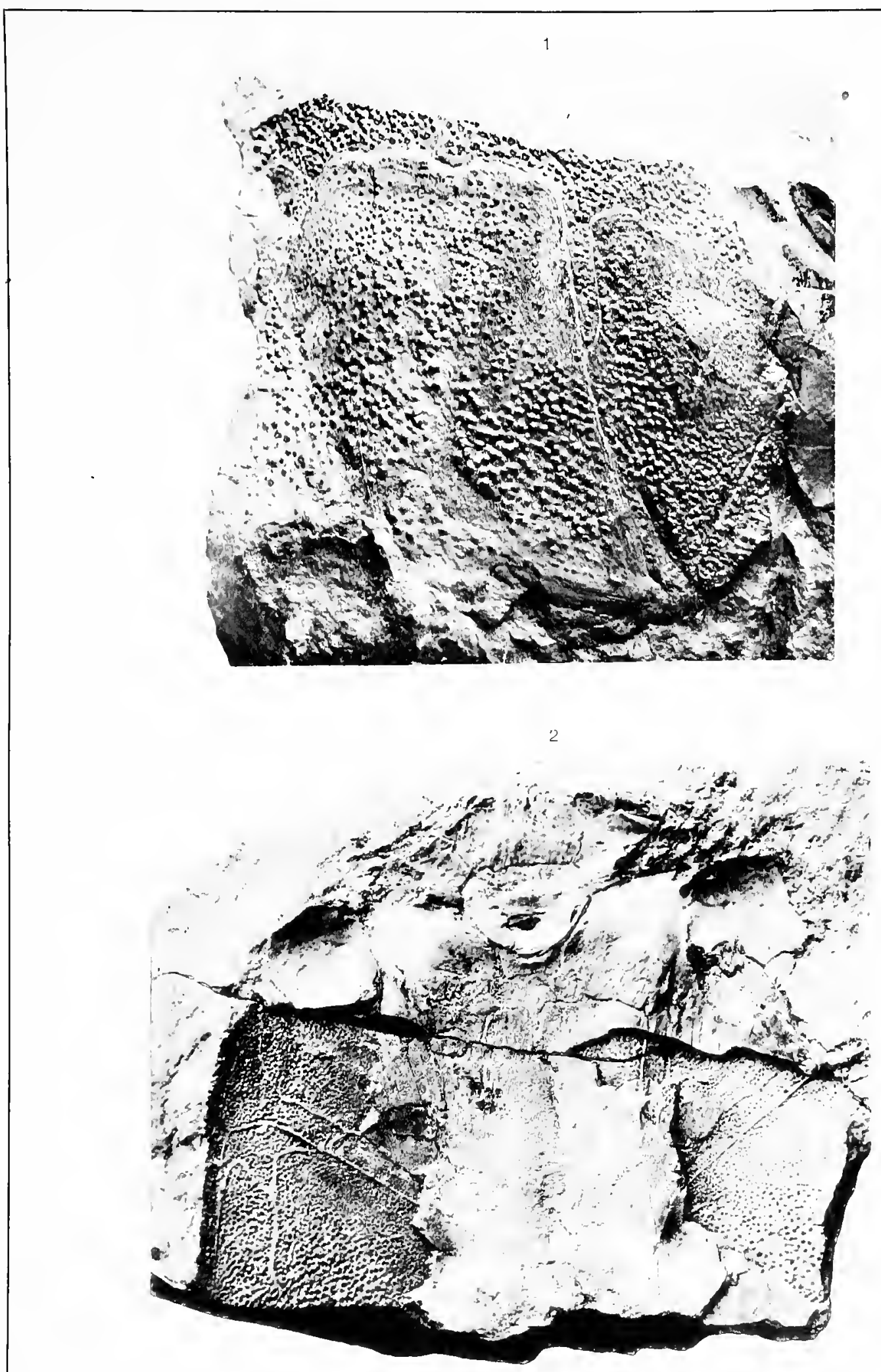

PLATE II 215 
Macropetalichthys rapheidolabis Norwood \& Owen

(See plate 9)

Page 103

I Dorsal aspect of large head shield, denuded of superficial ornamentation, and showing sutures. $\times 8 / 9$ (approximately)

Delaware limestone (= "Corniferous"); Delaware, $\mathrm{O}$.

Original in Ohio Wesleyan University, Delaware, $\mathrm{O}$.

216 


\section{FISHES}

Memoir 10. N. Y. State Museum.

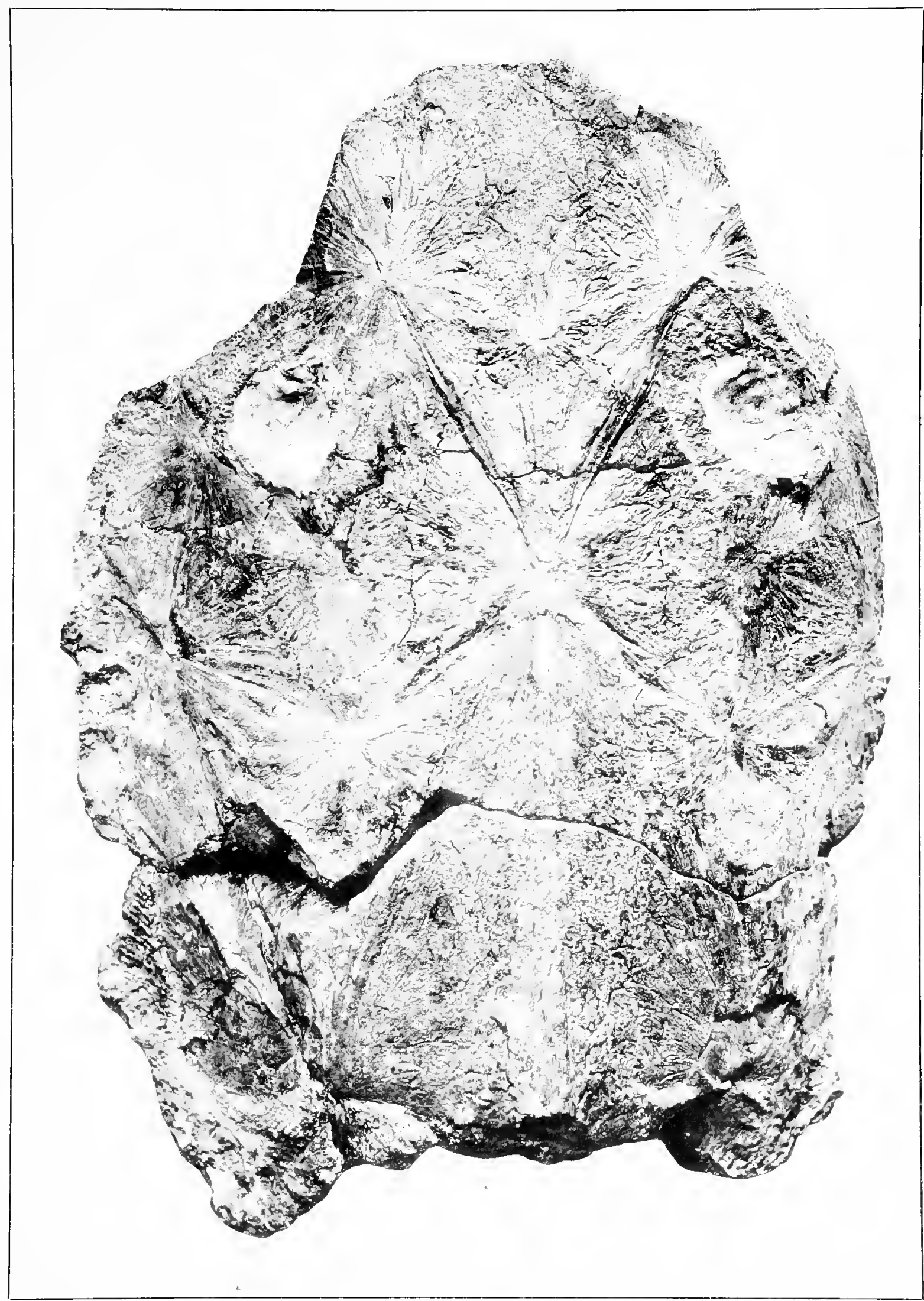



PLATE 12

2I 7 


\section{Dinichthys pustulosus Eastm.}

(See plates 2 and 5 )

$$
\text { Page } \times 33^{\circ}
$$

I Dorsal aspect of moderate sized head shield, showing cranial sutures, sensory canals and other features very distinctly. The median occipital plate is removable, showing conformation of visceral surface. x $3 / 4$

Lower part of the Cedar Valley limestone (Middle Devonic); near Rock Island, Ill. Collected by A. S. Tiffany

Original in Museum of Comparative Zoology, Cambridge, Mass. 


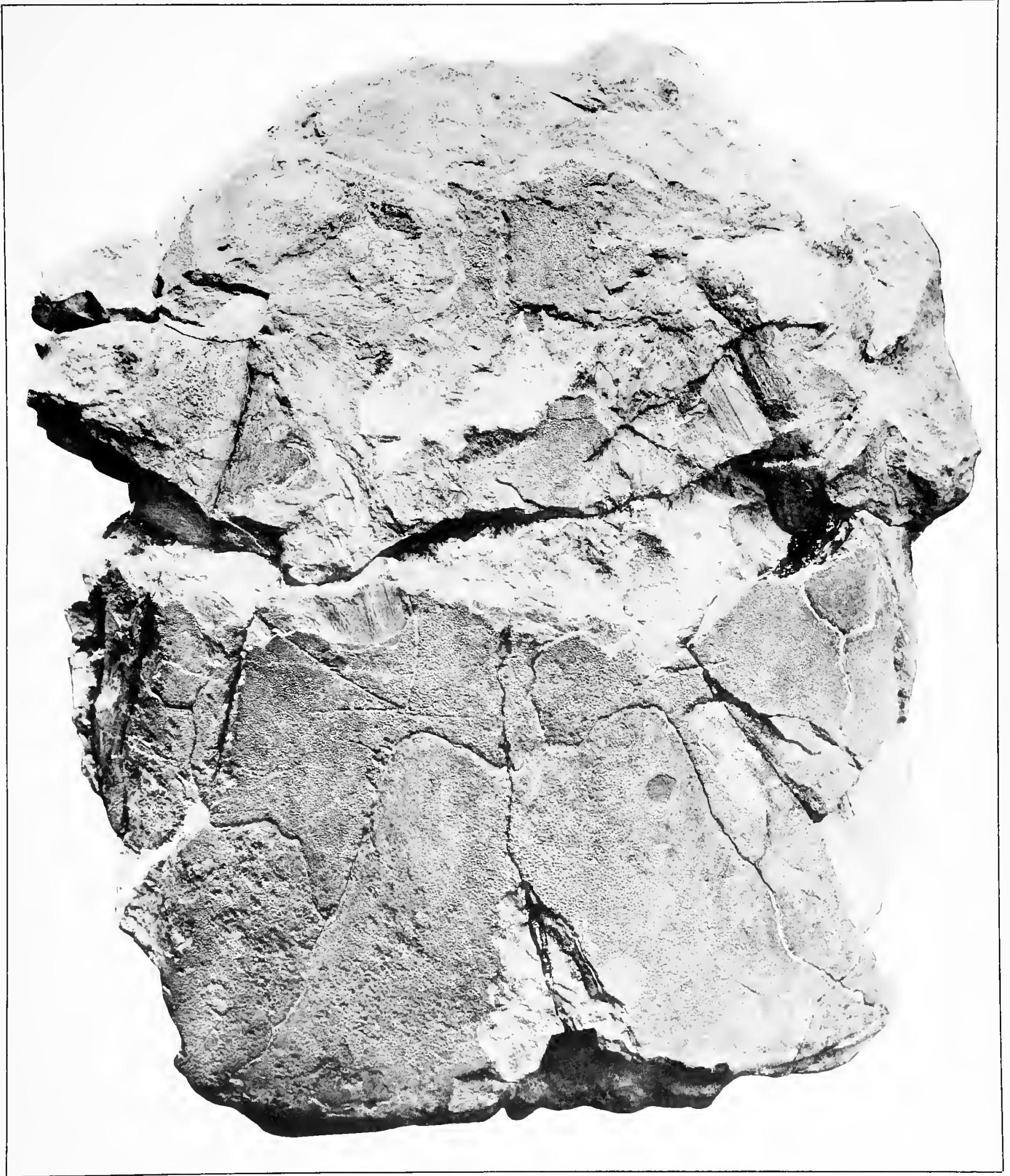



PLATE I3

219 
Glyptaspis abbreviata sp. nov.

Page ${ }^{4} 4$

I Right antero-ventrolateral plate. Natural size

Portage beds; Valois (North Hector), N. Y.

Original in New York State Museum

Similarly ornamented dermal plates belonging probably to the same species, and accompanied by remains of $\mathrm{D}$ in ichthys new berryi Clarke, Aspidichthys, and other Arthrodires, occur in the New Albany (= Genesee) Black slate near Louisville, Ky. In the description of this form [p. I $47-49]$, the locality is wrongly stated to be near Lexington. 


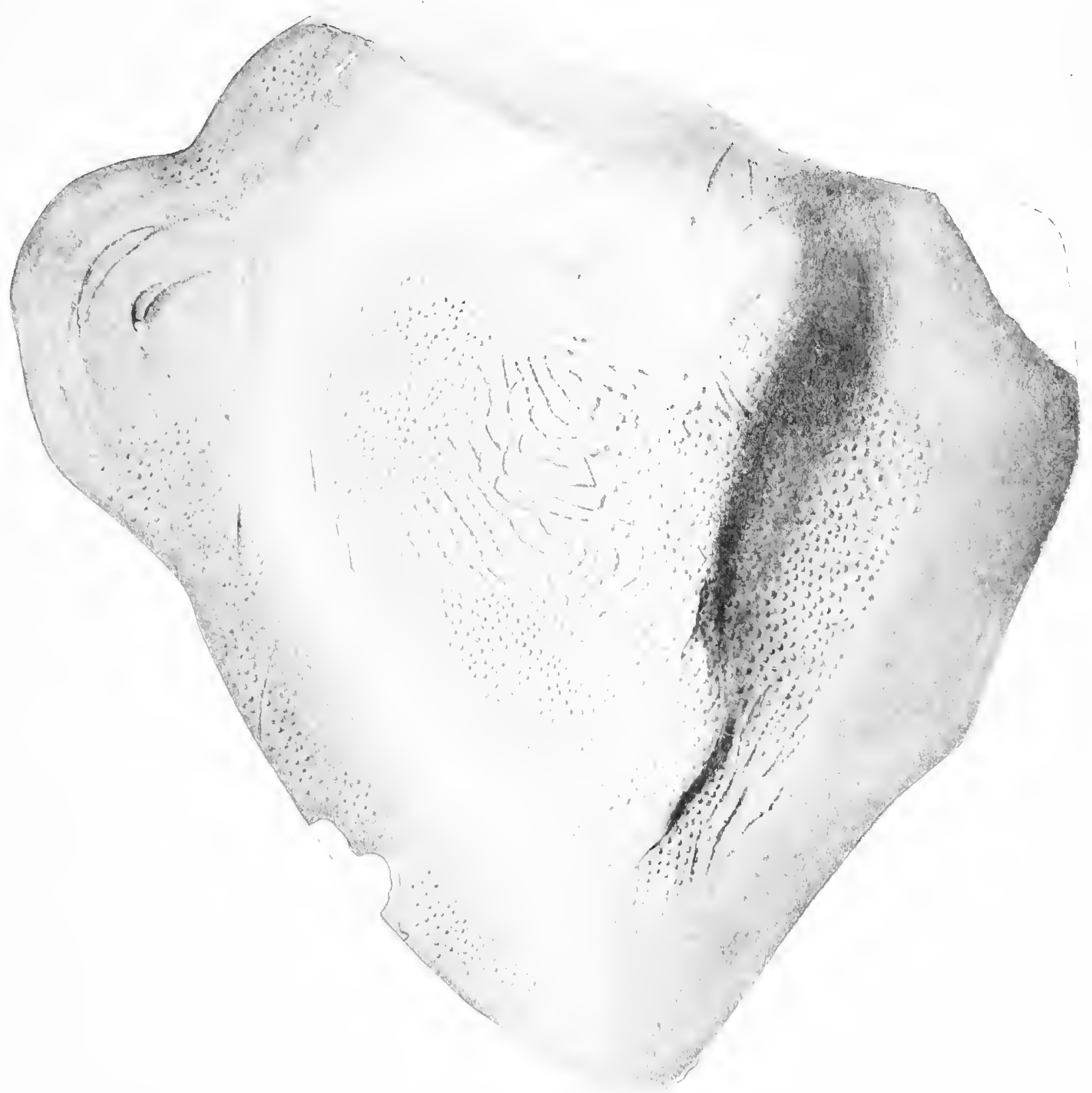



PLATE 14

221 


\section{Mylostomid upper dental plates}

I, 3 Imperfect left posterior palato-pterygoid plates of the type species of Mylostoma (M. variabile Newb.) from the Cleveland shale of Sheffield, O.

2 Left anterior palato-pterygoid plate of the same species, and from the same horizon and locality.

4 Right posterior palato-pterygoid plate of the same species, from same horizon and locality.

5, 6 Right and left palato-pterygoid plates of Dinomylostoma b e e cheri Eastm. from the Portage shale of Mount Morris, N. Y.

7 Supposed vomerine tooth of an unidentified Arthrodire, from the Cleveland shale of Ohio

All figures of natural size. Compare with reconstructions shown in text figure 18 , page 98 , and text figure $3 \mathrm{I}$, page ${ }_{15}$. 


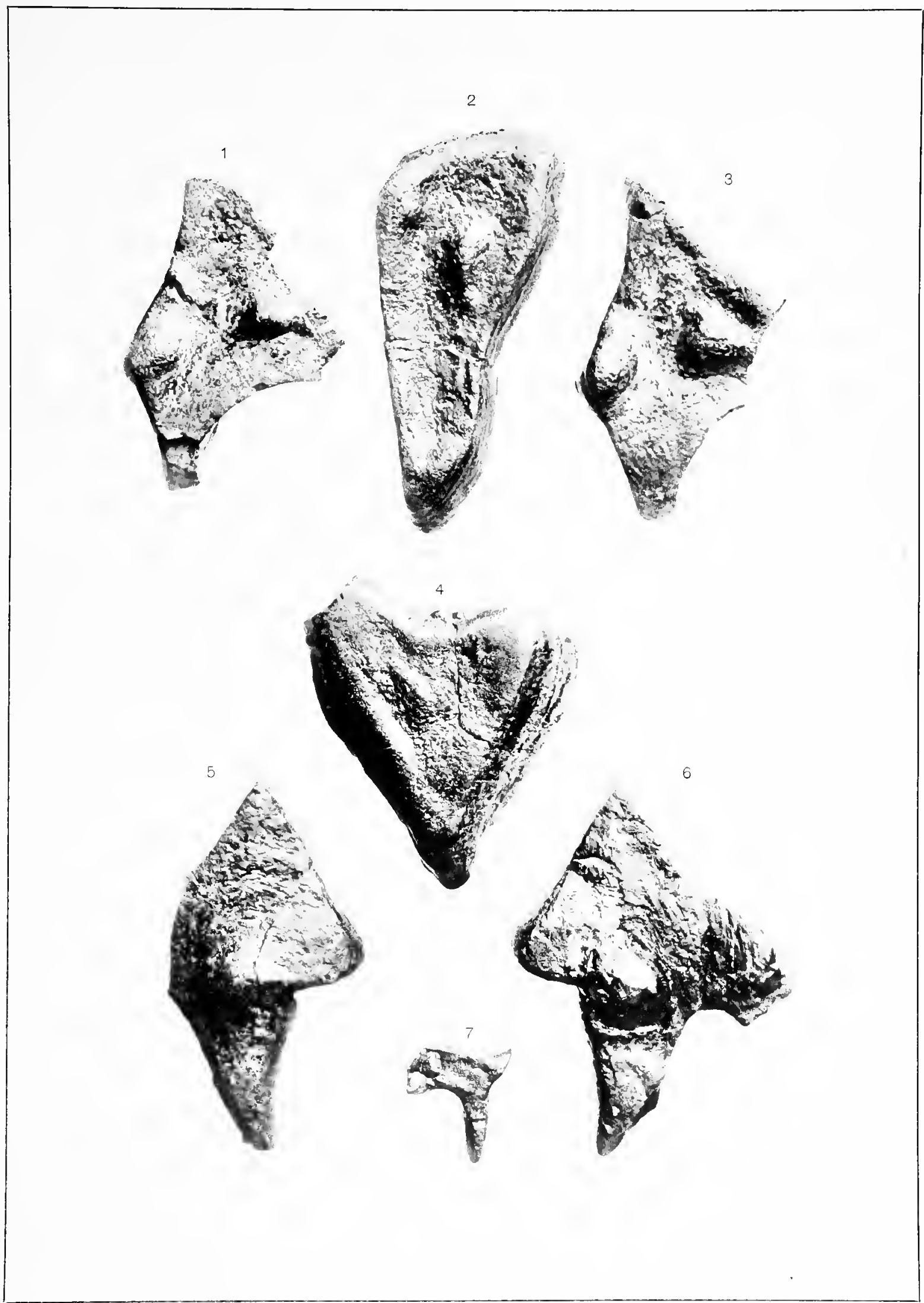



PLATE I5

223 


\section{Dinomylostoma beecheri Eastm.}

(See plate $\mathrm{I}_{4}$ )

Page 15x

I, 2 Inner aspect of mandibles belonging to type individual. Natural size Portage beds, Mount Morris, N. Y.

Original in Peabody Museum, New Haven, Ct. 


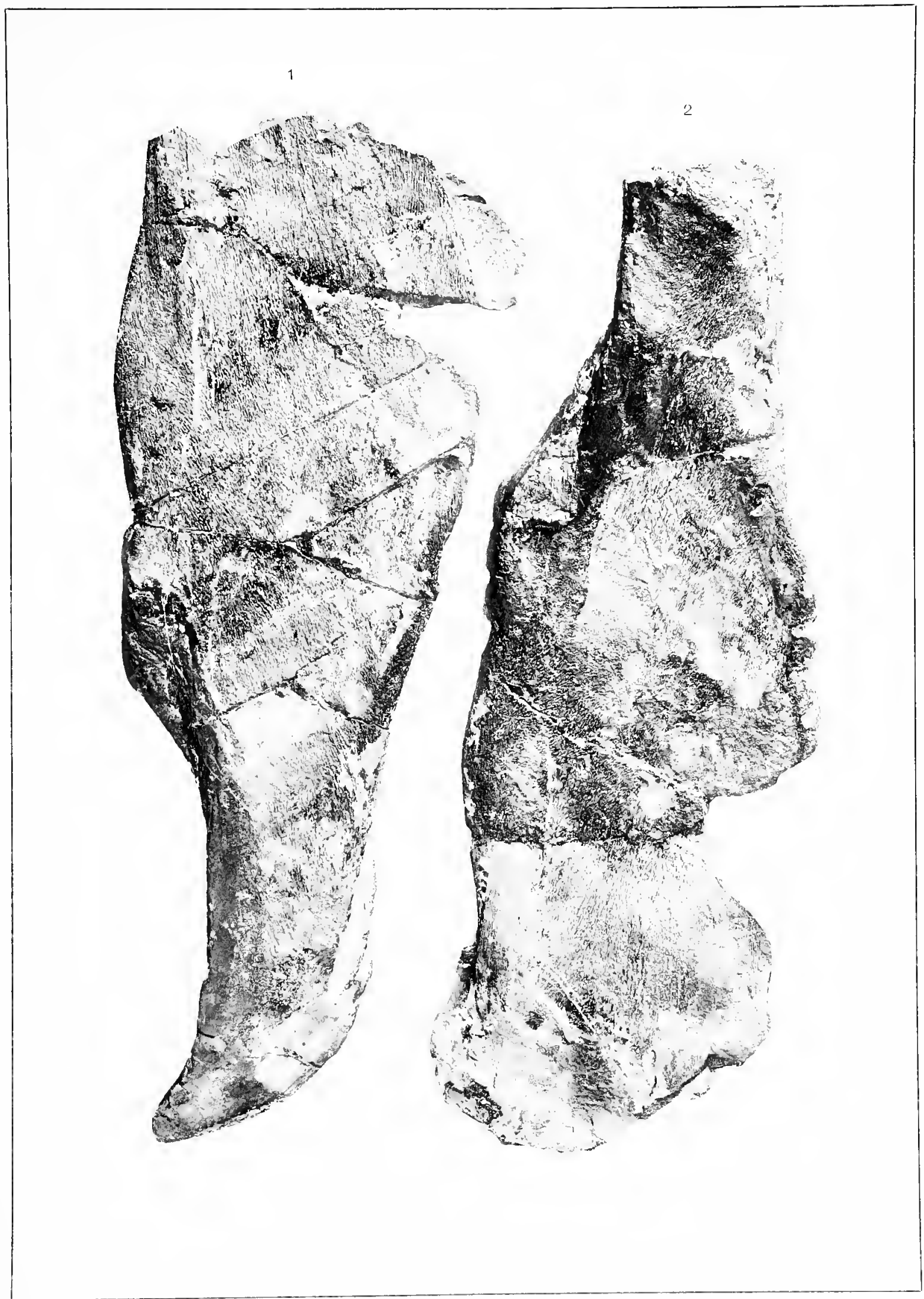





\section{N DEX}

Page numbers referring to descriptions of genera and species are printed in black face type.

Acanthaspis, 78 , I I 5 , I 17 , 193 .

armata, I4, II7-I8, 198.

armatus, 117 .

decipiens, II8.

pruemensis, $x \mathrm{I} 8$.

Acanthodes, $\mathrm{I} 8 \mathrm{r}$.

affinis, I6.

concinnus, 16.

? pristis, I7, 64 .

semistriatus, I3.

Acanthodians, $179,180,18 \pi$.

Acanthodidae, 23.

Acanthodii, 23, 63-64.

Acanthoëssus ? pristis, 64 .

Acantholepis, 78-79, 80, 193 .

fragilis, $14,15,79-80,200$.

pustulosus, 79 .

Acanthopterygii, I83.

Acipenseridae, I7I.

Actinophorus clarki, r9.

Actinopterygii, 23, 90, 92, I65, I70-72.

Agassichthys agassizi, I 12.

manni, IO2, IO3.

sullivanti, I02, I03.

Agassiz, Louis, cited, IOI, I I6; mentioned, 177 .

Agnatha, I2-I 3, I6, 20, 22, 23, 24-54.

Agoniatite limestone, 129 .

Allegany county, $2 \mathrm{I}$.

Ambocoelia umbonata, 85 .

American Museum of Natural History, acknowledgments to, $\mathrm{x} 2$.

Amia, 182.

Anarthrodira, 105, IIx.

Anaspida, 23, 28, 3 I.
Antiarcha, 23, 26, 27, 28, 32-33.

Apateacanthus, 79, 80.

vetustus, I7, 8I, 200.

Apedodus priscus, 2I, I66, 196.

Appalachian strait, 189.

Arachnids, 28.

Arisaig series, I3.

Aroostock county, Me., 13, 32.

Arthrodira, I 5, 20, 23, 88, 89-1 57, I 58, I 59, I92, 220; systematic arrangement, 99 .

Arthrodire indet., 198.

Arthrognathi, 90 .

Ascidians, 28.

Aspidichthys, I57, 220.

$s p ., 15$.

clavatus, 19,156 .

? notabilis, I6, I 57 .

Asterolepidae, 23, 26, 27, 28, 32, 33-54, 89, 90, 9 I, I I8.

Asterolepis, 32, 36, 39-40. clarkei, I 3, 32, 40-4I, 208.

hoeninghausii, IOI, I 12 .

maxima, 5o, 5I, 54.

ornata, 40.

Asterosteus, 99, 104, 105, 106, I10, I12, I93.

stenocephalus, I4, II3.

Astraspis desiderata, I2, 33.

Ateleaspidae, 23.

Ateleaspis, 27.

tessellata, 26 .

Atthey, T., cited, 97 .

Balfour, cited, 158.

Bedford, O., I8. 
Beecher, Charles E., mentioned, 77, I 52. Belgium, 52, I38.

Bell, cited, I92.

Belonorhynchidae, I 70.

Berea, O., I8, I9.

Berea grit, I8.

Berycoids, I 83 .

Birkeniidae, 23, 9I.

Black shale, I8, I34, I37, I56.

Black slate, I3I, I33, I39, I47, I48, I72.

Bloomfield sandstone, I 2 .

Blossburg, Pa., 22.

Bohemia, I87.

Bothriolepis, $8,27,32,35,36,37,3^{8}, 39$, 42 , I I I.

canadensis, I $6,42,43-49,50,5^{I}$.

coloradensis, 20, 53-54.

leidyi, 50 .

major, 53, 54 .

minor, $20,22,52,148$.

nitida, 22, 50-5I, 52, I 48, 200, 208.

Boulenger, cited, 88.

Brachydirus, II4.

Bradford county, Pa., 20, 21, 22, 52, 77, I 56 , I 57 .

Branson, E. B., cited, 62.

Bridge, T. W., cited, 9I, I26, I7o.

Bristol Center, I7, I34.

Brontichthys clarki, I9.

Buffalo, Ia., I6.

Buffalo, N. Y., 59, 79, 83, I34.

Calamoichthys, I82.

Calceola beds, I 87 .

Calciferous sandstone, I72.

Callognathus serratus, I7, I9.

Campbellton, N. B., I2, I3, I89, I90.

Canandaigua lake, I7, I34.

Canyon City, Col., I2, 33.

Cashaqua shale, I7, 8I, I56.

Cashong creek, 76 .

Catskill, 20.
Catskill beds, 22, 51, 87, 88, I39, I62, I63, I68.

Cattaraugus county, $2 \mathrm{I}$.

Cayuga lake, i7.

Cazenovia, I39.

Cedar Valley limestone, I4, I5, I6, 69, 73, 83, I60, I6I, I69.

Cephalaspidae, 23, 27, 90, 9I, II7.

Cephalaspis, 27, 3I, I67, I9I.

sp., I3.

campbelltonensis, I2.

dawsoni, I3.

jexi, I3.

laticeps, I6.

murchisoni, $3 \mathbf{I}$.

Ceratodontidae, 23.

Ceratodonts, 89, 93, 94, 95, 96, 99, I I I, I 58.

Ceratodus, 56, 88, I 82 .

sturii, 95, 96.

Cestracion, 65 .

philippi, 65.

Chapman Plantation, Me., 4I.

Chapman sandstone, I3, 32, 4I.

Cheiracanthus costellatus, I3.

Cheirolepis, I7o, I7I.

canadensis, I7, I 7 I.

trailli, I7I.

Chelyophorus, I Io.

Chemung beds, $58,63,69,70,88$, І І 5 , І I 6 , I 38, I 39, I 56, I57, I68, I69, I 72.

Chemung group, 20, 21, 22, 52, 74, 75, 77, 78,87 .

Chemung species of Dipterus, I63-64.

Chimaeroidei, 23, 66-88, 9I, I49.

Chlamydoselachus, 54 .

Chondropterygii, 27.

Chondrostei, 23, I70-72, I79, I82.

Cladodontidae, 23, 6I-63.

Cladodus, 57, 58, 6I-63, I93.

$s p ., 20,63$.

carinatus, 63 .

claypolei, $\mathbf{I} 8$. 
Cladodus (continued)

concinnus, 18,63 .

coniger, 20,63 .

monroei, I5, 62, 196.

prototypus, I3, 6I-62, I97.

rivi-petrosi, $\mathrm{I} 8$.

striatus, $6 \mathrm{I}-62$.

subulatus, $\mathbf{} 8$.

terrelli, I8.

tumidus, 18.

Cladoselache, I4, I7, 54, 6r, I40, r8I.

sp., I 7, 57-58, 210.

clarki, 18.

fyleri, I 8, 55 .

kepleri, I8.

sinuatus, I8.

Cladoselachidae, 23.

Clark, William, mentioned, I23.

Clarke, John M., acknowledgments to, I 2 ; cited, 4I, 58, 59, 63, 70, I 28, I33-34, I 47, I48, I7I, I85, I86, I87, I88, I89, I90; mentioned, 64,72 ; summary of classification of the New York Devonic, Io.

Classification of the New York Devonic according to John M. Clarke, Io; according to James D. Dana, I I.

Claypole, cited, 30, 77, I29, I36, I43, I 74 .

Cleveland, O., I9.

Cleveland shale, I8, I9, $57,61,63$, I 3 I, I38, I39, I47, I49.

Clifton Springs, I4, II 5 .

Climatius, I8I. latispinosus, $\mathrm{I}_{3}$.

Clinton beds, $\mathbf{} 2$.

Coccosteans, 89, 90, 9I, 93 .

Coccosteidae, 23, 27, 91, 99, II3-49.

Coccosteus, 27, 94, 95:97, II4, I I 5-I6, I I8, I I9, I 2 I 122, I 25, I 26, I 28, I 35, I 36 , I 40, I 44, I 45, I 53, I67, I93.

sp., I4, I96.

americanus, I 16.
Coccosteus (continued)

angustus, 92.

canadensis, 17, II5.

cuyahogae, I8.

decipiens, I I6, I I8, I I9.

? halmodeus, 126.

macromus, 2I, II 5 , II 6 .

occidentalis, I4, I I5, II6, I45, 2 I2.

(Liognathus) spatulatus, I4.

Coelacanthidae, I82.

Coelolepidae, 23, 27, 9 I.

Columbus, O., I $3,62,85$.

Columbus limestone, 9, I3, I4, 61, 62, 67, 80, 84, II2, II3, I69.

Connecticut trough, 189 .

Conspectus of species, I2-22.

Cope, E. D., cited, 56, 89, IOI, IO3, IO5, I08, I09, I 5 , I 6 , I 22.

Corniferous limestone, $9,62,84,85$, II 2 , I38.

Crossopterygii, I5, 23, 27, 89, 95, I64, I65-69, I79-I8I.

Crustaceans, 28.

Ctenacanthus, 74, 75-76, 86.

angustus, 18.

chemungensis, 21, 77-78, 208.

clarki, 18.

compressus, I8.

randalli, $2 \mathrm{I}, 77$.

speciosus, 76 .

vetustus, 18 .

wrighti, $14,76$.

Ctenodipterini, 23, 88, 89, 93, 97, 98, 99, I04, IO9, I I3, I 50, I 5 I, I 57-65.

Ctenodontidae, 23.

Ctenodus, 95, 160 .

fleischeri, I62.

sherwoodi, see Dipterus (Ctenodus)

sherwoodi.

wagneri, 19.

Cuba sandstone, $2 \mathrm{I}$.

Cumberland, Md., I2, 73.

Cuyahoga county, O., I8, I9. 
Cyathaspis, 27, 28, 30 .

acadica, 12,28 .

Cyrtacanthus, 66, 193.

dentatus, 13.

incurvus, $\mathrm{I} 3$.

Dana, James D., classification of the New York Devonic, II ; cited, I89.

Davis, J. W., cited, 75 .

Dawson, J. W., cited, I90, I9I.

Dean, Bashford, acknowledgments to, I 2 ; cited, $30,55,56,57,58,67,73,90$,

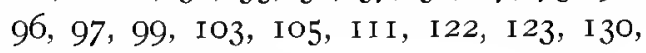
I 49, I 56, I 78 .

Delaware, O., 19, 85, 146.

Delaware county, 20, 2I, 22, 5I, 52, 74, I $39,162,169$.

Delaware limestone, 9, I3, 14, 67, 80, 84, I I 2, I I 3, I46, I69.

Delhi, 22, I68.

Delphi, 133 .

Dendrodus arisaigensis, 13 .

Devon Point, Col., 20, 54.

Devonic, boundaries of local provinces and subprovinces may be traced by faunal changes, I86; of Gaspé, I90; faunas, provincial character, I86; an era of provincial development of marine faunas, I85; New York, clâssification according to John M. Clarke, Io; classification according to James D. Dana, II ; two geological provinces, 184 ; vertebrates, distribution, 187.

Devonic, Middle, faunal distribution, I88; fauna of the Hudson Bay region, similarity to the Mississippian Onondaga, I88; Ulsterian and Erian as divisions of, I 88 ; faunal list showing distribution of fossil fishes, I93.

? Dictyorhabdus priscus, I2, 67 .

Dinacanthodes, 83 .

Dinichthyid, I7.
Dinichthys, 90, 9I, 94, 95, 98, IO5, II4, II8-26, I $40,142, I 43, I 45, I 49,150$, I5I, I 52, I93; dentition of Neoceratodus and, 96-97.

$s p .$, I6, I7, 22, 139, 206.

canadensis, 15 .

clarki, 19.

curtus, 19, 21, 138-39.

dolichocephalus, I7, I35-36, 204 .

gouldi, I9.

gracilis, I9.

halmodeus, I 5, I26-29, I3I, I 35, I 36, I44, I99, 214.

herzeri, I9, I 18, I I9, I 27, I 29, I 3I, I 34 . intermedius, I9, I I9, I20, I29, I 30 , I3 I,

I 37, I 38, I 55 .

lincolni, I 5, I29-30, 208.

minor, 19, I34.

newberryi, I7, 133-34, 206, 220.

precursor, I4, I38.

prentis-clarki, I9.

pustulosus, I5, I6, I7, 20, I30-33, I39, 198, 204, 218.

ringuebergi, I7, I34.

terrelli, I9, I18, I I9, I25, I 30, I3I, I34.

tuberculatus, I5, 16, 21, I37-38, I39.

Dinonylostoma, 94, 95, 97, 98, г2 I, г 5 r. beecheri, I7, I5I-56, 222, 224.

Diplacanthidae, 23, 64 .

Diplacanthus horridus, 16. striatus, 16.

Diplodus, 58-6o.

$s p ., 20$.

priscus, 20, 59, 196.

striatus, 20, 60, 197.

Diplognathus, 97.

mirabilis, 19.

Dipneusti, 23, 27, 88-164, 91, 92, 95.

Dipnoan dental plates, I98, 203.

Dipnoans, 88, 89, 90, 91, 92, 93, 94, 95, 99, I04, I05, I08, I49, I50, I 5 I, I 57, I $_{5} 8$, I65, I79, I 80 . 
Dipnoi, I82; term, 88.

Dipteridae, 23, 159-63.

Dipterus, I6, 95, Iо8, I Io, I 58, I59-63, I93; Chemung species, $163-64$.

sp., 202, 203.

alleghaniensis, $2 \mathbf{I}$.

angustus, 22.

calvini, I6, I6о-6I, 202.

contraversus, 22.

costatus, 20, $16 \mathrm{I}, 203$.

flabelliformis, 21, I63.

fleischeri, 22, 162, 208.

ithacensis, 18,163 .

levis, I63.

minutus, $2 \mathrm{I}, 163$.

mordax, 20, I6I-62, 202.

nelsoni, 21, I63, 203.

quadratus, 163 .

sherwoodi, 22, 162-63.

(Ctenodus) sherwoodi, I62.

uddeni, 16, т6о, 162, 202 .

valenciennesi, I 59 .

Dissodus, 59.

Dittodus, 59.

Doliodus, 6I.

problematicus, I3.

Dollo, cited, I58, I65, I74.

Drepanaspids, $9 \mathrm{I}$.

Drepanaspis, 25, 26.

East Bethany, 15 .

Eastman, C. R., cited, 93, 97, 105.

Eczematolepis, 78. pustulosus, 79.

Eichwald, E. von, cited, 40.

Eifel district, Germany, 66, 69, I00, IOI, I I2, I I 8, I69, I 87, I92.

Eighteen Mile Creek, I4, I5, I7, I8, 57, 58, $71,72,85,86,139,149$.

Elasmobranchii, 23, 27, 54-65.

Elbert formation, 20, 53 .

Elgin, 53, 54.
E11s, R. W., cited, I90.

Elmhurst, Ill., 20, 59, 60, 72.

Encrinal limestone, I5.

? Eriptychius americanus, I2.

Euomphalus bed, I6I.

Euphaneropidae, 23.

Euphanerops longaevus, I6, 3 I.

Eusthenopteron, I64. foordi, I7.

Explanation of plates, 195-224.

Fairport, Ia., І 6, І 6 ı.

Fall creek, 77.

Faunal list showing distribution of Middle Devonic fossil fishes, I93.

Fins, evolution of, 56; paired, development, I 80 ; effective, development of, I82-83.

Franklin, 20, 2I, 22, 69, 70, I39, I62, I69.

Franklin county, O., I9.

Fürbringer, K., cited, I I 5.

Gamphacanthus, 73, 82 .

politus, 82.

Ganoids, I64.

Ganorhynchus beecheri, 21, 22.

Garman, S., cited, 73.

Gaskell, cited, 3I.

Gaspé, Quebec, I3.

Gaspé Devonic, Iş.

Gaspé sandstones, I9̧, I9I ; age, I89.

Gaudry, Albert, quoted, I77-78.

Genera of doubtful family position, I 56-57.

Genesee shale, I7, 64, 7I, I33, I34, I39, I 47, I49, I 72 .

Geneva, I5, I30.

Genundewah, I33.

Genundewa limestone, I34.

Geological conclusions, I83-93.

Glenville, I7, I72.

Glyptaspis, 147 .

abbreviata, I47-49, 220. 
Glyptaspis (continued) verrucosa, I9, $147, \mathrm{I} 48$.

Glyptolaemus, I67.

Glyptolepis quebecensis, I66.

Glyptopomus sayrei, 22.

Goniatite limestone, I7, 72, I29.

Grabau, cited, 72 .

Gyracanthides, 179 .

Gyracanthus, 64, 86-87.

murrayî, 87 .

sherwoodi, 21, 22, 87-88, 20 I.

Haeckel, cited, 88.

Hall, James, cited, I66, I67 ; mentioned, 62. Hamilton limestone, I4, I 5, I6, 61, 62, 68, $69,73,76,80,83,85,86$, I 32, I 39, I 40 , I 57, I 69, I 87, I 88.

Harpacanthus, 66.

Hay, O. P., cited, 30, 59, 64, 9 I.

Heliodus lesleyi, 2 I.

Helodus gibberulus, 20.

Heteracanthus, 73, 82.

politus, I5, I6, I7, 82-83.

uddeni, I5, I6, 83.

Heterodontus, 65.

Heterostraci, 23, 25, 27, 28-30.

High Point, 58, 63.

High Point sandstone, 20, 21, 58, 63, 70 .

Holauchenia, 9I.

Holocephali, 23, 65-88.

Holonema, ${ }_{56}$, 157.

horridum, 2I, I 56 .

rugosa, 50 .

rugosum, 2I, 22, I 56 .

Holopetalichthys novaki, Io2.

Holoptychiidae, 23, I65-68.

Holoptychius, I64, I66, I67.

americanus, 2I, 22, 50, I67, I68, 209.

filosus, 2 I, I 68 .

flabellatus, I 68 .

giganteus, 20, 21, 22, 167 .

granulatus, 2I, I 68 .
Holoptychius (continued)

halli, 22, I68.

latus, 168.

pustulosus, 22, I68.

quebecensis, I7.

radiatus, 22.

serrulatus, 168 .

tuberculatus, 20, 22, 168 .

Homacanthus, 74 .

acinaciformis, $21,75,197$.

gracilis, 13 .

Homosteidae, 23.

Homosteus, 95, 99, I00, 106, I07, I I0.

Hoplonchus parvulus, i8, 75 .

Hudson Bay Middle Devonic fauna, I9I.

Hunsrück slate, 26.

Huron shale, I8, I9.

Hussakof, L., cited, 92, 99, I23, I39, I85.

Huxley, T. H., cited, I64.

Hydraulic limestone, I33.

Ichthyotomi, 23, 58-63.

Ichthyodorulites, 65, 73-88.

Iowa City, 71 .

Ischua, 88.

Isospondyli, I 83 .

Ithaca, $18,77$.

Jaekel, Otto, cited, 3I, 33, 38, 69, 90, 9I, 99, I00, IO2, II4, II 5, I 21, I74, I93.

James Bay, Canada, I4.

Johnson county, Ia., 20, 72, 73, I64.

Jordan, cited, 92-93, I78.

Kayser, E., cited, IOO, IO2.

Kelly's island, Lake Erie, 85.

Kemna, cited, I74.

Kings county, New Brunswick, I2.

Koenen, A. von, cited, IO2.

Labyrinthodonts, I8I, I82.

Lacertilians, I22. 
Lanarkia, 25. spinosa, 25 .

Lankester, E. R., cited, 92.

Leidy, J., cited, I66.

Lepidosiren, 88, 96, 109, I2 I, I 26, I82.

Lepidosirenidae, 23.

Lepidosteus, I82.

Leptolepis, I83.

Leroy, N. Y., I3, I4, I7, 58, 70, 80, 84, I I2, I 8 , I69.

Le Roy, Pa., 2i, 22, i I5, I I6.

Leuckart, cited, 88.

Lexington, Ky., I33, I47, I48, I49, 220.

Liège, Belgium, I 38 .

Lime Creek beds, Ia., 20.

Lime Rock, I 4, 84 .

Liognathus spatulatus, I I 5, I45.

Sce also Coccosteus (Liognathus) spatulatus.

Livingston county, I28, I69.

Livonia, I 5 .

Livonia Salt Shaft, I28.

Logan, Sir William E., cited, I9I.

Lorain county, O., I8, I9.

Louisville, Ky., I 47-9, 220.

Low, cited, I9o.

Lower Carbonic limestone, 62, 75.

Lucas, F. A., cited, 92, 167 .

M'Coy, cited, 89 .

Machaeracanthus, 64, 83, 193.

sp., I 5 .

bohemicus, 86.

longaevus, I4, I 5, 85-86, I99.

major, I4, 85 .

peracutus, $14,84,85$.

sulcatus, I3, I4, 84-85, 86, I9I, 200.

Machaerius, 83 .

Mackenzie, cited, 177 .

Macropetalichthyidae, 23, 99-II3.

Macropetalichthys, 95, 99, Ioo-3, I I2, I I 7, I 22, I 32, I 93 .
Macropetalichthys (continued)

sp., 103, 104.

agassizi, I 12.

manni, IO3.

pruemensis, IOO, IOI-2.

rapheidolabis, I4, IOO, I03-I2, I92, 2I 2, 216.

sullivanti, IO3, I04, I92.

Manitoba, I5, I6.

Manlit1s, I5, I 29.

Mansfield, Pa., 22.

Marcellus shale, I4, I 5, 58 I 29, I 30, I 35 .

Marsh, O. C., mentioned, I 52 .

Meckel, cited, I 54 .

Menaspis, 67.

Mesacanthus, I8I.

Meyer, Hermann von, cited, IOI, IO2.

Milford, O., 85.

Miller, Hugh, mentioned, I77.

Miller, S. A., cited, 59, 78, I 57 .

Milo, I7, 8I.

Milwaukee, Wis., I4, I5, I6, 6I, 62, 69, 73, $80,83,86$, I33, I40, I 57, I69.

Mixer, F. K., mentioned, $57,79,85$, I 34 , I37, 148.

Mollier, S., cited, 56 .

Monocladodus clarki, I8.

pinnatus, 18.

Monroe, Charles E., mentioned, 62.

Moscow shale, I4, 76 .

Mt Morris, I7, I 52, I 56 .

Müller, Johannes, cited, 88.

Mylostoma, 94, 95, 96, 99, I2I, I 42, I495 I, I52, I80; dentition of Neoceratodus and, 97-99.

newberryina, I80.

terrelli, I49.

variabile, I9, 98 , I 49, I 50, I 5 I, I 53, I 54 , I $56,222$.

Mylostomatidae, 23, 99, 149-56.

Mylostomid upper dental plates, 222.

Myriacanthus, 73 . 
Nairn, 53, 54.

Nàples, I7, 20, 21, 58, 63, 70, 72 .

Naples shale, I7. 57, 58, I 56 .

Neoceratodus, 88, 89, 93, 94, 95, 100, I04, 105. 106, 108, I09, IIO, I1 5, I2I, I32, I33, I 49, I58; dentition of Dinichthys and, 96-97; dentition of Mylostoma and, 97-99.

forsteri, I 32 .

New Albany beds, I8, I33.

New Brunswick, 28.

New Buffalo, Ia., I6o.

Newberry, John Strong, cited, 7, 5I, 52, 60, $63,68,75,76,78,79,82,85,87,90,91$. 99, IOI, IO2, I03, I05, IO9, I I I, I I 3, I I 5, I 1 7, I I9, I25. I 38, I4I, I43, I47, I49, I 57, I62, I63, I69.

Niagara beds, I 2, 59, 73 .

Nictaux Falls, N. S., I3.

North Evans, 17.

North Liberty, Ia., 74, I61, I62.

North Walton, 74.

Norwood, cited, I00, I02.

Nova Scotia, 13.

Oesel, 40.

Oestophorus, I 57.

Old Red sandstone, 26, 29, I 59, I64, x66, I7I, I77, 189; upper, 53.

Olean, 88.

Olean conglomerate, 21, 77 .

Onchus, 73.

$s p ., \mathrm{I} 2$.

clintoni, I2, 73 .

pennsylvanicus, 12,73 .

rectus, 22, 74 .

Oneonta beds, 17, I32, I33, I39.

Onondaga fish fauna, origin, I9I.

Onondaga group, 30 .

Onondaga limestone, 9, 13, 14, 70, 79, 84, $85,112,113,115,118,169,187,188$.

Onychodontidae, 23, I68-69.
Onychodus, I64, I68, I69, I93.

sp., I6, I96.

hopkinsi, I69, 197, 200, 212.

ortoni, 19.

sigmoides, I4, 16, 168, 169, I96, 200.

Oracanthus, 78 .

abbreviatus, 79 .

fragilis, 79 .

granulatus, 79 .

Oran, 15, I69.

Oriskany sandstone, I3.

Orodus, 75 .

elegantulus, $\mathbf{1} 8$.

Osteolepis, 167.

Osteostraci, 23, 27, 28, 3 I.

Ostracoderms, 90, I80.

Ostracophori, 23, 24-54, 90, 95, III, I48, I79. I80.

Owen, cited, IOO, IO2, I64.

Oxford, 17, 133, I39.

Paired fins, of Cladoselache, 56 ; dawn oi, I80-8I ; as paddles, I8I-82.

Palaeaspis americana, $\mathbf{I} 2$. bitruncata, 29.

elliptica, 29. sericea, 29.

Palaeomylus, 66, 67, 73, I49, I93.

crassus, I 3 .

frangens, I 3 .

greenei, $15,153$.

Palaeoniscidae, 23, I70, I71-72.

Palaeoniscus ? antiquus, I8, I7 I. ?devonicus, I7, I7I.

? reticulatus, I8, I7 1 .

Palenville, I39.

Paleoniscid fishes, 165.

Palaeaspis, 27, 28. americana, 29-30.

Pander, C. H., cited, 36, 40, II4, I57, 164.

Parker, cited, 158. 
Parrish limestone, I7, 72.

Patten, William, acknowledgments to, 34 ; cited, $26,30,3 \mathrm{I}, 33,36,40,44,45,46$, 47-49.

Perry county, Pa., I2, 28, 30 .

Phacops rana, 85 .

Phaneropleuridae, 23.

Phaneropleuron, 95.

Phlyctaenacanthus, 79, 80. telleri, I5, 8o.

Phlyctaenaspis, I I5, II7. acadica, I3.

Phoebodus, 6o-6r. politus, I8, 60-6I, 197 .

Pholidophorus, 183 .

Phyllolepis, I 56, I 57. delicatula, 2I, I 57.

Physichthys, Ior.

hoeninghausii, IOI, II2.

Physonemus, 82 .

Pierce, John, mentioned, I52.

Pisces, I2, I3-I6, I6-I9, 20, 22, 23, 54-I72.

Placodermata, 90, 95.

Placodermi, 27, 78, 89, 91, 92.

Placothorax, Io2. agassizi, IOI, II2.

Plates, explanation of, 195-224.

Plato, quoted, 93.

Platysomatidae, 23.

Platysomidae, I70.

Pleuracanthid sharks, 95 .

Pleuracanthidae, 23, 58-6r.

Pleuracanthus, 56.

Pleuropterygii, 23, 54-58.

Polyodontidae, I 7 I.

Polypterus, I82.

Polyrhizodus modestus, I8.

Port Jackson shark, 65 .

Portage beds, I7, I8, 57, 58, 64, 72, 81, 82, 83,94, I 34, I 37, I 47, I 48, I 49, I 52, I 56 , I69, I7 I

Portville, 88.
Powell county, Ky., I9.

Pristacanthus vetustus, $8 \mathrm{I}$.

Prosser, Charles S., cited, 9, I39.

Protitanichthys, I44, I 45. fossatus, I9, I44-47, 214.

Protodus, 6r. jexi, I3.

Protopterus, 88, 90, 9I, 96, 97, I21, I 26, I49, I82.

Protospondyli, I82, 183 .

? Psammodus antiquus, I3.

Psammosteidae, 23.

Psammosteus, 78 .

Pteraspidae, 23, 90.

Pteraspis, 26, 27, I67. rostrata, 29.

Pterichthyidae, 32.

Pterichthys, 27, 28, 32, 34-39, I I I I63, I67. (Bothriolepis) canadensis, 43.

elegans, 40.

harderi, 40.

major, 53-54.

milleri, 34, 35 .

striatus, 40.

testudinaris, 32.

Ptyctodontidae, 23, 67-73.

Ptyctodonts, I92.

Ptyctodus, 66, 67, 70, 193.

sp., I7.

calceolus, I5, I6, I7, 20, 71-72.

compressus, 20, 72 .

ferox, I5, I6, 20, 72-73, 82 .

punctatus, 13,70 .

Ramphodus, 69.

Rathbun, Richard, mentioned, 77 .

Regan, C. Tate, cited, 27, 67, 9I.

Rhadinichthys, I7I, I72. $s p ., 203.2 \mathrm{I} 2$.

Rhinestreet shale, I7, I8, 64, I34, I37.

Rhipidistia, 23.

Rhizodontidae, 23, I68. 
Rhizodonts, I67.

Rhynchodus, 66, 67-70, 73, 149, 193 .

sp., I 5, I6, 21, 70, 196.

excavatus, I5, I6, 68-69.

major, 69.

occidentalis, 68.

pertenuis, 20, 69-70, I98.

secans, I 3, 67-68.

Ringueberg, E. N. S., cited, I34.

Rinodus calceolus, 7 I.

Rock Island, I11., r6.

Rockwood, Col., 20, 54 .

Rocky river, O., I8.

Sagenodus, I6o.

sp., 197.

pertenuis, 97 .

St John, Orestes, mentioned, 69.

Salem limestone, 62.

Salina beds, $12,28,3^{0}$.

Sandusky, O., 85 .

Sauripteris taylori, 22, 164, 166.

Scaumenac bay, Quebec, I6, I7, 31, 49, I90, I9I.

Scaumenacia, 95. curta, I7.

Schuchert, Charles, acknowledgments to, I 2 ; cited, I85, I88, I9I, 192 ; mentioned, I 52.

Schultze, L., mentioned, ror.

Scombroids, I83.

Selachii, 23, 64-65.

Selenosteidae, 99 .

Selenosteus kepleri, 19.

Semon, R., cited, 98.

Seneca county, I49.

Sharks, 64.

Sheffield, O., I8, I9.

Sirenodei, 23, 88, 89, IO4, I I3, I 59.

Skates, 64.

Sparta, I7, I8, 64, I7I.

Sphenophorus $s p$., I6.
Sphenophorus (continued)

lilleyi, 2I, I 57.

Spirifer mucronatus, 85 .

Spitzbergen, I18, 193.

Slate Quarry beds, Iュ., 20, 71, 72, 73, 83, I6I, I62, I64.

Stegocephalians, I05, I 22.

Stenacanthus nitidus, 50.

Stenognathus corrugatus, 19.

Stenosteus glaber, I9.

Stethacanthus, 80, 82.

Strepsodus $s p$., 2 I.

Sturgeon Point, I7, I34, 137, 148, 156.

Sturgeons, I 7 r.

Styliola limestone, I33, I34.

Sullivant, Joseph, mentioned, Ioo.

Susquehanna river, 22.

Sweetland Creek beds, Ia., 20.

Synthetodus, 99.

trisulcatus, 20.

Systematic account of Devonic fishes principally from New York and Pennsylvania, 24-I72.

Systematic descriptions, tabular key to, 23 .

Tabular key to systematic descriptions, 23.

Tamiobatis, 65 . vetustus, I9.

Teleostomi, 23, 27, 90, 9I, 92, I64-65.

Teller, Edgar E., mentioned, $7 \mathrm{x}$.

Temnauchenia, 9I.

Thelodus, I 3,25 . scoticus, 25.

Tioga county, Pa., 22, 51, 87, 88, I62, I63.

Titanichthys, 95, I I 4, I 26, I36, 140-44, I 45, I 47 .

sp., I9.

agassizi, I9, I42, I43.

attenuatus, I9.

brevis, I9, 136 .

clarki, I9, I4I, I42, I43. 
Titanichthys (continued) rectus, I9.

Trachosteus, 148 . clarki, I9.

Traquair, Ramsey H., cited, 26, 27, 33, 44, 54, 90, 92, I IO, I I 4, I I 8, I 57, I64, I65, 172; acknowledgments to, 33 .

Tremataspidae, 23, 90 .

Tremataspis, 3 .

Truxton Corners, 80.

Tucker, cited, I75-76.

Tully limestone, I7.

Udden, J. A., cited, I60.

Uronemus, 95.

Valois, I48.

Warren, Pa., 20, $2 \mathrm{I}, 22,63,75,87$, I38, 172. Warren county, $\mathrm{Pa}$., $77,{ }_{138}$.

Waterloo, Ia., I6, 83 .
Waterways, conceptual, $x 89$.

Waverly, Ia., 16, 68, 83.

Waverly beds, 57,75 .

Weller, Stuart, cited, 59, 60, 185 .

Wellsville, I68.

Whiteaves, J. F., cited, 36, 45, I 57, I66, I7I, 19I, 192.

Wiedersheim, R., cited, 126.

Williams, H. S., cited, I 56, I63, I68, 186.

Williams, H. U., mentioned, 79, I 7 I.

Woodward, Arthur Smith, cited, 35, 36, $43,49,51,54-55,56,57-58,64,65,74,78$, $86-87,89,90,92,93$, гог, І І 3, г 23,165 , I66, I67, I 78, I 79, I80, I9r.

Xenodus herzeri, I8.

Yates county, $x 4,76$.

Zittel, cited, 91, I 16, I78.

Zoological conclusions, $178-83$. 








